\title{
Kenya: Poverty Reduction Strategy Paper
}

Poverty Reduction Strategy Papers (PRSPs) are prepared by member countries in broad consultation with stakeholders and development partners, including the staffs of the World Bank and the IMF. Updated every three years with annual progress reports, they describe the country's macroeconomic, structural, and social policies in support of growth and poverty reduction, as well as associated external financing needs and major sources of financing. This country document for Kenya, dated March 12, 2004, is being made available on the IMF website by agreement with the member country as a service to users of the IMF website.

To assist the IMF in evaluating the publication policy, reader comments are invited and may be sent by e-mail to publicationpolicy@imf.org.

Copies of this report are available to the public from

International Monetary Fund • Publication Services

$70019^{\text {th }}$ Street, N.W. $\bullet$ Washington, D.C. 20431

Telephone: (202) 623-7430 • Telefax: (202) 623-7201

E-mail: publications@imf.org • Internet: http://www.imf.org

Price: $\$ 15.00$ a copy

\section{International Monetary Fund}

Washington, D.C. 



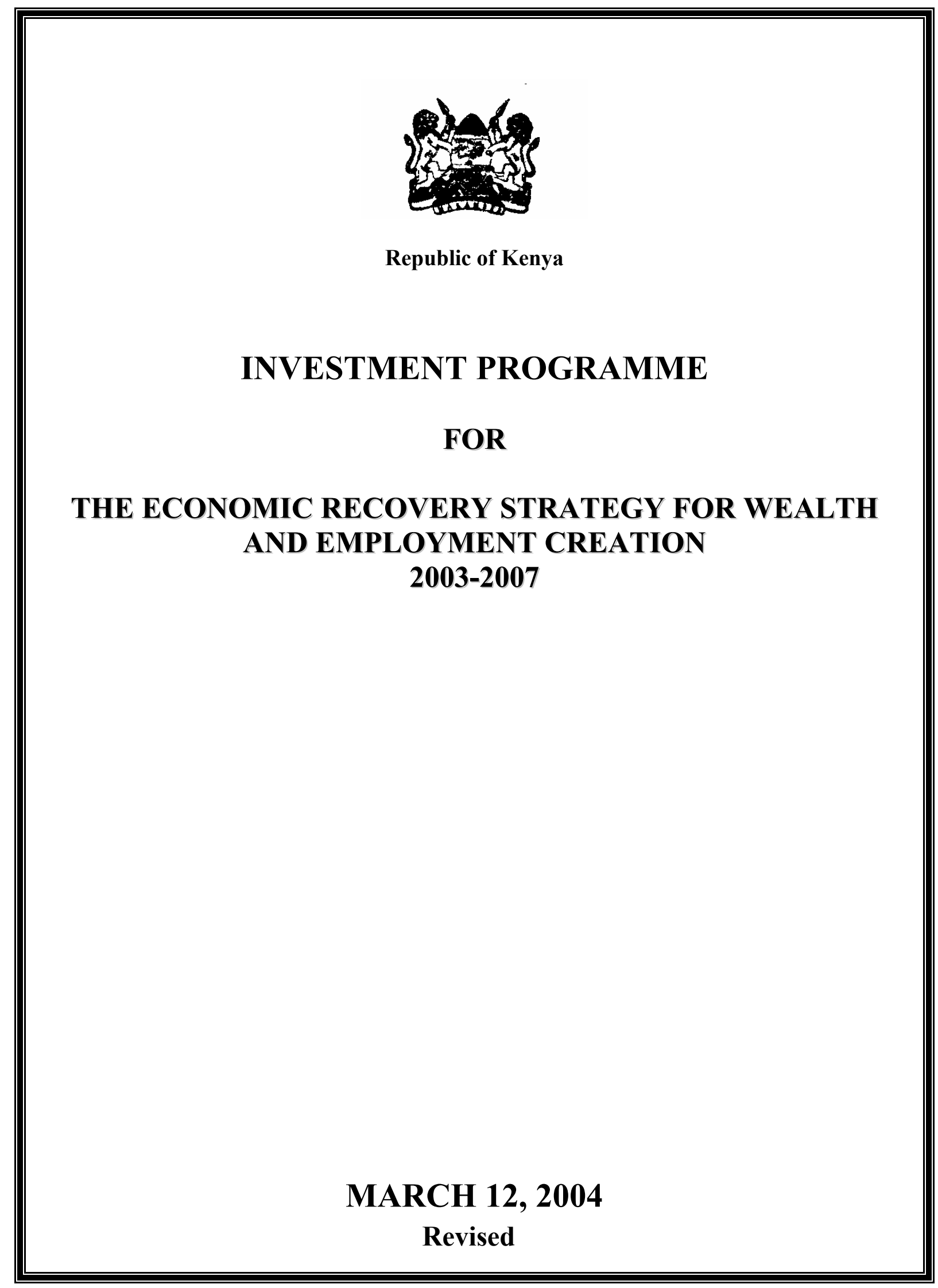


Executive Summary ..................................................................................................................................... v

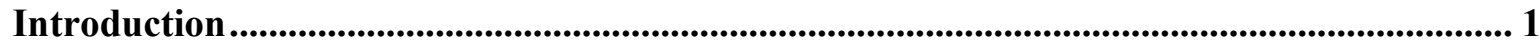

Chapter 1: The Consultation and Institutional Processes for the Economic Recovery

Strategy

Chapter 2: Situational Analysis of the Economy and Poverty in Kenya .................................. 8

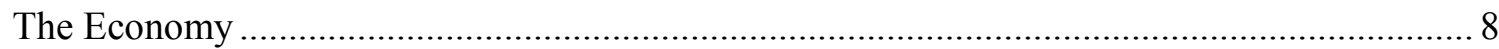

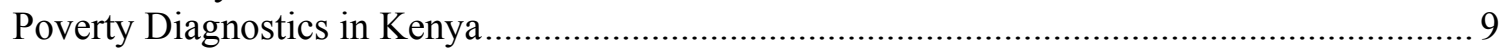

Chapter 3: Economic Growth ....................................................................................... 12

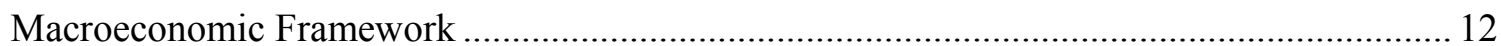

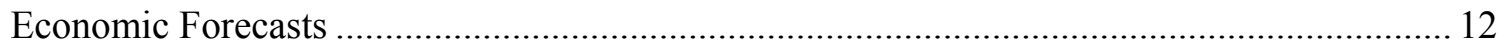

Table 3.1: Forecasts for key economic parameters......................................................... 13

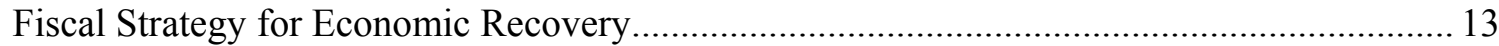

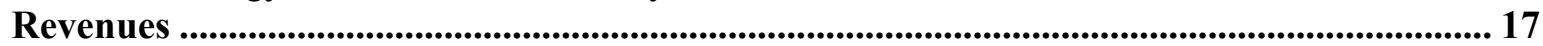

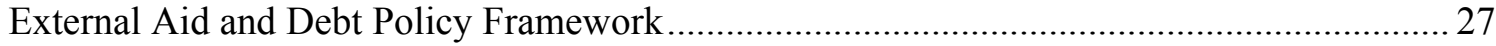

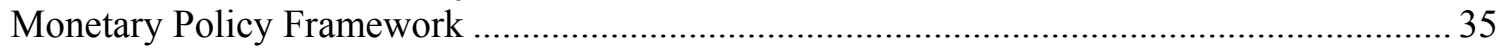

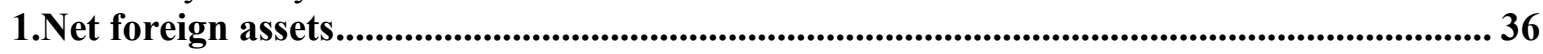

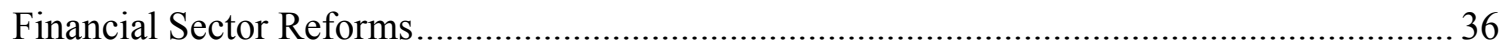

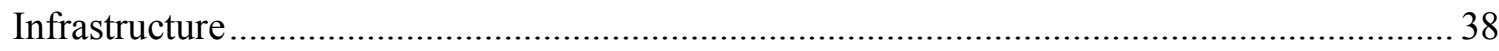

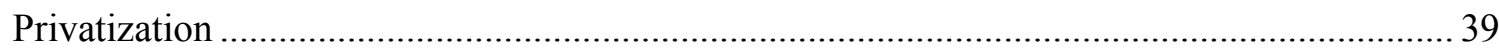

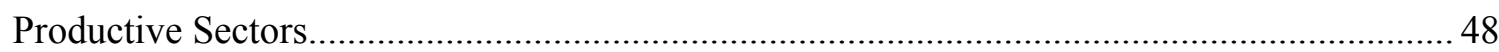

Chapter 4: Equity and Poverty Reduction ........................................................................................ 51

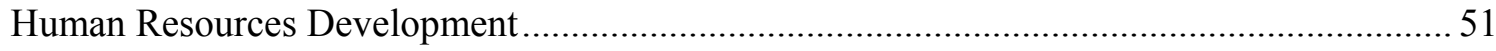

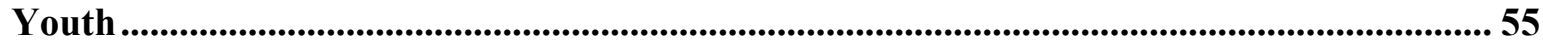

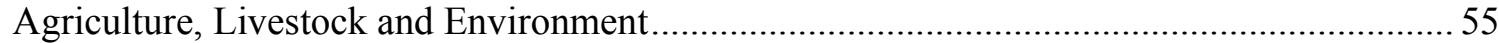

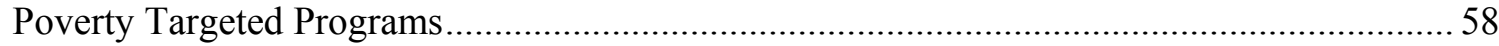

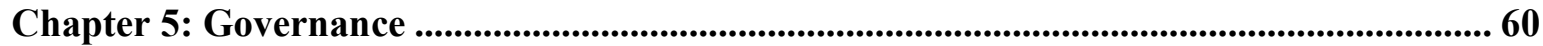

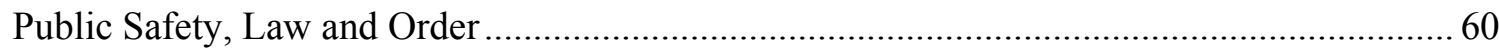

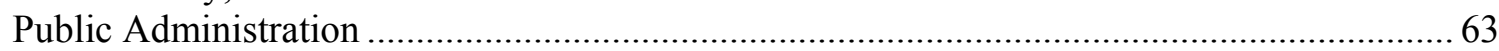

Chapter 6: Financing Framework.................................................................................65

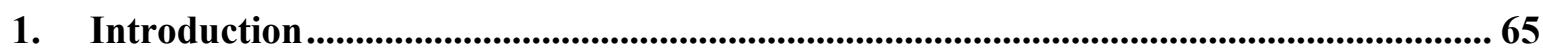

Chapter 7: Monitoring \& Evaluation and National Statistics .......................................... 67

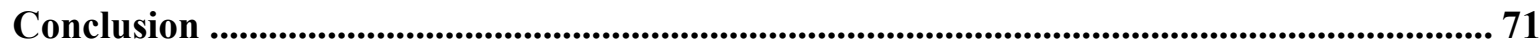

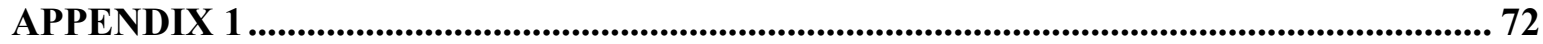

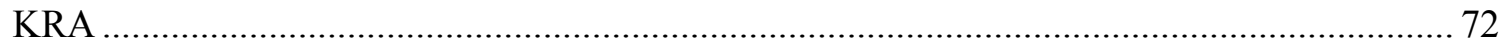

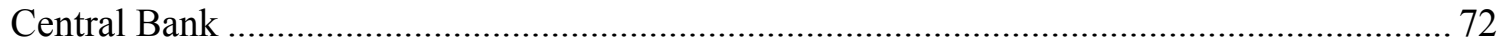

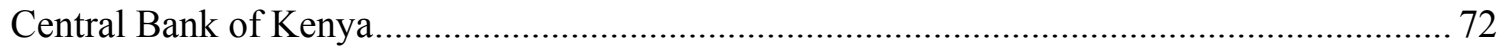

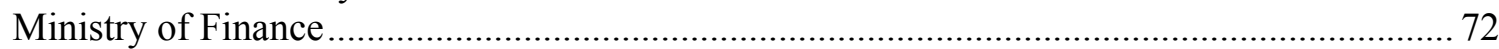

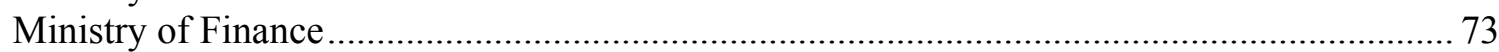

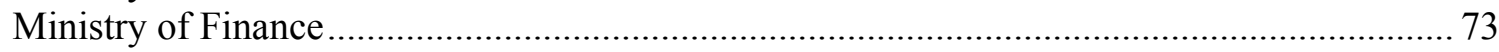

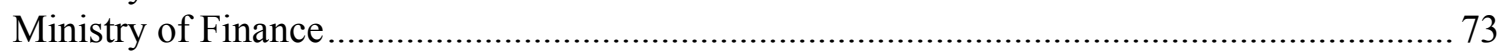

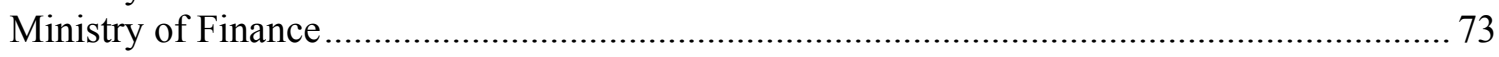

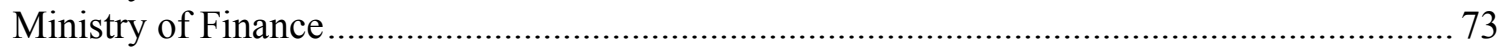




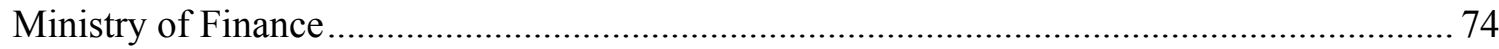

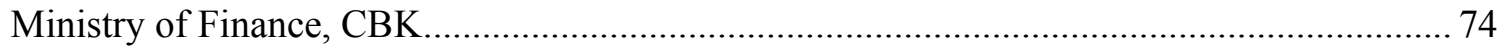

Ministry of Finance, CBK, Ministry of Trade and Industry ........................................... 74

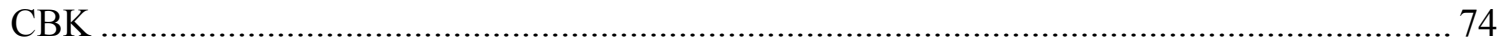

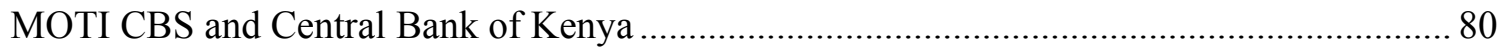

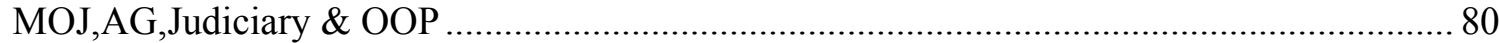

OOP

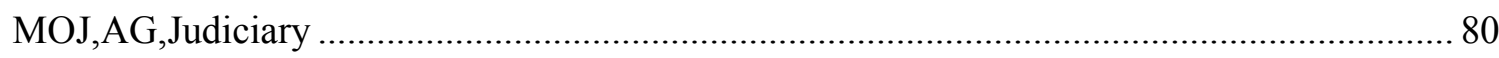

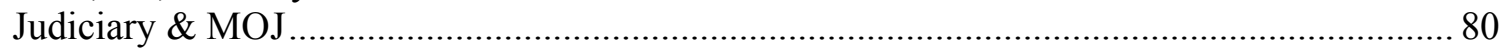

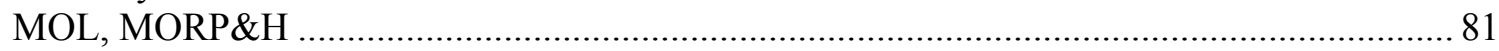

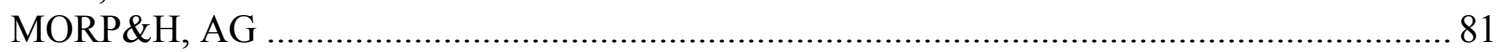

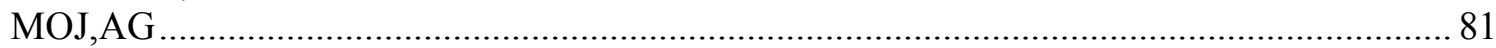

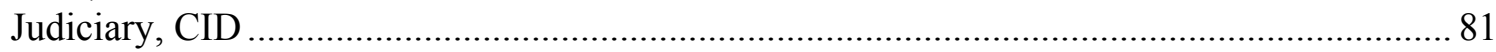

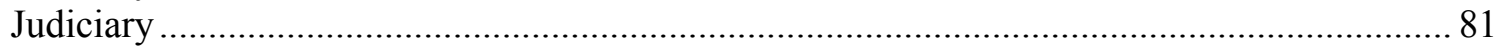

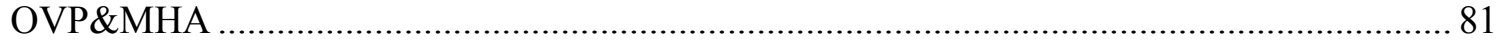

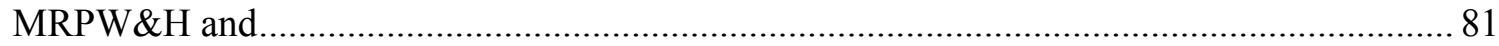

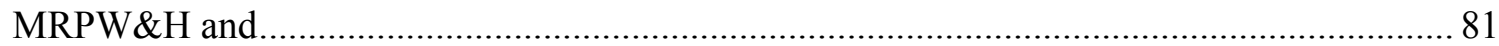

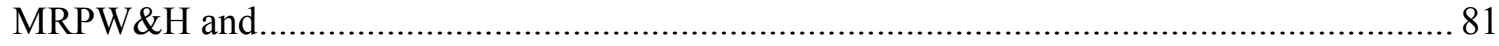

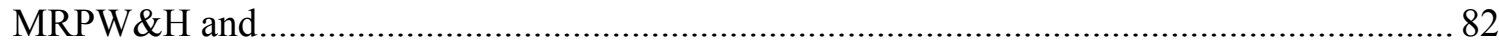

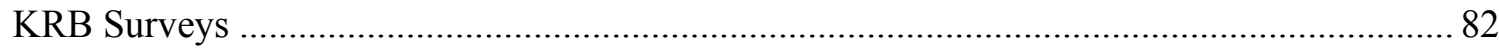

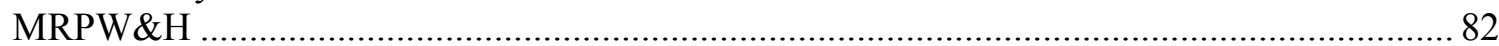

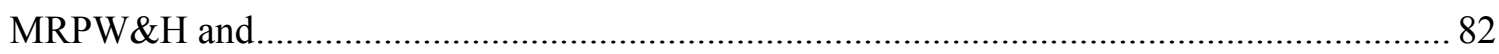

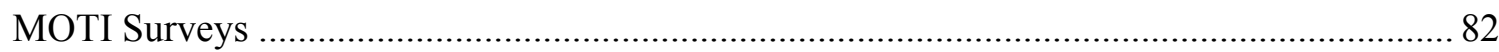

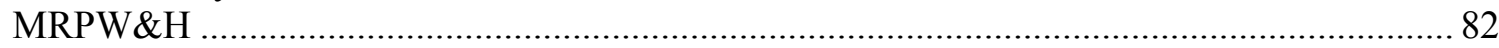

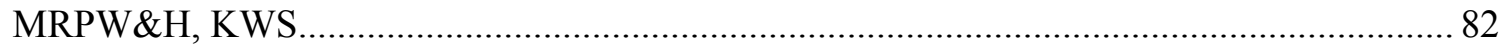

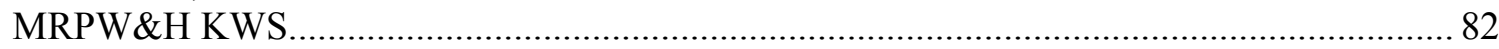

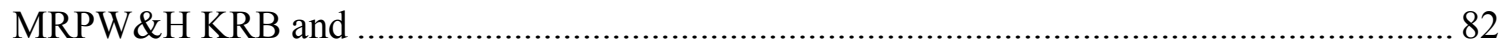

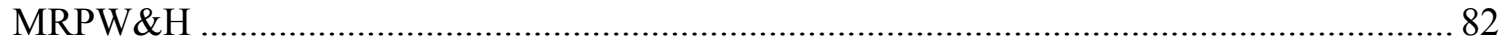

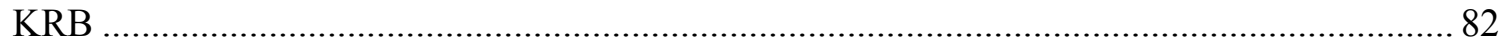

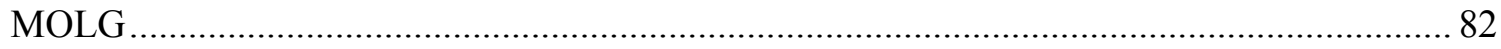

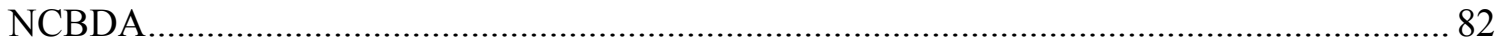

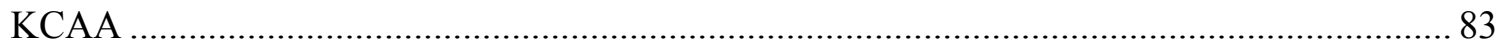

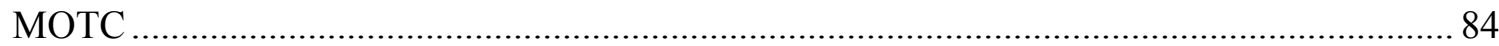

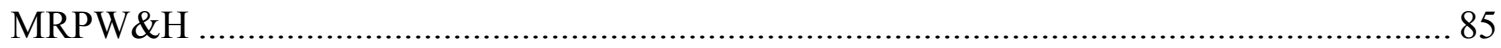

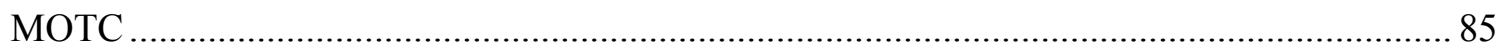

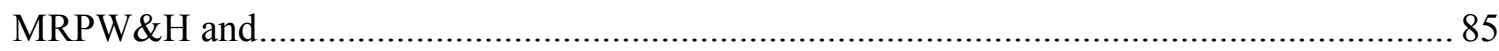

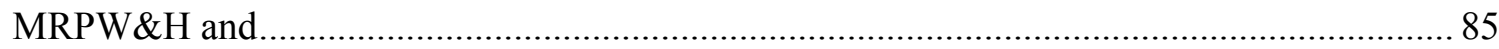

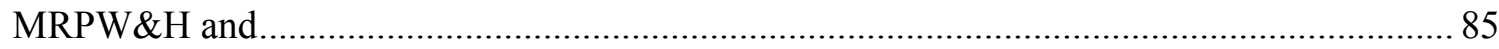

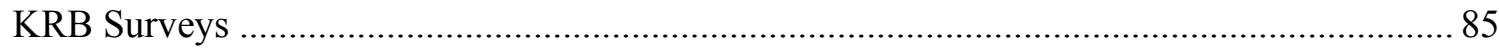

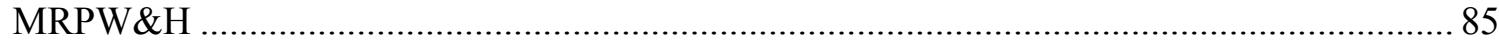

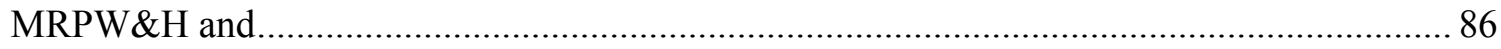

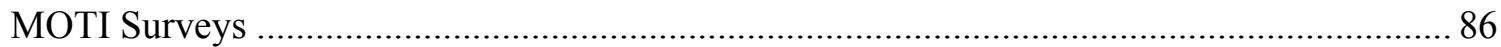

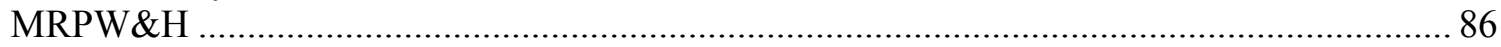

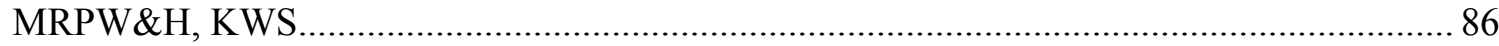

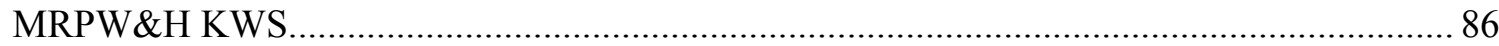

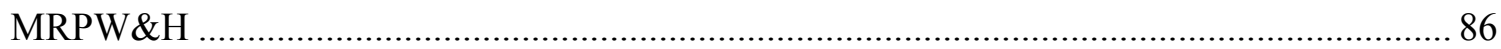

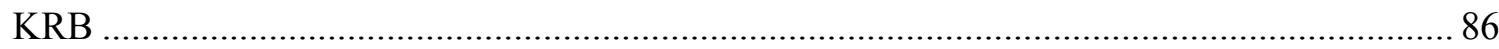

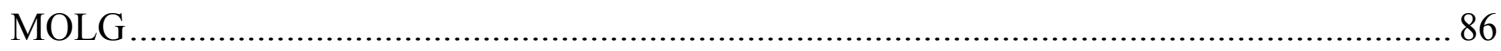

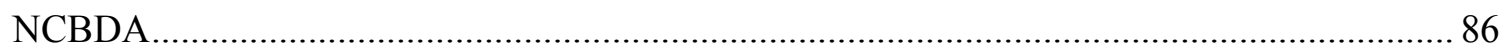

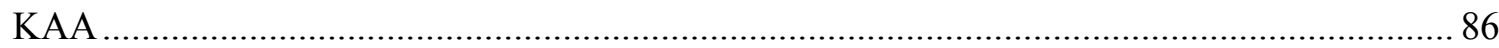


KCAA

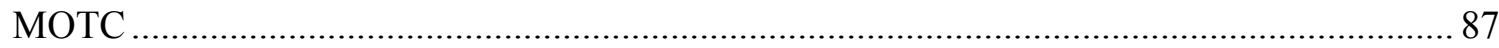

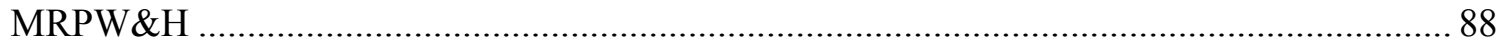

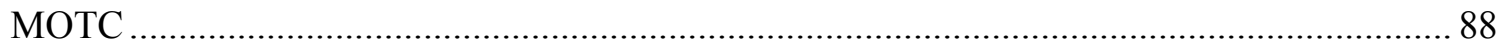

MOTC

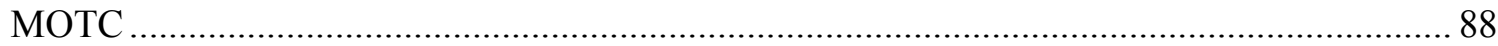

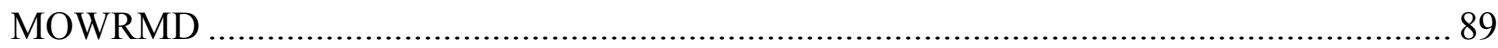

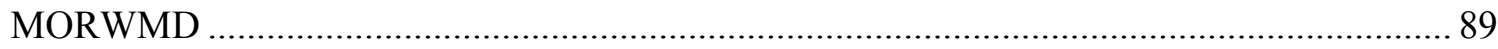

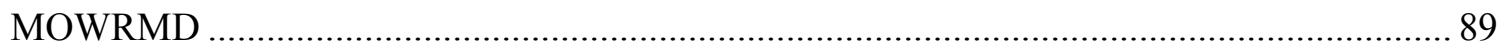

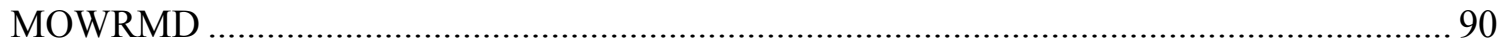

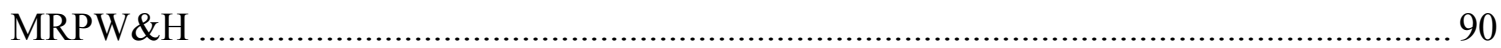

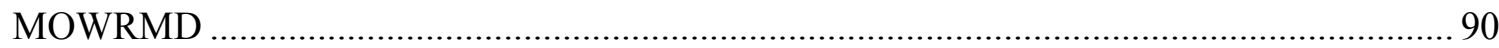

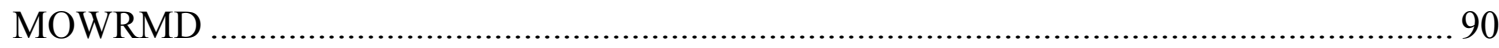

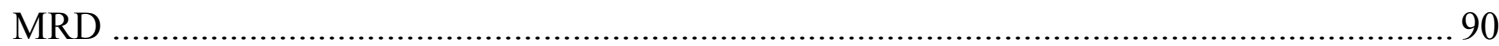

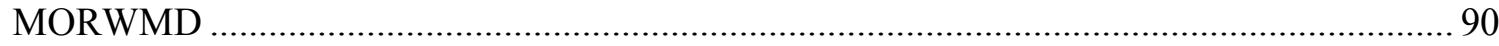

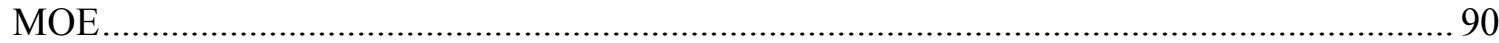

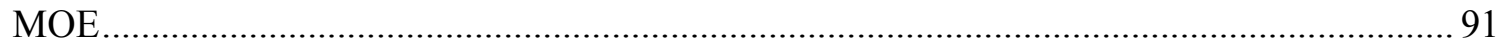

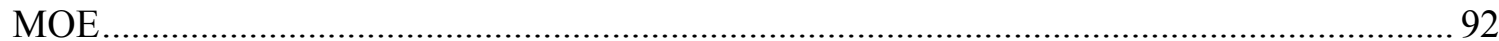

MOE

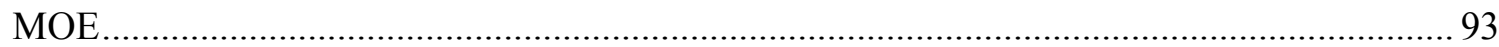

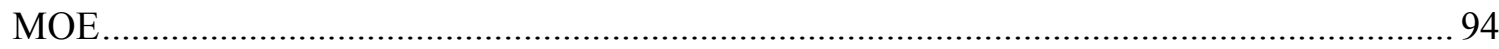

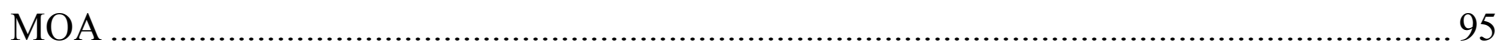

MOA, CBS, OOP

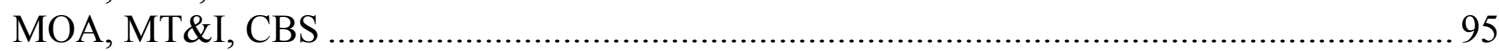

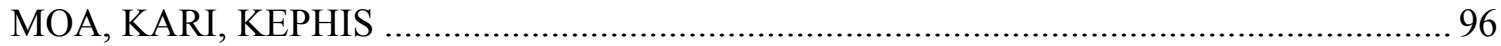

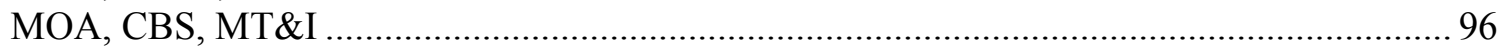

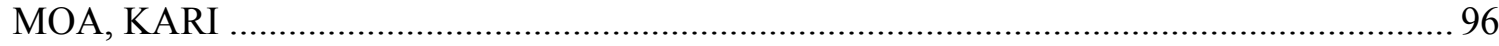

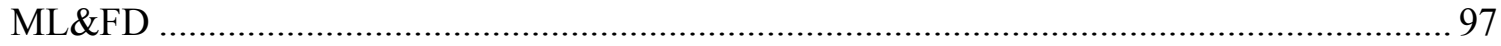

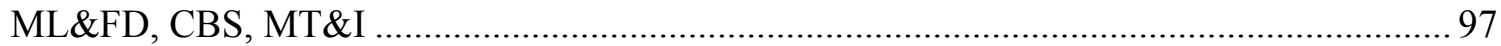

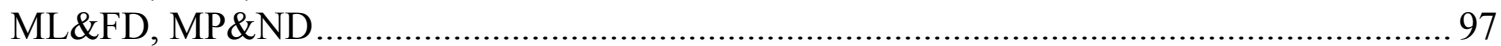

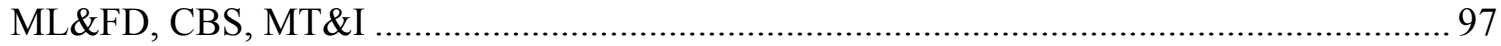

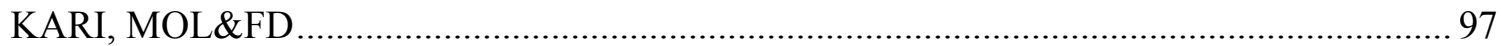

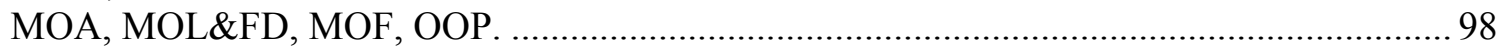

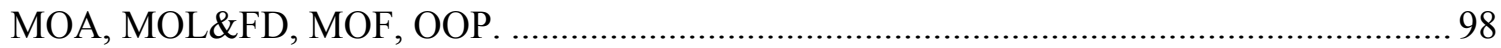

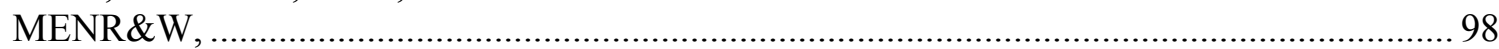

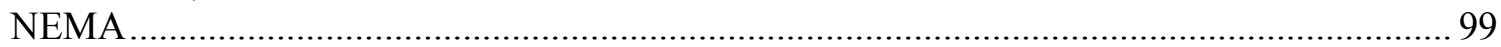

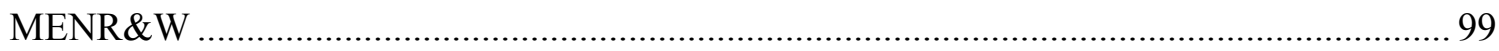

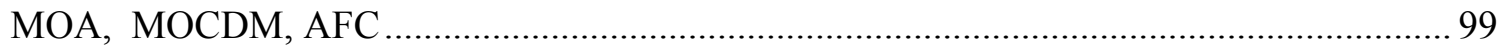

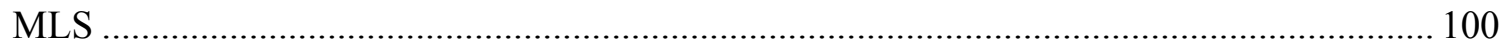

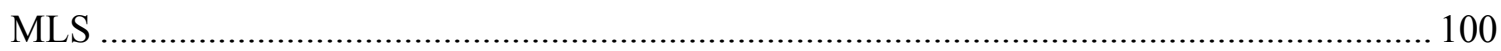

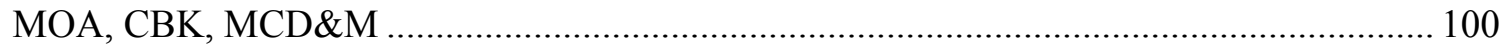

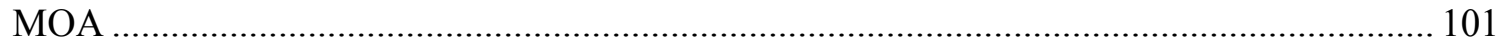

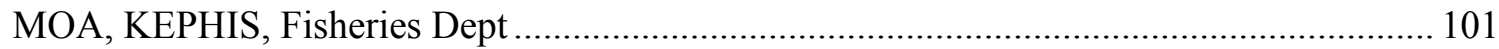

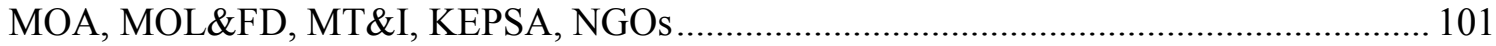




\section{Executive Summary}

This document presents a result-based programme of priority government actions designed to meet the medium-term objectives of the Economic Recovery Strategy for Wealth and Employment Creation or the Economic Recovery Strategy (ERS). To address the economic growth objective, the programme envisages a strengthening of the macroeconomic framework, a more responsible fiscal stance, and the unleashing of private sector participation and investment. To improve equity and reduce poverty, the program focuses on universal primary education, improved access to basic health, expanded productive capacity in agriculture, development of the hitherto overlooked arid and semi-arid areas, and upgrading the living conditions for urban dwellers that have suffered from poor urban infrastructure and social services mainly due to high urbanization rates. To enhance governance, the program proposes far reaching reform of the judiciary, strengthening of rule of law and security, and implementing reforms in public administration systems that are critical to improving government transparency and accountability.

As part of the programme, the government commits its resources and efforts in the achievement of the Millennium Development Goals and an additional set of outcome indicators, as well as input, output and process indicators, related to economic growth, poverty, education, health, and water, among others. The logframe matrix for the ERS, included in this document, spells out the list of indicators and related targets. A summary matrix specifies key developmental targets that are considered major step stones in the developmental process. The activities referred to in this proposal are all key activities to ensure the achievement of these targets.

In revising the ERS, the Government has sought to ensure that the investment programme can be funded in a sustainable manner. Consequently, the ERS investment activities have been reprioritised, bringing the implementation cost down from Kshs 706 billion as originally indicated in the interim investment programme to Kshs 340 billion. The financing framework has also taken account of donor pledges during the Consultative Group meeting which totalled US\$4.1 billion. With the revisions, the financing gap for the ERS declines to Kshs 58.5 billion, which can be accommodated through a 7.5 percent reduction in non-ERS priority activities. The revised strategy is thus fundable. 



\section{Introduction}

This investment programme presents a set of priorities of government actions designed to meet the medium-term objectives of the Economic Recovery Strategy. The ERS presents a multifaceted strategy to meet economic growth, equity and poverty reduction, and governance objectives. To spur economic growth, the ERS commits to strengthening the macroeconomic framework, assuming a responsible fiscal stance, and providing a conducive environment for private sector investment in the productive sectors and, specifically, in infrastructure development and maintenance. To reduce poverty, ERS focuses on universal primary education, improved access to basic health, development of traditionally overlooked arid and semi-arid areas, and upgrading the living conditions for the urban poor. To enhance governance, ERS proposes a far reaching reform of the judiciary, strengthening of rule of law and security, and implementing reforms in public administration systems that are critical to improving government transparency and accountability.

The investment programme operationalizes the intentions of the ERS by spelling out priority programs, identifying key activities within each program, providing budgetary estimates and financing gaps within the overall resource envelop, laying out the implementation timetable, and committing to a set of monitorable targets. The interim version of the investment programme was tabled for discussion by H.E. the President during a National Investment Conference on $20^{\text {th }}$ November 2003. Thereafter, it was tabled for discussion at the Donors' Consultative Group meeting held on $25^{\text {th }}$ November 2003. Following the national conference and the CG meeting, the Government embarked on producing this final version of the investment programme by updating the interim version. The updated investment programme:

(i) incorporates the outcomes of the Consultative Group meeting;

(ii) incorporates the Government commitments entered into for the PRGF;

(iii) brings on-board and takes cognisance of new issues and developments that have taken place since the publication of the original ERS and interim investment programme such as the rescheduling of Kenya's external debt; and

(iv) Adopts a more realistic costing framework given the donor pledges in the CG and the macroeconomic framework of the PRGF.

This updating was necessary because in addition to the need to have the investment programme consistent with the outcomes of the CG meeting and the PRGF commitments, the interim investment programme of ERS was found to be inadequate on several fronts. Firstly, it failed to describe the process that will be followed to ensure that the MTEF and the budgetary allocations are aligned with the priorities of the ERS. Secondly, it failed to describe the arrangements through which coordination of the ministries of planning, finance, line ministries, and development partners will be enhanced. And finally, the monitoring and evaluation framework of the investment programme was incomplete. These shortcomings were addressed as follows in this investment programme:

(i) The sectoral activities have been reprioritised;

(ii) The costing of the new priorities has been revised;

(iii) The outcomes of the Consultative Group meeting have been incorporated;

(iv) The Ministerial Public Expenditure Reviews (MPERs) were utilised as core inputs to the prioritisation process; 
(v) Revisions dealing with poverty diagnostics as contained in the more detailed poverty maps and the Kenya Demographic and Health Survey; the coordination mechanisms of the MTEF; and the consultation process have been incorporated;

(vi) The logical framework matrix was also revised to make it a more complete instrument for monitoring and evaluation; and

(vii) A new matrix of the investment programme that is consistent with the MTEF budgeting definitions was introduced as the new Annex II.

The document is organized as follows. The introductory chapter describes the ERS consultation process and the coordination mechanisms for implementation. Chapter 2 is the scene setter presenting current economic conditions in the country including poverty assessment. Chapters 35 present the government program, one for each major objective of the ERS: Economic growth, Equity \& Poverty reduction, and Governance. Chapter 3, on economic growth, focuses on the macroeconomic framework, infrastructure and productive sectors. Chapter 4 presents human resource development, agriculture and rural development, and poverty targeted programs. Chapter 5, on governance, lays out the reforms required to strengthen the rule of law and to improve transparency and accountability of public administration. Financing framework is presented in chapter 6 . The monitoring and evaluation framework is described in Chapter 7. A monitorable and output-based ERS logical framework matrix is presented in Annex I, which identifies input, output and outcome indicators, and monitoring mechanisms. The logical framework matrix starts with summary which identifies 15 major developmental outcomes of the ERS and selected indicators and targets, among which are the Millennium Development Goals. Annex II is a matrix providing the objectives, outcomes, costs, and enabling activities under each of the MTEF sectors. 
Chapter 1: The Consultation and Institutional Processes for the Economic Recovery Strategy

\section{The Process}

The Government of Kenya subscribed to the Poverty Reduction and Growth Facility (PRGF) in 2000 and embarked on the preparation of the Poverty Reduction Strategy Paper (PRSP) at the same time. This preparation was undertaken through wide-ranging consultations and dialogue in order to build consensus on priority actions and activities necessary for economic growth and poverty reduction. The PRSP was preceded by the Interim Poverty Reduction Strategy Paper (IPRSP) released in 2001. The IPRSP only involved limited consultations at the national level. The PRSP consultations followed a three-tier approach: national, provincial and district levels. The stakeholders in the consultations included the Private Sector, Civil Society, the Development Partners and local communities. A national steering committee that included all the stakeholders was formed to spearhead the process and ensure inclusion at all levels.

The consultations also covered thematic areas to take care of important issues that are cross cutting and which tend to be left out in mainstream sector working groups. The consultations went as far down to the divisions, locations and villages in some of the districts. Participatory Poverty Assessments (PPA) were carried out in ten (10) sampled districts. The District PRSP reports and PPA reports together with inputs from the Sector Working Groups were synthesized into the PRSP (2001-2004). The PRSP formed the basis for the 2002/03 budget.

In December 2002, a new government under the National Rainbow Coalition (NARC) took office and immediately embarked on the process of preparing an economic recovery strategy, focusing on reviving the economy and creating employment. The ERS presents a road map for economic recovery during the next five years. The ERS takes into account existing Government policy documents, particularly the PRSP and NARC's Manifesto and Post-Election Action Plan.

The development of ERS was also a result of wide-ranging consultations with stakeholders. The stakeholders included, parliamentarians; trade unions; professionals; financial institutions; industrialists; ASALs; Development Partners; Civil society and government. The strategy therefore embodies the views and aspirations of all Kenyans.

Based on the ERS, an Interim Investment Programme was developed. The Interim Investment Programme provides a framework for implementing the ERS. The Interim Investment Programme was discussed at a National Investment Conference in November 2003, organized jointly by the government and the private sector. At this conference the private sector committed itself to continued partnership with the government for the success of the programme. It was also the Investment Programme that formed the basis of discussions at the Donor Consultative Group meeting held in November 2003. A prioritization workshop was also held in January 2004 where all the activities in the logical framework of the programme were prioritized in line with the sector objectives. During the same workshop, the Rapid Result Initiative (RRI) was launched in one of the sectors. Comments by the development partners, other stakeholders and inputs from the National Investment Conference, the Donor Consultative Group meeting and the prioritization workshops has be used to generate this final version of the Investment Programme. 


\section{Mechanisms of Linking the Ministerial Public Expenditure Reviews to the MTEF Budget Process}

A key priority of the MTEF process is to improve the planning and resource allocation process to achieve a more effective use of resources and to redirect available resources towards implementation of policy priorities. The MTEF is an outcome based planning and budgeting process that seeks to establish an explicit link between policy, planning and budgeting. More importantly, the MTEF objective is to strengthen the linkage between the annual budget and national development policies and provide means of aligning expenditures to national priorities, outputs and outcomes set in the Economic Recovery Strategy. This way the National Budget will be guided by national objectives and the desired outcomes.

A review of the existing policies, analysis of the ministerial expenditure trends and the impacts of programmes and activities financed through the MTEF process is what is widely referred to as Public Expenditure Reviews (PER), and generally used to review and analyse trends and impacts of these expenditures.

The PER process in Kenya is implemented through an established institutional framework led by the National Steering Committee of Permanent Secretaries, Technical Officers in all the line Ministries and representatives of Development Partners. The Steering Committee is responsible for policy on PER and is chaired by the Permanent Secretary, Ministry of Planning and National Development and co-chaired by the Country Director World Bank Kenya office. The Steering Committee is supported by a Technical Working Group (TWG) drawn from all the ministries and representatives of key Development Partners under the leadership of the Ministry of Planning and National Development and is responsible for all the analytical work on PER and the back stopping roles form ministerial public expenditure reviews. The TWG is supported by a Secretariat, which has been modeled along the sector wide approach used in the MTEF process.

The outputs of PER are used in preparing reports of the Sector Working Groups (SWG) which are responsible for the coordination of MTEF sector policies, priorities and activities. Future institutional reforms for PER will entail the introduction of Public Expenditure Tracking Surveys (PETS) which have been piloted in the Ministries of Health and Education Science and Technology.

The government, having recognized that public expenditure reviews are an integral part of the MTEF process issued one circular that is going to guide the MTEF process for the period 2004/05 - 2006/07 and the Ministerial Public Expenditure Reviews (MPERs). The MPERs will review the past trends of expenditures including those expenditures that are related to core poverty programmes or social spending. The MPER reports will also include costed programmes and activities. The costed programmes and activities must be in line with those identified in the Investment Programme. Having costed the programmes, they will draw a three year financial/financing plan for the Ministry.

While the work of the sectors and Ministries is going on, the macro working group will draw up a fiscal strategy which will state the resources available and based on the ERS and the Investment Programme indicate which sectors are going to support faster recovery needed for poverty reduction.

The sector resource envelopes will be developed after having reviewed sector needs as given in the SWG reports and after having matched those needs with the Fiscal Strategy Paper (FSP) and 
other policies. Once sector envelopes are approved by cabinet, ministries will participate in the sharing of the resources through a criteria which must be seen to support the overall National goals/strategies as will be outlined in the fiscal strategy. Thereafter the Ministries will prepare their itemized budget according to resources they will get from the sectors.

A review of the MTEF process is in its final stages of completion. The main thrust of the review is to determine the main strengths and weaknesses of the current MTEF budget process and make recommendations for better public expenditure management. Together with the MTEF Review Report will be detailed implementation action plan with definite time lines that will pave the way for a revised MTEF for Kenya.

\section{Coordination Arrangements for the Implementation of the Economic Recovery Strategy}

\section{ERS Implementation Coordination}

The development of the ERS and the Interim Investment Programme involved inputs from ministries of Planning and National Development, Finance, line ministries, development partners, the private sector and civil society. The inputs were received through consultative meetings, workshops and conferences, correspondences and missions. This all- inclusive spirit should be advanced to the implementation of the ERS. This requires that an elaborate mechanism be put in place to provide an interactive and productive system that will ensure that all stakeholders actively participate in the recovery process.

To achieve the above ERS objectives, the Government has taken the following measures:-

- Identified key actions/activities whose implementation will constitute a successful implementation of the ERS;

- Identified a set of indicators that will be used to monitor progress. In this regard, a monitoring and evaluation log frame has been developed;

- The Ministry of Planning and National Development has developed a Monitoring and Evaluation System to be used the monitoring of the ERS. A Monitoring and Evaluation Unit has also been established within the Ministry to coordinate the monitoring of the ERS across all sectors;

- The Sector Working Groups (SWGs) will constitute the operating platform for all stakeholders in the various sub-sectors. The SWGs are responsible for enhancing consultations at sector level in the identification of sector priorities and ensuring that these are given adequate funding through the Medium Term Expenditure Framework (MTEF) budget. The ongoing review of the MTEF system is meant to strengthen the system to ensure that funding goes to priority ERS activities.

- The Government has now institutionalised the Public Expenditure Review PER) system across all ministries and departments to be able to track down the flow of expenditure to priority activities under the ERS. The Ministry of Planning and National Development has established a full time secretariat to coordinate the PER process. The PER Secretariat is already reviewing the budgetary processes including the institutions that are involved in order to identify weaknesses and make recommendations for improvement.

- A Committee of all Permanent Secretaries under the chairmanship of the Head of Public Service and Secretary to Cabinet will get regular briefing on the progress of the implementation of the ERS and give technical guidance. 
- The Cabinet Committee of Economic Management, Chaired by the Vice-President and Minister for Home Affairs will review progress in the implementation of the ERS and give policy guidance.

- The Government has been having regular consultative meetings with development partners through the Economic Governance Group (EGG). The Government will institutionalise the Forum to also discuss the implementation of the ERS.

- The Government is the process of establishing the National Economic and Social Council (NESC). Invitations have already been sent out to various stakeholders to be represented in the Council. Once the Council becomes fully operational, it will be able to assist in giving an independent view on the implementation of programmes and advise on emerging policy concerns. The Ministry of Planning and National Development and Ministry of Finance will host and facilitate discussions in the Forum.

\section{ERS Steering Committee}

Comprising all Permanent Secretaries and with the task of overseeing and guiding the implementation of the ERS. This committee will be guided by reports prepared by the Technical committee under the leadership of the Ministry of Planning and National Development. This committee will meet in every quarter of the fiscal year mainly to ensure that implementation of the ERS priorities is on course and where there could be bottlenecks, they be discussed, resolved and a way forward be defined.

\section{ERS Technical Coordination Committee}

Comprising representatives from Ministry of Finance and Ministry of Planning and National Development should be established. This committee will:

- Liase with implementers within Ministries, Departments and Agencies (MDAs) on a continuous basis and receive and examine reports from Ministries and Departments on the implementation of the actions/activities outlined in the ERS implementation action plan;

- Liase with Sector Convenors who will be spearheading a continuous assessment of the implementation of ERS sector priorities and strategies based on expenditure allocations, identified performance targets and monitorable indicators.

- Compile progress reports/briefing and submit the same to the ERS steering committee. The objective will be to generate information necessary for making strategic policy decisions and adjustments to the implementation strategy.

\section{Government Donor Consultative Forum}

The hitherto dormant Government Donor Consultative Forum has already been established with representatives from all key donor partners, Government ministries and departments. The Minister for Finance chairs this forum. Key representatives from the private sector and civil society could also attend. The role of the Forum is to meet on quarterly basis to review progress on key priority areas identified in the ERS and Investment Programme. This will be similar to the recently held Consultative Group Meeting but mainly involving local representatives of the donors that have already committed resources to the ERS. However, the issues to be discussed 
under this forum will be of broad nature but related to projects that are financed by donors while specific issues will be dealt with at the sector level. For instance a timetable for the various donor missions would be agreed in this forum. Projects financed by donors but implemented by agencies outside government could also be reported under this forum. This forum will ensure mutual accountability by all partners in the process of implementing the development agenda.

\section{National Economic and Social Council}

Once the National Economic and Social Council (NESC) becomes operational, it will be able to assist in giving an independent view on the implementation of programmes and advise on emerging policy concerns. The Ministry of Planning and National Development and Ministry of Finance will host and facilitate discussions in the Forum. 


\section{Chapter 2: Situational Analysis of the Economy and Poverty in Kenya}

After two and half decades of deteriorating economic performance, Kenyan citizens elected a new government in December 2002 that is committed to improving the living standards of all, especially the poor. Despite taking over with severe resource constraints, the government has begun implementing a wide ranging and deep set of reforms. Top on the reform agenda are measures to improve governance and to provide universal primary education.

\section{The Economy}

Since the 1980s, the economy has performed below its potential, with low economic and employment growth and a decline in productivity. Consequently, per capita income in constant 1982 prices declined from US\$271 in 1990 to US\$239 in 2002. The number of people openly unemployed currently stands at over 2 million or 14.6 per cent of the labour force, with the youth accounting for 45 percent of the total. The majority of the unemployed, though educated, do not have necessary skills. In addition, the number of the working poor is staggering comprising primarily subsistence farmers, female-headed households and slum dwellers. Disguised unemployment is also a serious problem, especially in the public sector. Moreover, the incidence of HIV/AIDS has increased, thereby imposing an increasing social and economic burden. The factors underlying the weak economic performance and high incidence of poverty include the persistence of pervasive governance failures, the slow pace of economic reforms, low savings and investment, intermittent shortages and high costs of power, and poor physical and telecommunications infrastructure.

The weak economic growth has been accompanied by deterioration in the fiscal position and a growing domestic debt. As a result of reduction in the tax rates, Government revenue fell from 29 percent of GDP in 1999/2001 to 22 percent in 2002/03. This reduction in tax rates was in line with Government policy of creating an enabling environment for business. However, a weakening tax administration resulting largely from widespread corruption contributed to fiscal pressure as the revenue declined. As the tax revenue declined, public expenditure did not respond concomitantly and continued to come under expansionary pressure on account of increased spending on wages, salaries and interest, as well as the burden of supporting a large parastatal sector. With donor budgetary support falling concurrently, the resulting fiscal pressures was accommodated by a squeeze in spending on operations and maintenance and public investment, an increase in arrears, including pending bills and stalled projects, and growing domestic borrowing.

Despite improvements in governance, several external developments have kept economic growth subdued. Recent data indicate that overall economic performance remained weak due to recent terrorism alert, which has taken a heavy toll on the tourism industry. Partly due to this reason, real GDP growth in 2003 is projected to remain below 2 percent. Excluding food and energy, inflation has risen to 3.7 percent in June 2003 from 1.6 percent in October 2002, reflecting in part a loosening of monetary conditions during 2002 that was accompanied by a depreciation in the nominal and real effective exchange rates of the shilling. While the exchange rate does not appear to have been a major impediment to export performance in recent years, the government has been monitoring exchange rate developments closely, as a continuation of the recent appreciation trend could have adverse effects on export and output growth. 


\section{Poverty Diagnostics in Kenya}

Poverty rose in Kenya during the 1990s. Three national surveys conducted in the 1990's provide valuable information about welfare levels, poverty and other household and individual characteristics. Several poverty profiles have been constructed spanning 1991/92, 1994 and 1997. The surveys are, however out of date and not fully comparable. Nevertheless, it is estimated that the proportion of the population living in poverty has risen from about 48.8 percent in 1990 to 55.4 percent in 2001 . The proportion is estimated to have risen to more than 56 percent in 2003. Poverty increased sharply during the early 1990 s, declined during the mid1990 s, and rose steadily since 1997 . Thus, an additional 2.7 million people were living below the poverty line in 2001 than were in 1997 (from 14.4 million in 1997 to 17.1 million in 2001). Regionally, there are pockets of very high poverty that exceed the national average, calling for deliberate intervention in such regions.

Non-income dimensions of poverty worsened. In step with poor economic performance, key social indicators during the 1990s. Illiteracy rates increased as enrolment rates in primary school declined during the 1990s. Life expectancy declined from 57 years to 47 years between 1986 and 2000, while the situation in infant and child mortality and HIV/AIDS worsened. Preliminary results of the Kenya Demographic and Health Survey conducted in 2003 indicate that Infant mortality increased from 62 per thousand in 1993 to 78 per thousand in 2003, while under five mortality rose slightly from 96 per thousand births to 114 per thousand in the same period. Trends in nutritional status of children under age three show that the percent of stunted children (short for their age) increased from 29 percent in 1993 to 31 per cent in 2003. Similarly, the percent of children aged 12-23 months who were fully vaccinated dropped from 79 percent in 1993 to a dismal 52 percent in 2003. These national averages conceal substantial regional variations. For example, the proportion of children fully vaccinated in Nyanza, Western and North Eastern provinces falls below 50 percent as of 2003.

Estimates on unemployment also indicate an increasing trend over the last two decades. In 1978 the urban unemployment rate was approximately 7 percent. By 1986 it had increased to 16 percent and continued to rise to 25 percent by 1999 . The unemployment rate in the rural areas for the same period was less acute at 9.4 percent, while for Kenya as a whole it was estimated at 14.6 percent. However, underemployment is significant, which has contributed to the existence of a class of Kenyans who are the working poor.

Currently, Geographical variations in the distribution of poverty are large. The WMS indicate that three quarters of the poor live in rural areas while the majority of the urban poor live in slum and peri-urban settlements. The 1994 WMS revealed that North Eastern Province had the highest proportion of people living in absolute poverty (58 percent), the highest in Kenya, followed by Eastern Province (57 percent) and Coast Province (55 percent). In 1997, Nyanza had the greatest proportion of its population living in poverty (63 percent) followed by Coast (62 percent). Moreover, more than 50 percent of the population in all other provinces except for Central (31 percent) were living in poverty. In urban areas, Kisumu town recorded the highest prevalence of poverty (63 percent), followed by Nairobi with 50 percent. Results of poverty mapping in Kenya indicate similar patterns in levels of poverty at the provincial levels, but depict large differentials at the sub-district level. For instance, rural poverty rates within Central province (least poor province in Kenya -31 percent) ranges from 10 per cent to 56 percent across its 171 locations. In Coast, about 61 per cent of the rural people are poor, and poverty ranges from 13 per cent to 90 per cent across the 140 rural locations. As in the rural areas, the urban areas similarly exhibit 
considerable heterogeneity with sub location measures showing high variability in the incidence poverty. In Nairobi, for instance, overall poverty rate is 50 percent, but at the sub-location level (110 sub-locations) poverty ranges between 6 and 78 percent. The poor in urban areas are concentrated in small areas (slums) where living conditions are pathetic. In all provinces except North Eastern, poverty levels show significant variations between locations in the same division and similarly for divisions within the same district. The Poverty mapping estimates also show that people in relatively less poor districts, divisions and locations depict much smaller poverty gaps (consumption shortfalls). Poverty gaps in such areas are typically around 5 percent of the poverty line, whereas in the poorest areas, poverty gaps are in the range of 30 to 50 percent.

Households that are large, headed by females, headed by adults with low educational attainment, or deriving most income from agriculture are more likely to be poor than others. In Kenya, as in other countries, poverty increases with household size. ${ }^{1}$ Thus, households with a larger number of infants and children have a lower level of consumption, and thereby a higher probability of being poor. Female-headed households in urban areas are poorer than otherwise similar households. Not surprisingly, the educations of both the household head and of the spouse appear to be important determinants of poverty. For example, an urban household whose head has at least some primary education has a level of consumption 20 percent higher than a comparable household whose head has no education at all. In rural areas, the gap is only 13 percent. As the level of education attained by the head and spouse increases, the effect on consumption also increase. Working in the non-farm sector in rural areas is associated with a higher level of consumption. Wage workers, whether in the public or private sector, are better off than informal workers such as unpaid family workers. Land ownership, it is associated with higher levels of consumption in rural areas. Land owners can expect a 7 percent increase in consumption versus otherwise similar households, and each hectare of land brings an additional gain.

Determinants of Poverty: The key determinants of poverty in Kenya include location (rural/urban); household size; level of education of head of household, gender (male versus female headed households); agricultural output (cash crop farmers or subsistence farmers); access to land; and ownership of livestock and of selected durable farm tools. Factors highlighted in participatory poverty studies as affecting household consumption include having low agricultural productivity and poor access to markets; being unemployed or earning low wages; living in areas with poor infrastructure (especially roads), and with limited availability of affordable basic services; living with HIV/AIDS or with a disability; being a member of a minority or other group that is discriminated against; and living in an area with a poor and degrading environment. The poor also attribute their poverty to natural calamities, and traditions and cultural beliefs that deny women access to productive assets. The government recognizes that much is still to be done to understand the causes of poverty and to identify interventions that can effectively and rapidly reduce poverty.

Gender Dimensions of Poverty: Social factors and cultural norms emphasize the unequal power status of men and women. Some traditions favour male dominance, resulting in low social status of women. Special efforts are needed to empower women to make them less vulnerable. Efforts are ongoing to mainstream gender in the Economic Recovery Strategy. Constraints, however, include lack of gender-disaggregated analysis, except for the fields of basic education and some areas of healthcare. In addition, gender specific targets for defining

This analysis is based on the 1997 household survey. 
improvements in the economic, social and legal situation are still lacking. The macroeconomic framework that forms the core of the Economic Recovery Strategy is still analyzed in genderneutral terms.

Actions to deepen the understanding of the incidence, depth, trends, distribution, and determinants of poverty: An improved process for poverty diagnostics has been undertaken recently by the government in collaboration with the World Bank, through the establishment of a Poverty Analysis and Research Unit in CBS which is spearheading poverty analysis including poverty mapping exercise aimed at revising the poverty profiles for all the districts. The first volume of the poverty mapping exercise was released in October 2003 and further analysis to produce a volume two on socio economic dimensions is underway. To further improve on prior weaknesses of the WMS type of surveys, the CBS is planning to undertake an Integrated Household Budget Survey in 2004/05, which will provide critical data for estimating poverty headcount, distribution, causes, and trends. These data will provide the basis for a comprehensive poverty assessment to be undertaken during 2005/06. While the comprehensive survey data are very important for assessing poverty trends, the government recognizes a need for frequent information on poverty trends. It therefore plans to implement a program to generate such data through the use of quick monitoring survey instruments such as the Core Welfare Indicators Questionnaire (CWIQ) preferably every 2-3 years.

Such information will be used not only for designing targeted poverty interventions but also for monitoring and evaluating the ERS and MDGs. The information will also be used to develop a scorecard to indicate the number of households/individuals lifted out of poverty every year. 


\section{Chapter 3: Economic Growth}

After two decades of weakening economic growth, low productivity and high unemployment, the ERS's first priority is to restore the economy on a path of high growth as a condition for the achievement of all other developmental objectives. The strategy calls for redefining the role of the state as a facilitator for private sector growth and investment. This will entail strengthening policy and regulatory functions of the state and transferring productive and service delivery activities to the private sector. Within this framework, the government commits to maintaining a stable macroeconomic framework, reforming the financial sector and strengthening its regulations to increase savings and investment, implementing mechanisms for private sector participation in provision of infrastructural services, and establishing a competitive environment able to attract increased private investment in productive sectors such as tourism, industry and trade.

\section{Macroeconomic Framework}

The overall objective of macroeconomic policy is to restore economic growth within a sustainable framework of low inflation, declining fiscal imbalances, declining net domestic borrowing and healthy balance of payments. Specific objectives include increasing domestic savings and investment, improving accountability in the use of public resources, and restructuring and refocusing public spending toward priority activities.

\section{Economic Forecasts}

Table 3.1 below gives the economic forecasts for the period 2003 to 2007 for key economic variables. This forecast is consistent with the expected external environment especially trading partner growth and price levels, prices of key commodity exports and imports and expected growth in external support which will be used to boost Government investment and reduce domestic financing needs. The main elements of the forecast are as follows:

- Economic growth is expected to rise from 1.1percent in 2002 to 1.3 percent in 2003 and continue to reach 4.9 percent in 2007 ;

- Investment growth is expected to be the primary driver for economic growth. Investment levels are expected to rise from 13.6 percent of GDP to 24.3 percent. Domestic savings are expected to rise from 13.8 percent to 18.5 percent over the period, implying that there will be need for substantial external inflows for the investment levels to be achieved.

- Exports and imports are expected to be a major factor in the growth outcome. Exports to begin with are seen to be constrained by the low prices of Kenya's major commodities. However, a quick response by the exporters to the policy regime currently being put in place to make them more competitive is expected to provide almost immediate gains by 2005. As for the imports, the volume growth will be driven mainly by the movements of the other components of the GDP, primarily investments and exports.

- Private consumption is expected to remain low as the Government focuses on investments and as lower proportion of incremental profits is disbursed from the private sector to households.

- Inflation: continuation of the conservative monetary policy will allow Kenya's underlying inflation to remain below 3.5 percent, comparable with the forecasts for trading partner inflation. This will allow for the maintenance of a stable nominal exchange rate policy without risking real appreciation of the Kenyan shilling. Low inflation as well as 
externalization of the deficit is expected to allow the rate of interest on Government debt to remain below 6 percent in the medium term.

Table 3.1: Forecasts for key economic parameters

\begin{tabular}{||l|r|r|r|r|r|r||}
\hline & 2002 & 2003 & 2004 & 2005 & 2006 & 2007 \\
\hline GDP Growth (percent real) & 1.1 & 1.3 & 2.5 & 3.7 & 4.1 & 4.9 \\
\hline Investments (percent of GDP) & 13.6 & 16.5 & 20.4 & 23.3 & 24.4 & 24.8 \\
\hline Investment volume growth (percent) & -1.8 & 23.2 & 26.2 & 18.5 & 9.3 & 6.3 \\
\hline Savings (percent of GDP) & 13.6 & 14.9 & 15.7 & 17.6 & 18.5 & 19.7 \\
\hline Export growth (volume, percent annual) & 5.0 & 15.8 & 2.0 & 4.8 & 9.9 & 12.3 \\
\hline Import volume growth (percent annual) & -16.7 & 13.0 & 18.2 & 10.5 & 9.3 & 8.8 \\
\hline Inflation (percent) & 2.0 & 9.8 & 3.5 & 3.5 & 3.5 & 3.5 \\
\hline
\end{tabular}

\section{Fiscal Strategy for Economic Recovery}

The Government in June 2003 published an Economic Recovery Strategy that will guide major reforms to be undertaken over the period 2003 - 2007. The Budget mechanism presents one of the most fundamental instruments of implementing the economic reforms and other policy options outlined in the ERS in order for the objectives and the outcomes of the strategy to be realised. Core to the Budget is the ability to have a stable and sustainable Macroeconomic Framework. The overall objective of macroeconomic policy in the ERS is to restore economic growth within a sustainable framework of low inflation, declining fiscal imbalances, declining net domestic borrowing and healthy balance of payments. Specific objectives include increasing domestic savings and investment, improving accountability in the use of public resources, and restructuring and refocusing public spending toward priority activities. Fiscal policy together with other instruments such as monetary policy provides the Government with useful handles that can be used to ensure the realisation of the goals of the ERS. In the following section, the fiscal strategy that will guide the Government's fiscal framework in the next three fiscal years is outlined.

\section{Objectives of the Fiscal Strategy}

Kenya's Fiscal Strategy that will cover the period 2003/04-2006/07 has three core objectives. These include Fiscal Sustainability, expenditure restructuring for growth and poverty reduction, and improving public sector service delivery.

Fiscal sustainability: Under this objective, the fiscal policy's aim is to maintain a level of expenditures that can be funded without either an increase in the present value (NPV) of overall debt to GDP or an increase of external debt growth. This is consistent with the desire of the country not to become a Highly Indebted Poor Country (HIPC).

Expenditure restructuring for growth and poverty reduction: This objective will be anchored in increasing the shares of development expenditures especially those targeting Government investments, core social expenditures (education and health) and core poverty expenditures. The increase will be both as a share of total expenditure and as a percent of GDP. 
Improving public sector service delivery: This will entail enhancing both the efficiency and effectiveness of public expenditure through a process of internalizing the Public Expenditure Review (PER) and carrying out Public Expenditure Management (P.E.M.) reform.

The fiscal strategy will serve as the basis for defining a realistic medium term Government finance framework covering revenues, expenditures and financing, which allows for an aggregate expenditure ceiling to be derived that is consistent with the objectives indicated above. The strategy will also allow for the setting of expenditure ceilings both by category and by MTEF sectors.

\section{Factors underlying the Fiscal Strategy}

Several critical factors underlie Kenya's fiscal strategy. The strategy is hinged on the projected performance of the economy. The key factors determining the projected economic performance will be:

a) Recovery and sustained good performance in Kenya's trading partners' growth: Recent economic data shows that the European Union, East African Community, rest of Africa, and East Asia are Kenya's major trading partners accounting for 31 percent, 11.4 percent, 15.7 percent and 14.4 percent respectively of Kenya's major exports. It is forecast that Kenya's trading partners will have an annual average growth rate of 4.2 percent over 2003 to 2007.

b) Forecasts for trading partner inflation: It is also projected that Kenya's trading partners will have a weighted average inflation of between 3.2 to 3.6 percent. Hence, a low inflation regime will be imperative for Kenya's international competitiveness:

c) Growth in export and import prices is expected to be subdued: Kenya's merchandize export basket is heavily oriented towards agricultural products and commodities (coffee and tea account for over 31 percent while manufactured products account for less than 40 percent) while its import basket is heavily biased in favour of petroleum fuels (16.3 percent) chemicals (13.9 percent) machinery and transport equipment (32.4 percent) and manufactured goods (16.3 percent). Given the low price forecasts for both export and import commodities, overall external trade prices are expected to be low.

d) Interest rates: Kenya has recently moved to a low domestic interest rate regime as a result of low underlying inflation and stable exchange rate regime. With restoration of donor support, the Government is expected to rely less on domestic borrowing allowing for interest rates to remain low and stable.

The expected trends of these key economic variables between 2003-2007 are shown in table 3.2 below.

Table 3.2: Forecasts for key economic variables affecting Kenya

\begin{tabular}{|l|r|r|r|r|r|r|}
\hline & $\mathbf{2 0 0 2}$ & $\mathbf{2 0 0 3}$ & $\mathbf{2 0 0 4}$ & $\mathbf{2 0 0 5}$ & $\mathbf{2 0 0 6}$ & $\mathbf{2 0 0 7}$ \\
\hline Trading Partner Growth & 3.70 & 3.37 & 4.17 & 4.44 & 4.45 & 4.45 \\
\hline Trading Partner CPI & 3.24 & 3.52 & 3.58 & 3.25 & 3.25 & 3.25 \\
\hline Growth in Export Prices (Kshs.) & 6.7 & -9.34 & 1.55 & 3.94 & 0.78 & 0.78 \\
\hline Growth in Import Prices & 6.4 & -5.45 & -4.14 & 0.15 & 0.78 & 0.78 \\
\hline Domestic Treasury Bill Rate & 7.9 & 4.0 & 3.00 & 5.00 & 5.00 & 5.00 \\
\hline
\end{tabular}


Like most other low income countries, Kenya relies on its development partners to assist it in accelerating economic development. Table 3.3 shows the trends of inflows during 1999/2000 to $2002 / 03$ fiscal years. Over $1999 / 2000$ to $2002 / 2003$ the Government received disbursements amounting to Kshs 52,436 million of grants (including Kshs 12,444 million of drought related grants in 2000/01 fiscal year) and Kshs 48,480 million of loans (including Kshs 4,382 of drought related loans and Kshs 4,045 of programme loans). Hence, donor inflows into the budget totaled Kshs 100,916 million. However, over the same period the country repaid external principal to the tune of Kshs 90,059, implying that net inflows over the period totaled Kshs 10,857 million, and excluding drought related inflows were negative ${ }^{2}$. The low level of donor support were primarily driven by Kenya being "off track" with key development partners and especially the Bretton Woods institutions.

Table 3.3: External Loans and Grants, 1999/00-2002/03 (Values in Kshs. mn)

\begin{tabular}{|l|r|r|r|r|}
\hline & $\mathbf{1 9 9 9 / 2 0 0 0}$ & $\mathbf{2 0 0 0 / 0 1}$ & $\mathbf{2 0 0 1 / 0 2}$ & $\mathbf{2 0 0 2 / 0 3}$ \\
\hline Programme grants & 4,247 & 5,955 & 1,473 & 458 \\
\hline Project grants (cash) & 938 & 1,521 & 1,090 & 3,804 \\
\hline Project grants (AiA) & 3,309 & 4,160 & 4,260 & 10,777 \\
\hline Drought related grants & 0 & 12,444 & 0 & 0 \\
\hline Project loans (AiA) & 6,020 & 5,323 & 7,133 & 5,276 \\
\hline Programme loans & 0 & 4,045 & 0 & 4,045 \\
\hline Project cash loans & 2,830 & 4,337 & 2,898 & 2,191 \\
\hline Drought related loans & 0 & 4,382 & 0 & 0 \\
\hline Total Grants & $\mathbf{8 , 4 9 4}$ & $\mathbf{2 4 , 0 8 0}$ & $\mathbf{6 , 8 2 3}$ & $\mathbf{1 5 , 0 3 9}$ \\
\hline Total loans & $\mathbf{8 , 8 5 0}$ & $\mathbf{1 8 , 0 8 7}$ & $\mathbf{1 0 , 0 3 1}$ & $\mathbf{1 1 , 5 1 2}$ \\
\hline Total external support & $\mathbf{1 7 , 3 4 4}$ & $\mathbf{4 2 , 1 6 7}$ & $\mathbf{1 6 , 8 5 4}$ & $\mathbf{2 6 , 5 5 1}$ \\
\hline
\end{tabular}

This situation has however changed following Kenya's accessing the IMF's Poverty Reduction and Growth Facility (PRGF) and the holding of a successful Consultative Group (CG) meeting in November 2003 where US\$4.1 billion in support was pledged over 2004-2006. The restoration of working relations with development partners therefore enables the Kenya Government to accept a more ambitious stance with respect to donor assistance to the budget.

\section{Domestic factors}

The following are the key domestic factors that will underlie the economic recovery efforts and thus the fiscal strategy:

- Response of private investors to the incentives and measures put in place by the Government,

- The capacity of the Government to absorb the external inflows and the restructuring capacity given the need to shift resources from one expenditure category to another,

- The Monetary policy stance adopted by the Central Bank of Kenya,

\section{Private Investment}

Private investments in Kenya have continued to perform below expectation and to a large extent the poor performance explains partly the slow economic growth that the economy has transited

\footnotetext{
${ }^{2}$ The level of net external resources accessed by Kenya on a per capita basis was as low as US\$1 over the period.
} 
to. An in-depth analysis of private investment behaviour in Kenya indicates that private investment is driven by: growth in national income; profitability; interest costs; crowding-in factor of public investments; and availability of credit to the private sector. The link with the interest costs is weak implying that fiscal policy lends itself as a more effective instrument that the Government can use as part of its economic recovery strategy to stimulate investments.

The measures currently in-built in the ERS in line with the key determinants of private investments in the country is the restructuring of public expenditures towards public investments outlined in this strategy. Immediate dividends through the crowding-in factor of such public investments are expected will create a positive response for the private investments. In addition, the public investments will are expected will reduce the costs, particularly infrastructural facing private firms, and this will lead to increased profitability. Private investors in the country on average have been shown to re-invest one-third of their profits net of interest costs in a given year. The increased profits through lower costs occasioned by public investments are also likely to be positively augmented by a continuation during the ERS implementation period of strong fiscal policy that addresses the profitability of private businesses through the use of current tax policy that allows faster depreciation of machinery and equipment. This has a direct effect of raising retained earnings in businesses and subsequently private investments.

The principal objective of fiscal policy under the ERS is fiscal consolidation to reduce domestic debt, and fiscal restructuring to reallocate resources to high priority programs. The budget envisages substantial reduction in domestic borrowing requirements which will maintain the ongoing efforts to remove competition between the public and private sector for domestic credit. With the realisation of increased credit availability for the private sector, it is anticipated that the impetus for private investments will be supported.

\section{Government Capacity}

The public sector has been undergoing continual reform since the early 1990's with a view to reducing the share of Government recurrent expenditure (especially wages) and increasing the development budget. The country has however failed to register any major successes in this areas as indicated by the continually rising wage bill, under provision for operations and maintenance and declining development vote. Given the ambitious targets of the recovery strategy, achieving success in restructuring the public sector and enhancing its capacity will be paramount. Success in this area will depend on the following:

- Internalising the MTEF process to ensure all budgets are MTEF budgets;

- The Public Expenditure Review (PER) process which seeks to institutionalise an annual Ministerial PER (MPER) process and use this annual process as the basis for guiding resource allocation; and

- The Public Expenditure Management (PEM) reform process which seeks to improve the efficiency and effectiveness of Kenya's public expenditure and ensure the tax payer gets value for money.

\section{Fiscal Strategy targets}

The fiscal strategy is built around the following key areas: 
- A revenue policy framework that seeks to maintain revenues to GDP at above 21 percent to enable the bulk of government expenditures to be met from domestic resources excluding borrowing,

- An expenditure strategy that gradually reduces the level of recurrent expenditure to GDP to allow for a rapid increase in development expenditures within a sustainable macro economic framework. Public Expenditure management reforms and the MPERS will be used to redirect expenditures to national priorities and away from low priority areas,

- Reducing the budget deficit from 4 percent of GDP in 2003/04 to below 3 percent of GDP by 2005/06 and focusing deficit financing on concessional external borrowing to allow for a reduction in the level of domestic debt to GDP and for maintenance or lowering of the present value (NPV) of overall debt to GDP.

\section{Revenues}

Table 3.4 below shows the recent revenue performance as well as projections for 2003/042006/07 consistent with the fiscal strategy. Kenya's recent revenue experience has seen the revenue to GDP ratio decline from 23.3 percent in 1999/2000 to 20.8 percent in 2002/03. In 2003/04 the ratio is expected to remain below 21 percent of GDP. Decline in revenue performance has been occasioned by a reduction in tax rates partly as a result of liberalization measures and partly as a means of lowering consumption costs, to non adjustment of specific tax rates for inflation and to administrative and capacity constraints. Government policy will focus on arresting the decline in the revenue to GDP ratio to ensure the ratio is maintained above 21 percent. The overall tax and administrative reform agenda will focus on achieving the above revenue target as well as ensuring that revenue enhancement measures are not based on additional taxation.

Table 3.4: Revenue and Grants, 1999/00-2006/07

\begin{tabular}{|l|r|r|r|r|r|r|r|r|}
\hline & $\mathbf{1 9 9 9 / 2 0 0 0}$ & $\mathbf{2 0 0 0 / 0 1}$ & $\mathbf{2 0 0 1 / 0 2}$ & $\mathbf{2 0 0 2 / 0 3}$ & $\mathbf{2 0 0 3 / 0 4}$ & $\mathbf{2 0 0 4 / 0 5}$ & $\mathbf{2 0 0 5 / 0 6}$ & $\mathbf{2 0 0 6 / 0 7}$ \\
\hline Total revenue & 178,443 & 192,312 & 194,507 & 210,759 & 228,819 & 255,907 & 285,109 & 310,689 \\
\hline Direct taxes* & 54,402 & 54,497 & 60,555 & 70,452 & 73,113 & 70,865 & 79,485 & 83,737 \\
\hline Indirect taxes & 98,042 & 10,7342 & 104,294 & 112,455 & 119,124 & 137,555 & 152,196 & 163,573 \\
\hline Non-tax revenue** & 25,999 & 30,473 & 29,658 & 27,852 & 36,582 & 38,386 & 41,174 & 47,460 \\
\hline Revenue enhancement measures*** & 0 & 0 & 0 & 0 & 0 & 9,100 & 12,254 & 15,919 \\
\hline Revenue/GDP & 23.34 & 22.91 & 21.00 & 20.78 & 20.83 & 21.66 & 22.34 & 22.42 \\
\hline Grants**** & 8,494 & 24,080 & 6,823 & 15,039 & 24,108 & 27,028 & 22,518 & 23,357 \\
\hline Total revenue and grants & 186,937 & 216,392 & 201,330 & 225,798 & 252,927 & 282,934 & 307,627 & 334,046 \\
\hline Revenue and grants/GDP & 24.4 & 25.8 & 21.7 & 22.3 & 23.0 & 23.9 & 24.1 & 24.1 \\
\hline
\end{tabular}

\section{Tax reform}

The objectives of tax reform are to improve transparency and efficiency of taxation, strengthen tax collection to maintain a revenue/GDP ratio at or above 21 percent, and harmonize tax systems within the East African Community (EAC). To improve the structure of taxation, the government will undertake an assessment of tax policy and its impact on the economy and make the tax system more pro-growth and sensitive to the poor. This will be achieved by undertaking a comprehensive review of past policy regime, evaluate its effects on growth and poverty and use the lessons learnt to draw a pro-growth tax policy regime. In particular, the Government will 
establish an optimal tax rate framework for those tax heads considered high currently, institute tax regime that encourages new investments, economic growth and employment creation and use tax instruments to make social interventions for alleviating poverty.

In view of the prevailing low tax efforts for a number of tax heads, the Government will make expansion of the tax base a priority. This is in recognition of the relationship between tax policy and tax administration capacity. Towards this end, the Government is well aware that without effective tax administration infrastructure, little economic growth can be achieved through tax policy instruments. Making tax administrative effective will achieved by instituting effective enforcement in revenue administration. To strengthen tax collection, the reform will implement a modernization of tax administration, including computerization of the tax administration infrastructure through the development of integrated information architecture. In addition, as already initiated, Kenya Revenue Authority will implement a functional based tax administration to enhance efficiency and effectiveness of the tax administration system in Kenya. Further system support enhancements to Income Tax, Value Added Tax and Customs functions and strategic capacity building and development will be will a priority.

Harmonization and rationalization of tax regimes and integration of trade arrangement within the EAC and COMESA includes, among others, the lowering of tariffs and other barriers to imports of goods from the rest of the world. The loss in revenue arising from trade arrangements and subsequent tariff reductions will be compensated for by enhanced customs administration capacity, especially through implementation of regional transit cargo control strategy, deployment of scanners at the ports of entry to assist with valuation and verification, computerization of customs operations and effective management of warehouse.

During the 2003/04 - 2005/06, Kenya Revenue Authority's operational reform agenda will be guided by the 2003-2006 Corporate plan. Among the key goals envisaged are the reorganization of the tax administration, restructuring the port handling facilities and procedures of revenue administration, implementing effective strategy for the management of excisable products, enforcing the withholding requirement by public sector and collection-agents to enhance compliance with tax laws and revamped and streamline the bond and transit cargo management. Other reform measures include strict enforcement of the traffic Act and development of new number plates and second generation driving licenses to improve compliance.

\section{Expenditure}

Despite the declining performance on the revenue side, the bulk of Kenya's fiscal strategy will need to focus on expenditure reduction, expenditure restructuring and expenditure reform. Whereas Kenya's revenue performance at over 21 percent of GDP has been above par for low income countries, Kenya's expenditure levels at over 26percent of GDP have been significantly above that for low income countries, yet the public investments level at below 2.5percent of GDP is below the recent sub Saharan African performance. The country also has a poor public expenditure management record with only 3 out of 16 indicators of public expenditure management being considered acceptable $\mathrm{e}^{3}$.

\footnotetext{
${ }^{3}$ The focus of the Public Expenditure Management Reform is in the 3 core areas of expenditure performance, namely, budget formulation, budget execution and budget reporting. 15 initial indicators were identified for measuring performance. A review carried out in 2003 found that Kenya found that only 3 of the 15 indicators were rated as acceptable. A $16^{\text {th }}$ indicator has since been added.
} 
Table 3.5 below shows the major categories of expenditure over 1999/2000-2002/03 and the forecast of the fiscal strategy over 2003/04-2006/07.

Table 3.5: Expenditure, 1999/00-2006/07

\begin{tabular}{|c|c|c|c|c|c|c|c|c|}
\hline & $1999 / 2000$ & 2000/01 & $2001 / 02$ & $2002 / 03$ & $2003 / 04$ & 2004/05 & 2005/06 & 2006/07 \\
\hline Consolidated fund services & 116,333 & 89,634 & 107,661 & 107,478 & 131,540 & 118,676 & 118,699 & 121,341 \\
\hline Of which: Principal repayment & 79,921 & 52,530 & 59,998 & 54,453 & 80,034 & 74,661 & 71,686 & 71,142 \\
\hline Payment of arrears & & & 4,104 & 3,295 & 0 & 0 & 0 & 0 \\
\hline Foreign interest due & 8,635 & 7,803 & 6,357 & 8,459 & 6,419 & 5,991 & 5,752 & 6,194 \\
\hline Foreign interest paid & 8,635 & 3,479 & 7,858 & 8,459 & 6,419 & 5,991 & 5,752 & 6194 \\
\hline Domestic interest (inc. CBK Comm.) & 20,752 & 23,232 & 23,744 & 26,767 & 27,323 & 21,090 & 21,724 & 21,816 \\
\hline Wages and salaries & 132 & 146 & 153 & 353 & 360 & 367 & 374 & 382 \\
\hline Constitutional Review & & 300 & 1,100 & 701 & 800 & 0 & 0 & 0 \\
\hline Goods and services & 296 & 281 & 215 & 215 & 215 & 215 & 215 & 215 \\
\hline Current transfers(pensions) & 4,717 & 5,709 & 8,627 & 11,653 & 13,493 & 15,517 & 17,844 & 20,521 \\
\hline Capital transfers (guaranteed loans) ${ }^{*}$ & 1,880 & 3,957 & 1,862 & 1,582 & 2,897 & 835 & 1,103 & 1,072 \\
\hline Discretionary Expenditures & 140,464 & 198,008 & 175,669 & 212,984 & 245,813 & 280,837 & 289,244 & 318,456 \\
\hline Total Expenditures & 256,797 & 287,642 & 283,330 & 320,461 & 377,354 & 399,513 & 407,943 & 439,797 \\
\hline Total Expend. Excluding principal & 176,876 & 235,112 & 223,332 & 266,008 & 297,320 & 324,852 & 336,257 & 368,655 \\
\hline Total Exp. Exc. Principal/GDP percent & 23.1 & 28.0 & 24.1 & 26.2 & 27.1 & 27.5 & 26.4 & 26.6 \\
\hline
\end{tabular}

As shown in the table above, total expenditure excluding interest grew from Kshs. 176,876 million in 1999/2000 to Kshs. 266,008 million in 2002/03, an annual average growth of 14.6percent.. There was a consistent trend of rising expenditure to GDP, from 23.1percent in $1999 / 2000$ to 26.2 in $2002 / 03^{4}$. The fastest growing component of expenditures was the pensions expenditures which grew at an annual average of 41percent over this period. Given that the rise in expenditure coincided with declining revenue performance, it will clearly be imperative to rein in expenditure growth as a key plank of the fiscal strategy.

In achieving the expenditure objective of restructuring to focus on poverty alleviation, promotion of economic growth and increasing access of the poor to social services, the following will be the main areas to be covered by the expenditure strategy:

- Reducing overall expenditure to GDP ratio as the primary means by which the budget deficit will be brought down to sustainable levels;

- Raising the level of development expenditure from 4.3 percent of GDP in 2002/03 to [6.7 percent] by $2006 / 07$,

- Ensuring that core poverty expenditures are maintained at or above 4percent of GDP;

- Ensuring that the wage bill to GDP ratio declines to 8.5 percent by $2005 / 06$ and to 7.2percent by $2007 / 08$;

- Reducing the overall level of transfers to subvented bodies (universities and parastatals);

- Increasing expenditures on health in a manner consistent with achieving 12percent of total expenditures by 2010 while maintaining the level of primary education expenditures;

- Improved public expenditure management by tackling PEM shortcomings and internalizing the annual MPER process,

\footnotetext{
${ }^{4}$ The rapid increase in expenditure in 2000/01 was due to drought related expenditures.
} 
- Reduction in Government contingent liabilities through termination or completion of stalled projects and elimination of pending bills.

Table 3.6 below shows the forecast expenditure outcomes by economic categories. The major forecasts are:

- Overall expenditure is expected to rise from Kshs 266,008 million to Kshs 370,623 million over 2002/03-2006/07 representing a rise from 26.2 percent of GDP to 26.5 percent of GDP; and

- Expenditure composition is expected to change in favour of development (from 16.3 percent in 2002/03 to 25percent in 2006/07) and core poverty (from 7.3percent to 8.3 percent over the same period) while wages (from 32 percent to 31 percent) and interest payments (from 13.2 percent to 7.6 percent) and transfers to paratstatals and universities (from 5.4 percent to 5.0 percent) decline.

Table 3.6: Economic Analysis of Expenditure, 1999/00-2006/07

\begin{tabular}{|c|c|c|c|c|c|c|c|c|}
\hline & $1999 / 2000$ & $2000 / 01 *$ & $2001 / 02$ & $2002 / 03$ & $2003 / 04$ & $42004 / 05$ & $2005 / 06$ & $2006 / 07$ \\
\hline Total Expend. excl. principal & 176876 & 235112 & 223332 & 266008 & 297320 & 324852 & 336257 & 368655 \\
\hline Wages and salaries & 65861 & 68119 & 78125 & 85087 & 96716 & 101583 & 108514 & 115585 \\
\hline Retrenchment costs & 443 & 6095 & 1665 & 957 & 0 & 5335 & 0 & 0 \\
\hline Goods and services & 56256 & 84215 & 74454 & 83071 & 92267 & 96697 & 97941 & 103843 \\
\hline Of which: core poverty programmes & 6696.14 & 9232 & 10150 & 14536 & 18347 & 20100 & 21708 & 23577 \\
\hline Transfers and subsidies & 8224 & 11280 & 14008 & 17636 & 27246 & 30103 & 25637 & 28503 \\
\hline Interest & 29387 & 31035 & 30101 & 35226 & 33742 & 27081 & 27476 & 28010 \\
\hline Other (Constitutional review) & & 300 & 1100 & 701 & 800 & & & \\
\hline Development & 16705 & 34068 & 23879 & 43330 & 46549 & 64054 & 76688 & 92715 \\
\hline Of which: core poverty programmes & 9704.58 & 8751 & 12599 & 19487 & 24790 & 27158 & 29332 & 31856 \\
\hline Wages / Exp. (percent) & 37.24 & 28.97 & 34.98 & 31.99 & 32.53 & 31.27 & 32.27 & 31.35 \\
\hline Retrenchment/Exp (percent) & 0.25 & 2.59 & 0.75 & 0.36 & 0.00 & 1.64 & 0.00 & 0.00 \\
\hline G\&S / Exp. (percent) & 31.81 & 35.82 & 33.34 & 31.23 & 31.03 & 29.77 & 29.13 & 28.17 \\
\hline Transfers / Exp. (percent) & 4.65 & 4.80 & 6.27 & 6.63 & 9.16 & 9.27 & 7.62 & 7.73 \\
\hline Interest / Exp. (percent) & 16.61 & 13.20 & 13.48 & 13.24 & 11.35 & 8.34 & 8.17 & 7.60 \\
\hline Dev. / Exp. (percent) & 9.44 & 14.49 & 10.69 & 16.29 & 15.66 & 19.72 & 22.81 & 25.15 \\
\hline Core poverty programmes/Exp/(percent) & 5.49 & 3.72 & 5.64 & 7.33 & 8.34 & 8.36 & 8.72 & 8.64 \\
\hline $\begin{array}{l}\text { Transfers to parastatals \& } \\
\text { universities/Exp.(percent) } \\
\end{array}$ & & 5.99 & 7.54 & 5.42 & 5.49 & 5.14 & 5.24 & 5.03 \\
\hline Wages/Revenue (percent) & 36.91 & 34.93 & 35.95 & 40.37 & 37.93 & 38.55 & 36.34 & 35.63 \\
\hline $\begin{array}{l}\text { Transfers to parastatals \& universities/GDP } \\
\text { (percent) }\end{array}$ & & 1.68 & 1.82 & 1.42 & 1.48 & 1.41 & 1.38 & 1.34 \\
\hline Core poverty programmes (percent of GDP) & 2.14 & 2.14 & 2.46 & 3.35 & 3.93 & 4.00 & 4.00 & 4.00 \\
\hline Development expenditures/GDP (percent) & 2.18 & 4.06 & 2.58 & 4.27 & 4.24 & 5.42 & 6.01 & 6.69 \\
\hline
\end{tabular}

The above forecasts are based on the following underlying assumptions and measures:

- Wages and salaries: Wages are expected to decline from 8.7 percent of GDP in 2003/04 to 8.5 percent by $2005 / 06$. The Government, in 2003/04, awarded substantial increases to the disciplined forces (police and prisons) as well as begun implementation of the teachers salary award. No awards have as yet been given to civil servants. Achieving the 8.5 percent target by 2005/06 will require that any awards to be provided to the civil servants or any additional awards (other than the remaining phases of the teachers' awards) will be matched by a proportionate downsizing of the civil service. To this end, 21,500 civil servants are 
forecast to leave the service through a Voluntary Early Retirement (VER) scheme to enable civil service wages to be raised as part of an overall pay and benefits strategy.

- Interest payments: the fiscal strategy is based on the premise that the Government will be able to raise substantial additional external resources and thus allow for a reduction in both domestic borrowing levels and interest rates. The Central Bank will also continue with its policy of lengthening the term structure of domestic debt,

- Ministerial recurrent expenditures: non-wage ministerial expenditures (excluding transfers to subvented bodies) depend on exchequer releases and Appropriations in Aid (AiA) expenditures. The strategy assumes that these expenditures will be maintained constant in real terms, other than education, health and core poverty expenditures.

- Transfers to parastatals and universities: are expected to be maintained at their 2003/04 levels in real terms, with any increases in personnel emoluments being catered for through downsizing,

- Pensions: Kenya currently operates a non-contributory pension scheme. Pension payments have however been rising at an unsustainable rate and there will be a need to reduce these expenditures. The Government is scheduled to introduce a contributory pension scheme in the 2004/05 fiscal year. The fiscal strategy assumes that pension payments will continue to rise at 15 percent per year, but an early introduction of the contributory scheme could lower this growth.

- Core poverty expenditures: The main objective of re-prioritizing and selecting the core poverty programmes was to allocate and ring-fence resources to those programmes that have a direct impact in reducing poverty levels in the medium term. The objective of the core poverty expenditures is to ring fence and deliver a set of programmes that improve access of the poor to infrastructural and social services especially rural infrastructural services, education and health, enhance the capacity of the poor to participate in productive service activities, and improve the governance and security environment.

The Government has recently reexamined its list of ring fenced core poverty expenditures and updated the list. In 2002/03 core poverty expenditures were expected to account for Kshs.34,043 million or 3.35 percent of GDP. In 2003/04 the Government expects to spend Kshs. 43,137 million or 3.93percent of GDP over 2004/05-2006/07 the policy objective is to maintain core poverty expenditures at 4percent of GDP. Consequently, Kshs. 153,729 million is expected to be spent on core poverty expenditures over this period.

- Guaranteed loans and capital transfers: the major components of this category have tended to be Government repayments of parastatal debt. However, the Government has adopted an ambitious strategy to restructure the National Bank of Kenya (NBK). It is proposed that over 2003/04 and 2005/06 Kshs. 12,000 million be used in this endeavour.

- Health expenditures: the Government is committed to raising the level of health expenditures to at least 12percent of total expenditures as part of its strategy for providing adequate health services. Since overall recurrent health expenditures were 6.7 percent of total recurrent expenditures, achieving the 12percent target by 2010 will require that recurrent health expenditures grow by at least 7.5 percent faster than overall expenditures. The fiscal strategy assumes that these health expenditures will be focused on non wage non transfer expenditures and will thus enable the rapid increase in basic health services.

- Development expenditures: Over the recent past development expenditures in Kenya have declined as a percentage of total expenditures and as a percentage of GDP. Implementing the ERS will require a massive increase in development expenditures. Over 2002/032006/07 development expenditures are expected to rise from Kshs. 43,330 million to Kshs. 
92,715 million, an annual average of 23.6percent. Over 2003/04-2006/07 a total of KShs. 280,006 million will be available for implementing development projects in the ERS.

- Stalled projects: Over the 1990s Kenya built up a substantial inventory of stalled projects as lax fiscal control led to the initiation of more projects than could be sustained by the development budget. As a result, by 1997 the completion rate for projects was as low as 3 percent. Stalled projects, those projects that were initiated, not completed and which are currently not receiving funding, mushroomed. By 1999, the Government had a total of 164 stalled projects with an estimated original contract cost of Kshs. 31,357 million, accrued expenditures of Kshs. 13,319 million and an estimated completion cost of Kshs. 13,227 million for those than could be completed and Kshs. 2,448 million for those that required termination. By 2003 the stalled projects were estimated to have increased to 207. The Government will review all stalled projects with a view to terminating as many as possible and only completing those that fall in the ERS core priority areas or which have potential for meeting ERS core objectives. It is estimated that reviewing the stalled projects will cost Kshs. 90 million.

\section{Public Expenditure reform}

The 1997 Public Expenditure Review concluded that expenditure management trends were not consistent with the objectives of achieving sustained growth and poverty reduction. Following this review, the Government introduced a number of reforms to strengthen expenditure management. These include: The adoption of Medium Term Expenditure Framework (MTEF) approach to budget formulation in 2000/01; establishment of the Budget Monitoring Department in 2000; introduction of the Integrated Financial Management Information System (IFMIS); and ministerial rationalization. The 2003 PER noted that expenditure management weaknesses identified in the 1997 PER still persist.

The Government recognizes that economic recovery efforts will require efficient use of public resources and sound management of public expenditure geared towards enhanced service delivery and value for taxpayer's money. In this regard, the government has institutionalized PER as part of the wider efforts to improve budget planning, execution and monitoring. In June 2003, a comprehensive public expenditure management reform program was initiated. This program includes legislative changes to improve the legal framework for public expenditure management as well as institutional and system changes. It incorporates the recommendations emanating from the Country Financial Accountability Assessment (CFAA) and a Public Expenditure Management Assessment and Action Plan (PEMAAP) exercises, both carried out by the Government in collaboration with key development partners.

As part of the PER institutionalization process, the Government issued the Treasury Circular No $26 / 2003$ dated $3^{\text {rd }}$ December to initiate the 2004 PER process at the ministry level. Unlike the 2003 PER which involved only eight key ministries, the process has been rolled out to cover all the other ministries and integrated with the MTEF budget process. The PER will support the budget process by analysing expenditure allocations and budget institutions to identify weaknesses and recommend measures to enhance the impact of public expenditure. The MTEF budget process is being reviewed and the exercise will also involve development of an action plan to strengthen the budget process. 
The IFMIS has been procured and IFMIS team and supervisors trained. Piloting of the system in the Ministries of Finance and Planning and National Development started in January 2004 and roll out to all other ministries is expected by mid 2004.

The government is improving the legislative framework for Public Expenditure Management (PEM). This includes: the enactment of the Anti-Corruption and Economic Crimes Bill (facilitated the establishment of an anti-corruption commission) and the Public Officer Ethics Bill (requiring the declaration of wealth by public officers) in 2003. Additional three pieces of legislation have been published and are awaiting enactment. These are: The Government Financial Management Bill (2003), which aims at enhancing accountability in public financial management practices; the Public Audit Bill (2003)- which aims at strengthening the independence and operational capacity of the Controller and Auditor General; and the Public Procurement and Disposal of Assets Bill (2003) which aims at enhancing the oversight role of the Directorate of Public Procurement.

The government is creating the institutional framework in which these reforms can be effectively designed and implemented; establishing a robust program of analysis and evaluation that can be the basis for building the expenditure management reform program; and defining a timetable for reforms. Priorities include: i) the creation of strong coordination and management arrangements between the departments in the Ministry of Finance and the Ministry of Planning and National Development that have lead responsibility for designing and implementing the expenditure management reform program; ii) phased reform of the MTEF; iii) implementation of short term reforms set out in the government's Action Plan for Enhanced Financial Management in the Public Sector; vi) adherence to the timetable for the budget process for $2004 / 05$; vii) early conclusion of the PER work program to provide information on the costing of ERS priority programs, and savings from low priority programs, and track expenditures of core poverty programs; and viii) design of MTEF budget for 2004/05 based on early decisions on the macroeconomic framework and sector ceilings, on the objectives of the ERS, and on the analysis of the PER.

Development partners are supporting the public expenditure management reform through a technical coordination group that includes each of the main donors' active in this area. In addition to supporting the PER process, the development partners are members of the PER steering committee and technical working group. These arrangements already provide a means for coordinated dialogue. Further, the government is exploring the use of a formal common memorandum of understanding to capture donor assistance to the PER. Development partners will consider the provision of basket funding within this framework for the PER and other aspects of the public expenditure management reform program.

\section{Public Expenditure Management Reform}

Public expenditure management has been a major weakness in Kenya in recent years. In particular, Kenya has had declining performance with respect to forecasting expenditures and/or disbursing the same. As table 3.7 below shows, the poor performance has been especially visible with respect to the development budget. Over 2000/01-2002/03 less than 40percent of projected ministerial development expenditure were actually realized. Given the rapid increase in development expenditures required to ensure the recovery targets are met, the Government will be focusing its efforts on improving public expenditure management. 
Table 3.7: Projcted and Actual Ministerial Expenditure (values in Kshs. mn)

\begin{tabular}{|c|r|r|r|r|r|r|r|r|r|}
\hline \multirow{2}{*}{ Year } & \multicolumn{3}{|c|}{ Actual } & \multicolumn{3}{c|}{ Target } & \multicolumn{3}{c|}{ Actual/Target (percent) } \\
\cline { 2 - 10 } & Recur. & Develop. & \multicolumn{1}{c|}{ Total } & Recur. & Develop. & Total & Recur. & Develop. & Total \\
\hline $1999 / 2000$ & 108809 & 7095 & 115904 & 109169 & 7339 & 116508 & 99.67 & 96.68 & 99.48 \\
\hline $2000 / 2001$ & 144019 & 22998 & 167017 & 149216 & 20012 & 169228 & 96.52 & 114.92 & 98.69 \\
\hline $2001 / 2002$ & 154403 & 14668 & 169071 & 163975 & 43577 & 207552 & 94.16 & 33.66 & 81.46 \\
\hline $2002 / 2003$ & 165724 & 19111 & 184835 & 182247 & 49735 & 231982 & 90.93 & 38.43 & 79.68 \\
\hline $99 / 00-02 / 03$ & 572955 & 63872 & 636827 & 604607 & 120663 & 725270 & 94.76 & 52.93 & 87.81 \\
\hline
\end{tabular}

Following recommendations from a Country Financial Accountability Assessment (CFAA) study done in 2001 and the Public Expenditure Management Assessment and Action Plan (PEMAAP) exercise done in 2003, an Enhanced Financial Management Action Plan was prepared. Since the recommendations covered a broad scope, it was decided that concentration be focused first on the public sector before moving to the private sector actions.

The main objectives of the Enhanced Financial Management Action Plan include:-

- Enabling the Government to focus resources within realistic fiscal constraints, on core priorities including economic recovery and poverty eradication. These will be achieved through improving and strengthening the tools used in the budget preparation and in particular, the MTEF process;

- Dealing comprehensively with the issue of pending bills and preventing future recurrence by improving the quality of budget preparation, broadening commitment control, and strengthening financial discipline through timely reconciliation and reporting;

- Improving the quality and timeliness of information available for financial management decision making, through the establishment of improved and relevant reporting systems. Facilitation in the medium term will be by the implementation of the government-wide integrated financial management information system.

To achieve the above objectives, the Enhanced Financial Management Action Plan addresses the following key areas:

- Budget Formulation - focus is on government policies, resource allocation, comprehensiveness, classification and projections

- Budget Execution - this covers issues on financial management procedures which include commitment control, payment management, project management, procurement and debt management

- Monitoring and Evaluation - the effort is to improve internal audit systems; monitoring of expenditures especially on those projects/programmes aimed at reducing poverty; achieving timely and accurate information; and, better information sharing.

- Institutional and Human Resources - actions will include undertaking a review of available and required financial management skills and other associated resources; and, articulating roles and responsibilities of central and line ministries in the management of financial resources.

- State Corporations - the main actions will include, reviewing of the overall government policy on investments, rationalization and restructuring of the parastatals, review of the parastatal financing policy, and review of procedures for accounting and monitoring of the remaining state corporations. 


\section{Public Expenditure Tracking (PETS)}

The Kenya Government recognizes the importance of Public Expenditure Tracking (PETS) as a tool for diagnosing problems of service delivery and as a cost effective way for overcoming systemic problems in service delivery. To this end, it has already initiated a pilot PETS, which was carried out by the Kenya Institute for Public Policy Reasearch and Analysis (KIPPRA).

KIPPRA conducted a Public Expenditure Tracking Survey (PETS) in 2003. The PETS covered education, health, and the agriculture sectors. The KIPPRA survey had the following shortcomings:

- It does not track expenditures through the release system in terms of identifying the amounts allocated to particular votes, and tracking them down to the end user.

- It does not clearly define the kind of leakages that exist.

Recognizing the weaknesses of the KIPPRA study, the Government has initiated the process of undertaking another PETS. Programmes aimed at directly having a positive impact in poverty reduction have been identified and the second PETS will focus on tracking expenditures for specific core poverty programmes. Two programmes, (i) School Equipment Scheme and (ii) Bursary Programme for primary schools have been identified as pilot programmes for the exercise. Preliminary preparations started in early March 2004.

\section{Deficit and Financing Strategy}

The objectives to be pursued by the deficit and financing strategy are to first reduce the overall deficit including grants to a sustainable level and secondly to externalize deficit financing to reduce pressure on domestic financial markets and increase private sector access to credit. Over the medium term the deficit is expected to decline to below 3 percent of GDP, while net domestic borrowing is forecast for rapid reduction and ultimate elimination.

The provisional overall deficit for 2002/03 was Kshs. 40,210 million or 3.96 percent of GDP. Current forecasts for revenue and expenditure for 2003/04 indicate a widening of this deficit to Kshs. 49,700 or 4.52 percent of GDP, mainly driven by increased expenditures on the free education programme and health. Initial actions on restructuring the NBK as well as wage awards to the teachers and disciplined forces. As this fiscal strategy is implemented, this deficit is expected to decline to 3,67 percent in 2004/05, 2.38 percent in 2005/06 and 2.64 percent in $2007 / 08$.

There will therefore be need for deficit financing over the fiscal strategy period. The Public Sector Borrowing Requirement (PSBR) is expected to total Kshs. 460,640 million over 2003/04 and Kshs. 330,906 million over 2004/05-06/07. Of the Kshs. 460,640 million, Kshs. 159,917 million will be required for financing the cumulative deficits, Kshs. 76,559 million will be required for external redemption, Kshs. 220,964 for domestic redemptions and Kshs. 3,000 million projected for paying of pending bills.

Financing the deficit will focus on maximizing external concessional borrowing consistent with maintaining the external debt to GDP ratio of below 36 percent. Given the nominal GDP forecasts and projected exchange rate movements, external borrowing over 2003/04-2006/07 is expected to total Kshs. 198,306 million, of which Kshs. 26,647 million will be rescheduling, and over 2004/05-2006/07 Kshs. 143,385 million of which Kshs. 20,718 million will be 
rescheduling. Net external borrowing over 2003/04-2006/07 will then total Kshs. 121,747 million, compared to a net repayment of Kshs 25,225 million over 1999/2000-02/03.

With external debt accounting for Kshs. 198,306 million, there will be need for domestic financing totalling Kshs. 262,334 million over 2003/04 and Kshs. 187,521 million over 2004/0506/07. Of the 262,334 million, Kshs. 220,964 million will be accessed by rolling over domestic debt, while the remainder, Kshs. 41,370 million will be accessed through additional domestic borrowing. Of the Kshs. 187,521 million over 2004/05-06/07, Kshs. 165,723 will be accessed by rolling over domestic debt while Kshs. 21,798 will be accessed from additional domestic borrowing.

The outcome of the deficit and financing strategy is expected to be an external debt to GDP ratio that remains below the 36 percent level achieved in 2002/03 and a domestic debt to GDP level that declines from 24.3 percent in 2002/03 to 20.8 percent in 2006/07. Such declines will lead to a significant reduction in the Present Value (NPV) of debt to GDP ratio.

Privatization proceeds: The Government has published a privatisation bill which will lay the legal framework for its privatisation programme. Once the bill is enacted into law, the privatization process is expected to begin in earnest. This fiscal strategy has not factored in privatisation proceeds. However, should they arise, they will be used to reduce the net domestic borrowing requirement. 
Table 3.8: Deficit and Financing Strategy, 2003/04-2006/07

\begin{tabular}{|c|c|c|c|c|c|c|c|c|}
\hline & $1999 / 2000$ & $2000 / 01$ & $2001 / 02$ & $2002 / 03$ & 2003/04 & $04 / 05$ & $2005 / 06$ & $2006 / 07$ \\
\hline Deficit before grants (commitment basis) & 1567 & -42800 & -28825 & -55249 & -68501 & -68945 & -51148 & -57966 \\
\hline Deficit before grants/GDP(percent) & 0.20 & -5.10 & -3.11 & -5.45 & -6.24 & -5.84 & -4.01 & -4.18 \\
\hline Overall Deficit (Revenue+Grants-Exp.) & 10061 & -18720 & -22002 & -40210 & -44393 & -41918 & -28630 & -34609 \\
\hline Overall Deficit/GDP percent & 1.32 & -2.23 & -2.38 & -3.96 & -4.04 & -3.55 & -2.24 & -2.50 \\
\hline Overall Deficit: cash basis & 4026 & -15608 & -30286 & -38005 & -44393 & -42918 & -29630 & -35609 \\
\hline Repayment of domestic principal & -48903 & -45374 & -38458 & -36897 & -55241 & -55241 & -55241 & -55241 \\
\hline Repayment of external principal (current FY) & -31018 & -7156 & -21540 & -17556 & -24793 & -19420 & -16445 & -15901 \\
\hline Repayment of external principal (arrears) & 0 & -5390 & -4104 & -3295 & 0 & 0 & 0 & 0 \\
\hline Public sector borrowing requirement & -75895 & -73528 & -94388 & -95753 & -124427 & -117579 & -101316 & -106751 \\
\hline External financing (borrowing) & 15546 & 18087 & 10031 & 11512 & 48992 & 38207 & 37063 & 47397 \\
\hline External financing (rescheduling) & 0 & 21793 & 0 & 0 & 5929 & 8930 & 8064 & 3724 \\
\hline External Financing (change in arrears) & 0 & 5886 & 2738 & 1114 & 0 & 0 & 0 & 0 \\
\hline Privatisation proceeds & 5660 & 0 & 955 & 0 & 0 & 0 & 0 & 0 \\
\hline Sale of housing & & & & 0 & 0 & 0 & 0 & 0 \\
\hline Domestic financing needs & 54689 & 27762 & 80664 & 83128 & 69505 & 70442 & 56189 & 55630 \\
\hline Change in pending bills & -2285 & 5163 & -765 & 6686 & 0 & 0 & 0 & 0 \\
\hline Securitised pending bills & 3472 & 3538 & 2788 & 4481 & 0 & 1000 & 1000 & 1000 \\
\hline IMF PRGF & 0 & 1968 & 0 & 0 & 0 & 0 & 0 & 0 \\
\hline Net foreign borrowing & -15472 & 5541 & -12875 & -8226 & 30128 & 27717 & 28682 & 35220 \\
\hline As percent of GDP & -2.02 & 0.66 & -1.39 & -0.81 & 2.74 & 2.35 & 2.25 & 2.54 \\
\hline Net domestic borrowing & 17536 & 616 & 47334 & 44025 & 14264 & 15201 & 948 & 389 \\
\hline As percent of GDP & 2.29 & 0.07 & 5.11 & 4.34 & 1.30 & 1.29 & 0.07 & 0.03 \\
\hline Total domestic debt & 206127 & 213773 & 227655 & 296378 & 310643 & 325844 & 326792 & 327180 \\
\hline On lending & & 5701 & 5701 & & & & & \\
\hline Govt. deposits and Treasury advances & 42722 & 38357 & 24880 & 49578 & 49578 & 49578 & 49578 & 49578 \\
\hline Net domestic debt & 163405 & 164205 & 202775 & 246800 & 261065 & 276266 & 277214 & 277602 \\
\hline Net domestic debt/GDP percent & 21.37 & 19.56 & 21.90 & 24.33 & 23.77 & 23.38 & 21.73 & 20.03 \\
\hline Total external debt & 409419 & 390971 & 376859 & 364582 & 387351 & 416602 & 449941 & 488672 \\
\hline total External Debt to GDP (percent) & 54 & 47 & 41 & 36 & 35 & 35 & 35 & 35 \\
\hline Expenditure - Interest & 147489 & 204077 & 193231 & 230782 & 263578 & 297771 & 308781 & 340645 \\
\hline Primary surplus & 39448 & 12315 & 8099 & -4984 & -10651 & -14837 & -1154 & -6599 \\
\hline Primary surplus/GDP percent & 5.16 & 1.47 & 0.87 & -0.49 & -0.97 & -1.26 & -0.09 & -0.48 \\
\hline Expenditure - Capital & 158291 & 197087 & 197591 & 221096 & 247874 & 259963 & 258466 & 274868 \\
\hline Current surplus & 20152 & -4775 & -3084 & -10337 & -19055 & -4056 & 26643 & 35821 \\
\hline Current surplus/GDP percent & 2.64 & -0.57 & -0.33 & -1.02 & -1.73 & -0.34 & 2.09 & 2.58 \\
\hline GDP at market prices & 764624 & 839534 & 926039 & 1014441 & 1098497 & 1181449 & 1275992 & 1385831 \\
\hline
\end{tabular}

\section{External Aid and Debt Policy Framework}

Kenya's external debt and Foreign Aid policy framework is built around the following Principles:

- Maintaining Kenya's external debt sustainability to ensure Kenya does not become a Highly Indebted Poor Country (HIPC) or Severely Indebted Low income Country (SILIC); 
- Ensuring only concessional borrowing is contracted to minimize servicing costs and maximize the grant element of borrowing;

- Implementing a Foreign Aid policy that harmonizes donor practices along the lines proposed in the Rome Declaration of February 2003 and minimizing the transaction costs related to external aid; and

- Ensuring that foreign aid is aligned to the national budget, the national development priorities and implementation should be based on best practice principles.

\section{External debt}

During January 2004, the Paris Club of Creditors agreed to reschedule US\$ 350 million of arrears and maturities for interest and principle falling due between January 2004 and $31^{\text {st }}$ December 2006. The rescheduling was done on Houston terms It is anticipated that on completion of this rescheduling, the county will graduate from future Paris Club rescheduling.

Kenya's external debt policy is guided by the accepted principle that the country shall obtain and service her debt on a timely basis as per the signed loan agreements. It is also premised on the recognition that there is an optimal debt level above which the economy may not be able to sustain. Any variations to this premise have to be authorized by Parliament for which an adequate explanation based on macro-economic parameters has to be considered.

To ensure that the country is able to finance its deficits in a sustainable manner, the country's debt strategy will be built around the following

- Focusing on external concessional debt as a means of reducing the NPV of debt, lengthening the term structure of debt and reducing servicing costs,

- Mitigating exchange rate risk through currency diversification and improving forecasting of repayments to ensure repayments do not undermine the foreign exchange reserves position,

- Refinancing to replace expensive debt with less expensive debt, and

- Where necessary, rescheduling on Houston terms to mitigate cash flow problems.

\section{Foreign Aid policy}

The government has initiated measures for the development and eventual publishing of an External Aid Policy to guide in the optimal utilisation of external resources received from development partners. The policy will aim to harmonize and simplify donor practices in the country, as required under the Rome Declaration of February 2003 to which Kenya is a signatory. The policy will provide a framework for effective multilateral and bilateral negotiations and assess capacity building needs to manage external resources. The objective is to increase external inflows, and improve disbursement rates. It is envisaged that an External Aid Policy will be in place before December 2004. 


\section{External Resource Requirements}

In considering the overall external resource requirements for the ERS, the following were taken into account:

i. Total demand for foreign exchange for all purposes, including for imports, debt service and buildup of official reserves, taking into account the macro projections and requirements;

ii. Projections of resource availability taking into account macro level projections of exports, private and public transfers, foreign direct investment, other projected private inflows and the public inflows for which there are existing commitments;

iii. Estimation of the financing gap taking into account existing; and

iv. Taking account of resources pledged during the Consultative Group (CG) meeting held in November 2003 and implications for disbursement levels if the ERS is to be adequately funded.

\section{Overall Financing Needs}

The overall external financing framework including the financing gap is shown in table 3.10 below. Total financing needs are estimated at US\$ 23,513 million over 2003-06 and US\$25,398 million over 2004-2007. These requirements include the following:

a) Overall import demand of US\$ 20,191 million over 2003-2006 and US\$ 22,097 million for 2004-07 of which US\$ 4,909 million will be required for 2004 alone;

b) Total debt service of US\$1,377 million over 2003-2006 and US\$1,249 million over 2004-07 of which US\$ 380 million will be required in 2004;

c) IMF repayments estimated at US\$ 56 million over 2003-06 and US\$ 49 million over 2004-07 of which US\$14 million are required in 2004;

d) US\$ 1,418 million needed for buildup of official reserves over 2003-06 and US\$ 1,567 million over 2004-2007; and

e) Estimated private interest payments of US\$ 365 million and US\$ 387 million over the two periods respectively.

\section{Domestically available Resources}

Domestically available resources are estimated to total US\$20,083 million over 2003-06 and US\$ 21,728 million over 2004-07 and include the following:

f) Merchandise exports estimated to total US\$11,221 million over 2003-2006, and US\$ 12,348 million over 2004-07 of which 2004 merchandise exports are expected to total US\$ 2,788 million;

g) Service exports estimated to total US\$ 4,878 million over 2003-2007 and US\$ 5,042 over 2004-07 with a 2004 estimate of US\$ 1,077 million;

h) Net foreign direct investment (FDI) of US\$ 234 million over 2003-2006 and 257 million over 2004-07 with a 2004 estimate of US\$ 55.4 million;

i) Private transfers of US\$ 1,466 million over 2003-06 and US\$ 1,378 million over 2004-07 with US\$ 376 million estimated for 2004,

j) Other capital movements (private) estimated at US\$ 1,975 million over 2003-2006 and US\$2,301 million over 2004-07 with 2004 estimated to total US\$ 535 million $^{5}$.

\footnotetext{
${ }^{5}$ Other capital movements are also assumed to include under estimates for tourism receipts
} 
Given the required external resources, this leaves a financing gap of US\$ 3,430 million over 2003-2006 and 3,670 million over 2004-2007.

\section{Existing External Commitments to the Public Sector}

In closing the financing shortfall the Government, based on existing commitments, expects to have access to US\$ 2,439 million over 2003-04 and US\$ 2,645 over 2004-07. These commitments comprise the following ${ }^{6}$ :

a. Project grant support of US\$ 984 million over 2003-2006 and US\$ 1,156 million over 2004-2007;

b. Project loans of US\$ 778 million over 2003-2006 and US\$ 1,016 million over 20042007;

c. Other public loans of US\$251 million over 2003-06 and US\$ 209 million over 2004-07;

d. Projected IMF disbursements of US\$261 million over 2003-06 and US\$ 265 million over 2004-07;

e. Paris Club rescheduling of pre-cutoff $\operatorname{debt}^{7}$ : following agreement with the Paris Club the country can expect to benefit from US\$ 341 million of rescheduling over 2003-06 and US\$ 295 million over 2004-07; and

f. Programme support already received in 2003 and 2004 totaling US\$ 165 million.

These resource estimates leave a residual financing gap of US\$ 649 million over 2003-06 and US\$ 730 million over 2004-07. This implies total external support of US\$3,430 million over 2003-06 and US\$ 3,670 million over 2004-07. This compares to US\$ 4,100 million pledged during the 2003 Consultative Group meeting. The implication is that virtually all the pledges made during the consultative meeting will need to be turned into commitments if the external financing gap is to be closed. Virtually all the additional resources will need to be programme support to the budget to reduce the domestic borrowing requirements to sustainable levels.

Table 3.9: External Financing Requirements

\begin{tabular}{|c|c|c|c|c|c|c|c|c|}
\hline (Values in \$mn) & 2002 & 2003 & 2004 & 2005 & 2006 & 2007 & $\begin{array}{l}2003- \\
6\end{array}$ & 2004-07 \\
\hline \multicolumn{9}{|l|}{ Domestic Resources Available } \\
\hline Merchandise exports & 2165 & 2424 & 2788 & 2880 & 3129 & 3551 & 11221 & 12348 \\
\hline Service exports & 1112 & 1258 & 1077 & 1211 & 1332 & 1422 & 4878 & 5042 \\
\hline Private transfers & 576.8 & 421.11 & 376 & 335 & 334 & 333 & 1466 & 1378 \\
\hline Foreign Direct investment (net) & 50 & 50.4 & 55.4 & 61 & 67.1 & 73.8 & 234 & 257 \\
\hline Earnings from reserves & 35.4 & 46.6 & 56.5 & 89.7 & 116.2 & 139.6 & 309 & 402 \\
\hline Other capital (net) & -5 & 306 & 535 & 502 & 632 & 632 & 1975 & 2301 \\
\hline TOTAL & 3934 & 4506 & 4888 & 5079 & 5610 & 6151 & 20083 & 21728 \\
\hline \multicolumn{9}{|l|}{ Financing Needs } \\
\hline Imports & 3740 & 4277 & 4909 & 5279 & 5726 & 6183 & 20191 & 22097 \\
\hline Net factor payments & 32 & 6 & 13 & 12 & 12 & 12 & 43 & 50 \\
\hline Debt service: principal & 253 & 277 & 291 & 235 & 210 & 210 & 1013 & 945 \\
\hline Debt service : interest & 86 & 106 & 89 & 84 & 84 & 47 & 364 & 304 \\
\hline IMF repayments & 19 & 19 & 14 & 9 & 14 & 12 & 56 & 49 \\
\hline Reduction in arrears & 107 & 64 & 0 & 0 & 0 & 0 & 64 & 0 \\
\hline
\end{tabular}

\footnotetext{
${ }^{6}$ The commitments refer to agreements already signed with the IMF as part of the PRGF process as well as firm commitments in the forms of project loans and grants. Prograsmme support referred to here is that which has already been disbursed.

${ }^{7}$ Pre December 1991 debt
} 


\begin{tabular}{|l|r|r|r|r|r|r|r|r|}
\hline Private interest payments & 76 & 80 & 90 & 95 & 100 & 102 & 365 & 387 \\
\hline Buildup of official reserves & 3 & 192 & 168 & 462 & 596 & 341 & 1418 & 1567 \\
\hline OOTAL & $\mathbf{4 3 1 5}$ & $\mathbf{5 0 2 1}$ & $\mathbf{5 5 7 4}$ & $\mathbf{6 1 7 5}$ & $\mathbf{6 7 4 2}$ & $\mathbf{6 9 0 7}$ & $\mathbf{2 3 5 1 3}$ & $\mathbf{2 5 3 9 8}$ \\
\hline FINANCING GAP & $\mathbf{3 8 1}$ & $\mathbf{5 1 5}$ & $\mathbf{6 8 7}$ & $\mathbf{1 0 9 7}$ & $\mathbf{1 1 3 1}$ & $\mathbf{7 5 5}$ & $\mathbf{3 4 3 0}$ & $\mathbf{3 6 7 0}$ \\
\hline External Public Financing (estimated) & & & & & & & 0 & 0 \\
\hline Project grants (cash) & 32 & 44 & 141 & 101 & 103 & 103 & 389 & $\mathbf{4} 47$ \\
\hline Project grantrs (AiA) & 97 & 81 & 132 & 188 & 194 & 194 & 595 & $\mathbf{7 0 9}$ \\
\hline Programme grants & 12 & 106 & & & & & 106 & 0 \\
\hline Project loans (AiA) & 48 & 29 & 98 & 154 & 193 & 193 & 474 & 639 \\
\hline Project loans (Cash) & 33 & 26 & 87 & 93 & 98 & 98 & 304 & 377 \\
\hline Drought related loans & 0 & 0 & 0 & 0 & 0 & 0 & 0 & 0 \\
\hline Programme loans & 26 & 58 & & & & & 58 & 0 \\
\hline Defense loans & 30 & 33 & 32 & 21 & 21 & 21 & 107 & 95 \\
\hline IMF diusbursements & 0 & 36 & 75 & 75 & 75 & 40 & 261 & 265 \\
\hline Parastatal borrowing & 39 & 56 & 36 & 26 & 26 & 26 & 144 & 114 \\
\hline TOTAL & $\mathbf{3 1 7}$ & $\mathbf{4 6 9}$ & $\mathbf{6 0 1}$ & $\mathbf{6 5 9}$ & $\mathbf{7 1 0}$ & $\mathbf{6 7 5}$ & $\mathbf{2 4 3 9}$ & $\mathbf{2 6 4 5}$ \\
\hline Others & & & & & & & 0 & 0 \\
\hline Rescheduling of principal & 0 & 26 & 79 & 79 & 57 & 0 & 240 & 214 \\
\hline Rescheduling of interest & 0 & 13 & 32 & 30 & 19 & 0 & 94 & 81 \\
\hline Change in arrears & 64 & 7 & 0 & 0 & 0 & 0 & 7 & 0 \\
\hline Sub-Total & $\mathbf{6 4}$ & $\mathbf{4 6}$ & $\mathbf{1 1 0}$ & $\mathbf{1 0 8}$ & $\mathbf{7 6}$ & $\mathbf{0}$ & $\mathbf{3 4 1}$ & $\mathbf{2 9 5}$ \\
\hline FINANCING GAP & $\mathbf{0}$ & $\mathbf{0}$ & $\mathbf{- 2 5}$ & $\mathbf{3 3 0}$ & $\mathbf{3 4 5}$ & $\mathbf{8 0}$ & $\mathbf{6 4 9}$ & $\mathbf{7 3 0}$ \\
\hline
\end{tabular}

\section{Higher case scenario}

The high case scenario is predicated on a faster response of the economy to the bold economic reforms envisaged in the ERS resulting on a growth increase from 1.4 percent in 2002/2003 to 2.4 percent in 2003/2004 and 5.5 percent growth in 2006/07 to deliver an average yearly growth of 3.9 percent during 2003-2007.

In this scenario recovery is driven by a better performing export sector and investment. Exports would grow at 6 percent in 2003/04 from 5.8 percent growth in 2002/2003, and peak at 7.6 percent growth in 2006/2007. Gross investment would increase from 11.4 percent of GDP in $2002 / 2003$ to 16.7 percent in 2006/07. Higher consumer confidence would support the pace of economic recovery with a private consumption growth rising from -6.7 percent in 2002/03 to 1.0 percent in 2003/04 and 3.3 percent in 2006/07. The faster growth in household consumption is in line with the desired policy of its growth being at least higher than the population growth rate. Gross domestic savings would improve gradually from 9.0 percent of GDP in 2002/03 to 9.6 percent in 2003/2004 and 14.6 percent in 2006/2007.

Imports would be expected to rise in response to the recovery in investments and private consumption. Export growth is expected to continue as the potential existing under COMESA and EAC continue to be exploited with the improved competitiveness of the Kenyan exports. AGOA related exports are also expected to continue expanding and these will sustain the expected higher export growth. The current account is therefore expected to be around 2 percent of GDP and the import cover to improve from 3.3 months of imports in 2002/03 to 7.7 months in 2005/06. 
The objective of fiscal policy is to maintain revenues at above 21 percent of GDP and achieving a sustainable overall deficit (including grants) of below 3.2 percent of GDP over the 2003/2004$2006 / 07$ period. The restructuring of public expenditure would entail public consumption to rise slightly from 14.8 to 15.5 percent of GDP during 2002/03-2003/04 due to increased social spending commitments, and thereafter fall to 14.3 percent of GDP in 2005/06. Salaries and wages of the civil service, teachers' service and the disciplined forces which are part of public consumption would remain at below 8.5 percent of GDP over the period 2003/04-2006/07. Transfers to parastatals and universities will be maintained at current levels i.e. below 1.8 percent of GDP which is equivalent to 6.9 percent of total expenditures over the period 2003/042006/07. Total capital expenditure would rise from 4.1 percent of GDP in 2002/03 to 4.7 percent of GDP in 2003/04 and 5.9 percent of GDP in 2005/06 and eventually rise to 6.3 percent in 2006/07. This reflects an increasing proportion of capital expenditure in the budget from 16.2 percent of total expenditures in 2002/03 to 23.4 percent in 2006/07.

\section{Low case scenario}

Te basic purpose of the low case scenario is to investigate what would be the impact on the base case scenario were the economy to be affected by various shocks which would undermine some of the key assumptions underpinning the base case scenario. To construct the low case scenario, the following assumptions were made:

- The country's return to good relations with the donors does not lead to high inflows and anyway, absorptive capacity constraints undermine the potential to absorb all available funding. Hence actual disbursements remain in line with 1999/2000-2002/03 levels,

- The rescheduling agreed with the Paris Club of creditors is not reversed,

- The Central Bank of Kenya continues with its monetary policy targeting 3.5 percent underlying inflation rate,

- Terms of trade do not deteriorate further due to the low prices for commodities already existing and the lack for a basis to assume higher oil prices,

- Private sector response to the changed policy and institutional environment is muted, meaning that investment does not recover as fast as expected.

Table 3.10 below provides the outcomes for the major economic variables under this scenario.

Table 3.10: Economic Outturn for Low Case Scenario (Annual percentage changes, unless otherwise specified)

\begin{tabular}{|c|c|c|c|c|c|c|}
\hline & 2002 & 2003 & 2004 & 2005 & 2006 & 2007 \\
\hline GDP (factor cost and constant prices) & 1.1 & 1.3 & 0.9 & 1.2 & 1.5 & 1.7 \\
\hline Consumer Price Index & 2.0 & 9.8 & 3.7 & 3.2 & 3.6 & 3.6 \\
\hline Exports Volume growth & 5.0 & 6.6 & 9.7 & 4.5 & 4.4 & 5.3 \\
\hline Imports Volume growth & -18.7 & 3.6 & 3.9 & 3.3 & 2.5 & 3.3 \\
\hline Gross National Savings (percent of GDP) & 13.40 & 13.17 & 13.81 & 14.32 & 14.51 & 15.12 \\
\hline Govt. External Debt (US\$ mn) & 4690 & 4696 & 4563 & 4575 & 4545 & 4522 \\
\hline $\begin{array}{l}\text { Govt. External Debt Service Ratio } \\
\text { (percent) }\end{array}$ & 10.49 & 10.00 & 9.09 & 7.10 & 6.17 & 5.68 \\
\hline Govt. Foreign Interest Payments Ratio & 2.88 & 2.60 & 1.99 & 1.75 & 1.66 & 1.60 \\
\hline Interest Rates & 7.9 & 4.0 & 8.00 & 8.0 & 8.00 & 8.00 \\
\hline
\end{tabular}

As a result of the expected shocks, the economy experiences lower growth, lower levels of external debt, slower growth in import volumes and higher domestic interest rates due to the need for increased domestic borrowing to meet budgetary requirements. 
This poor performance would be in line with the low growth phase that the economy transited between 1997 and 2002.

To appreciate the major areas of change, table 3.11 below indicates the magnitudes of change of major variables from the base case scenario.

Table 3.11: Magnitudes of Changes in Key Economic Aggregates

\begin{tabular}{|c|c|c|c|c|c|c|c|}
\hline & 2003 & 2004 & 2005 & 2006 & 2007 & 03-06 & '04-07 \\
\hline GDP growth (Real, percentage points decline) & 0 & -2 & -2 & -3 & -3 & -2 & -2 \\
\hline Exports (US\$ milion reduction) & 82 & 140 & 189 & 83 & -65 & 494 & 348 \\
\hline Imports (US\$ million) & 76 & -453 & -623 & -842 & $-1,022$ & $-1,842$ & $-2,940$ \\
\hline Savings/GDP percent points change & -2 & -2 & -3 & -4 & -5 & -3 & -3 \\
\hline Investment/GDP ratio: percent points change & -2 & -7 & -10 & -11 & -11 & -7 & -9 \\
\hline Estimated change in formal employment(000"s) & 0 & -18 & -31 & -36 & -49 & -85 & -134 \\
\hline $\begin{array}{l}\text { Estimated change in poverty rates(percent } \\
\text { points) }\end{array}$ & & 1 & 2 & 2 & 4 & & \\
\hline Inflation rate (percent points decline) & 0 & 0 & 0 & 0 & 0 & 0 & 0 \\
\hline $\begin{array}{l}\text { Treasury bill interest rates (percent points } \\
\text { change) }\end{array}$ & -4 & 5 & 3 & 3 & 3 & 2 & 4 \\
\hline Revenues (Kshs billion, Fiscal Year) & 0 & $-10,420$ & $-24,517$ & $-34,376$ & 0 & $-69,312$ & $-69,312$ \\
\hline External Grants (Kshs. Billion, Fiscal year) & $-11,320$ & $-17,603$ & $-11,736$ & $-13,792$ & 0 & $-54,451$ & $-43,131$ \\
\hline Net external borrowing (Kshs million, Fiscal yr) & $-35,573$ & $-29,356$ & $-28,605$ & $-38,610$ & 0 & $-132,144$ & $-96,571$ \\
\hline $\begin{array}{l}\text { Net resources shortfall (incl. External } \\
\text { borrowing) }\end{array}$ & $-46,892$ & $-57,379$ & $-64,858$ & $-86,778$ & 0 & $-255,907$ & $-209,015$ \\
\hline
\end{tabular}

From the table above the following are the major impacts;

i. GDP growth declines by an average of 2percent points over 2003-2007. Given that economic growth is the major driver for poverty reduction, poverty rates are estimated to increase by 3 percentage points compared to the base case;

ii. With the assumption of employment growth being tied to economic activity a net total of 80,000 jobs are lost over 2003-2006 and 134,000 over 2004-2007,

iii. The tight monetary framework leads to inflation remaining as per the base case. However, the need for domestic borrowing increases the domestic (t-bill and bond) interest rates by 3 percentage points over the period,

iv. Investment rates are substantially lower as a result of Government not being able to access investible resources and the lower than expected response by the private sector. Since the base case assumed a much higher dependence on foreign savings for investment, there is a lower savings gap and thus improved balance of payments,

v. Imports decline drastically improving the trade balance. The main drivers are reduced importation of investment goods and those commodities (oil products, chemicals and manufacturing inputs) that tend to grow in line with GDP,

vi. The greatest impact is however felt on the budget. Over the 2004/05-2006/07 fiscal period, revenues decline by a cumulative total of Kshs. 69,312 million, while net external borrowing declines by Kshs. 132,144 million and external grants by Kshs. 54,461 million, for a cumulative resource shortfall (compared to the base case) of Kshs. 255,907 million. It is this resource shortfall that the Government expenditures will have to adjust to.

Government adjustment to a resource constrained scenario will be based on 2 core principles: 
- To the largest extent possible fiscal sustainability must be maintained. This will be interpreted to mean that whereas it may be impossible to maintain a declining domestic debt position, the overall debt to GDP ratio should be maintained in present value terms. Thus, given that the NPV of external debt is below its face value, the net increase in domestic borrowing shall only compensate for the shortfall in NPV of external borrowing, ${ }^{8}$

- $\quad$ To the largest extent possible expenditures in education and health and core poverty expenditures will be shielded from expenditure cuts.

Table 3.12 below shows the expected adjustments that would occur under this scenario.

Table 3.12: Adjustments to Reduced Revenues and External Resource Inflows in Low Case Scenario

\begin{tabular}{|l|r|r|r|r|r|}
\hline & & & & & \multicolumn{1}{l}{$03 / 04-$} \\
(values in Kshs million) & $2003 / 04$ & $2004 / 05$ & $2005 / 06$ & $2006 / 07$ \\
\hline & & & & & \\
\hline Change in net domestic borrowing & 46446 & 24652 & 30670 & 40111 & $\mathbf{1 4 1 8 7 9}$ \\
\hline Change in total expenditures & -446 & $-32,726$ & $-34,188$ & $-46,668$ & $\mathbf{- 1 1 4 0 2 8}$ \\
\hline Of which interest payments & 0 & 14,870 & 12,477 & 15,692 & $\mathbf{4 3 0 3 9}$ \\
\hline Of which wages and salaries & 0 & 1967 & 2007 & 2047 & $\mathbf{6 0 2 1}$ \\
\hline Of which ministerial expenditures & 0 & -842 & $-1,427$ & $-1,879$ & $-\mathbf{4 1 4 8}$ \\
\hline Of which transfers to subvented bodies & 0 & 0 & -110 & -147 & $-\mathbf{2 5 6}$ \\
\hline Of which free education and health** & 0 & -27 & -51 & -79 & -157 \\
\hline Of which development expenditures & -12446 & -34220 & -45258 & -60554 & $\mathbf{- 1 5 2 4 7 8}$ \\
\hline Other changes in total expenditures & 12,000 & $-14,475$ & $-1,825$ & $-1,748$ & $-\mathbf{6 0 4 8}$ \\
\hline & & & & & \\
\hline Change in core poverty expenditures & 0 & -648 & $-1,695$ & $-3,060$ & $\mathbf{- 5 4 0 3}$ \\
\hline
\end{tabular}

${ }^{*}$ Excluding education and health

The following are the major adjustments resulting from the adjustment scenario adopted:

- Domestic borrowing is increased by Kshs. 141,879 million over 2003/04 to 2006/07 to counter the net external outflows and maintain the NPV/GDP ratio of overall debt. The domestic debt/GDP ratio rises from 24.6.percent in 2002/03 to 32.9percent in 2006/07 compared to a decline to 21 percent in the base case,

- Interest payments increase as a result of both increased domestic borrowing and increased interest rates,

- Expenditures on wages and salaries are assumed to increase given that the programme grants required for downsizing are no longer forthcoming while the legally binding teacher's salary awards will still need to be honoured. The scenario assumes no salary awards for civil servants,

- Ministerial expenditures (excluding education, health, defence and subventions) decline as they are maintained in real terms only,

\footnotetext{
${ }^{8}$ The Debt Sustainability analysis done in 2002 found that the NPV of external debt was approximately 70 percent of its face value. Thus, in the context of maintaining a constant NPV/GDP ratio, only 70percent of the external borrowing shortfall will be converted to domestic borrowing.
} 
- Transfers to subvented bodies (parastatals, universities and the KRA) are assumed maintained constant in real terms with the decline being attributed to a lower estimate for the GDP deflator,

- Changes in core poverty expenditure result from a lower GDP growth with the Government maintaining a policy of keeping core poverty expenditures at 4percent of GDP,

- The minimal decline in health and education expenditures is attributable to a reduction in health expenditures. With the rapid decline in resources, it proves impossible to maintain a sustainable fiscal situation as well as rapidly increase health expenditures. However, given the substantial increase in the non wage non transfer health expenditures, (from Kshs. 3,481 million to 9311 million), there is a substantial real increase in health expenditures. Free education expenditures remain at previous levels,

- The major casualty is development expenditures which were scheduled to rise fastest under the base case scenario. In this scenario, development expenditures decline by a cumulative total of Kshs. 152,478 million to maintain overall fiscal balance. It is this decline in development expenditures and the knock on effect on private investment that is the major cause of the reduced growth rate.

In an ideal situation, a downward reduction in external inflows and revenues should not be allowed to affect either the level of the core poverty expenditures or the development expenditures. However, given the previous commitments and the difficulty of expenditure adjustments in the absence of external support. This low case scenario represents a realistic adjustment to the potential shocks.

\section{Monetary Policy Framework}

The Kenya Government will continue to focus monetary policy on maintaining stability in the general price level and fostering the functioning of a stable market based financial system. In line with this objective and cognizant of projected inflation in the country's major trading partners, the Central Bank of Kenya (CBK) will continue with its policy of keeping overall inflation below 5 percent annually while targeting underlying inflation of 3.5 percent.

In the short to medium term, the Government will rely on monetary targeting as the principal monetary policy tool. In the framework, broad money supply (M3X) will be the intermediate target and reserve money will serve as the operating target. Broad money, M3X, comprises currency outside banking institutions, term and non-term deposits held by the private and the public sectors but excluding central and local government in banking institutions and residents' foreign currency deposits with local banks. Reserve money comprises currency in circulation and deposits of commercial banks and non-bank financial institutions at the Central Bank.

To facilitate effective implementation of the monetary policy, the Central Bank will continue to rely on Open Market Operations (OMO), cash ratio requirements, and rediscount facilities to influence monetary aggregates.

During the Economic Recovery Strategy period, money supply is projected to increase at 8.1 percent per year by December 2007 as shown in table 3.13 below. This will adequately support the projected real economic growth. Both net foreign assets and domestic credit to the economy will support the money supply growth projected. Net foreign assets of the Banking system are projected to rise by 13.6 percent while domestic credit is expected to rise by 4.9 percent by December 2007. Over the ERS period, it is programmed, that credit will be redistributed to both 
Government and private sector. Government will gradually reduce its borrowing from the domestic sources paving way for increased lending to the private sector. Private sector credit is programmed to accelerate by 14.9 percent while credit to Government will decline by 37.6 percent in the year to December 2007.

Table 3.13: Monetary Survey, percentage annual growth rates

\begin{tabular}{|l|r|r|r|r|r|r|r|r|r|r|r|}
\hline & $\begin{array}{r}\text { Dec. } \\
\mathbf{2 0 0 2}\end{array}$ & $\begin{array}{r}\text { Jun. } \\
\mathbf{2 0 0 3}\end{array}$ & $\begin{array}{r}\text { Dec. } \\
\mathbf{2 0 0 3}\end{array}$ & $\begin{array}{r}\text { Jun. } \\
\mathbf{2 0 0 4}\end{array}$ & $\begin{array}{c}\text { Dec. } \\
\mathbf{2 0 0 4}\end{array}$ & $\begin{array}{c}\text { Jun. } \\
\mathbf{2 0 0 5}\end{array}$ & $\begin{array}{c}\text { Dec. } \\
\mathbf{2 0 0 5}\end{array}$ & $\begin{array}{c}\text { Jun. } \\
\mathbf{2 0 0 6}\end{array}$ & $\begin{array}{c}\text { Dec. } \\
\mathbf{2 0 0 6}\end{array}$ & $\begin{array}{c}\text { Jun. } \\
\mathbf{2 0 0 7}\end{array}$ & $\begin{array}{c}\text { Dec. } \\
\mathbf{2 0 0 7}\end{array}$ \\
\hline 1.Net foreign assets & 8.2 & 6.6 & 8.4 & 13.6 & 16.9 & 19.9 & 25.5 & 30.2 & 22.5 & 16.5 & 13.6 \\
\hline 2.Net Domestic assets & 10.9 & 12.4 & 6.5 & 5.0 & 4.3 & 3.6 & 1.1 & -1.3 & 1.1 & 3.6 & 5.0 \\
\hline 3.Domestic credit & 9.3 & 12.0 & 7.4 & 4.5 & 4.1 & 3.7 & 1.6 & -0.4 & 1.7 & 3.7 & 4.9 \\
\hline 4.Government (net) & 21.9 & 30.7 & 16.2 & 3.9 & -1.8 & -7.3 & -14.4 & -22.0 & -25.8 & -30.5 & -37.6 \\
\hline 5.Rest of the economy & 4.7 & 4.9 & 3.6 & 4.8 & 6.9 & 8.9 & 8.6 & 8.3 & 11.1 & 13.7 & 14.7 \\
\hline 6. Other public sector & -0.1 & -4.7 & -19.8 & 3.5 & 3.5 & 3.5 & 3.5 & 3.5 & 3.5 & 3.5 & 3.5 \\
\hline 7. Private & 4.8 & 5.2 & 4.4 & 4.9 & 7.0 & 9.0 & 8.7 & 8.5 & 11.3 & 13.9 & 14.9 \\
\hline 8.Other items (net) & 1.7 & 10.6 & 11.7 & 2.3 & 3.1 & 4.0 & 4.1 & 4.2 & 4.3 & 4.5 & 4.7 \\
\hline 9. M3X & 10.2 & 10.9 & 7.0 & 7.1 & 7.5 & 7.9 & 7.9 & 7.9 & 8.0 & 8.1 & 8.1 \\
\hline
\end{tabular}

\section{Exchange rate policy}

Since the mid 1990's Kenya has been committed to a flexible, market determined exchange rate policy. Exchange controls were abolished following the repeal of the Exchange Control Act in 1994. This flexible exchange policy has been fundamental to ensuring that the country's balance of payments remains sustainable and the country has an adequate level of foreign exchange reserves. The Government will continue the policy of a flexible market determined exchange rate regime. Exchange rate interventions will be limited to smoothing short-term volatility and the variability of donor flows, affecting external debt payments and maintaining a sound level of the net international reserves. The Government is committed to making full use of exchange rate flexibility to respond to both medium and long-term exogenous shocks.

\section{Financial Sector Reforms}

The main objective of financial sector reforms is to enhance the environment for private savings and investment, and lower interest rate levels and spreads. The reforms will address poor governance and market structure by establishing a new regulatory framework and enhancing competitiveness.

New regulations will strengthen the supervisory and enforcement capacity of Central Bank of Kenya (CBK) by transferring Banking system licensing, regulatory and disciplinary authority from the Ministry of Finance to the Central Bank of Kenya, tighten provisioning regulations to conform to international best practice and implement anti-money laundering legislation.

To strengthen competition, the government will uphold a financial system with marketdetermined deposit and lending rates, as well as bank charges and commissions. At the same time, the government will implement measures to ease cost pressures on the sector, including 
supporting secured transactions, lowering credit risk, improving borrower accountability, encouraging establishment of credit bureaus and endeavouring to reduce the stock of nonperforming loans (NPLs). Reforms will be geared towards strengthening Deposit Protection Fund to enhance depositors protection including: i) Preparation of a new Deposit Protection Fund act, ii) Implementation of capacity building in workouts and workout management techniques, and iii) Liquidation of distressed small banks. The Government will divest from commercial banking operations starting with the restructuring and privatisation of National Bank of Kenya to be completed by December 2005. Other banks like Kenya Commercial Bank require limited state intervention since the bank's management is resolving the problems facing the bank. The government will support the bank's right issue so as to improve its capitalisation.

Following the outcome of a recent study on reforms in the banking sector, the government is reviewing several options regarding state bank's restructuring and privatisation. These options are:

- Partial restructuring of the Banks

- Full restructuring of the Bank

- Immediate sale of the bank to a strategic investor

- Allowing the institution to resolve problems on its own.

The government also intends to reform Development Finance Institutions especially the ones owned by Government and in poor financial condition. These institutions, which provide financial services to specific groups and certain sectors of the economy, have large share of nonperforming loans in their loans portfolio, which have been accumulated as a result of poor institutional capacity in assessing client creditworthiness. They have also been susceptible to political interference. The Government has commissioned a study with World Bank support, which will clearly define the role and propose reforms necessary for development finance institutions.

The Government's reform agenda places much emphasis on provision of targeted credit to strategically important sectors, such as agriculture and SMEs. As a short-term measure, the government has already taken the first step to revive Kenya's Development Finance Institutions by providing new capital to the Agricultural Finance Corporation (AFC).

The government appreciates that DFIs require a more comprehensive reform program, particularly for institutions such as IDB, KIE and KTDC. These institutions are deeply troubled financially and would need substantial injection of funds for them to operate effectively.

Key reforms needed in these institutions include:

- Development of a national policy on access to financial services, development finance and micro finance.

- $\quad$ Provide a framework for proper supervision of the institutions

- Designing a strategy for development financing that minimises the adverse effects on private financial intermediaries.

As part of the reforms in the financial sector, the government is in the process of developing the legal framework to regulate micro finance institutions and SACCOs. This will improve access to credit by SME and form the basis for any future reforms. Once the legal framework is in place, 
large SACCOs effectively collecting deposits from the public and with Front Office Service Areas (FOSA) will be subjected to rigorous licensing standards and prudential regulations by the Central Bank. This will help to avoid possible misperception about the status of non-supervised SACCOs compared to that of banks and reduce risk of regulatory arbitrage. There is need to undertake more extensive work on access to financial services, particularly with respect to measures that would facilitate improving access to credit by the rural population, farming households, and on the present and future role of existing DFIs.

The reforms will also involve undertaking a comprehensive mapping exercise to estimate the demand and supply by different categories of borrowers in different geographical locations so as to identify gaps in service delivery to different segments of population. This exercise will eventually help in the formulation of a national policy on access to financial services and will be used by the government to develop and secure consensus on a coherent national policy and strategy for micro and small business finance which clearly defines the respective roles of the Government, micro and SME finance stakeholders in providing and broadening access to basic financial services.

Institutions like Kenya Post Office Saving Bank, which have wide outlet network, have a potential to be used to expand linkages between the micro finance sector and the banking sector. This will enable micro finance providers to take advantage of the physical presence of KPOSB outlets for the transfer of funds to their accounts with their clearing banks.

Financial requirements for the reforms are expected to come from the financial sector adjustment credit that will be financed by the World Bank.

In other areas, the Government is preparing pension reforms, designing a comprehensive strategy for insurance services market development and reforming capital markets including the establishment of a central depository system, the strengthening of disclosure rules, and the introduction of second tier market to enhance medium sized firms' access to capital markets.

The pension reforms specifically target introducing a contributory pension scheme for civil servants in the year 2004/2005. Other reforms in the pension department are aimed at improving claims settlement procedures. Legislation has already been passed in parliament that will ensure that claims are settled within 30 days after retirement.

\section{Infrastructure}

The ERS identifies infrastructure as one of the main pillars of Kenya's economic recovery program. Modern infrastructure is viewed as critical to lower the costs of doing business and increase the competitiveness of Kenyan products on the international markets. Developmental objectives include an expanded and well-maintained road network, improved safety of urban transport, increased access to water resources, increased availability, reliability and affordability of energy, efficient telecommunications services and a vibrant information technology sector.

To increase efficiency of investment in infrastructure, the government plans to significantly increase private sector participation and investment. Pillars of this strategy include the development of a satisfactory regulatory and legal framework, and the transfer of key operations to the private sector within the government's overall privatization and competition frameworks. 


\section{Regulatory and competitive frameworks}

The main objective of developing new regulatory and competitive frameworks for infrastructure is the provision of an environment conducive to private sector participation while at the same time ensuring competitive practices that will deliver greater access and affordability to final users. Toward this end, the government has initiated action to review regulatory arrangements in infrastructure sectors, and assess the viability of establishing a multi-sector independent regulatory agency and/or strengthen the regulatory capacity of existing agencies (e.g., telecommunication and energy sectors). The government is also committed to enact the Water Act 2002 and the new Investment Code, and amend the Electric Power Act, the Petroleum Act, Kenya Roads Board Act, and the Monopolies and Price Control Act.

\section{Privatization}

The Kenya Government considers privatization as an integral part of the public sector reforms required to spur the recovery of the economy. In this respect, a number of privatization measures are scheduled to be implemented as part of the country's economic recovery strategy. These measures are outlined in a draft privatization strategy which is currently being finalized for submission to the cabinet.

The legal and institutional framework for implementing the strategy is in the Privatization Bill approved by the Cabinet in June last year, published in the Kenya Gazette on 7th November 2003 and read in Parliament (First Reading) in December. Once the bill is enacted it will entrench the privatization process in the law and provide for establishment of the Privatization Commission.

The privatization program will include several modalities for private sector participation in water, energy, roads, transport, and communications. It is targeting key utilities and infrastructure service providers that are either the main providers in their sector or represent large portions of the market. Major candidates for privatization/private sector participation in infrastructure include Telkom Kenya Ltd (TKL), Kenya Railways Corporation (KRC), Kenya Power and Lighting Company (KPLC), KenGen, Kenya Ports Authority, and road financing, management and maintenance works (e.g. Mombasa-Nairobi North Corridor Road).

The Cabinet approved and sent to Parliament the Privatization Bill, which will establish a strong privatization commission and pave the way for a transparent and accountable process of privatization. The Privatization Bill is being complemented by the reform of sector-specific legislative frameworks to facilitate private sector participation.

\section{Water and sanitation}

The government is implementing structural reforms to make water and sanitation services autonomous, mobilize investment for construction and rehabilitation, and enter into partnerships with community based organizations to expand services to urban poor and rural communities. Implementation of the Water Act 2002 entails the establishment of Water Service Boards, the Water Services Regulatory Board and the Water Services Trust Fund, as well as the transfer of water assets from the Ministry of Water to the Water Boards (Kenya Gazette notice, 18th March 
2003). These institutions effectively separate the functions of policy formulation, service delivery and regulation of the water and sanitation sector.

The reform will increase availability of national fresh water resources from the current level of 247 cubic meters per capita to 900 cubic meters per capita by 2007. Specific targets include: i) 200 hydrological and quality water monitoring stations will be rehabilitated country-wide; ii) 1,200 water samples analyzed per year; iii) unaccounted water wastage reduced from 60 percent in 2003 to 25 percent in 2005 through rehabilitation/augmentation of urban water supply and sewerage schemes in Nairobi and Mombasa; iv) 30 rural water supply schemes in 2003, 90 in 2004, 180 in 2005, and 300 in 2006 rehabilitated and handed over to local level management; v) 100 small dams and water pans rehabilitated and handed over to communities per year; and vi) 500 boreholes drilled and equipped/rehabilitated and handed over to local communities per year.

The financing requirement for the water and sanitation programmes was estimated at Kshs 24.5 billion between 2003 and 2005. Out of this the cost of priority programmes will total Kshs 14.3 billion.

\section{Roads}

The road sector is a priority in the ERS as it greatly affects the cost of doing business and marketing potential for Kenyan products. The sector objectives are to expand the road network, reduce the rehabilitation and maintenance backlog, strengthen road safety and control overloading, and expand private sector management and financing. The government is formulating a long-term road sector strategy, and will consider a multi-agency model for managing responsibilities and financing for trunk roads, highways, park roads and rural roads. On the latter, the government is rationalizing the number of agents responsible for rehabilitation, construction and development of urban roads under the Kenya Roads Board (KRB) Act. The government is completing a road inventory and condition survey study, reducing the audit backlog for the road levy fund and improving public information on the use of the fund, considering the establishment of a new road safety authority, enforcing axle load control limits, and launching a national road safety campaign.

The centrepiece of the strategy is an accelerated timetable for concessioning major roads' construction and maintenance to the private sector. The study on Road Concession (phase 2) was completed in June 2003. Based on the assessments done conventional tolling is proposed for the 1,208 kilometres of the Northern Corridor. Three viable road concessions have been identified. These are (i) Mombasa - Machakos, (ii) Machakos-Rironi, and (iii) Rironi to Malaba via Eldoret and to Busia via Kisumu. The government has taken a firm decision to move ahead with the preparatory work on Roads Concessioning Framework by preparing the regulatory and legal instruments to allow for concessioning. Concessioning will start with the Machakos Turn OffNairobi Southern Bypass section of the Northern Corridor under BOT arrangements. This phased approach will test the willingness of the road users to pay. At the moment, significant financing is available from donors (US\$ 309.4 million for rehabilitation of about $500 \mathrm{Km}$ of the Northern Corridor). Further financing is expected to come from interested investors (US\$ 326.7 million for $641 \mathrm{~km}$ of road).

To address rural road maintenance and improvement, the government is implementing the Roads 2000 programme in 26 districts so far, with the participation of local communities and labourintensive local contractors. Several donors (European Union, SIDA, DANIDA, ADB, AFD and 
KfW) are supporting this program and expected to finance significant portions of it. The challenge is to adopt this programme countrywide.

Selected targets over the planned period include: Roads 2000 programme expected to rehabilitate $2,815 \mathrm{~km}$ and create 18,800 jobs; reconstruction of $150 \mathrm{~km}$ of trunk roads per annum; and concessioning up to $1,208 \mathrm{~km}$ of trunk road during 2004-07.

\section{Transport}

Transport services greatly affect the competitiveness of Kenya goods. Reforms are geared toward improving the management and security of transport infrastructure.

\section{Railway transport}

The government will complete the ongoing process of concessioning Kenya Railways Corporation by means of a long-term concession covering passengers and cargo operations. The concessioning process has been extended to include joint concessioning with the Uganda Railways. The concessionaire is expected to be in place in 2005. This will assist to raise investment funds necessary to improve rail services.

\section{Air transport}

Kenya is the major airline hub in East Africa. Its air transport services have facilitated and will continue to sustain development in sectors such as trade and tourism. Efficient and secure air transport is therefore one of the ERS priorities for economic growth. While air transport services were liberalized in 1996 with the privatization of Kenya Airways, airports management has remained in the hands of the state under the Kenya Airport Authority (KAA) and performed below potential. A Civil Aviation Authority was established in 2002 to regulate aviation activities and improve air traffic control. Airport management, safety and security under KAA remain weak. Reform objectives include raising airport security and safety service levels to international standards, improving airport facilities, management and operations, and lowering operating costs.

The first priority is to address security concerns, and enhance the security and safety service levels to attain the Federal Aviation Authority/International Civil Aviation Organization Category 1 standards from the current Category 2. Attaining Category 1 status will allow direct flight to the US from JKIA, strengthen Kenya's competitive position as the regional airport hub, and Kenya Airways to compete with other airlines. This will require significant refurbishing of airport facilities, investment in security equipment and safety facilities, and training. Already, the government decided to reorganize the passenger terminal at JKIA to separate arrivals from departures and relocate the domestic terminal (terminal 3) to the Old Airport at Embakasi in an effort to provide additional space for the international flights.

Second, a study funded by PPIAF will be undertaken to determine PSP options in the management and financing airport activities in Kenya. Accordingly, the Kenya Airport Authority Act and the Kenya Civil Aviation Authority Act, which currently allow for private sector management of only commercial activities (aircraft landing services, and cargo handling), will be amended to allow for private sector management or concession of the airports. 
Finally, airport charges, currently above those charged by competing regional airports, will be reviewed and harmonized accordingly. Alternative mechanisms to finance airport infrastructure are under review, including expanding commercial activities on airport grounds and reviewing current commercial concessions.

\section{Maritime and inland waterways}

Managed by Kenya Ports Authority (KPA), the port of Mombasa is one of the main ports on the east coast of Africa, serving the whole of Kenya and land-locked countries such as Uganda, Burundi and Rwanda. To maintain its competitive edge, the government is putting Mombasa Port on an accelerated reform schedule to convert it to a landlord port. The landlord port is the most widely-used model for introducing private provision of services into port operations. Under this model, key infrastructure facilities will remain under KPA ownership.

A new Maritime Sector Policy Paper is being prepared. The policy proposes the creation of a Maritime Authority responsible for the regulation of all marine and maritime affairs. The office of the Coast Guard will be placed under the KPA to manage maritime and port facility security. Other measures will include a reform of all clearances affecting passage of goods through the port and streamlining of customs procedures to improve transparency and reducing time and costs.

The Kenya Ferry Services is operated as Public Service Obligation (PSO) by the Government to enable pedestrians who work in town to cross the channel on a daily basis. The Ferries have outlived their economic life and are a hazard to users. Since FY 2002/03 Kenya Ferry Services (KFS) has been implementing two government funded projects. These are the construction of maintenance facilities for above water maintenance and for overnight stay (Ksh58 million in 2002/03 and Ksh100 million in 2003/04), and the expansion of walkway terminus (Kshs 14 million in 2001/02). The KFS proposes to purchase two ferries at a cost of Kshs 600 million to replace MV Pwani (1975) and MV Mvita (1969), which have outlived their life span.

\section{Communications and information}

\section{Telecommunications}

The government recognizes the urgent need to open the doors for a major expansion of the telecommunications sector as one of the necessary conditions for accelerating growth in other productive sector of the economy. The poor performance of the fixed-line telecom sector has been due to inefficiency and monopolistic structure in the sector. For example, only 2 percent of household have fixed lines, 60 percent of them located in the Nairobi area; and waiting time for new lines is eight years. While Telkom Kenya's current monopoly license runs to 2004, the government has taken steps to respond to service failures on the part of the monopoly. Communications Commission of Kenya (CCK) will move quickly to introduce competition in the international segment, which will induce Telkom Kenya to lower rates for international calls; it will go ahead and license other operators of fixed (local) telephone services outside Nairobi, as soon as the rural access study currently being undertaken in collaboration with the International Development Research Centre and CCK is completed; and it has allowed other operators to provide public payphone services and inter-corporate data exchange. Towards this end the bidding process for the second national operator has already commenced. In the meantime, the government is preparing a privatization strategy for Telkom Kenya that will maximize the growth prospects for the sector. 
In the mobile phone sector, competition between Safaricom and Kencell, introduced since 1999, has significantly expanded access to telecommunications services to about 2.2 million subscribers. Yet cross-subsidization schemes by Telkom with its subsidiary Safaricom have kept cellular phone rates high. To increase subscriber base, widen geographical coverage, lower consumer rates and expand job opportunities CCK by end 2003 completed the bidding process for the licensing of the third cellular phone operator. However, the issuing of the license has been delayed by a case filed in court by one of the bidders challenging the award.

Internet service provision is fully liberalized and the CCK has so far licensed over 60 Internet Service Providers and about 31 of these are in operation. More potential exists in this area for exploitation by the private sector especially outside Nairobi and Mombasa, and in lowering costs.

Other initiatives include reviewing the Telecommunications and Postal Sector Policy in view of the expiration of Telkom Kenya's license in June 2004; withdrawing idle broadcast frequencies and reallocating them under a transparent, equitable regime; and supporting the development of a submarine cable on the east coast of Kenya linking to cables to the south and the north of the region to reduce data transport costs in the long term.

\section{Information and communications technology}

The Government recognizes the importance of Information and Communications Technology(ICT) for improving performance in the productive sectors and Government, and as a potentially fast growing and employment generating industry. The sector has been hampered by low access to telecommunication, limited penetration of ICT usage in Kenya especially in the rural areas and inadequate legislative framework.

In order to achieve rapid growth in the sector, the Government has consulted widely with major stakeholders and these consultations have culminated in the finalization of an ICT policy. The Stakeholders included, Private Sector, Civil Society, Internet Service Providers(ISPs), manufacturers of ICT equipment, International agencies and Development Partners. The ICT policy has received Cabinet approval is scheduled for full implementation. It provides guidance for the operationalisation and management of internet technology, Communications and Radio/TV.

To facilitate the smooth implementation of the ICT policy, the Government has liberalized the telecommunications sector by removing the monopoly hitherto enjoyed by Kenya Telecommunications Corporation. In this regard, the Government has licensed a second telecommunications provider to ensure vigorous competition in the provision of telephony.

Other critical measures will include the following: -

(i) Invest in adequate ICT education and training. In this context, the Government will streamline the education curriculum to incorporate IT studies to develop appropriate skill requirements.

(ii) Implement a well targeted tax reduction and/or tax incectives on both computer software and hardware to make them affordable to micro enterprises and low income earners.

(iii) Removal the impediments that have discouraged adoption and use of e-commerce. 
The Government will also complete the implementation of e-government by June 2004. This will include the use of information technologies such as Wide Area Networks, internets, and mobile computing by Government agencies in order to improve effectiveness, efficiency, service delivery and promote democracy. E-government will enable citizens to access Government services and information as efficiently and as effectively as possible through the use of internet and other channels of communication. Specifically the Government will: -

(i) Improve collaboration between Government agencies through reduction of duplication of efforts, enhanced efficiency and effectiveness of resource utilization.

(ii) Reduce transaction costs incurred by the government, citizens and the private sector through provision of products and services electronically; and

(iii) Provide a forum for citizens' participation in Government activities through opinion polls, surveys on Government policy and administrative direction.

To ensure proper coordination and timely implementation of the above, the Government has constituted a technical steering committee to work closely with the National Economic and Social Council (NESC), to mainstream ICT into government operations. This streamlining will entail building the government information infrastructure, implementing the Government Information Technology Investment Management (GITIM). Phase I of this Government information infrastructure component is in the process of installing structured cabling in all central government buildings. Phase II will extend connectivity of district offices. GITIM implementation will develop and enforce ICT standards, guidelines and principles that will guide the management of information technology resources within the public service. The focus of egovernment efforts will be to improve government back-office functions, develop public services to be delivered through the internet, develop modalities for acceptance of electronic documents for instance by KRA, foster interactions with large businesses, and post key information to improve transparency. The technical steering committee in charge of the formulation of a national ICT policy will also oversee the development the e-government.

\section{Goals of e-government in Kenya}

The achievement of an e-Government is one of the main priorities of the Government towards the realisation of national development goals and objectives for Wealth and Employment Creation. An effective and operational e-Government will facilitate better and efficient delivery of information and services to the citizens, promote productivity among public servants, encourage participation of citizens in Government and empower all Kenyans. To this end, the Government is committed to establishing e-Government by June 2004.

The e-Government Strategy objectives aim at: enhancement of transparency, accountability and governance; making the Government more result oriented, efficient and citizen centred; and enabling citizens and business to access Government Services and Information as efficiently and as effectively as possible through the use of internet and other channels of communication.

The effective and efficient realisation of e-Government objectives depends on the availability of skills and the right attitudes across Government. The Government personnel at all levels will be adequately equipped through relevant training to effectively carry out this initiative. This calls for a change in the way Government carries out its operations and requires training in change 
management. In order to ensure a continued pool of IT knowledge base within Government, all training programmes will have an IT component.

The objectives of e-government include to

a. Improve collaboration between Government agencies through reduction of duplication of efforts and enhanced efficiency and effectiveness of resource utilization;

b. Improve Kenya's competitiveness by providing timely information and efficient delivery of Government services;

c. Reduce transaction costs incurred by the Government, citizens and the private sector through provision of products and services electronically; and

d. Provide a forum for citizens' participation in Government activities through opinion polls, surveys on Government policy direction, etc.

The targets for June 2004 are:

a. Develop and implement e-Government Strategy for Kenya.

b. Establish an appropriate institutional set-up for e-Government.

c. Undertake an inventory of ICT capacity and assets within Government.

d. Sensitize all Government Officials on the e-Government Strategy to develop consensus and a common understanding of its implementation.

e. Establish a Directorate of e-Government to coordinate the implementation of the Strategy and ensure security of Government systems and information.

f. Continue with cabling of Government Buildings.

g. Increase internal operational efficiency and effectiveness by fully implementing systems as the Integrated Financial Management System (IFMIS) and the Integrated Personnel and Payroll Database (IPPD) systems which are already underway.

h. Harmonise all Ministry websites in a single Government Portal and create email addresses for all civil servants to ease access to Government information and improve communication.

i. Undertake capacity building by training the core implementation team on computer literacy and web-based applications and internet use.

The medium term targets are

a. Train all civil servants on computer literacy and web-based applications and internet use.

b. Operationalise email addresses for all civil servants. 
c. Implement an integrated system for registration of persons including births and deaths; immigration; property and assets registration systems including land and motor-vehicles; and implement integrated taxation databases and information systems e.tc.

d. Complete the implementation of messaging and collaboration services to facilitate the exchange of mail among discussion groups and calendaring of events across a common platform.

e. Roll-out the information infrastructure to district offices.

f. Accelerate automation and integration of Government information and records.

g. Operationalise web-enabled databases and expedite data sharing and document workflow within government.

Other targets include

a. Introduce e-talking to citizens by providing citizens with Government publications such the Kenya gazette, laws and regulations, immigration forms, passport application form e.t.c through websites;

b. Enhance listening to citizens by increasing the input of citizens into public sector decisions and actions;

c. Enhance e-policing so that a traffic policeman could for example access electronically details of a car or driver at the event of an accident;

d. Enhance the provision of election services online such as e-voting to ensure that there is no congestion at polling halls and that vote counting is done quickly; and

e. Introduce an electronic payment system to enable payments of utility bills electronically.

Implementation of e-government is, however, faced with several challenges including

a. Accomplishing the targets for June 2004 requires Kshs.100 million which is yet to be provided by Treasury.

b. Financial Resources - It is estimated that kshs.500 million for equipment, connectivity, training e.t.c will be required annually for the next five years for the successful realisation of e-Government.

c. Human resources - All civil servants will need to be trained to ensure adequate capacity in the use of internet, email and e-Government applications.

d. Right attitudes - An e-Government requires a change in attitudes, cultures and norms. Civil Service Reform is key to the continued implementation of e-Government.

e. Enabling Legal and Regulatory environment - the legal framework must be reviewed to enable handling of Government records and information electronically and to ensure the security and integrity of information. 
f. Sustained Championing of e-Government is necessary at the highest level of Government to ensure focus and commitment to the realisation of e-Government objectives.

\section{Energy}

Electricity

The electric sector is in urgent need to deepen reforms to enhance reliability of service supply, increase access to electricity, and lower energy costs. Expanded private sector participation in generation and distribution of electricity is at the heart of the agenda. To achieve this, the government will further legislative reforms and strengthen regulatory functions of the Electricity Regulatory Board (ERB) including a review of the existing tariff regime and the methodology for setting tariffs; reduce its direct equity in the Kenya Power and Lighting Company (KPLC) from 51 percent to below 39 percent in order to remove it from the purview of the State Corporation's Act; and restructure Kenya Electricity Generating Company (KenGen) to enable a public private partnership necessary to mobilize the investment needed for expanding generation capacity. A cabinet paper on the recovery programme of KPLC was prepared and presented to Parliament and has undergone through the second reading.

To accelerate the pace of rural electrification, the government will streamline the current institutional arrangements for the implementation of the rural electrification programme by creating a special body, the Rural Electrification Authority (REA), under the Electric Power Act, 1997. The aim of the government is to reach a penetration rate of at least 40 per cent of the rural population by 2020 from the current 4 per cent. The government is aware of the high costs of new connections under rural electrification (currently KSh 180,000 per rural consumer or 8 times per capita income in 2000), and will be investigating more efficient new connection arrangements alternatives.

\section{Petroleum}

The petroleum sector lacks an effective regulatory framework. It suffers from poor competition, enforcement of safety standards and high barriers to entry. The government has prepared a new Energy Act that combines the Petroleum Act and Electricity Act for ease of administration. This is expected to significantly improve service delivery and expand the existing facilities including financing and management modalities on the extension of the oil pipeline from Eldoret to Kampala.

\section{New and renewable energy}

While the country has significant energy resources, including hydropower, geothermal, solar, wind and biomass, biomass (mainly wood fuels) accounts for over 70 percent of total energy consumption, 80 percent of the population depending on it their domestic energy needs. The use of woodfuel has been responsible for significant deforestation and the government is committed to reverse this trend in favour of a policy promoting sustainable wood resource management and efficient harvesting, and end-use technologies.

The government is also committed to harnessing traditionally underutilized solar energy in various applications including alternative grid extension for electricity provision, telecommunications repeater facilities, water heating, crops drying, refrigeration, and water pumping. Solar energy usage is very small relative to its potential. Only about 150,000 
photovoltaic home systems are currently in use in the country with an expected yearly increase of about 20,000 units. The government in partnership with the private sector and NGOs will develop a framework to provide incentives for solar energy users. Increasing the rate of adoption to 50,000 units would deliver energy savings of about 150,000 tonnes of oil equivalent or US\$ 30 million annually at current oil prices.

The government is supporting initiatives to popularize wind power (now contributing only about 0.2 million KWH to the national grid). Technological development has made wind powering increasingly more attractive especially to remote areas with no access to electric energy and oil supply outlets. Applications include battery charging, water lifting, small hydropower systems and power supply to community centres and health clinics. Major constraints are: lack of appropriate technology, absence of data regimes and poor promotion strategies.

\section{Productive Sectors}

The main drivers of the Kenyan economy are tourism, manufacturing and trade. They contribute 25 percent of Gross Domestic Product and employ 4 million people, of which more than 90 percent are in the informal sector. The government is committed to improving the environment for private sector growth and investment in these sectors, mainly by removing barriers to investment and lowering the cost of business.

\section{Tourism}

Tourism plays a central role in the Kenyan economy and is a major source of potential growth and employment generation. As such, the government is committed to working with the private sector in removing the hindrances to its growth, and strengthening the linkages between tourism and the rest of the economy. To do so, government organizations (Kenya Tourism Board, Wildlife Service, the Tourism Development Corporation and the Hotel \& Restaurant Authority) will work hand-in-hand with a wide range of representatives from the private sector (Kenya Tourism Foundation, its member groups, and other stakeholders) to develop and implement a coordinated strategy for revamping the sector (tourism development policy and plan). The strategy will address the need to attract tourists from a wider range of countries, diversifying tourist attractions, expanding the benefits to the local population, protecting the environment, and improving quality and standards.

The main concern the government is addressing is security. The medium-term strategy includes a full reform of security forces (see governance), and the strengthening of airport security (see infrastructure). As an interim measure, the government is instituting tourist and anti-terrorist police units, to improve security in the surroundings of hotels and resorts.

To improve competitiveness of the Kenya relative to other tourist destinations, the government will be reviewing the structure of taxation in the sector (which currently results in a 22 percent average tax on tourist spending), and providing tax incentives for tourism infrastructure refurbishment.

To improve marketing of Kenyan destinations, the government has strengthened the Kenya Tourist Board, which together with the Ministry of Information and Tourism and the Kenya Wildlife Service will embark in a major promotion campaign and improve information systems. The promotion exercise is intended to market the diversity of attractions available in Kenya, to 
include eco-, conference, sports, retirement, film industry and domestic tourism. The budget for this activity is however severely limited relative to that available to Kenyan competitors, and will need to be expanded either by earmarking selected tourism revenues or expanding private sector contributions.

To strengthen the linkages with the rest of the economy and make tourism pro-poor, efforts will be made to: foster community-based and eco-tourism particularly to northern and western areas of the country and targeted to backpackers and nationals; strengthen community-based wildlife conservation, adopt an appropriate compensation policy and take measured to reduce humanwildlife conflicts; provide guidance, access to credit, and incentives to small and medium enterprises; and review the structure park tariffs to expand tourism on less-visited parks. The Kenya Tourist Development Corporation (KTDC) will be restructured to play a key role in facilitating local investment and proving credit to small and medium enterprises.

For environmental protection, the government, in partnership with the private sector and communities, will focus on land management. Elements of land management include an integrated costal zone management structure to oversee development in Mombasa and Malindi; government-private-community partnerships to extend reserve areas around national parks; local community involvement in designing and implementing plans for sustainable land use management as part of the National Environment Management Act, modelled after the Selenkay Conservation Area experience; and certification schemes for eco-friendly resorts.

Finally, to address quality and standards, the government plans to: expand the facilities of Kenya Utalii College, including reviewing the proposal for establishing an additional branch in the coastal region by July 2005; and enhance the role of the Catering Levy and Development Trustees (CTLDT) to provide affordable credit to local tourism operators and a regulatory framework for the standardization of training in the sector.

\section{Trade and investment}

As a result of early 1990s trade liberalization reforms, price and exchange rate restrictions have been eliminated, tariffs lowered, and suspended duties scrapped, giving Kenya a high rank for openness. The government has also recently embarked on a comprehensive reform of its trade system within the context of the Common Market for Eastern and Southern Africa (COMESA) and the East African Community (EAC). By 2004, Kenya will reduce the number of nonzero tariff bands to four, the top tariff rate to 25 percent, and the duty on raw materials and capital goods. It will also build capacity to address trade disputes and dumping claims, and harmonize investment incentives.

To increase trade and investment performance, the government will review licensing agreements, provide market information to Kenyan manufacturers, and support the private sector in identifying new markets, improving quality of Kenyan goods, reducing non-commercial risks, organizing export trade fairs, and exploiting AGOA. A sessional paper on trade policy will be completed by the Ministry of Trade by September 2004. The World Bank and other partners are assisting the government carry out a trade diagnostic study, expected to be completed by June 2004.

To increase foreign investment, the government will work to improve the business climate and speeding up privatization. Measures include developing a new regulatory framework for finance and infrastructure, strengthening the rule of law, improving security, and reducing the number of 
regulations and steps required for investing in the country. The government drafted a new Investment Code, which, among others, entails the establishment of an Investment Authority in charge of investment policy and the development of an investment roadmap by 2005 .

\section{Industry}

Kenya's manufacturing sector is performing better than its neighbours but still well below its potential. To expand its growth and employment generating capacity, the government will focus on removing the barriers to investment and lowering the cost of business in the sector. This will include measures to further liberalize trade, deepen the financial market, enhance infrastructure, improve security, facilitate use of technology licenses, review mechanisms for wage determination, and improve access to quality training.

Many of these activities will require close coordination with other sectors (trade, finance, infrastructure, justice, and labour) to ensure that reforms in those sectors are consistent and supportive of labour-intensive growth in manufacturing. Even more importantly, the government will ensure the existence of adequate mechanisms for private sector consultation to ensure that policies address the heart of private sector concerns. To this end, the government will be preparing, in consultation with its private sector partners, an industrial master plan to operationalize the sessional paper on industrial transformation. In addition, the government will undertake benchmarking exercises for key industries, including sugar and textiles, to measure Kenyan industries' competitiveness in the international market and identify constraints to improved productivity. 


\section{Chapter 4: Equity and Poverty Reduction}

\section{Human Resources Development}

Human resource development is at the core of the ERS strategy to level the playing field and provide opportunities for all Kenyans to productively and self-reliantly participate in employment and wealth creation. Developing human resources requires complementary efforts in education and training, health and HIV/AIDS, labour and nutrition.

\section{Education: attainment of universal primary education}

Education, and particularly primary education, is the top priority on the NARC Government agenda. The government's first policy action in January 2003 was to institute free primary education. As a result, enrolment has increased by 1.5 million children in 2003 . To strengthen the education system and ensure proper linkages at various levels the government is negotiating with the donors a comprehensive education sector program and a national forum on education was held in November 2003. Program priorities include ensuring equitable enrolment by targeting disadvantaged areas, particularly ASAL areas and urban areas, and vulnerable groups, such as girl child, street children, etc; improving quality and internal efficiency through teacher training and redeployment, reforming the curriculum to focus on core skills, providing teaching and learning materials and improving the learning environment, redefining the roles of local authorities, and decentralizing decision-making to district and school-level administrators, and parents' representatives.

To sustain and motivate participation and completion in primary schools as well as to improve transition levels efforts will also be made to enhance secondary schools capacity in order to accommodate more primary school graduates.

The free primary education program implementation has necessitated increases in both recurrent and development expenditures. However, making public resource utilization more efficient is now a priority without which the attainment of universal primary education could remain elusive.

\section{Health: provision of basic health services}

The primary objective of the health sector reform process is to enhance accessibility and affordability of quality basic health services for all Kenyans with special emphasis on the poor and vulnerable. Formidable challenges in the sector make the achievement of this objective an uphill task. These include the emergence and re-emergence of some diseases such as HIV/AIDS, tuberculosis and drug-resistant malaria, which have increased the disease burden, and the increasing poverty levels. This has led to an overburdened health sector, ever-increasing costs of essential inputs for medical supplies as well as human resources, and a decreased capacity to financially contribute to the cost of health care by the majority of Kenyans. As in education, the labour and skill-intensive nature of health services leads to most of the resources going to wages and leaving very little for non-wage recurrent expenditures and capital inputs.

In order to face these challenges the Ministry of Health aims to achieve the following reforms and targets: 
Revisit the financing of the health sector. The objective is to reduce the unaffordable level of out-of-pocket expenditures by the poor and vulnerable and to protect them from financially catastrophic expenditures for health care services. The government is committed to the introduction of a social health insurance scheme, to achieve the objective of making health affordable. The strategy envisages a phased approach to ultimately achieve national coverage in the medium term.

Focus its investments on interventions that will in particular benefit the poor and vulnerable. The Ministry of Health will step up the efforts to increase the immunization coverage to 85 percent, reduce the children under five years mortality rate to around 100/1,000 by 2008 , reduce the maternal mortality rate from $590 / 100,000$ to $560 / 100,000$ by 2005 , reduce the HIV prevalence rate by 10 percent, increase the accessibility and availability of essential drugs, reduce the mortality rate for malaria by 10 percent annually, increase the cure rate for tuberculosis, and improve health service delivery for the underprivileged rural and urban slums. In order to achieve this the ministry will re-allocate resources towards promotive, preventive and basic health services and enlist additional capacity through partnerships with civil society, faith based, and private sector organizations.

Improve cross-sectoral cooperation for health promotion and public health, especially to achieve public health standards that are currently not realized for the poor. In view of the importance and critical roles that other sectors play in achieving better health outcomes, the ministry will strengthen its ties and collaboration across sectors in the areas of water and sanitation, reproductive health, gender, HIV/AIDS, nutrition, school health, road safety and tobacco control.

Increase the efficiency and effectiveness of the combined investments of GoK and its partners. In order to achieve synergy and reduce inefficiencies related to independent and fragmented efforts, the Ministry of Health will further pursue the modalities that allow a programmatic approach by all partners involved. These include a jointly agreed National Health Sector Strategic Plan, a jointly agreed and supported monitoring and evaluation framework, mechanisms for annual health sector program reviews, a jointly agreed and supported medium term expenditure framework, and an annual sectoral public expenditure review to evaluate the effectiveness of actual expenditures against the objectives of the health sector program.

Increase total government spending on health from the current 5.6 percent as a share of total public expenditure to 12 percent over the time period of this investment program. Such an increase in the investments in human capital may seem ambitious, but past public spending per capita on health in Kenya has significantly lagged behind as compared to global and regional experiences. In addition, the challenges described and the commitment of the government to make significant progress towards the Millennium Development Goals justify such an increase.

\section{HIV/AIDS}

The government is implementing a comprehensive multi-sectoral national strategy in the fight against HIV/AIDS (National Strategic Plan on HIV/AIDS, 2002-2005). The strategy includes institutional, legal and programmatic reforms. To strengthen policy formulation and oversight, the government has established a cabinet sub-committee on HIV/AIDS, chaired by the President, and is in the process of restructuring the National AIDS Control Council (NACC). To provide for an explicit legal framework for the national response to the HIV pandemic, the government recently promulgated a bill on HIV/AIDS. At the programmatic level, the government 
implemented a new policy on decentralization to focus attention on the need to strengthen action at the community level, with the constituencies serving as the focal points. At the same time the government is committed to continue its focus on the prevention of new HIV infections among the 90 percent of Kenyans who are not infected. In order to achieve this, the government plans to pay particular attention to the empowerment and protection of the most vulnerable. The government recognizes that vulnerability factors for HIV infection, including those related to poverty, gender, discrimination, educational attainment and socio-cultural factors, are diverse and complex and can only be coherently addressed when the multi-sectoral dimensions of the response to HIV/AIDS are significantly strengthened. The government also plans to intensify advocacy campaigns and education to mitigate stigma and discrimination; coordinate the strategies for prevention, treatment and mitigation; develop a roll-out plan for the increasing amount of resources devoted to treatment; intensify prevention activities; develop capacity building plans for private and public agencies involved in HIV/AIDS programs; and develop a creative and strategic approach for caring for and supporting the rapidly increasing number of orphans. For the infected, the government is committed to availing Anti-retroviral drugs(ARVs) to an increasing number in line with WHO goals. It is expected that nearly 110,000 will have been put under ARVs by the end of 2005.

The government acknowledges the large contribution that development partners and other stakeholders have made in the fight against HIV/AIDS and is committed to maintain an open and productive dialogue with all stakeholders. To this end, the government will reformulate its overall partnership plan that will include modalities for stakeholder participation in the planning and operationalization of new policies, partnership environment for policy dialogue, a jointly agreed strategic plans, jointly supported institutional arrangements, a jointly agreed Monitoring and Evaluation framework, and a Joint HIV/AIDS Programme Review mechanism.

\section{Labour}

The objective of labour reform is to quicken the pace of labour productivity growth. The newly established Productivity Centre of Kenya is expected to implement it's strategic plan with a view to developing a productivity policy as well as productivity measurement mechanisms. In addition the government plans to undertake a study of the labour market to identify a set of consistent recommendations for improving labour productivity, and is seeking donor support for this activity. The study would review the legislative framework; identify the inefficiencies that have led to high unemployment and high labour costs; develop an inventory of available skills and propose reforms to improve labour market flexibility and strengthen the links between education, training and industry demands. In the area of industrial and labour conflict management, the government plans reforms to enhance the dispute settlement machinery, strengthen the tripartite committee secretariat, fortify the labour inspection services, and reduce the backlog of workmen dispute cases.

\section{Labour market policies}

The Government recognizes that the labour management policies must involve a multi-faceted approach consisting of general wages and incomes policy, improvement of working conditions and environment, improving occupational safety and health, clear guidelines on export of labour and employment of foreigners, education and training, and mainstreaming the disadvantaged groups in employment. It's in this respect that the Government has appointed a tripartite Taskforce to review the six core labour Acts and make recommendations for review of all other 
pieces of labour related legislations. The Core Acts are the Employment Act, Regulation of Wages and Conditions of Employment Act, Trade Disputes Act, Trade Unions Act, Factories and other places of work Act, and the Workmen's compensation Act.

The review of these laws is expected to create a better environment for investors and protect the interest of the labour force. The review will also ensure that Kenya domesticates international Standards and Conventions that it is party to, while at the same time meet some of the African Growth and opportunity Act (AGOA) conditionalities relating to freedom of Association, child labour and good governance. Other measures envisaged in the medium term and which are specifically targeted at removing the labour market rigidities and impediments to employment are:

- Developing and orientating Kenya's policies on industrial relations and occupational health and safety programmes.

- Use of productivity indices produced by the newly established Productivity Center, in addition to the traditional in used price indices, in setting the wage guidelines, and in collective bargaining agreements.

- Reorganization and strengthening of the wage setting mechanisms in Kenya including reorganization of labour Advisory Board and wage Councils, quick processing and registration of collective agreements, and allowing market mechanisms to influence wage negotiations.

- Encouraging Tripartism, Social dialogue, and training and research.

\section{Mainstreaming special groups in employment}

Special groups, which refer to women, children, the youth, persons with special needs, retirees and the aged persons face many barriers for entry and progression into a number of socioeconomic activities, and have led to their low participation rates in decent sustainable employment and their optimum utilization.

\section{Women}

Gender disparities in employment opportunities have remained wide in many sectors of the economy. Though women constitute the majority in the labour force their participation remains low relative to those of men. For example, in 1998/99 Labour Force Survey, women participation rate was 72.6 percent compared to 74.7 , percent for men. Factors contributing to these disparities in employment opportunities include negative social attitudes towards women; inadequate capacity on the part of many women in terms of their knowledge and skills; in access to productive resources; and lack of gender responsive policies and programmes. This has led to increased unemployment, underemployment, poverty and powerlessness among many Kenyan women.

To reduce the marginalization of women, the Government policy is to remove barriers and promote the education and training in order improve their effective participation in the labour market. Measures will be put in place to assist women to gain access to more productive resources. These will be through intense sensitization campaigns among key decision-makers in policy and programme implementation positions in various sectors. The Government will further strengthen units of gender issues in various line ministries. 
Government will also institute measures that will prepare and encourage women to compete for all jobs through other appropriate policies and instruments such as promotion of equal employment opportunities and removing limiting clauses of employment related laws that inhibit their effective participation in labour market.

\section{Children}

The Government recognizes the existence of child labour together with employment of young persons in hazardous situations despite of legislations against the same alongside unemployment. Currently it is estimated that Child Labour in Kenya stands at 1.3 million, mainly working in commercial agriculture, fishing and domestic services. This has negative impact not only on the health of the child but also on the country's future labour force. Child labour has been attributed to poverty, HIV/AIDs pandemic and inadequacy in polices to address child labour. The Government however remains committed to protection of children and eradication of child labour.

The main challenge in addressing this problem has been school enrolment, retention, and reintegration of working children back to school. The implementation universal free primary education is a critical initial step in addressing the challenge. The next in line will be secondary education. Complete free education will therefore be one of the effective instruments in attacking poverty and elimination of child labour.

While the Government continues to fight poverty and HIV/AIDs at all fronts, its policy is to develop programmes and schemes that will identify child headed households and children from poor households on a continuous basis and provide for their health needs and social welfare, education and training. The Government has taken encouraging steps through legislations to reduce and eventually eliminate child labour and improve their capacity for implementation and promotion of targeted, pro-poor employment generating projects both in urban and rural areas.

\section{Youth}

The majority of the unemployed are the youth aged 16-39 yrs. The Government appreciates that the problems of increased youth unemployment have been accentuated amidst depressed economy. Lack of skills, assets and access to credit facilities has rendered self-employment difficult for the youth hence leading to high crimes, street begging and drugs. In response the Government is in collaboration with stakeholder developing programmes such as creation and sustention of a revolving youth fund for promotion of self-employment. Other measures will include providing mechanisms to manage transition from school to work, career guidance, industrial attachment, mentoring and couching; and rendering business counseling advisory services.

\section{Agriculture, Livestock and Environment}

With 67 per cent of people living in rural areas, over 50 percent of whom are living in poverty, the agriculture sector is the growth sector, which is most likely to play a central role in reducing poverty and increasing food security. To reverse recent trends of low growth in agriculture, comprehensive and far-reaching reforms must be implemented to promote productivity growth and lower the costs of agricultural inputs, particularly among smallholders and subsistence 
farmers. While smallholder farmers account for 70 percent of marketed agricultural production, their yields are below potential. Tea and coffee yields, for example, are only two-thirds and onehalf that of large farms, respectively. By raising the productivity of these farmers much can be achieved for reducing poverty. It is targeted that average yield of major crops rises by 5 percent over the investment period.

Agricultural research and extension. The objective of reforms in the agricultural research and extension area is to strengthen the link between farmers' demands, extension provision and the direction of research, and increase the productivity of public investment. The government is in the process of restructuring and rationalizing the network of agricultural research institutes by consolidating operations into the Kenya Agricultural Research Institute. Already three out of thirteen institutes have been merged with KARI. The government also plans to open the policy dialogue on the issue of genetically modified seed to investigate the pros and cons of adopting a clear GM policy. In extension, the government will be reviewing alternative modalities for service delivery and exploring modalities for introducing private sector provision. The Government requires support from its development partners for analysing options for greater private sector participation in extension.

Agricultural financial services. One of the main constraints to increased investment in agricultural production is poor farmer access to credit and insurance. The government is interested in investigating and selecting options to deepen the financial credit market for small agricultural borrowers. The rural SACCOs will be expected to enhance their role in mobilizing savings for on-lending to their member farmers.

Agricultural inputs. Price movements in the local agricultural input market do not reflect international market conditions. Between 1997 and 2001, seed and fertilizer prices rose 80 percent, fuel prices 50 percent, and animal feed prices 40 percent. At the same time international prices for inputs declined. Erratic price movements point to serious governance issues in the market for inputs, which have affected investment in agricultural production and farmers' profitability. The government is identifying reforms to improve competition in inputs distribution and marketing and to enforce the law against fraudulent practices of input suppliers and marketing agents. In addition, through the on-going reform in the cooperative movement, the agricultural production and marketing cooperatives will be expected to contribute to improvement in the supply of agricultural inputs at least to their members.

Commercialization. Commercialization of farm and non-farm products is the key for increasing rural incomes. The government activities will focus on reducing transport costs by improving rural roads and reducing fuel taxes; reducing irrigation and factory operating costs by bringing down electricity costs (see section on energy); and improving access to market information by strengthening communications.

Marketing and value addition. Lack of market for products has led to losses of income by farmers and investors in the sector. By adopting appropriate marketing strategies, the government, the private sector and the farmers' organisations can improve incomes and promote economic growth. Some of these strategies include processing, packaging, storage, transportation and research. In this regard the government is committed to supporting cooperative, private investors and other institutions to undertake necessary investments in these activities including market information and dissemination. 
Land administration. The government will formulate a national land policy to address land use and administration, land tenure, and land delivery systems. Modernization of land information management systems is ongoing.

Gender. Due to traditional roles and male rural urban migration, smallholder farmers are predominantly women who provide 75 percent of the labour for small-scale agriculture. They are however constrained in their access to land, credit, information and markets. As part of its constitutional review, the government is reviewing the laws of succession, which greatly affect gender land imbalances. It will also work to identify mechanisms to increase women's access to credit, information and input and output markets.

Food security. The government is reassessing food security policies with the intention of introducing pro-poor reforms. Issues under consideration include the liberalization of the maize and sugar markets that impose a significant tax on the poor who are net buyers of maize and sugar. Curtailing the Kenya Sugar Board to regulatory function and privatizing sugar factories are also under study. Rehabilitation and expansion of irrigation schemes will be part of the strategy.

Pyrethrum. The government is planning to liberalize the pyrethrum sector, and restrict the pyrethrum board to regulatory functions.

Coffee sector. Following reforms in the tea and dairy sectors, the government is considering similar reforms in the coffee sector with the objective of increasing the share of final sales that farmers receive. Reforms would include legislative amendments to the Coffee Act to allow growers to sell coffee outside the auction, and the establishment of an agency to operate processing, marketing and inputs distribution. Improvement in cooperative governance among the coffee marketing societies is expected to raise the proportion of end market value received by members and thus boost the members' morale to increase coffee output.

Cotton and rice sectors. The government plans to support plans for rehabilitation and development of irrigation systems to support the revitalization of cotton and rice sectors.

Livestock sector. This sector has a high growth potential and is of priority importance for subsistence farmers and pastoralists. The government plans to implement a concerted strategy for disease outbreak prevention and control, and improving quality and certification of veterinarians and other service providers. It is also considering the introduction of a single permit system for cattle movement, reviewing options for a decentralized and private sector provided network of slaughterhouses, expanding access to water sources, and improving security.

Fisheries Sector. Fresh water and marine fisheries have significant growth potential in improving the livelihood of communities of Western and Coastal regions of Kenya, and they are a source of foreign exchange earnings. The government is committed to developing an enabling environment to ensure sustainability in fisheries development and management. A fisheries policy and master plan is currently under development.

Public resource allocation. The government is committed to restructuring public spending in the Ministry of Agriculture to allocate a greater share of resources to priority programs. This will require significant rationalization of agricultural parastatals. 
Environment. Adequate management of environmental resources is key for long-term sustainable economic growth in rural areas. The government is in the process of implementing the National Environment Action Plan (NEAP) and Environment Management and Coordination Act (1999). As a result, the government established the National Environmental Management Authority, responsible for setting and enforcing environmental standards and which is expected to be fully operational by 2005 . The Ministry is carrying out a natural resource inventory and valuation. Other activities include the implementation of WSSD, MDG, and Lake Victoria Environmental Management Project.

Forestry. Activities in forestry include implementation of the Forestry Development Policy, enforcement of the Forestry Act, and promotion of private sector participation in afforestation and management of forest plantations.

Wildlife management. The government is working with local communities in conservation of wildlife and benefit sharing, implementing measures to manage human-wildlife conflicts, and strengthening the capacity of Kenya Wildlife Services.

Areas for further private sector involvement. Reforms are opening the doors for greater private sector participation in the areas of rural infrastructure, fisheries, mineral exploration and exploitation, slaughterhouses and livestock exports, particularly from arid and semi-arid lands (ASALs), agricultural processing and marketing, financial services, and input supply.

Overall, the government is requesting additional support from its development partners to operationalize agricultural policy in the areas outlined above, and promote environmental protection under the strong belief that careful and timely reforms can help release the major untapped potential of the sector.

\section{Poverty Targeted Programs}

To address poverty reduction targets, the ERS identified some priority programs that target poor communities, the poor in arid and semi-arid areas, the urban poor, and marginalized groups. These programs include the establishment of a social action fund, the development of arid and semi-arid areas, the implementation of slum upgrading programs, and the development of a program to reduce the vulnerability of marginalized groups.

\section{The social action fund}

The government plans to establish the Kenya Social Action Fund to support and finance the implementation of productive community-driven development projects. The fund will operate within a framework for community project development, improved planning, and transparent selection and financing. The fund is meant to foster community-driven development in an accountable and transparent manner.

\section{Arid and semi-arid lands (ASAL) program}

The ASAL program is a multi-sector program designed to cater to geographical areas with high poverty incidence that have traditionally been a low priority in public resource allocation and programs. This government has committed to reverse past inequities and promote development and poverty reduction in these areas. 
The strategy in ASAL aims at combining activities in infrastructure and productive sectors, with human resource development, security enhancement, and land tenure reforms. On the productive sectors side, the program aims at supporting infrastructure development to rehabilitate roads and mobilize community participation in feeder road maintenance; implement a broad-based livestock development policy; facilitate private sector development of fishing infrastructure; and strengthen community-based- and eco-tourism. In human resource development, the objective is to start closing the gap with the rest of the country by developing a creative schooling program for pastoralist children, strengthening community-based health care systems and preventive medicine, and improving food security through the implementation of community-based early warning systems. Additional activities include strengthening security and increasing border surveillance; and improving land tenure by undertaking data based inventories of tenure arrangements, reviewing adjudication processes, and establishing accountable land boards.

Currently the most comprehensive integrated intervention in ASAL is undertaken by the Arid Lands Resource Management Programme (ALRMP), which is a community-driven initiative to finance community projects on livestock marketing, small infrastructure, development and rehabilitation of bore holes, dams and water pans, animal disease control, development of roads and stock routes, and promotion of bee-keeping. The government plans to expand this program to all ASAL districts.

\section{Slum upgrading and low-cost housing}

The objective of the slum upgrading program is to improve the living conditions of millions of urban poor that live in urban slums mainly in Nairobi and Mombasa and lack access to basic water and sanitation, road, energy and housing infrastructure. The program will develop slum upgrading and relocation plans that will include land adjudication and registration, expansion of water network and sanitation facilities, provision of electricity distribution points, upgrading of slum roads, and enactment of housing legislation to facilitate private sector expansion of low cost housing and housing financing.

In housing, the government is targeting construction of 150,000 housing units annually through its slum upgrading program, completion of stalled housing projects, adoption of innovative cost effective building materials and technologies, provision of new tenant purchase housing schemes, and promotion of full scale development of secondary mortgage market. The government seeks private sector participation for construction of low cost housing in selected urban centres under concessionary terms.

\section{Vulnerability}

The vulnerability program will be designed to target marginalized and vulnerable groups and begin closing the gap in their access to public services. Particular attention will be focused on orphans, the youth, women and the disabled. The government seeks the support of development partners in the development of these programs. 


\section{Chapter 5: Governance}

Poor economic governance, including high levels of corruption and poor management of public resources, is one of the key impediments to economic and social development. It undermines development by distorting the rule of law and weakening the institutional foundation on which economic growth depends. The harmful effects of weak governance are especially severe on the poor, who are most reliant on the provision of public services, and are least capable of paying the extra costs associated with bribery, fraud, and the misappropriation of economic resources. Corruption, a major manifestation of poor governance, and poverty are linked through many indirect channels. At a macro level, corruption hampers a country's ability to attract investment, the effectiveness of its institutions and revenue generating capacity. Corruption affects the way public money is allocated, diverting expenditures away from sectors such as health and education to sectors such as public works where contracts can be manipulated and bribes more easily secured.

The government is committed to eliminating corruption, restoring the rule of law and bringing about equitable development that favours all citizens. Securing lasting improvements in governance represents a major challenge that will require focused and sustained effort to build stronger institutions that are able to effectively apply the law and to manage public resources with integrity. The government has already taken important steps. It created a new department of governance and ethics in the Office of the President, and the Ministry of Justice and Constitutional Affairs with strong leadership to co-ordinate reforms across the various institutions in this highly interconnected sector. A process of review and harmonisation's of Kenyan laws has also started under the reconstituted Law Reform Commission, in charge of updating several important acts, including the company and investment laws intended to improve the investment climate. This chapter presents key government programs and initiatives in these areas.

\section{Public Safety, Law and Order}

Contributing to weak public safety, law and order are the poor terms and conditions of service for police and other security personnel, weak legal and justice regimes, increasing sophistication of criminals, proliferation of firearms and light weapons, strengthening networks of international terrorist organisations, insecurity in neighbouring countries, weakening of traditional conflict resolution mechanisms, and rising drug trafficking and substances abuse. A lack of prison capacity and lack of ineffective co-ordination between the police, judiciary, and other institutions of public security make the problem worse.

The broad sector objectives are to restore rule of law, to maintain an efficient and motivated police force, to promote good governance by developing a strong co-ordinated administration and governance system; to eliminate corruption; to strengthen capacity for crime management, investigation and prosecution; and to strengthen capacity and co-ordination of institutions within the sector. Other objectives are to increase the efficiency and lower the costs of the judiciary, especially for the poor; to strengthen the legal and justice institutions; to create an enabling legal and regulatory framework; and to reduce overcrowding of prisons.

Outcome targets are (a) to increase the ratio of convictions from 21 percent of reported criminal cases in 1999 to 60 percent in 2006, and (b) to reduce the number of reported crimes from 63,000 in 2001 to 35,000 in 2006. 
Priorities include improving training of police officers, recruiting new police officers, equipping the police with modern equipment and technology; improving living conditions of police officers; rehabilitating 20 courts; and strengthening the specialised police units. Other activities include establishing a taskforce outside the Civil Service Reform Commission; operationalizing the Human Rights Commission; completing investigations into the Goldenberg scandal; establishing the office of the Ombudsman; developing and operationalizing a 5-year strategic master plan to fight corruption; and implementing a framework for cross-border policing and collaboration.

\section{Police reforms}

The police force plays a major role in promoting public safety, law, and order. However, unsatisfactory enforcement of the rule of law and low standards of professionalism and competence within the police force has worsened the security situation in the country.

The government is addressing the problem by preparing a full diagnosis of the police and budgetary allocations within the sector ensuing recommendations will be incorporated in the design of a comprehensive strategy to professionalize the police force, reform the structure of incentives police forces face, increase their linkages and accountability to the community. Professionalism in the police will require the implementation of a training and re-equipment program to enhance efficiency and effectiveness in handling crimes. Due to wage bill constraints, the restructuring of incentives in the short term will focus on improving the living conditions of police officers including through provision of decent accommodation.

By January 2004, the police force salaries were increased which is expected to improve their morale and boost their productivity. To strengthen the linkage with the community, the program will promote redeployment of police, initiation of the community policing aimed at friendly working relations with the public, establishment of monitorable outcome indicators, and strengthening of partnerships between the police force and the private sector security agencies. The police Department is implementing a Rapid Result Initiative of one hundred days with an objective of enhancing security in the Central Business District. The launching was done on $23^{\text {rd }}$ January 2004 and has been very successful. The members of the private sector organisation have expressed the willingness to support the initiative as a collaborative effort with the Government. The outcome will be replicated to the other major urban centres and throughout the country. The recruitment of the police to effectively undertake these initiative will be carried out in the medium term. The recruitment will enable the effectiveness and efficiency in the security forces and further establishment and strengthening of anti-banditry units, a tourism police unit, antiterrorism police units, port patrol units, and community policing initiatives and anti-corruption units. The reform will be complemented by the development of a framework to undertake comprehensive intelligence research in crime and security; and a revision and enactment of laws to deal with modern crime challenges such as terrorism, fraud, money laundering, e-commerce crimes, and tax evasion.

\section{Anti-corruption measures}

Pervasive corruption has slowed growth and deepened the poverty levels in the country. Eliminating corruption will free significant resources for investment in infrastructure and in programs that deliver services to the poor. 
To eliminate corruption the government enacted and is implementing the Economic Crimes Act (2003). This provides for the establishment of an Anti-Corruption Commission, which the government intends to make fully operational by early 2004 . The commission mandate is to achieve a zero tolerance on corruption, enhance accountability and transparency in the conduct of the national affairs focusing on internationally accepted standards. It also held a national conference on corruption and announced the preparation of a five-year anti-corruption strategy.

The action plan to support the strategy is currently under preparation and will include regular surveys and monitorable indicators to measure progress made in curbing corruption. To reduce corruption in the public service, parliament approved the Public Officers Ethics Act in 2003, which requires all public officials (including the President), employees and their families to declare their assets. This provision was implemented in October 2003. Finally, the government is strengthening the capacity of the Kenya Anti Corruption Commission.

These policies are reflected by concrete actions, such as: i) investigation of the Goldenberg scandal, ii) replacement of corrupt judges, iii) repossessing of grabbed land and public housing, and iv) banning of corrupt contractors from participating in public procurement.

Other measures are intended to reduce opportunities for corruption and eliminating conflicts of interest. These include the transfer of the responsibility for the regulation of the financial sector from the Ministry of Finance to the Central Bank of Kenya; the cancellation of all stalled projects; the elimination of pending bills; the timely presentation of final accounts on government operations by the Controller and Auditor General; and the reform of the public sector procurement system.

The programme outcome is to reduce corruption incidents and lower Kenya's international rating by 50 percent annually, ensure that the Publics Ethics Act is fully implemented and set up an office of ombudsman where members of public can lodge complaints and petitions.

\section{Judicial reforms and dispensation of justice}

The reliable and accessible dispensation of justice is critical for a well functioning society. Hence a sound system that is speedy, accessible, and affordable to the poor, fair, and not corrupt promotes and sustains economic development.

The government has taken several actions to improve the dispensation of justice. Of key importance is the establishment of the Ministry of Justice and Constitutional Affairs, which is responsible for policy on administration of justice, law reform, anti-corruption strategies, integrity and ethics, legal sector reform, legal aid and advisory services, and the Kenya National Human Rights Commission. The ministry's five-year strategy is to improve legal education, increase access to justice through support to legal aid, create mechanisms for community justice, zoning of courts in various parts of the country into 12 circuit courts to offer Judicial Service to areas without Courts and develop and implement a five year anti-corruption campaign. The campaign of fighting corruption has started by forming a tribunal to try judges on allegation of corruption and related cases that were identified. The ministry has also spearhead an ambitious program of law reform to take into account the provisions of the constitution that is expected to be adopted in 2003. The Ministry is expected to benefit from a proposed Justice and Integrity Project being supported by development partners.

Activities/Programmes to be undertaken involves recruitment of Magistrates/Kadhis to cope with the increased cases, training of staff to enhance efficiency, automation of court registries to 
enhance information flows, acquisition of more vehicles to facilitate accessibility to remote areas for delivery of Judicial services and court hearings in up country stations and installation of security equipment in Courts.

In addition, the government will take steps to reduce overcrowding of jails and prisons. These steps will address prison capacity, institutional coordination between the judiciary and the office of the Attorney General, prisons, the police, and the children and probation department, inspection and enforcement of rules and regulations. It will also sentence more non-violent offenders convicted of petty crimes to community service, implementing the community service order act.

\section{Improving immigration services}

Immigration services control the entry and exit of persons seeking to live temporarily or permanently in the country. Despite the critical role of immigration services, various obstacles hinder delivery of services, such as lack of collaboration among stakeholders, inadequate computerization, and lack of appropriate equipment.

The government has recruited 116 immigration officers to assist in curbing entry of illegal aliens. It is also preparing to provide visa stickers that contain a security mark that cannot be forged, rather than issuing manually stamped visas. In the future it will enhance collaboration with relevant stakeholders, computerize the institutional system and provide specialized equipment, and ensure that all immigrants are in possession of requisite passes and permits.

\section{Public Administration}

An efficient public administration ensures that public services are delivered efficiently, effectively, and for their intended purposes. The government aims to create a leaner, more efficient, motivated and productive public service. It also intends to accelerate the parastatal privatisation process.

The Government will continue with reforms in the civil service, Local Authorities and public enterprises to attract private sector investment and improve delivery of public services. Other critical components of the government's strategy include separating powers between various branches of government; strengthening the rule of law; decentralising delivery of public services; and making the conduct of public operations at all levels of government more accountable and transparent. These measures are expected to improve revenue collection; reduce rent-seeking; and increase the productivity of public investments.

Targets are to eliminate pending bills in all sectors, resolve stalled projects, and increase the project completion rate, during 2003-06. Other targets are to increase the proportion of budgetary resources controlled by local governments, and to increase the proportion of communities reporting having greater control over local development resources.

\section{Civil service reforms}

The government will accelerate the public service reform programme to focus public financial and human resources on the delivery of core government functions, and to reduce the share of 
the wage bill in the GDP to 8.5 percent of GDP by $2005 / 06$. Reforms have previously included rationalization of ministerial functions, structures, and staffing.

The civil service reform will in the medium term focus on improving performance by: (a) rightsizing the civil service, (b) reforming pay structures, (c) reforming pensions, and (d) building capacity of the public administration. Most of the resources will be spent on rightsizing the civil service. As part of the measures aimed at reducing the relative size of the wage bill in total expenditure, a study is being undertaken to recommend modalities for reducing the wage bill.

\section{Public expenditure systems}

The government places considerable importance on the effective control and close monitoring of public expenditure as a means of reducing corruption, minimizing deviations of budget outcomes from intentions, promoting budget discipline, and preventing the accumulation of new arrears. For detailed actions in this area, see public expenditure reform in chapter 2.

\section{Parastatal reform}

The government set up a high level committee, chaired by the head of the public service, to review the performance and viability of state corporations. One hundred thirty six (136) state corporations and statutory boards are covered in the analysis. The recommendations of the committee, including possible restructuring, mergers and legislative reforms, have been discussed by the cabinet Economic sub-committee and are waiting finalization and submission to cabinet for approval.

\section{Local government reforms}

As part of the Constitutional review process, local government reforms will be implemented to improve delivery of services and accelerate the devolution of decision-making authority to the local levels.

Currently, local finances are being improved through the local authority transfer fund (LATF). Local business licensing has also been rationalized and other measures have been introduced to improve local level financial management, revenue mobilization and service delivery linked to the LATF system. The government with the support from development partners is also supporting capacity building in local authorities and a comprehensive training programme and master plan for training of local authority personnel is being developed.

During the recovery period, local government reforms will be strengthened. Actions include strengthening of monitoring and evaluation systems to cover programs implemented by local governments. Reforms also include further Operationalizing the Kenya Local Government Reform Programme (KLGRP) by implementing the local authority service delivery action plan and establishing an integrated financial management information system; developing and implementing a comprehensive decentralization strategy; and reviewing the Local Authority Act. These reforms are aimed empowering local authorities, and reducing conflicts between the central government and local authorities. 


\section{Chapter 6: Financing Framework}

\section{Introduction}

The Interim Investment Programme of the Economic Recovery Strategy had a total estimated cost of Kshs. 706.92 billion compared to committed funding (in the Printed Estimates of the 2003/04 budget) of Kshs. 154 billion, including Kshs. 47 billion of donor funds. This therefore left a substantial financing deficit to be met from increased external borrowing, public expenditure restructuring and private sector investment. The investment programme estimated that Kshs. 96.9 billion would be raised from private sector participation, Kshs. 171 from additional external borrowing (bringing the total external resources to Kshs. 219 billion or US\$ 2.9 billion at prevailing exchange rates) while Kshs. 119.4 billion was to be raised from expenditure restructuring. To ensure that the funding was adequate to implement the existing projects, a prioritization schedule was provided in the strategy, with activities not provided for going into a pipeline to be reviewed should funding allow.

Since the launch of the investment programme, several important changes have taken place including:

- $\quad$ The successful holding of a Consultative Group (CG) meeting, where a total of US\$ 4.1 billion was pledged: this sets an upper limit on the level of external resources available for funding the programme;

- The country entering into a Poverty Reduction and Growth Facility (PRGF) arrangement with the IMF with implications for the macro economic framework;

- The completion of an exercise on prioritization which has enabled the sectors to be more focused in their expenditure requirements.

The changed environment has enabled a complete review of the ERS investment programme and thus its financing framework.

\section{COSTS OF IMPLEMENTING THE REVISED INVESTMENT PROGRAMME}

Table 6.1 below provides an estimate of the cost of implementing the projects and programmes enumerated in the sectoral chapters.

Table 6.1: Costs of Implementing the Economic Recovery Strategy (values in Kshs. mn)

\begin{tabular}{|l|c|c|}
\hline Sector & Implementation Cost (Kshs.Mn) & $\begin{array}{c}\text { percent of Total } \\
\text { Costs }\end{array}$ \\
\hline Macro Economic Sector & $8,599.4$ & 2.51 \\
\hline Public Administration & $7,914.5$ & 2.31 \\
\hline Public Safety Law and Order & 43,890 & 12.83 \\
\hline Agriculture and Rural Development & $38,488.5$ & 11.25 \\
\hline Tourism Trade and Industry & $16,254.8$ & 4.75 \\
\hline Human Resource Development & 143,400 & 41.92 \\
\hline Physical Infrastructure & 81,018 & 23.68 \\
\hline Information Technology & 2,500 & 0.73 \\
\hline Total & $\mathbf{3 4 2 , 0 6 2 . 2}$ & $\mathbf{1 0 0 . 0}$ \\
\hline
\end{tabular}


From the table above, the human resource and infrastructure sectors are expected to account for the bulk of expenditure, 66percent while the public administration sector accounts for only 2.31percent.

Table 6.2 below provides a breakdown of currently forecast expenditures under the base case scenario. The table shows that total Government expenditures are expected to total Kshs. 1,326 billion over 2003/04-2006/07. Of this, Kshs. 422.4 billion are expected to be personnel emoluments, Kshs. 116.3 billion for interest payments, and Kshs. 69.7 billion for pensions. An expected Kshs. 369.3 billion is available for ERS expenditures, of which Kshs. 280 billion will be development expenditures, Kshs. 36 billion for the free education programme and Kshs. 26.2 billion for non-wage health services.

\section{Table 6.2: Projected Expenditures}

\begin{tabular}{|c|c|c|c|c|c|c|}
\hline EXPENDITURE CATEGORY & $\begin{array}{c}2002 / 03 \\
\text { Actual }\end{array}$ & $\begin{array}{c}2003 / 04 \\
\text { Estimates }\end{array}$ & $\begin{array}{c}2004 / 05 \\
\text { Proposed } \\
\end{array}$ & $\begin{array}{c}2005 / 06 \\
\text { Proposed } \\
\end{array}$ & $\begin{array}{c}2006 / 07 \\
\text { Proposed } \\
\end{array}$ & $\begin{array}{c}\text { TOTAL } \\
2003 / 04- \\
2006 / 07 \\
\end{array}$ \\
\hline \multicolumn{7}{|l|}{ Current } \\
\hline Salaries and Allowances & 85,087 & 96,716 & 101,583 & 108,514 & 115,585 & 422,397 \\
\hline Ministerial expend.(Excl. Free educ\& health.) & 29,897 & 35,336 & 35,202 & 32,484 & 32,800 & 135,822 \\
\hline \multicolumn{7}{|l|}{ Transfer Payments } \\
\hline Transfers to local Government & 3,708 & 3,656 & 3,543 & 3,974 & 4,187 & 15,360 \\
\hline \multicolumn{7}{|l|}{ Transfers to households } \\
\hline Pensions & 12,220 & 14,067 & 16,099 & 18,434 & 21,118 & 69,717 \\
\hline Civil Service Reforms & 957 & 0 & 5,335 & 0 & 0 & 5,335 \\
\hline Transfers to non profit institutions & 40,189 & 45,749 & 46,315 & 46,534 & 47,806 & 186,404 \\
\hline Parastatals (Excl. in $\mathrm{MOH}$ ) & 7,630 & 8,840 & 9,130 & 9,767 & 10,362 & 38,099 \\
\hline Parastatals in $\mathrm{MOH}$ & 3,933 & 4,430 & 4,621 & 4,803 & 4,992 & 18,846 \\
\hline Universities & 6,795 & 7,470 & 7,566 & 7,865 & 8,174 & 31,075 \\
\hline Others & 21,831 & 25,009 & 24,998 & 24,099 & 24,278 & 98,384 \\
\hline Interest Payments & 35,226 & 33,742 & 27,081 & 27,476 & 28,010 & 116,309 \\
\hline Capital Transfers & 1,582 & 2,897 & 835 & 1,103 & 1,072 & 5,907 \\
\hline Total Identified Components & 208,867 & 232,163 & 235,993 & 238,519 & 250,576 & $1,143,655$ \\
\hline Total Projected Government Expenditures & 256,115 & 297,194 & 324,726 & 336,131 & 368,529 & $1,326,580$ \\
\hline Expenditure in USD millions & 3,313 & 3,923 & 4,270 & 4,371 & 4,755 & 17,319 \\
\hline Implied Other Expenditures & 47,248 & 65,031 & 88,733 & 97,612 & 117,953 & 369,329 \\
\hline of which Development Expenditure & 39,630 & 46,549 & 64,054 & 76,688 & 92,715 & 280,007 \\
\hline of which GOK for free education & 2,850 & 9,000 & 9,000 & 9,000 & 9,000 & 36,000 \\
\hline of which Recurrent Non-Wage Health & 2,916 & 3,481 & 5,175 & 7,138 & 9,390 & 25,185 \\
\hline
\end{tabular}




\section{Chapter 7: Monitoring \& Evaluation and National Statistics}

A key area of the government policy to improve governance is the development of an integrated system for monitoring and evaluating the Economic Recovery Strategy for Wealth and Employment creation.

The objective of the integrated monitoring and evaluation system is to provide the government with reliable mechanisms to measure the efficiency of government programs and the effectiveness of public policy in achieving its objectives. With appropriate links to the budget and the medium-term expenditure framework, the system will provide the government with the needed policy implementation feedback to efficiently reallocate its resources overtime. It will also set the basis for a transparent process by which the government and the international donor community can undertake a shared appraisal of results and ensure smooth release of external support including budgetary support.

\section{Integrated M\&E System}

The integrated M\&E system for the ERS will assemble and use available data and information to inform public policy. Specifically, it will track progress of the key indicators identified in the ERS logframe matrix, and provide feedback to policy-makers for improving public policy and use of public resources.

The system will monitor indicators that measure government efficiency in utilising the available resources and achievements made in the reduction of poverty. These indicators will include:

- Input and process indicators, such as budget execution and adoption of reforms, across programs and governmental institutions to ascertain progress in the implementation of policies and programs;

- Output indicators, such as goods and services provided by the public sector, to measure the efficiency in the utilization of government resources, and indicators that ascertain the effectiveness of public policy in achieving its developmental objectives; and.

- Outcome and impact indicators, that inform on the actual achievements made on the Country's economic recovery and reduction of poverty will form the basis for the evaluation of the ERS policies and programs.

In the latter case, it is recognized that changes in developmental outcomes and impacts may be affected by external factors that may not be under the control of the government, such as weather conditions, world economy, conflict, etc. For this reason, attributing change to particular policies is often difficult. To address this issue, the government plans to (i) develop a national research agenda in consultation and collaboration with the academic and donor communities. This agenda will include impact evaluation studies that will analyze the effectiveness of key government policies and programs in reaching desired objectives in greater depth; and (ii) the strengthening the Poverty Analysis and Research Unit (PARU) of the CBS with a view to increasing its capacity in undertaking outcome and impact oriented evaluation and other related studies.

Finally, but most importantly, the Monitoring and Evaluation System will provide feedback mechanisms to policy-making, budget and medium-term expenditure framework to ensure that the lessons learnt by monitoring and evaluating government programs and policies are used to improve the effectiveness of such programs and policies. While the inputs and outputs will be 
monitored and reported on quarterly basis, the outcome and impact indicators will be reported at intervals ranging from one year to five years.

\section{Logframe Matrix and Priority Indicators}

The government has developed a monitorable result-based logical framework matrix, which is consistent with the strategies and priorities of the ERS and PRSP. The matrix spells out a consistent framework for ERS implementation, identifies key indicators and targets, and identifies major constraints and risks (see Annex I). It provides a solid foundation for the development of a well-focused monitoring and evaluation system. However, not all the input, output, outcome and impact indicators as listed in the matrix can be effectively monitored and evaluated. In the short term, only manageable number of priority indicators that focus on the MDG indictors will be made mandatory for monitoring and evaluation at all levels of the M\&E framework. The indicators that will be identified through a process of stakeholder consultations will form the basis for an M\&E baseline data that will regularly be collected through household surveys, establishment based surveys and/or administrative records.

\section{Statistics strategic plan}

The government, through Parliament endorsed a Strategic Plan for Statistics and gathered donor support for its implementation. The Plan, which is being reviewed to transform it into a STATCAP Master Plan, will ensure that the data required for poverty assessments and public policy evaluation are produced and disseminated regularly and in a timely manner. The Plan will introduce a paradigm shift towards integrated surveys with diverse objectives geared towards addressing ERS and PRSP objectives, as well as the MDGs. The Central Bureau of Statistics will be responsible for improving the quality of data collection and analysis of data, building capacity, and dissemination.

\section{Institutional framework}

The Government in consultation with stakeholders has developed a system-wide institutional framework for monitoring and evaluating the ERS. The framework is an all-inclusive system that allows maximum participation of the community, civil society, and all development partners at all levels. Within the evolved framework, three institutions namely, the NESC, Monitoring and Evaluation Unit and National Stakeholders Forum will play a pivotal role in spearheading the implementation of the M\&E system for tracking the ERS. The National Economic and Social Council will provide oversight in the implementation of the ERS and policy advice to Cabinet and Ministries of Finance and Planning on national economic and social issues. The council will also be responsible for liasing with the private sector and civil society organisations, and agreeing on modalities for public information access and dissemination, and feedback mechanisms.

To ensure that M\&E activities are well coordinated, the government has transformed the Poverty Eradication Unit (PEU) into a Monitoring and Evaluation Unit (MEU) with the specific role of coordinating M\&E for ERS activities, store and disseminate M\&E information and data. The MEU will have a wide range of responsibilities. These include:

i. Lead the design and implementation of the government-wide M\&E action plan. The Unit will take a very active role in spurring the adoption of M\&E across the government, ensure M\&E standards, and support M\&E needs assessments and capacity building activities.

ii. Head the annual ERS review, coordinating the preparation of sector reviews, and drafting the overall annual progress report. 
iii. Coordinate the national research agenda, policy analysis and dissemination of research results to policymakers.

iv. Develop protocols for horizontal (sector to sector) sharing of knowledge and transfer of data within the government, and

v. Liaise with other organizations (academic, international and nongovernmental) to strengthen the ability of the government to leverage outside resources.

The responsibilities of MEU will highly be complemented by those of CBS. In addition to its current responsibilities, the Central Bureau of Statistics will be responsible for managing the integrated data management system, and for making available the information in a timely manner to the MEU who will in turn make it available to National Economic and Social Council, and other users.

The Forum that brings together the sector working and the thematic groups, civil society and private sector organisations will ensure ownership and legitimisation of the M\&E for ERS processes. A twelve member M\&E Steering Committee will serve as a technical arm to the Forum and its main responsibilities will be to provide a link between policy decision makers with the technical working groups on M\&E.

At the devolved level, similar structures will be put in place. A District Stakeholders Forum that incorporates existing government structures with communities and civil society organisations in the monitoring and evaluation of poverty reduction programs at the district and community level. The District Stakeholders Forum will provide strategic direction on M\&E at the district level. The District Planning Units will be strengthened to coordinate M\&E activities at local level. It will collect, collate, analyse, store and disseminate $\mathrm{M} \& \mathrm{E}$ data and information. At the community level, efforts will be made to develop structures for facilitating participatory monitoring and evaluation of poverty programs. This is aimed at ensuring that even the targeted poor themselves track and give feedback on the ERS policy and programs implementation.

Institutionalizing monitoring and evaluation as a management tool across different levels and sectors of government will require not only an operating institutional framework, but also capacity building of the implementers. Training and technology for national and local governments is critical and the government plans sensitise and train staff of key Ministries and public institutions on the value of $\mathrm{M} \& \mathrm{E}$ for program management, institutional efficiency, and policy effectiveness, and install needed equipment.

\section{Integrated data management system}

The government plans to establish an integrated data management system to facilitate timely and opportune delivery of information to MEU, the unit responsible for tracking progress in the implementation of the ERS. The system will afford the government with vertical and horizontal monitoring capacity, strengthen its ability to identify problem areas and low performers, and improve its capability to affect success.

The system will include administrative information from all key sectors (finance, education, health, agriculture, infrastructure, etc), and information derived from the analysis of survey and census data.

Administrative data will be assembled from the Ministries' own management information systems. CBS will establish protocols for the sectors to transfer information to the integrated data management system. In each case, sector management information systems will need to be 
evaluated for quality and content. Sector-specific needs assessments and capacity-building plans will be implemented as required to ensure that relevant and good quality information is collected.

Although produced less frequently, survey and census data are more reliable than administrative data and will provide a good check on the quality of administrative data and suggest ways to improve them over time. Specifically, survey data may help the government identify patterns of inaccuracies in the administrative data and repair malfunctioning administrative reporting. Mainly, survey data will be used for household level data analysis and for impact evaluation analysis of government programs and policies. The CBS is planning to undertake an integrated household budget survey (KIHBS), which is a modular survey able to provide good socioeconomic benchmarks, and has a CWIQ incorporated for subsequent M\&E activities. The KIHBS will provide critical data for estimating poverty head counts, distribution, causes, and trends. It also intends to complete a census of establishments, an international comparison of prices survey, a tourism expenditure survey, and a foreign investment survey. Finally, it plans to compile a governance statistics database.

Data from the integrated household budget survey, the living standards measurement survey, and the census of establishments will be used for household level data analysis and for impact evaluation analysis of government programs and policies. Other sources of data, such as participatory poverty assessments and client satisfaction surveys, will be invaluable for obtaining feedback on the quality and availability of public services. The foreign investment survey, the tourism expenditure survey, and the international comparison of prices survey will be used to assess trends in environment for investment and trade. Compilation of the governance database will provide baseline data for monitoring changes in perceptions of corruption.

\section{National research agenda}

The government will develop a medium-term research agenda in consultation with interested partners and with the support of the Kenyan academic community. The research agenda will put forth the priorities of the government for policy analysis and evaluation. It will also spell out programmatic areas that are critical to the achievement of the government targets specified in the logical framework matrix of the ERS.

While the Ministry of Planning and National Development has long collaborated with local research institutes and gained from their knowledge and technical capacity, the government also recognizes that evaluating the policies of the ERS may take a significant amount of resources and excellent technical skills. For this reason, the government will establish a medium-term schedule for the implementation of its research agenda following the medium-term ordering of ERS priorities.

Some of the resources will come from the government participation in the regional Poverty Analysis and Data Initiative (PADI), which supports research activities in key policy areas of regional interest.

\section{Performance-based decision making}

For monitoring and evaluation to be effective as a learning tool, the incentives structures for civil servants (salary and advancement) and for public institutions (budgetary allocations) must be designed to reward performance. For this reason, $\mathrm{M} \& \mathrm{E}$ activities will be closely linked to the ongoing civil service and program- and result-based budget reforms. The government will work to develop a consistent framework linking budget, MTEF and M\&E. 


\section{Participatory monitoring, dissemination and feedback}

One of the key elements of participatory monitoring is the availability of information. To enhance transparency and accountability, therefore, the government plans during 2003/04 to develop and implement a public information access policy. The policy will classify information gathered by the government as public or confidential, and establish the mechanisms through which public information is made available. The open access policy will be coupled with an aggressive dissemination strategy to enable communities and other developmental actors to hold service deliverers accountable for quality and quantity of their services.

The government will partner with the private sector and non-governmental organizations and agree on modalities for a shared strategy for dissemination of information and community monitoring. To this end the government will agree with civil society: i) an acceptable NGO disclosure policy, ii) a common strategy for the private sector and NGO active involvement in dissemination of information to business and special interest communities, and policy feedback activities, iii) mechanisms for public information release to private sector and NGOs, and iv) standards for NGO data collection and evaluation methodologies.

\section{Conclusion}

This investment programme is a bold attempt by the Government to fulfil its obligations to Kenyans and Kenyan investors as promised in the Economic Recovery Strategy for wealth and Employment Creation. Through this programme the Government plans to mobilise all accessible and absorbable resources to trigger faster economic growth and development, to provide better social services, to improve equity in access to the national resources, and to provide more opportunities and better environment for private sector prosperity.

The Programme provides an excellent foundation for nurturing a mutually fruitful and sustainable partnership between the Government and the private sector and between the Government and development partners. The Government hopes that our dialogue with both the private sector and the development partners will be anchored on this programme in the short to medium term. 


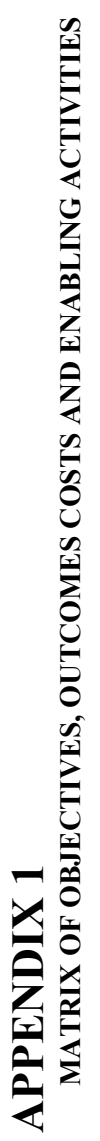




\begin{tabular}{|c|c|c|c|c|c|c|}
\hline \multirow{2}{*}{\multicolumn{7}{|c|}{ 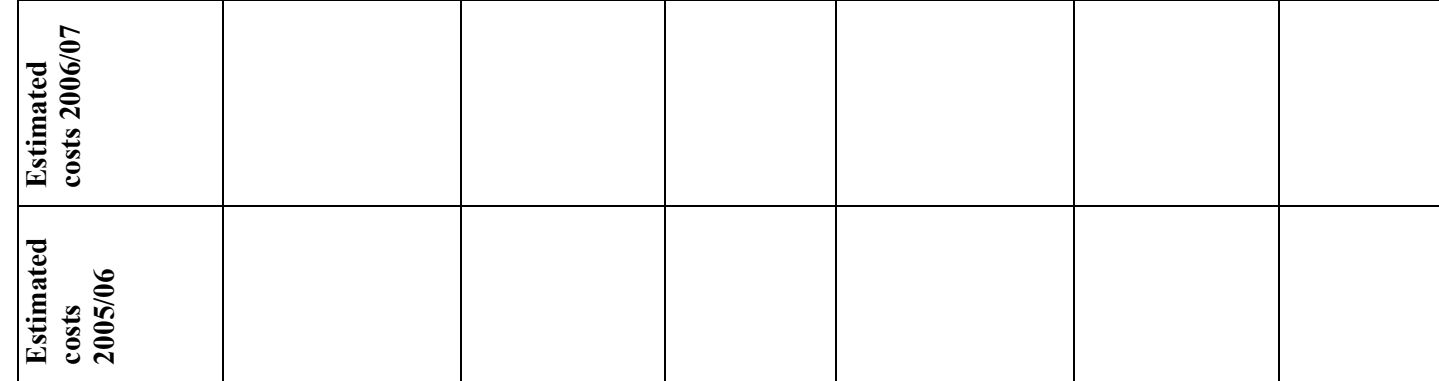 }} \\
\hline & & & & & & \\
\hline 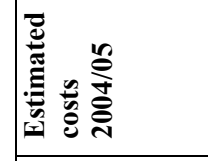 & & & & & & \\
\hline 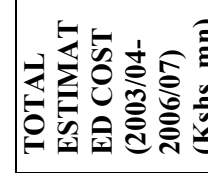 & & & $\underbrace{f}_{0}$ & & & \\
\hline 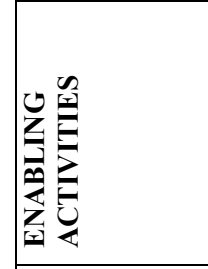 & 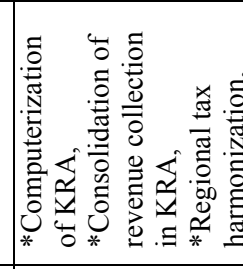 & 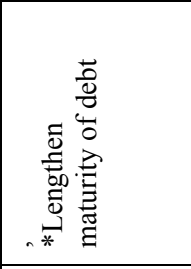 & 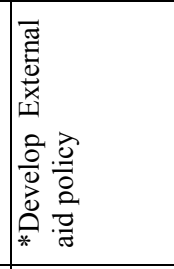 & 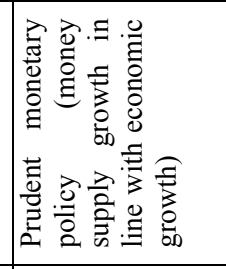 & 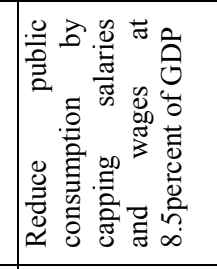 & \\
\hline 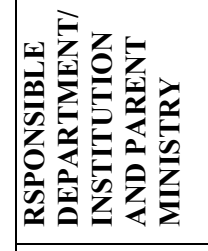 & 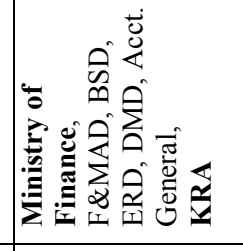 & 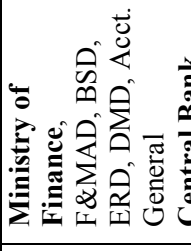 & 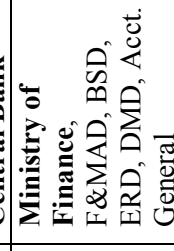 & 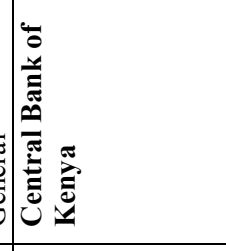 & 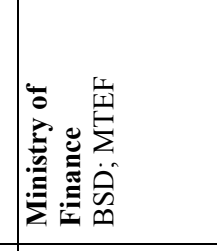 & 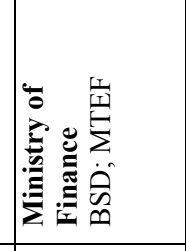 \\
\hline 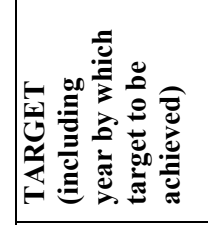 & 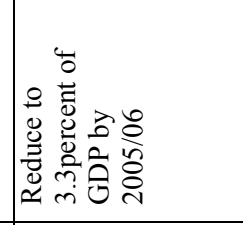 & 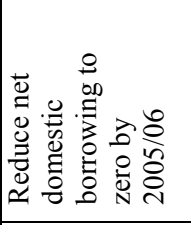 & 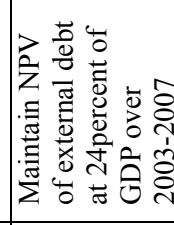 & 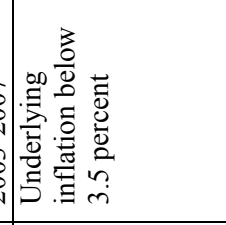 & 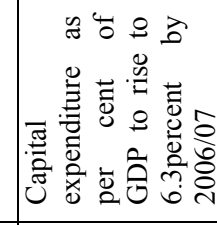 & 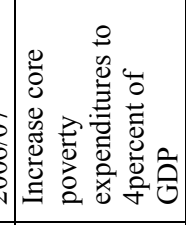 \\
\hline 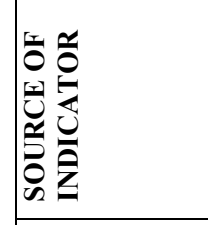 & 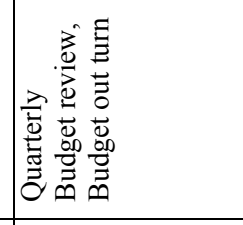 & 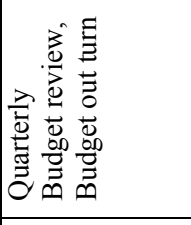 & 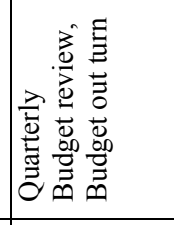 & 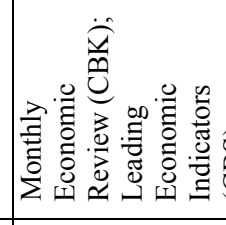 & 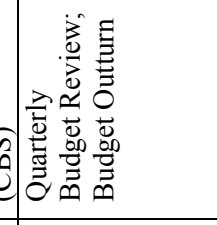 & 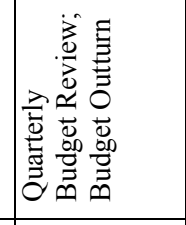 \\
\hline 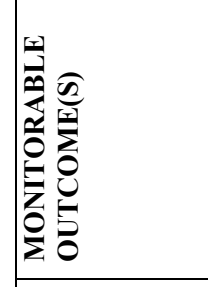 & 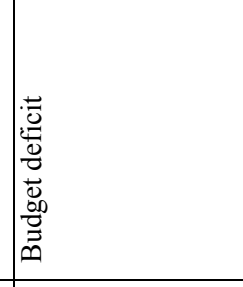 & 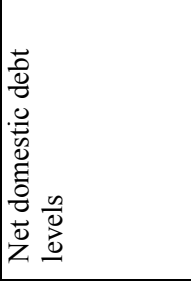 & 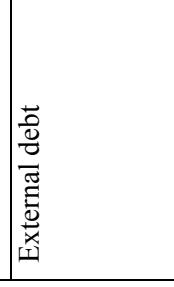 & 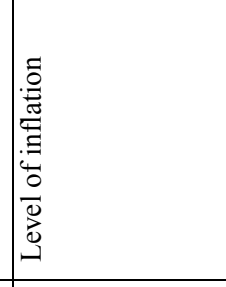 & 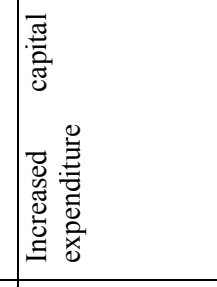 & 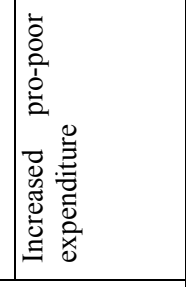 \\
\hline 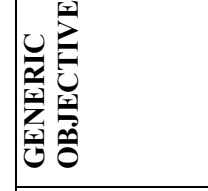 & 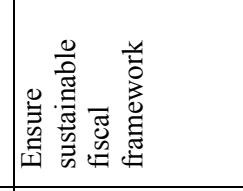 & & & 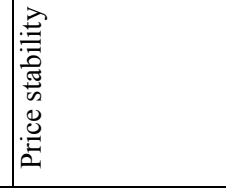 & 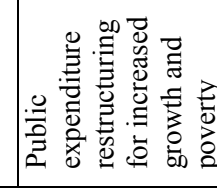 & \\
\hline $\mid$ & 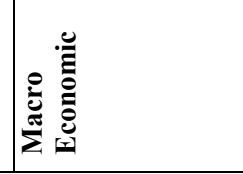 & & & & & \\
\hline
\end{tabular}

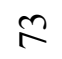




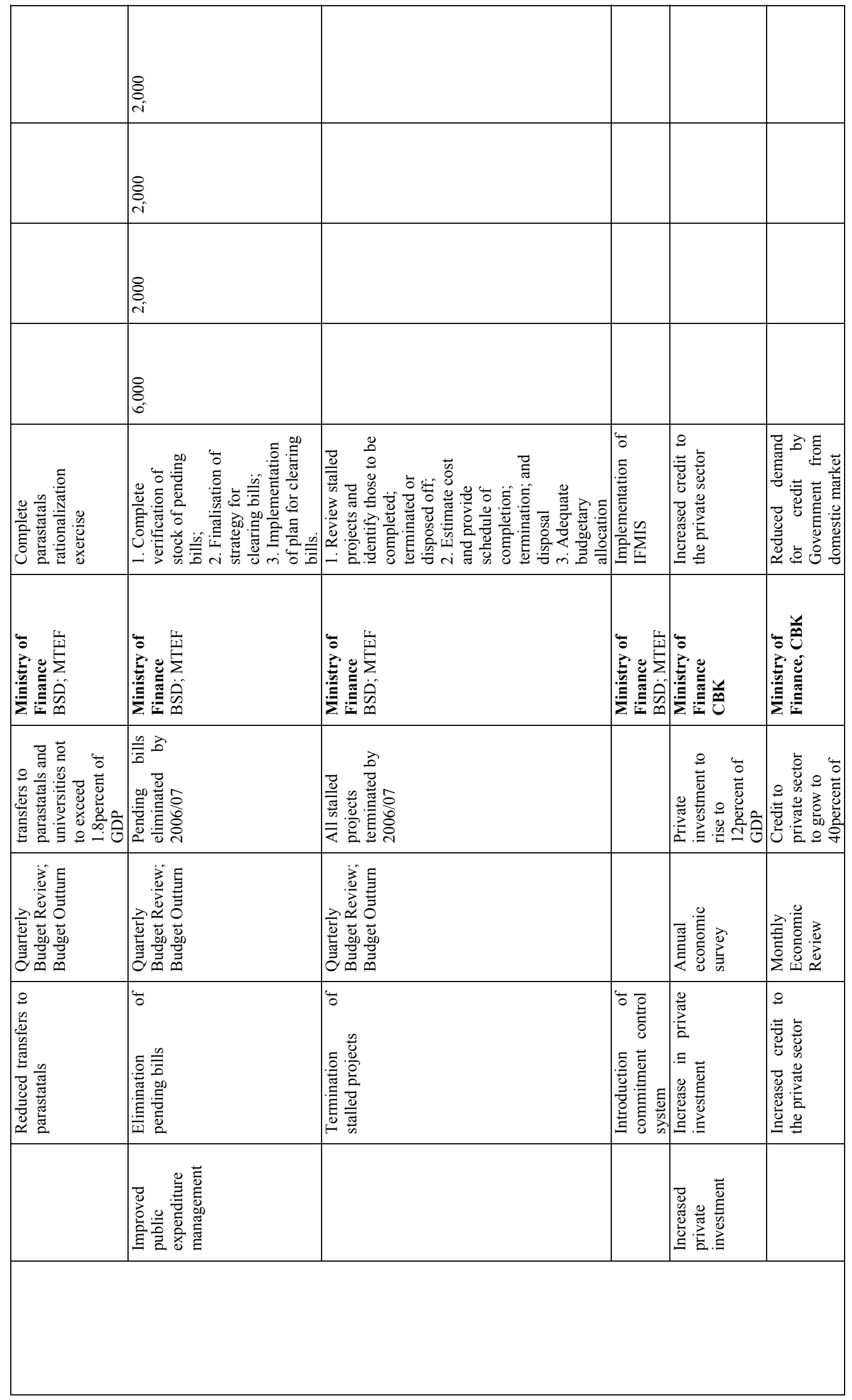




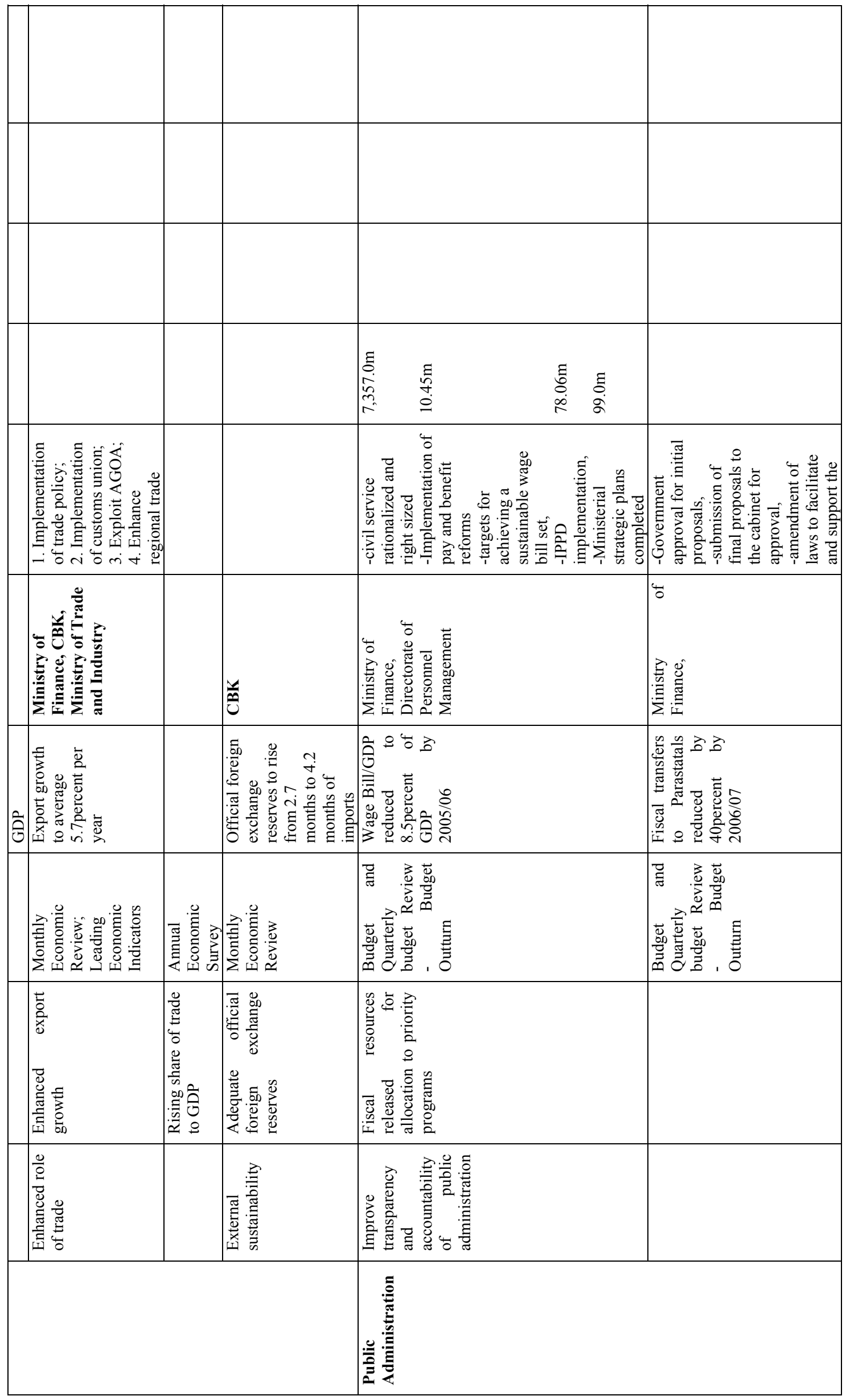




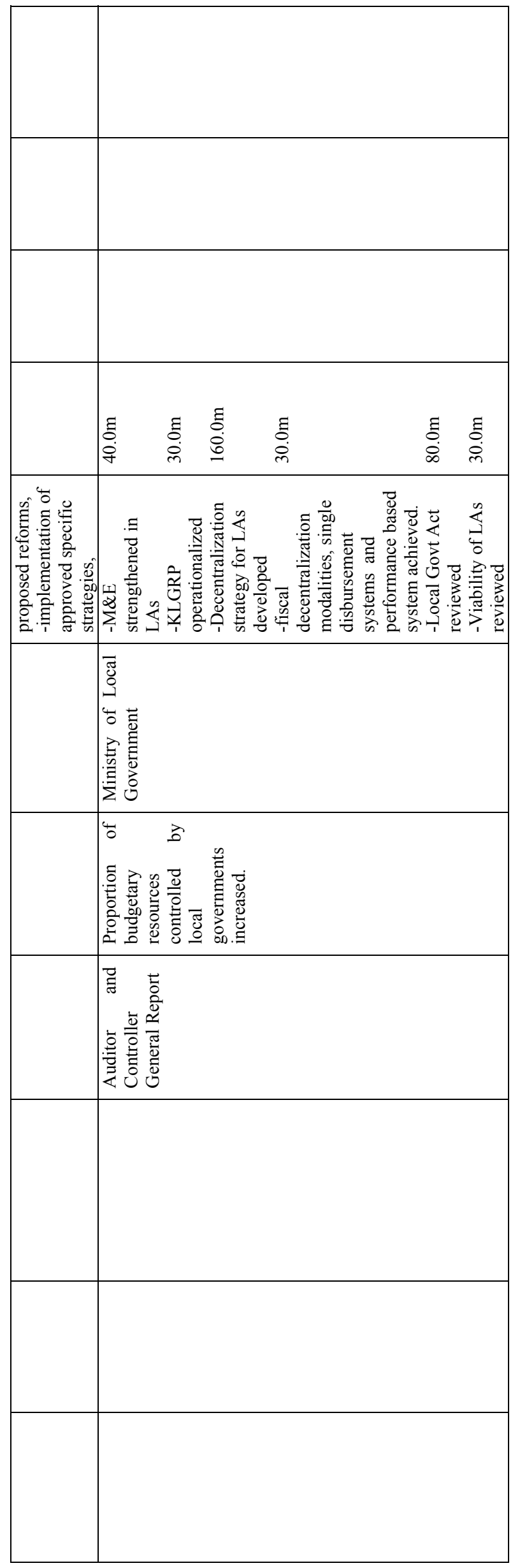

1 


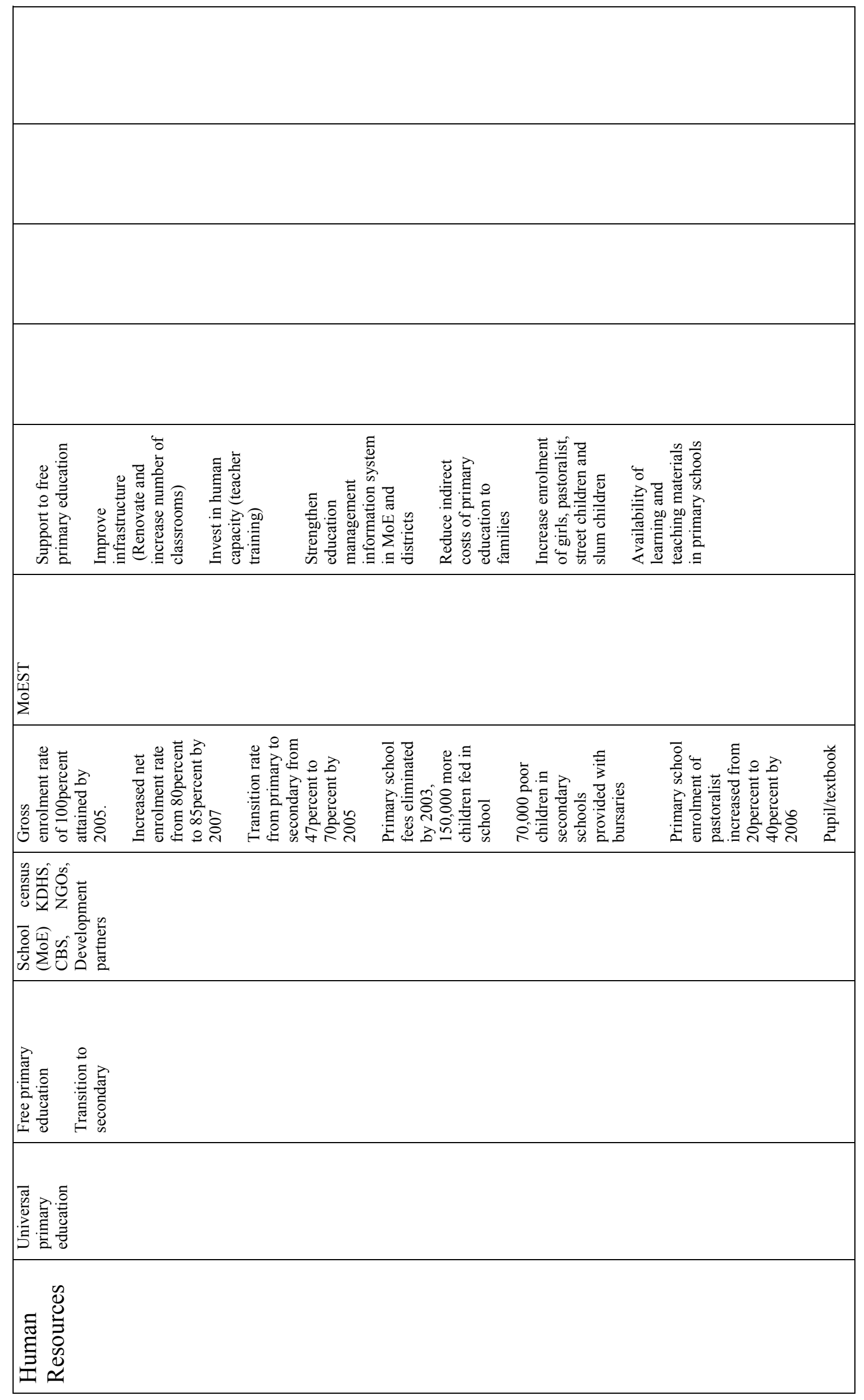

N 


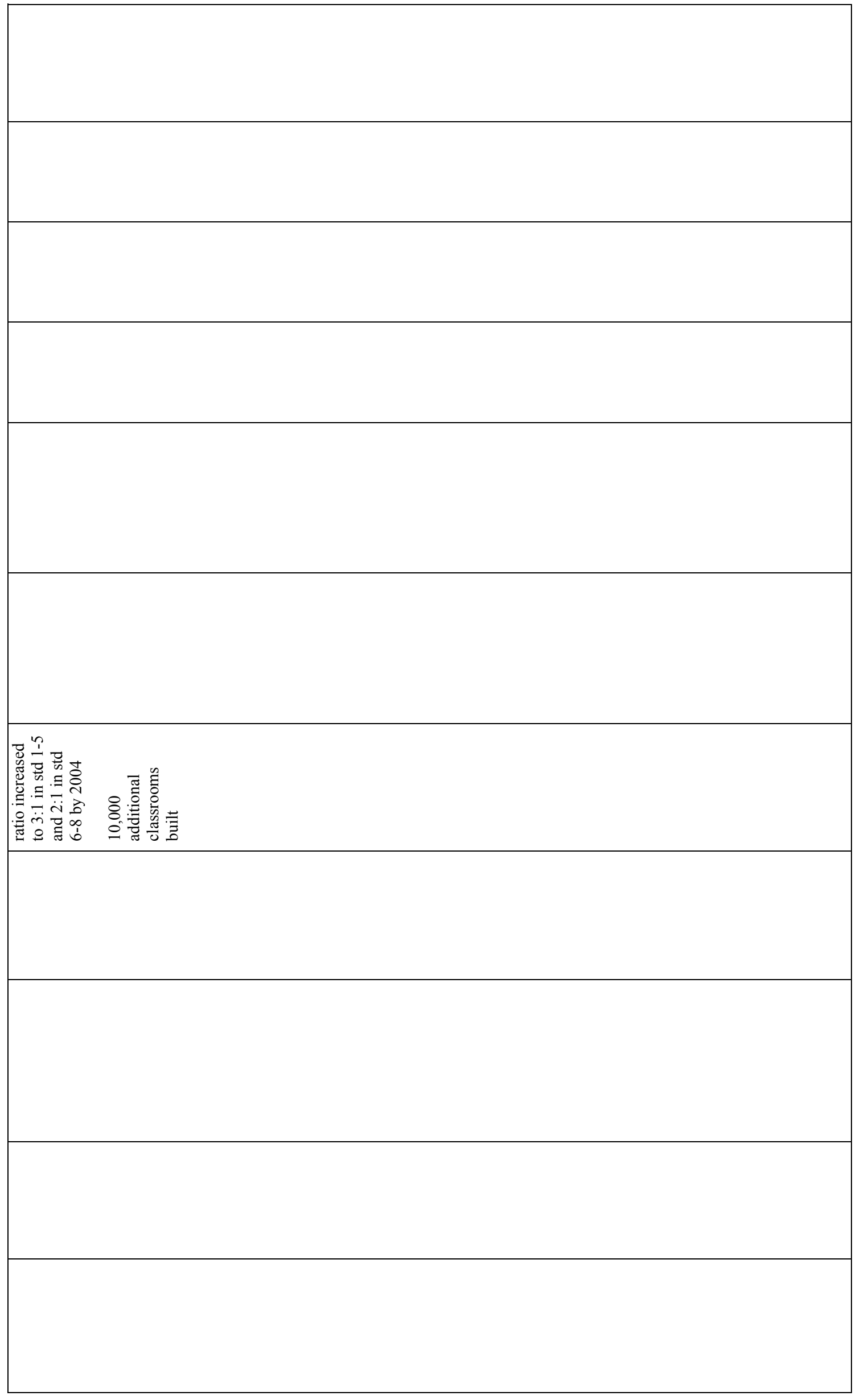




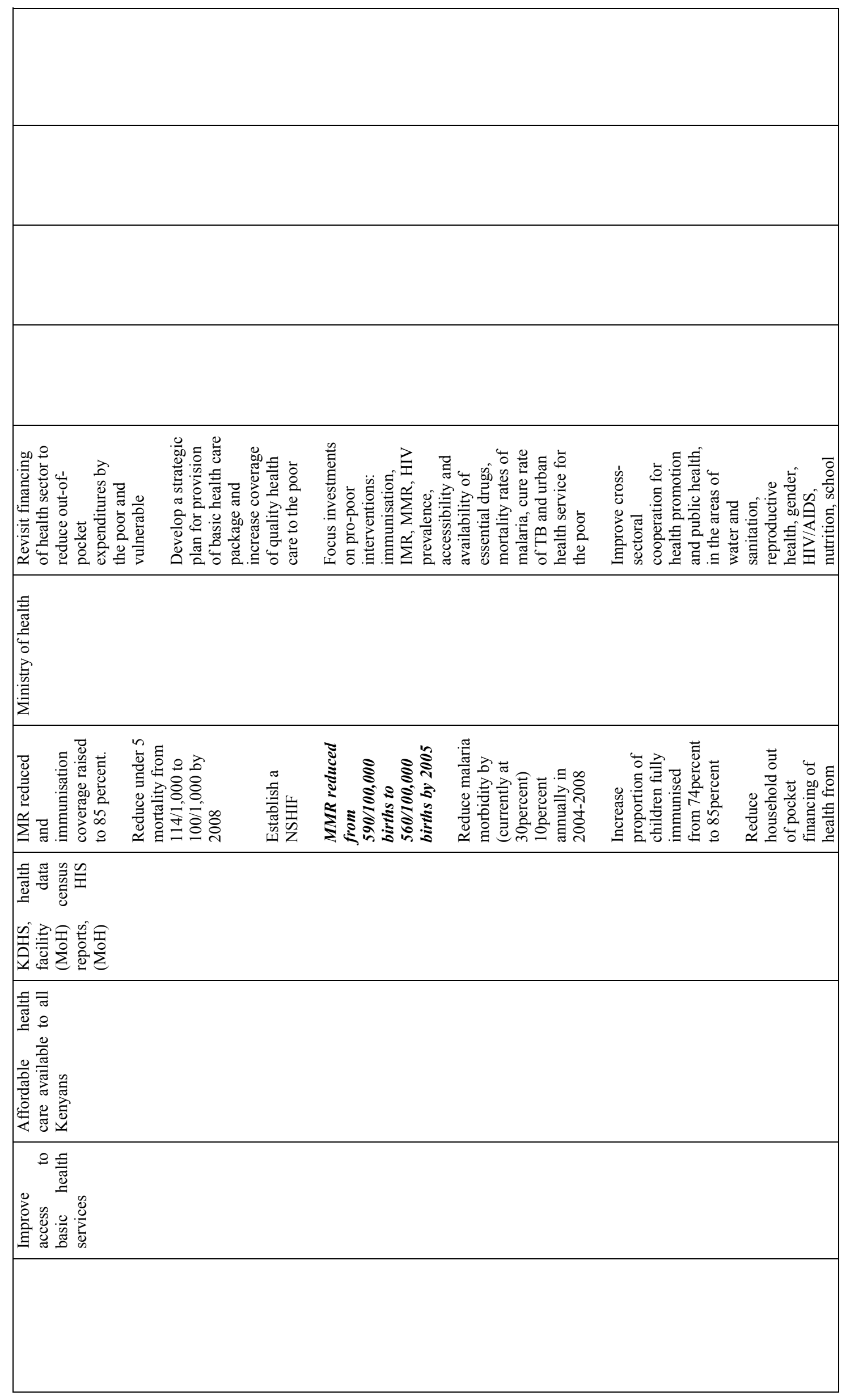

2 


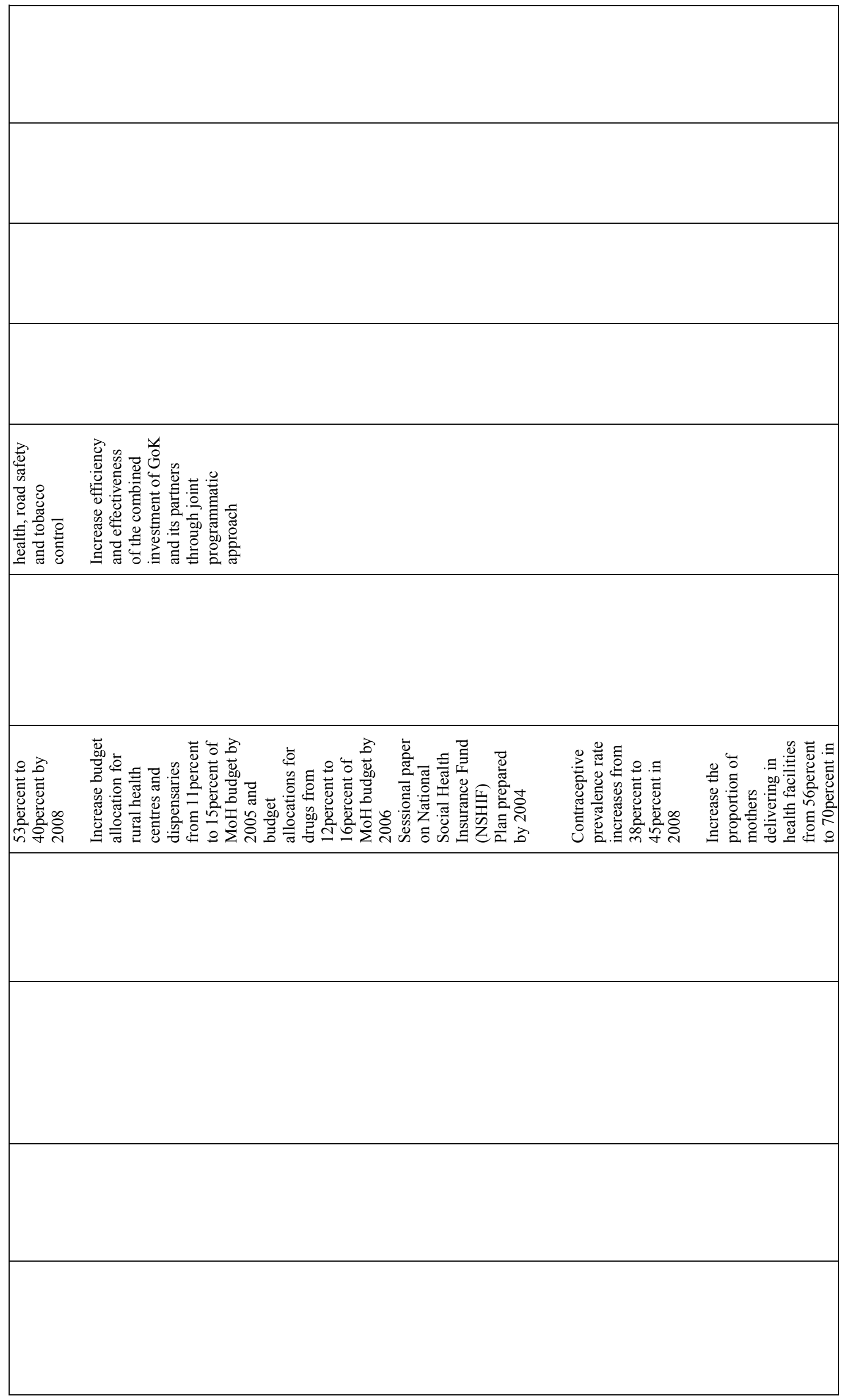




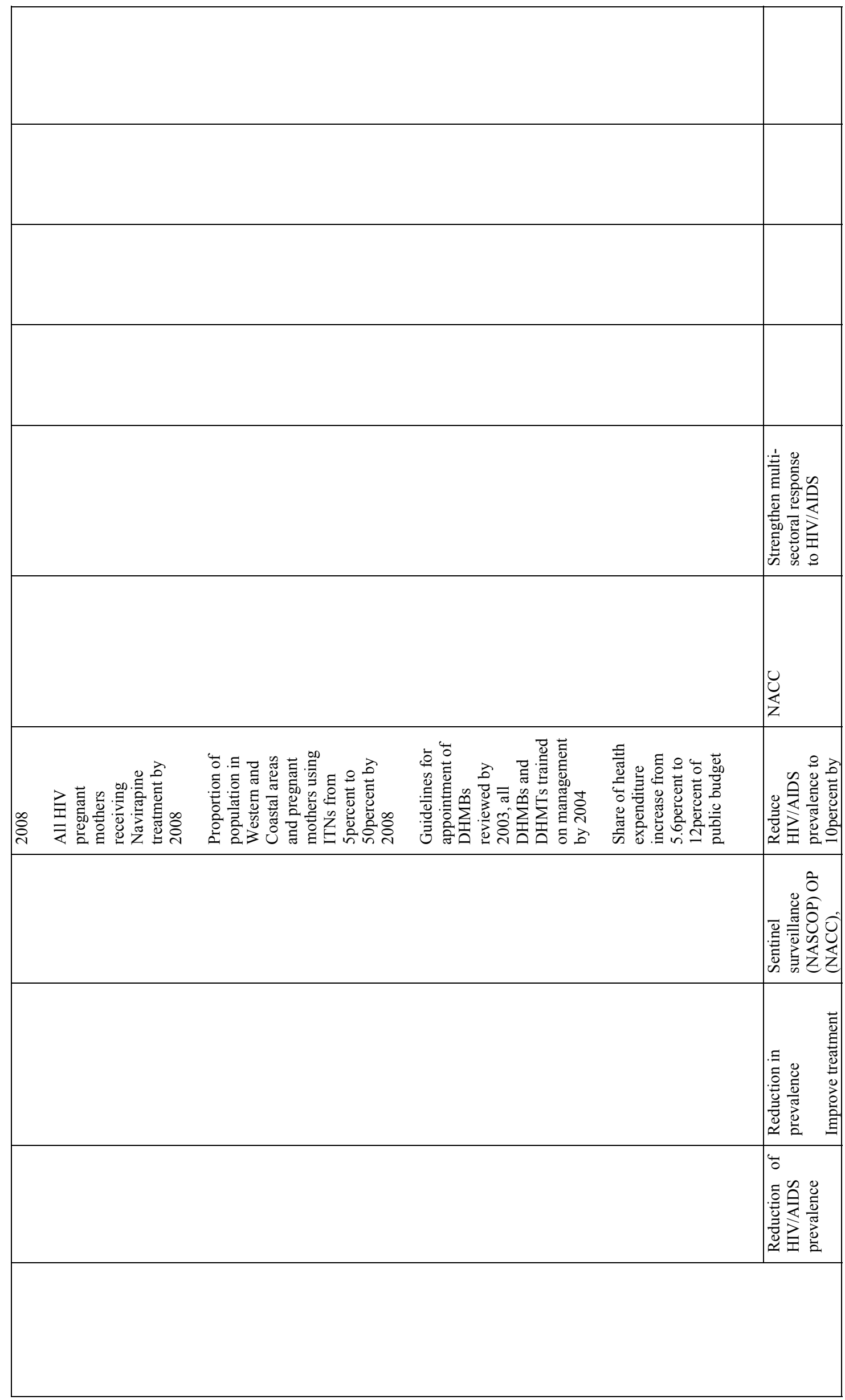




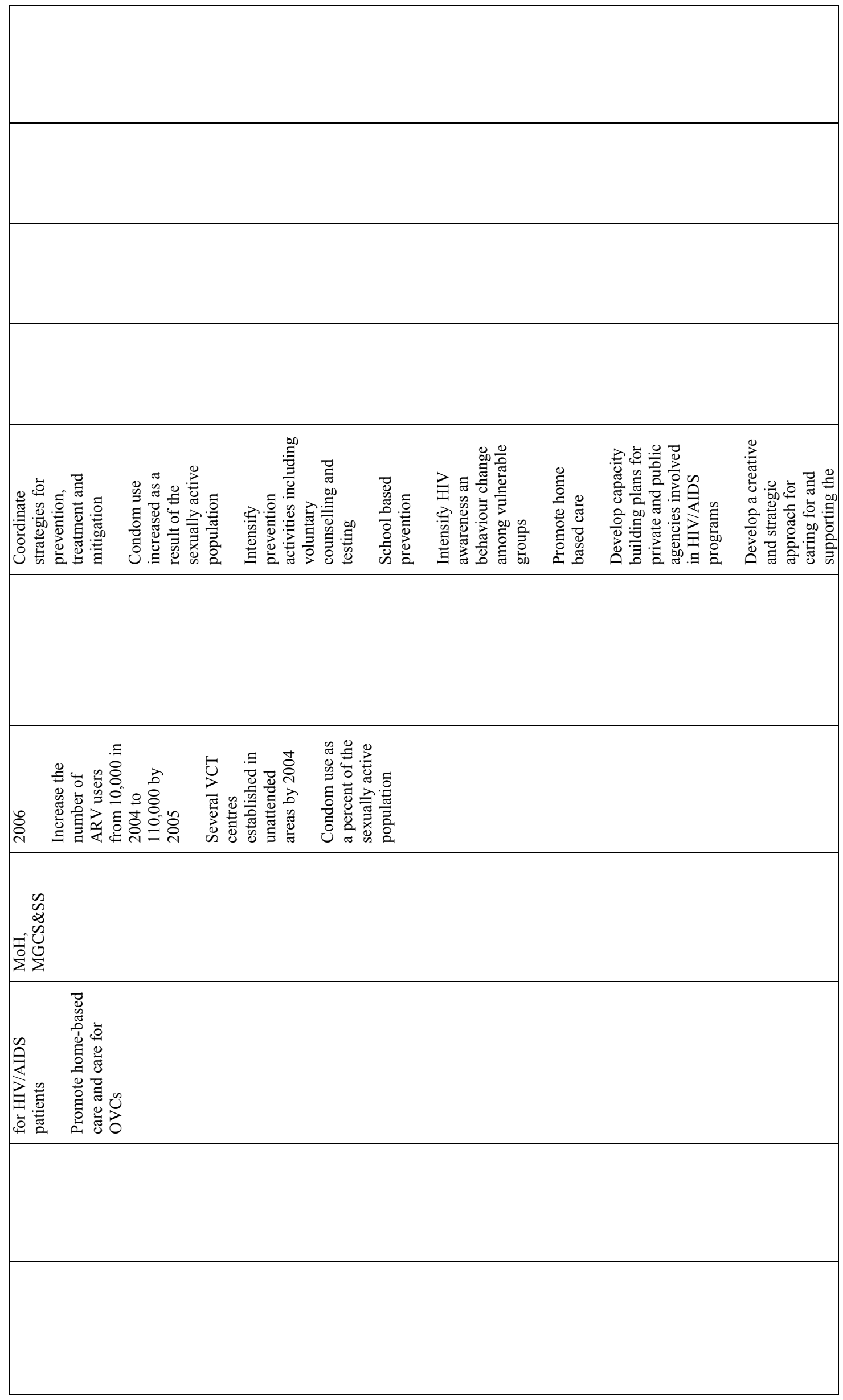




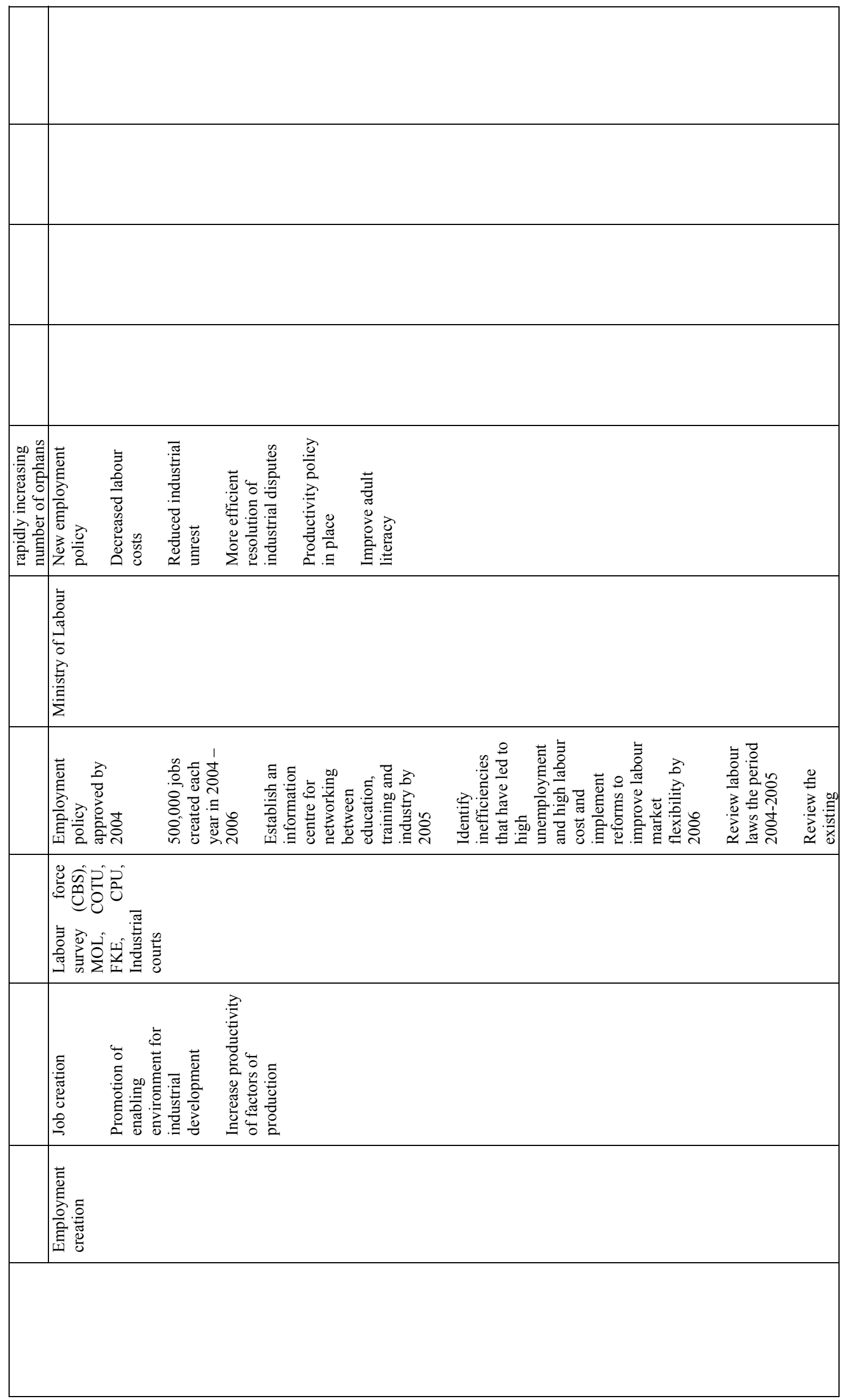




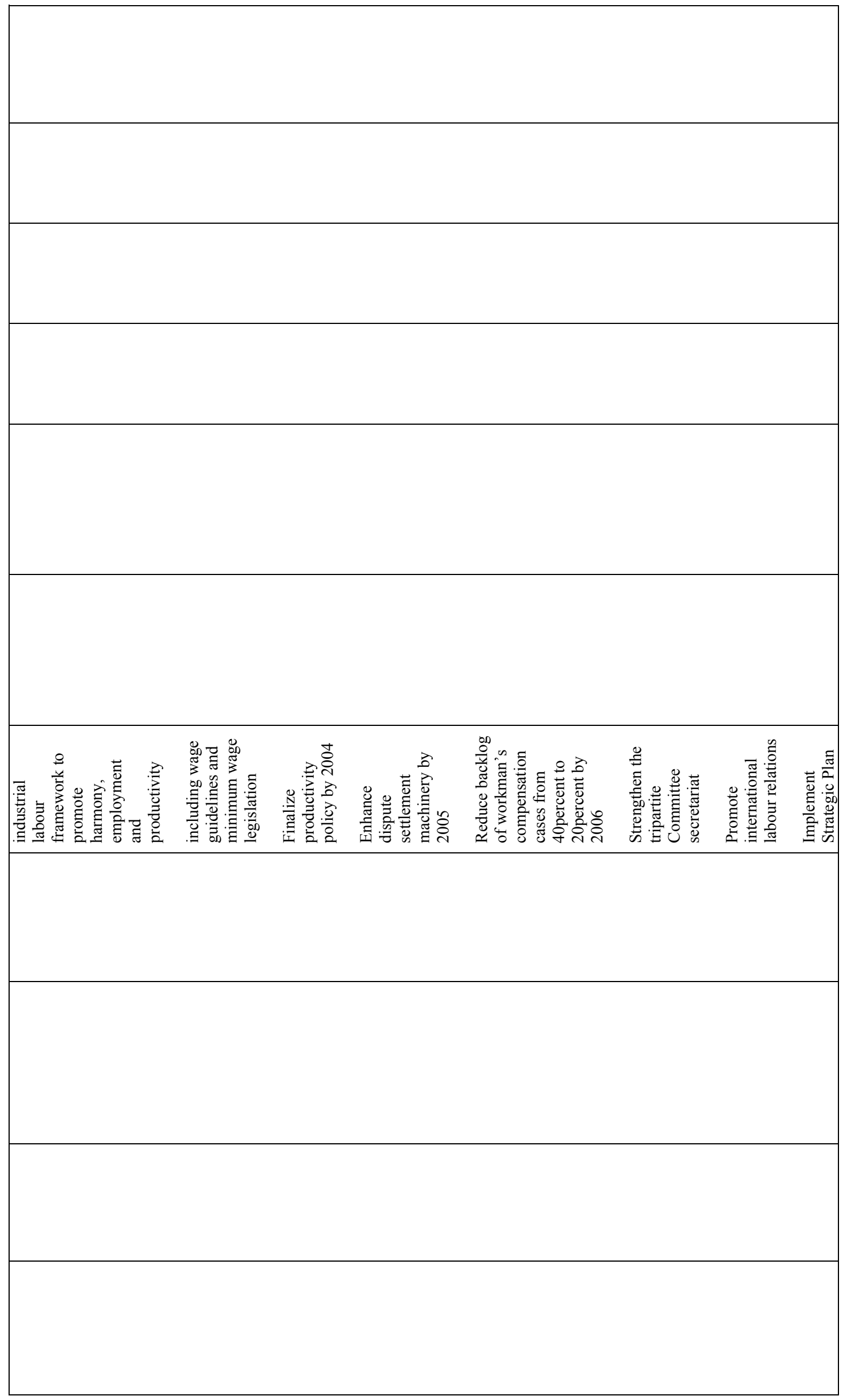




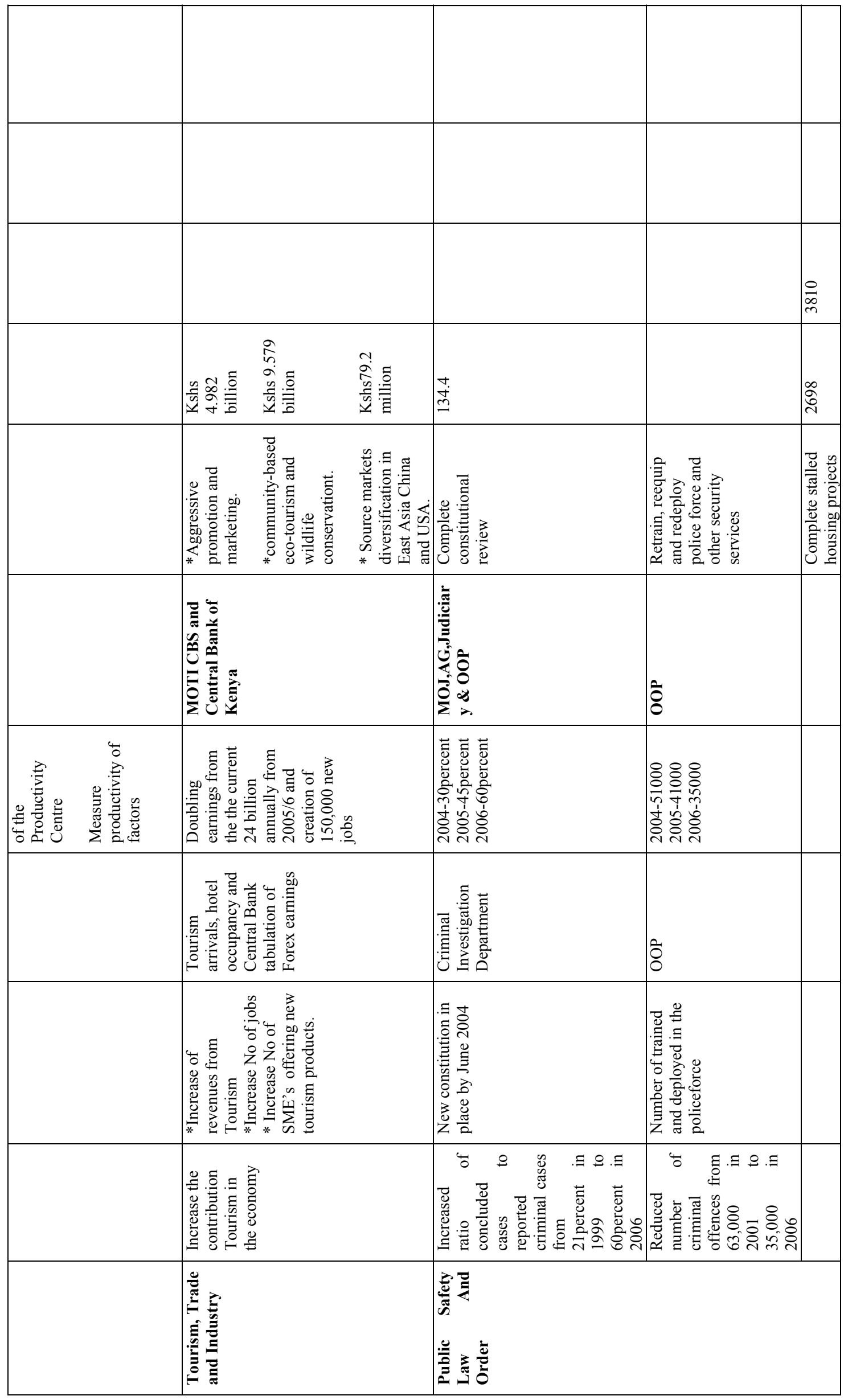




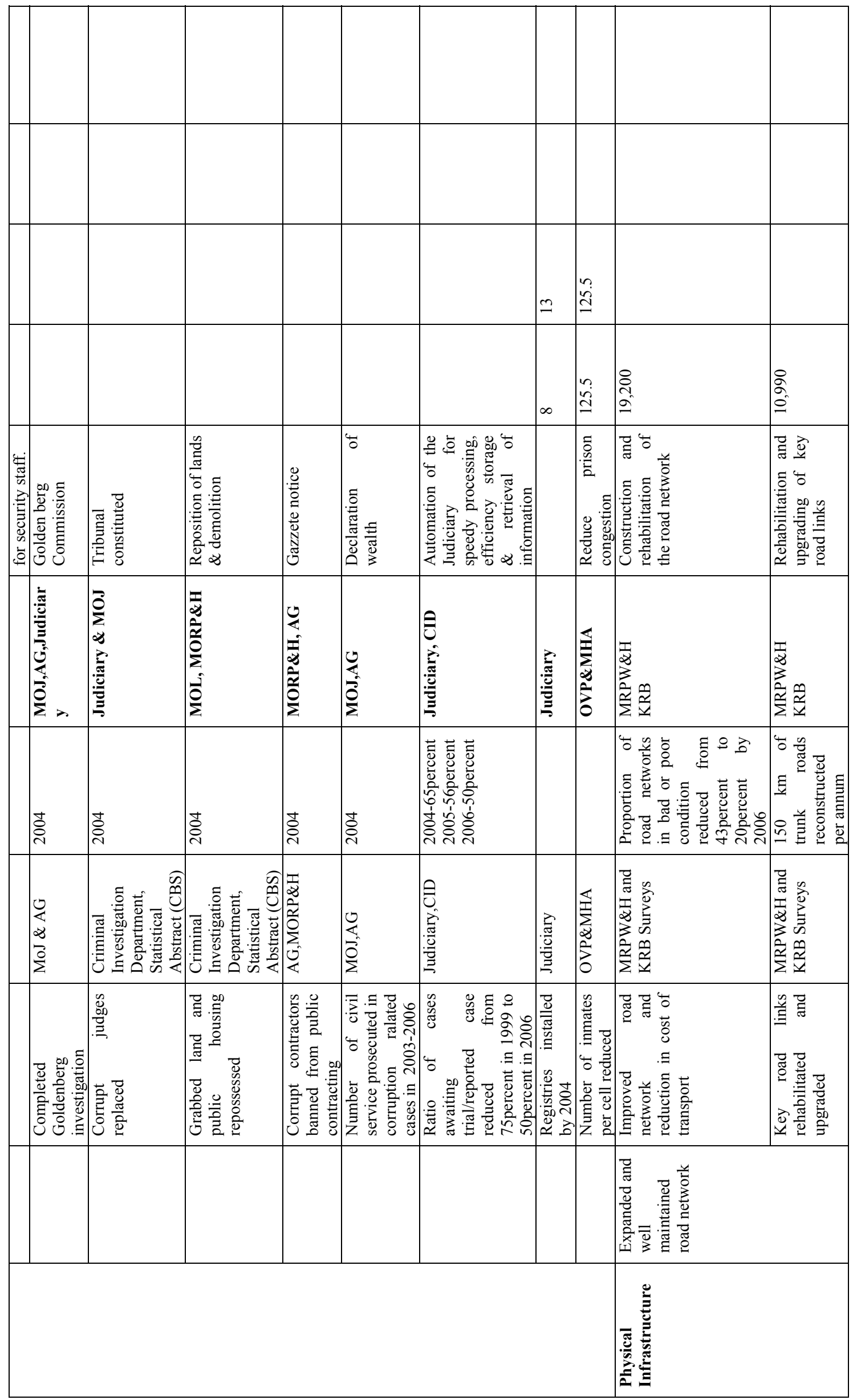




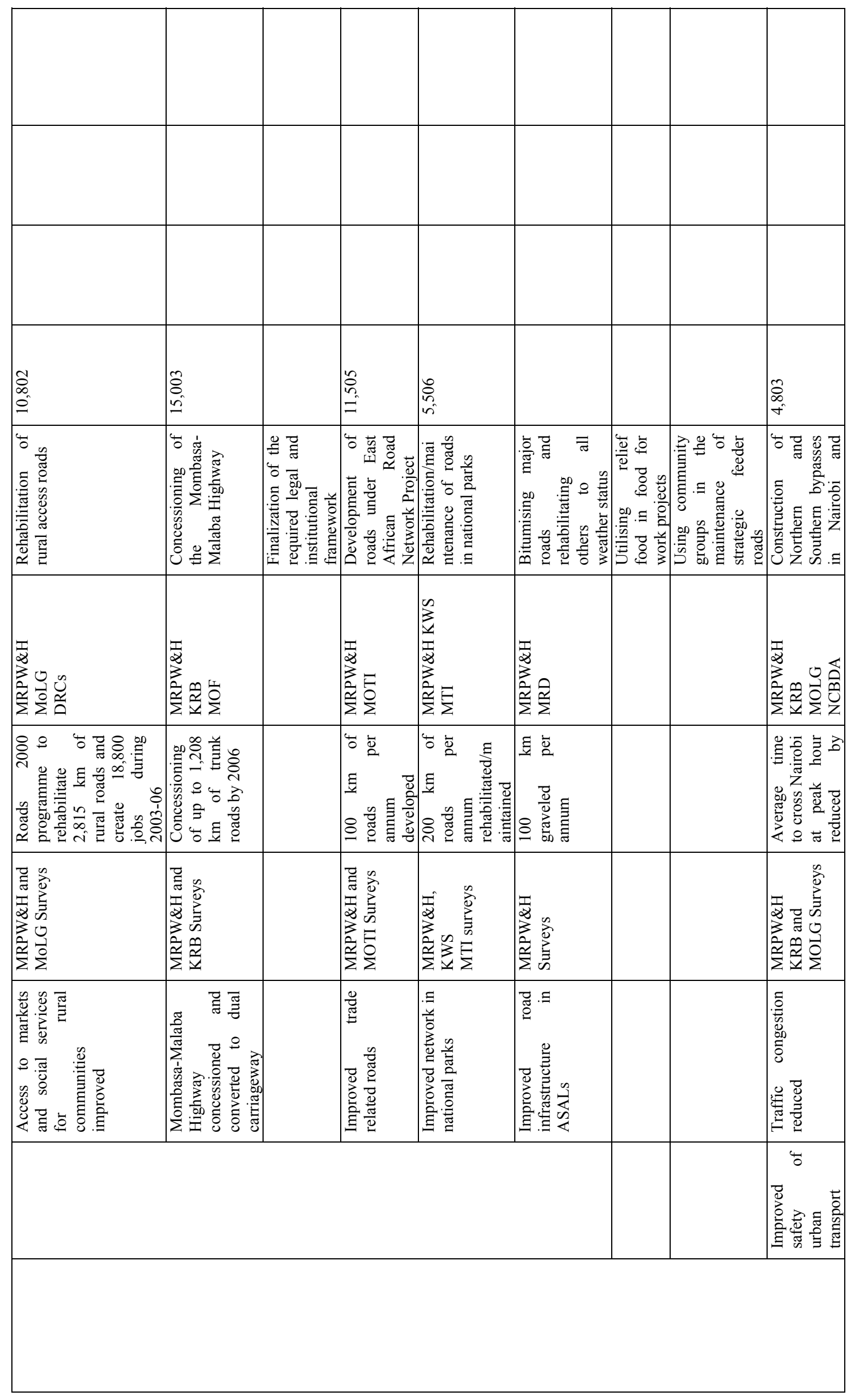




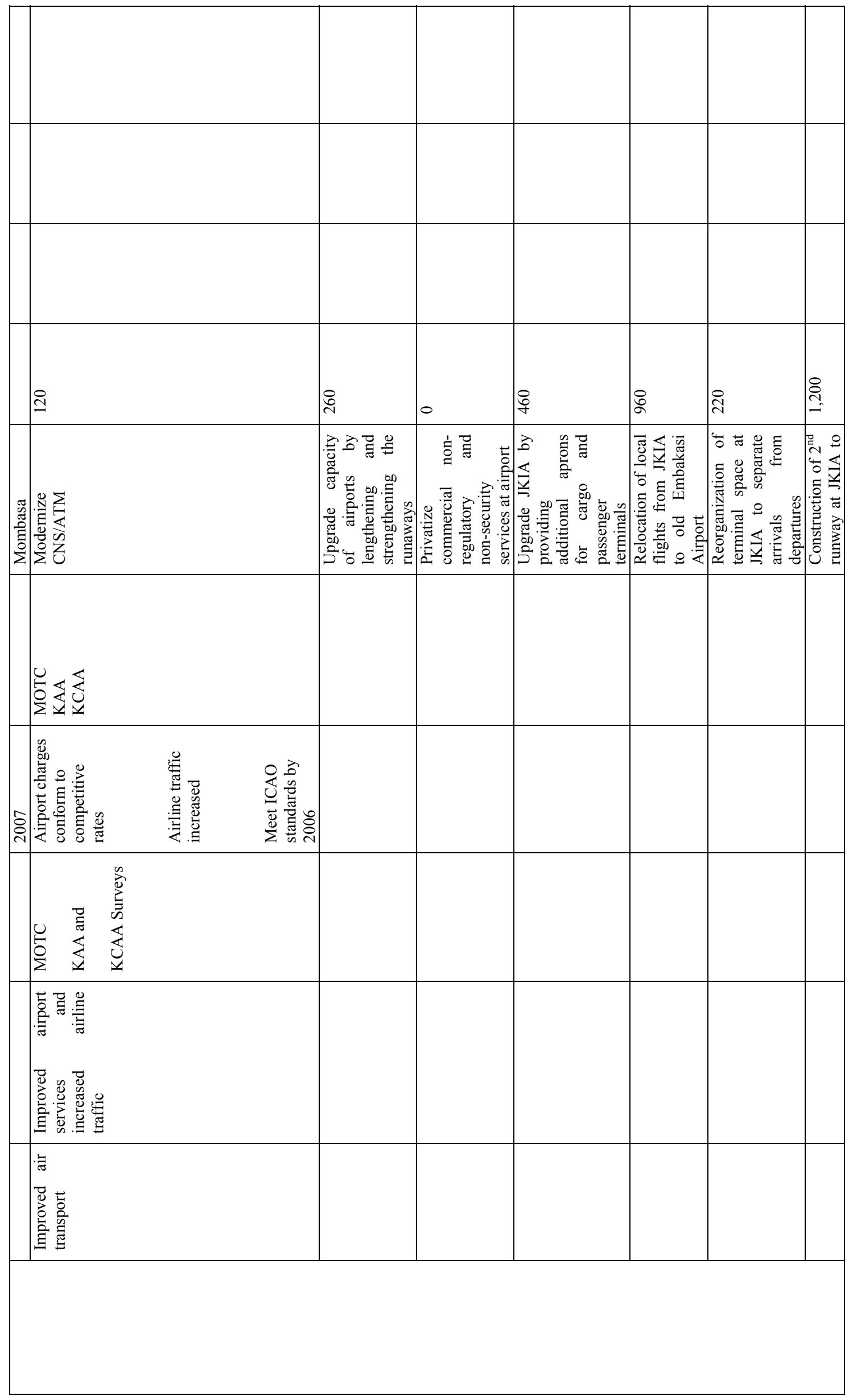




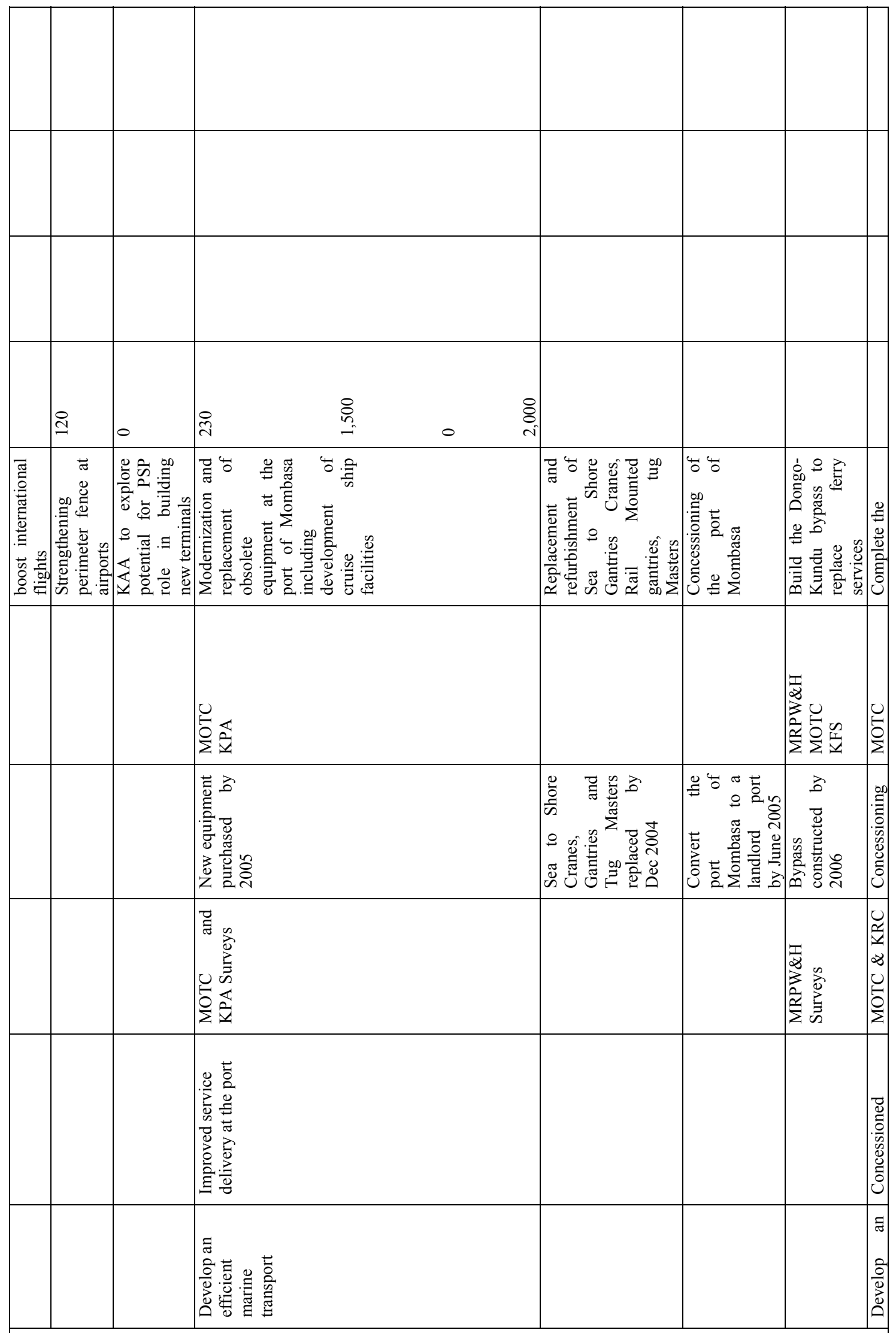

\section{$\infty$}




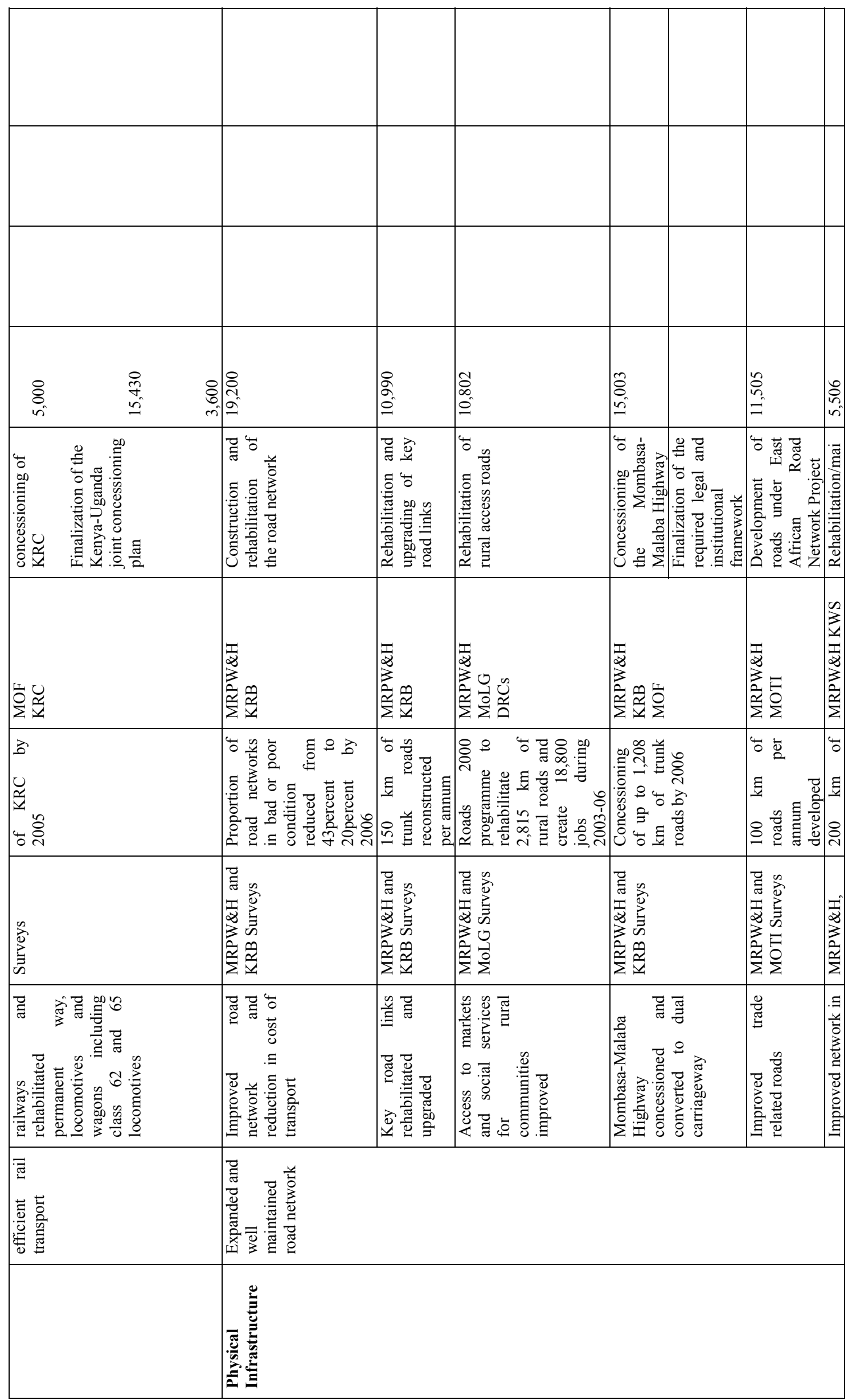




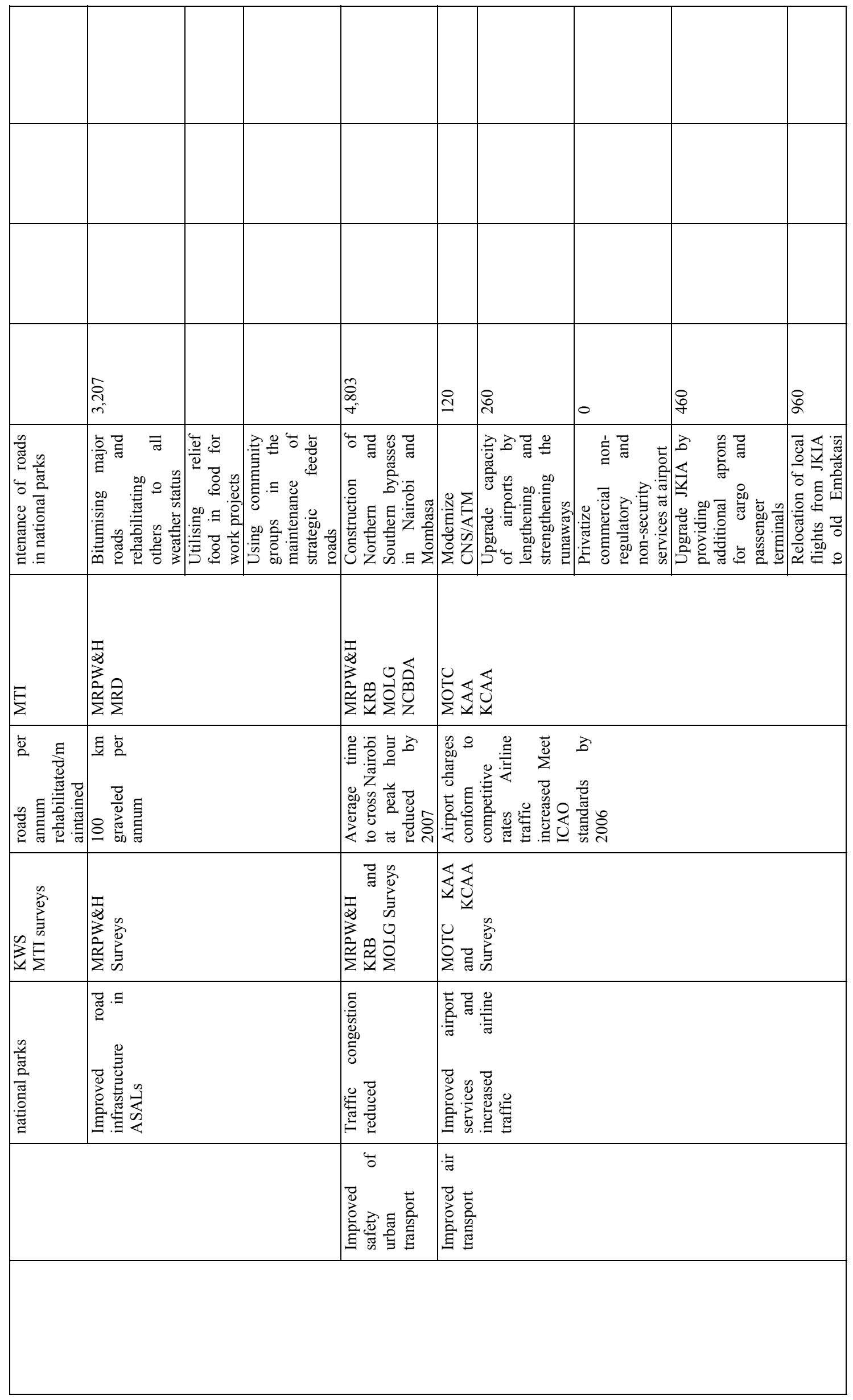




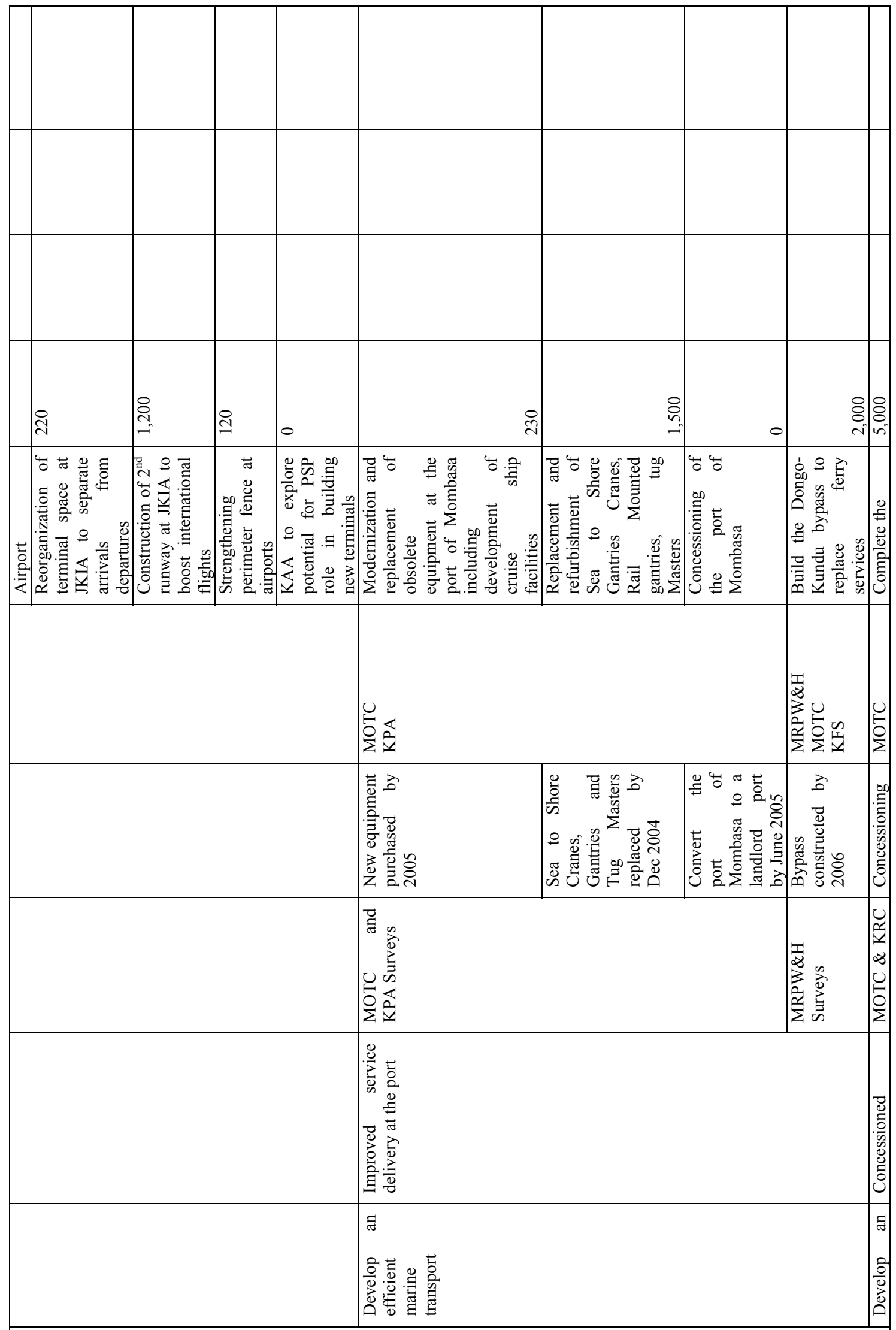

$\alpha$ 


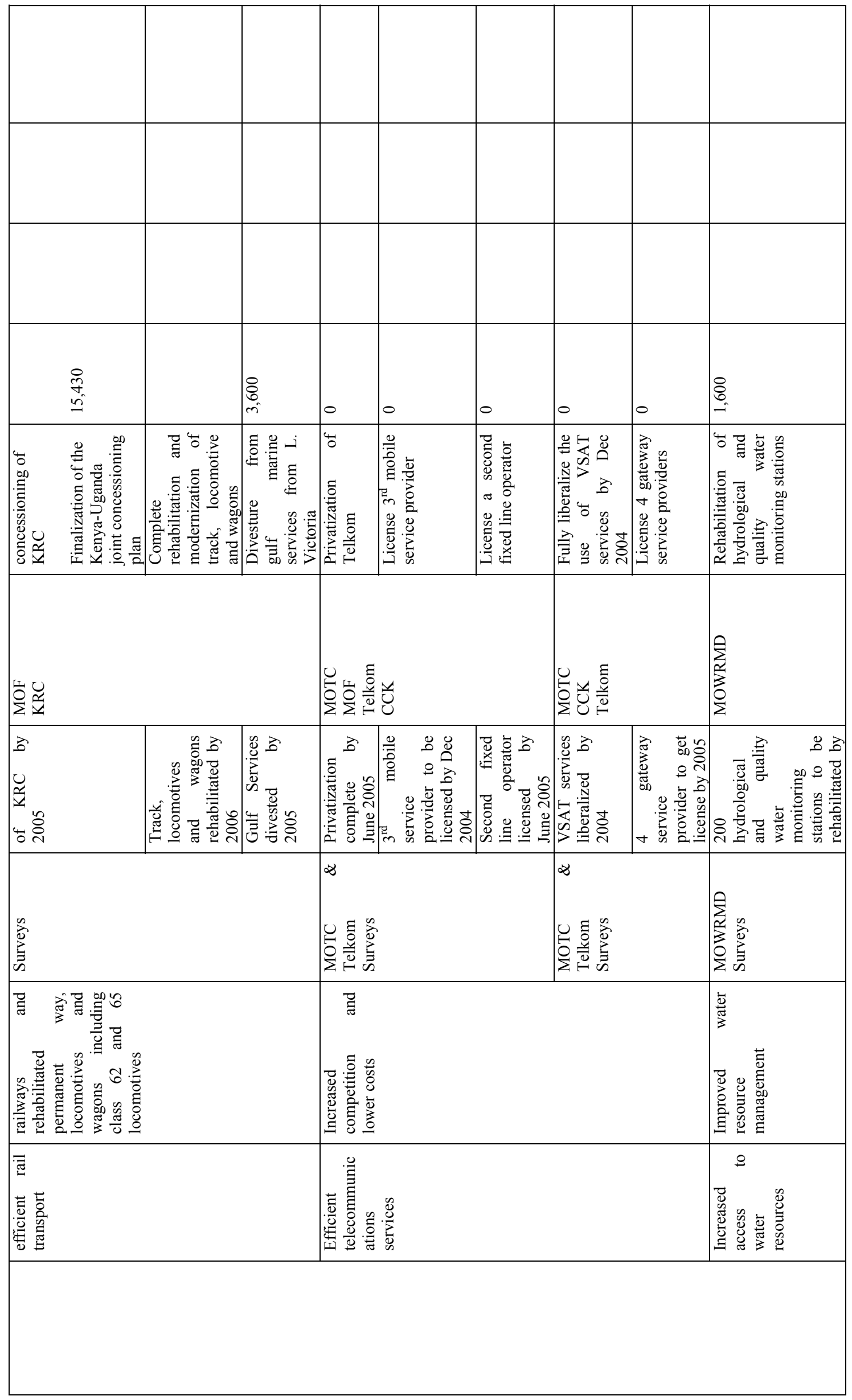

$a$ 


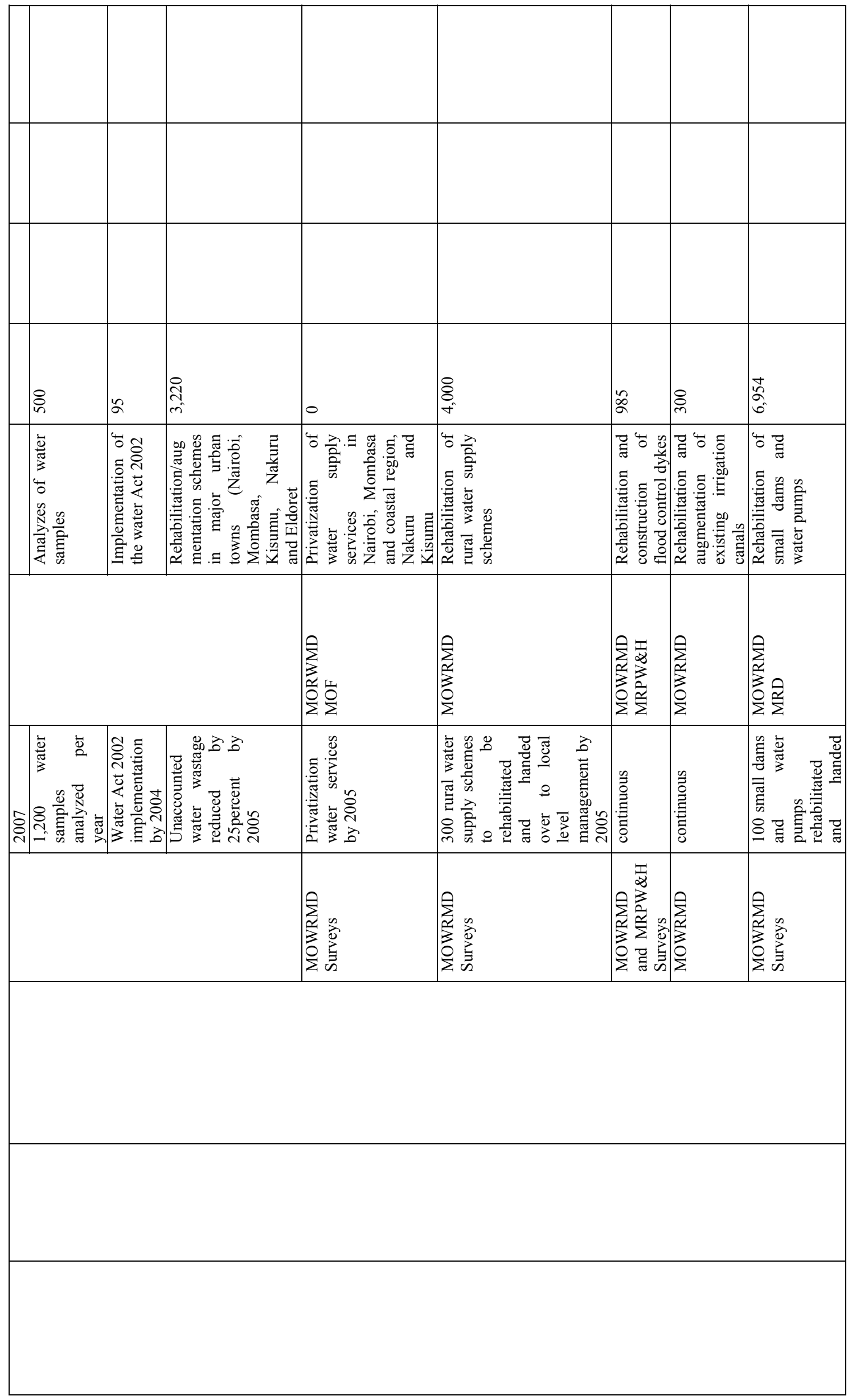




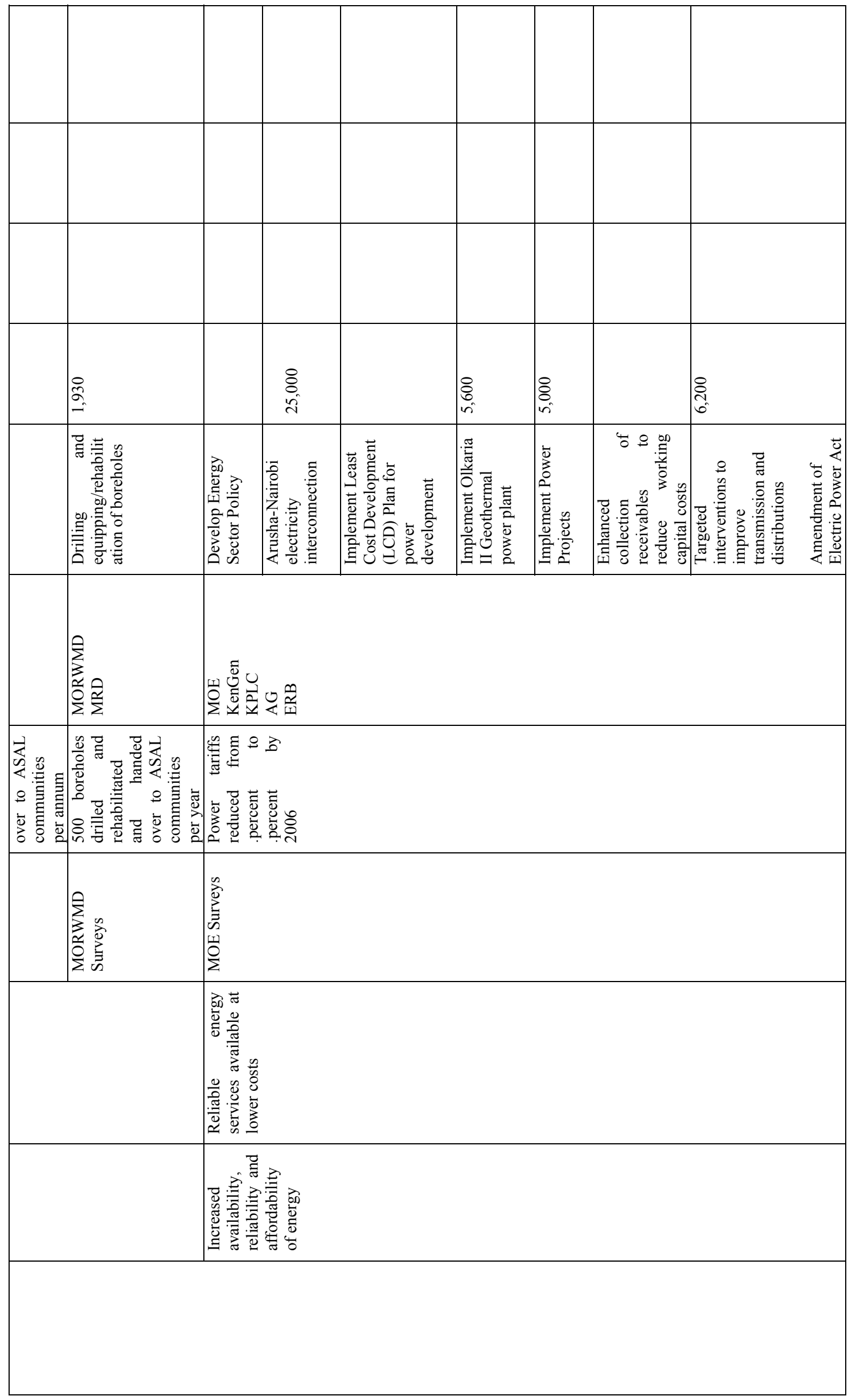




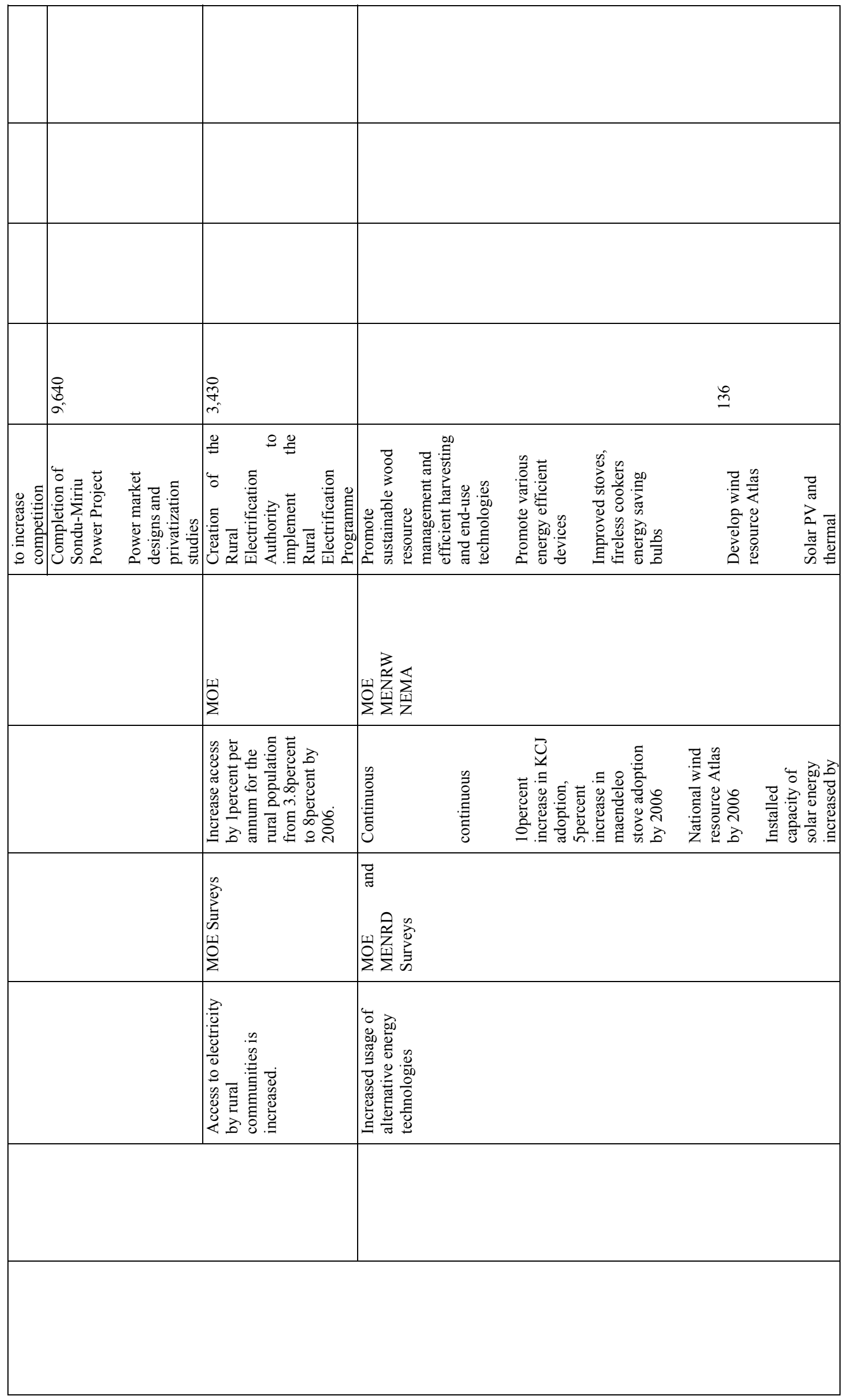




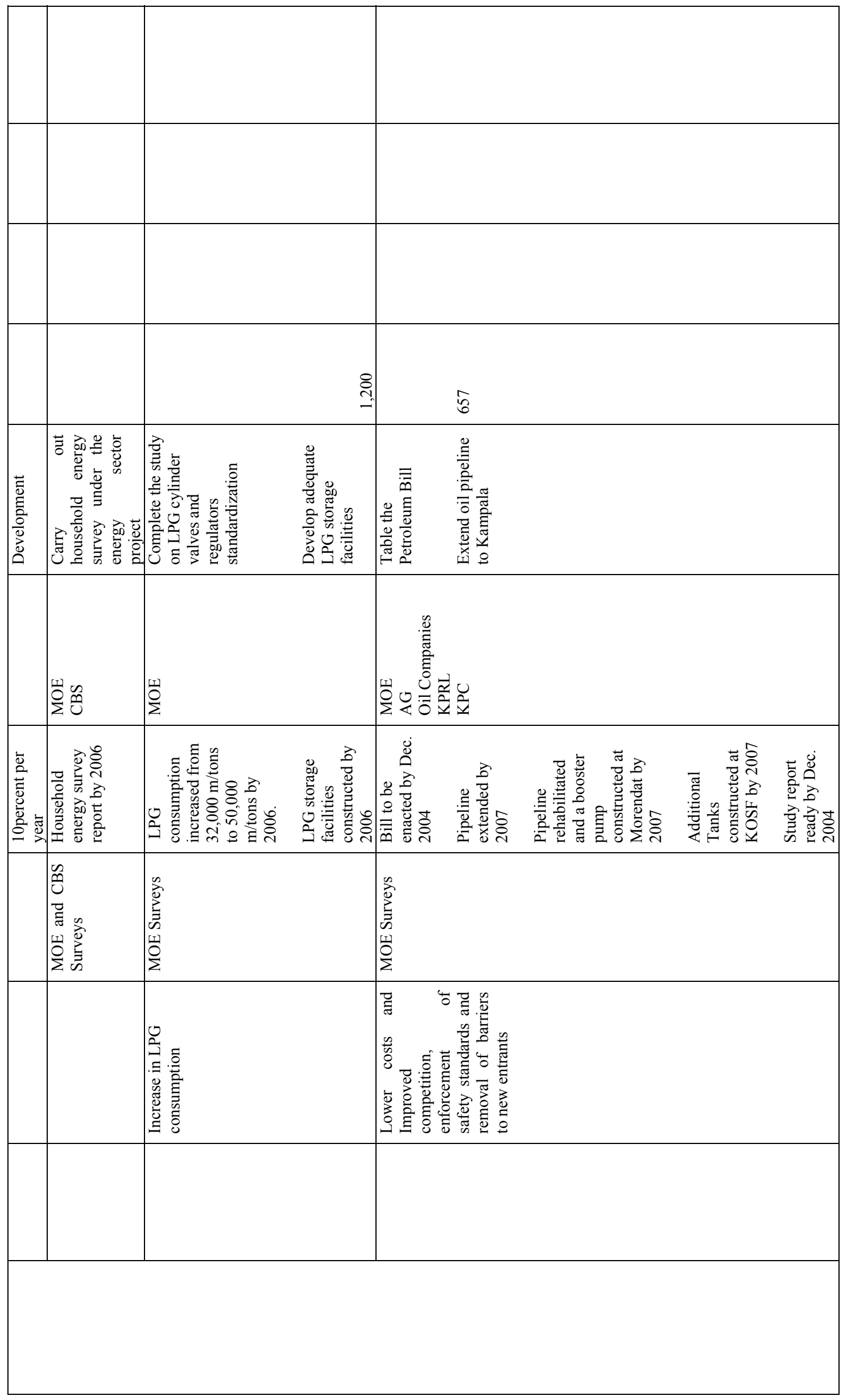




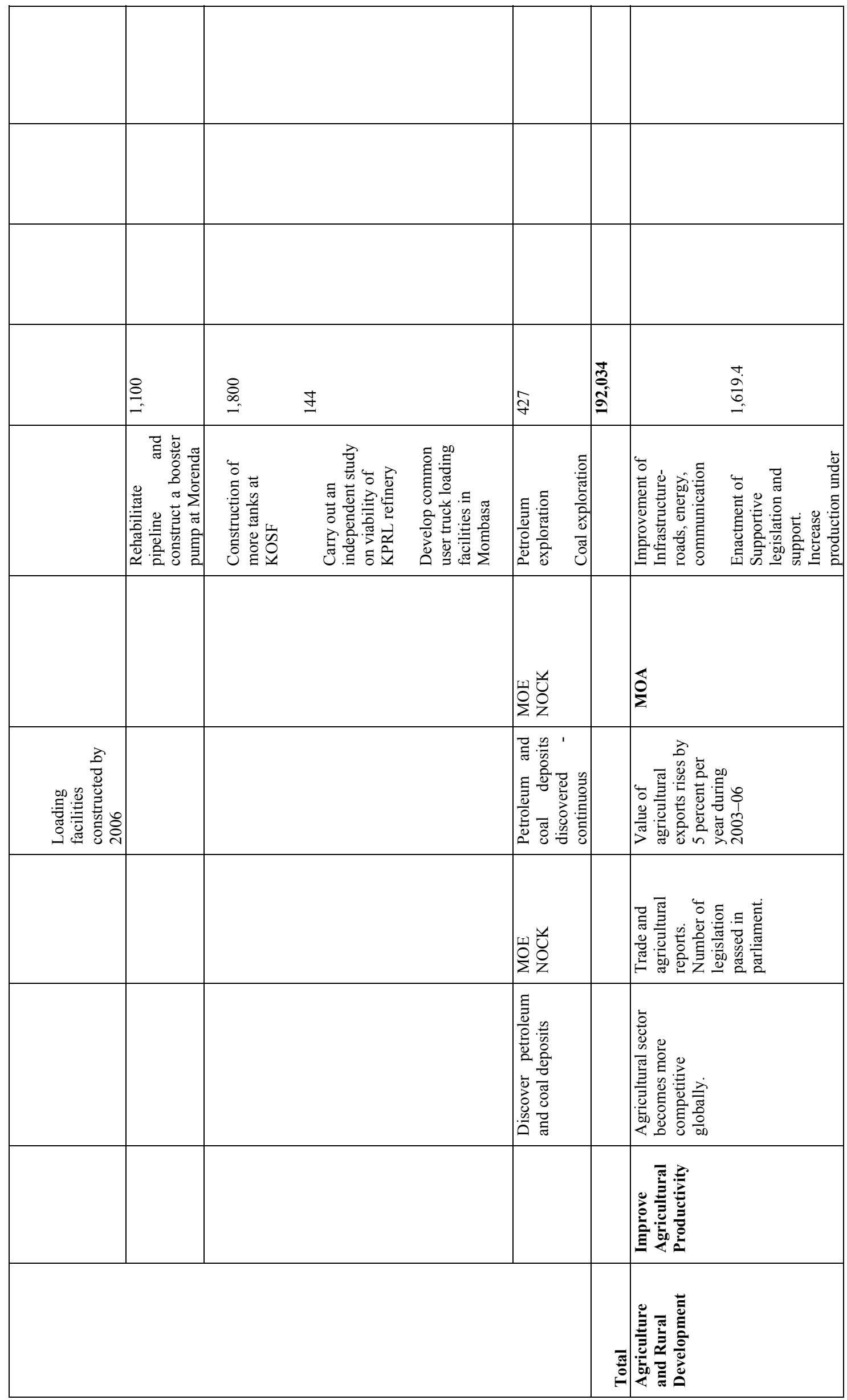

\section{๙}




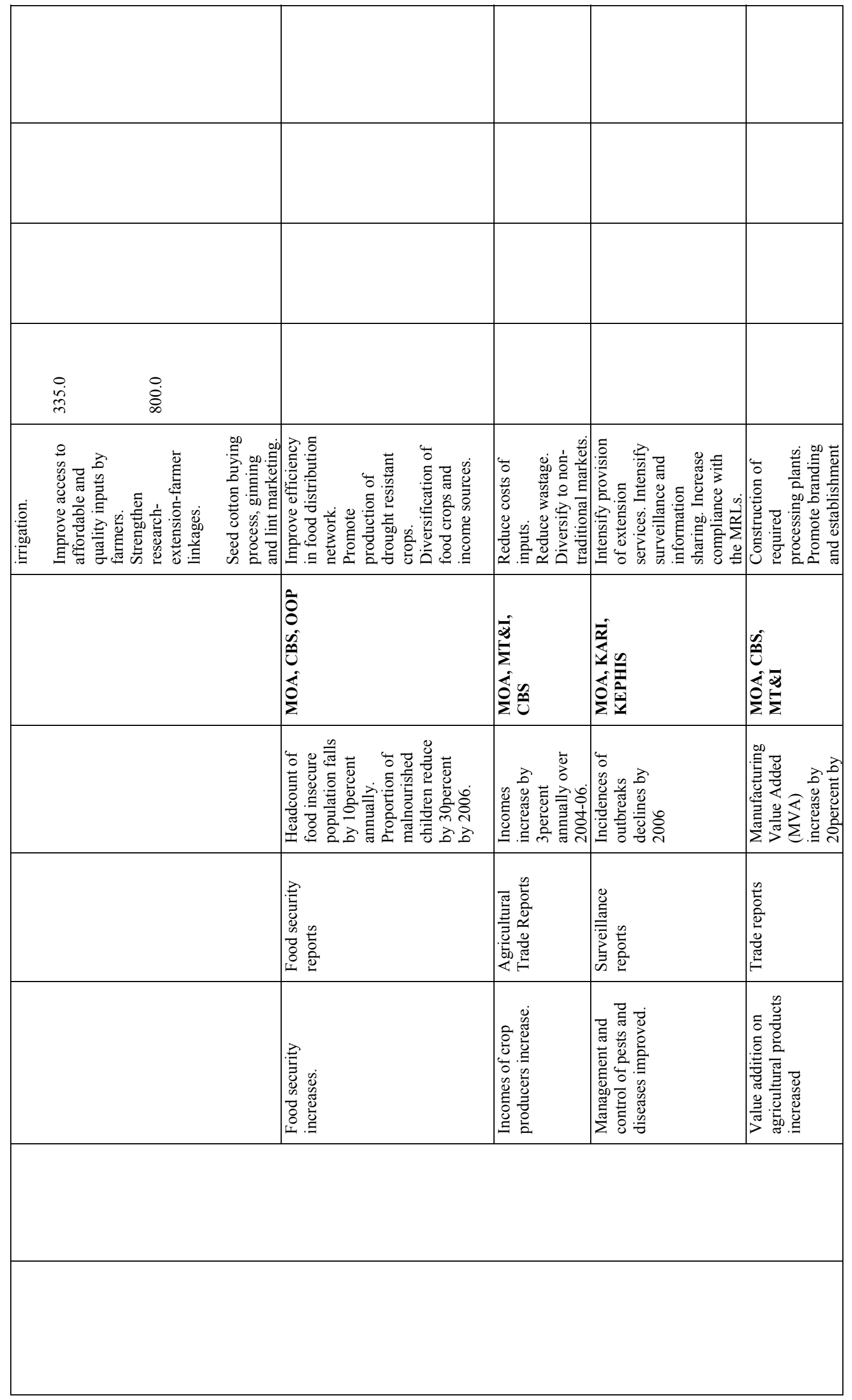




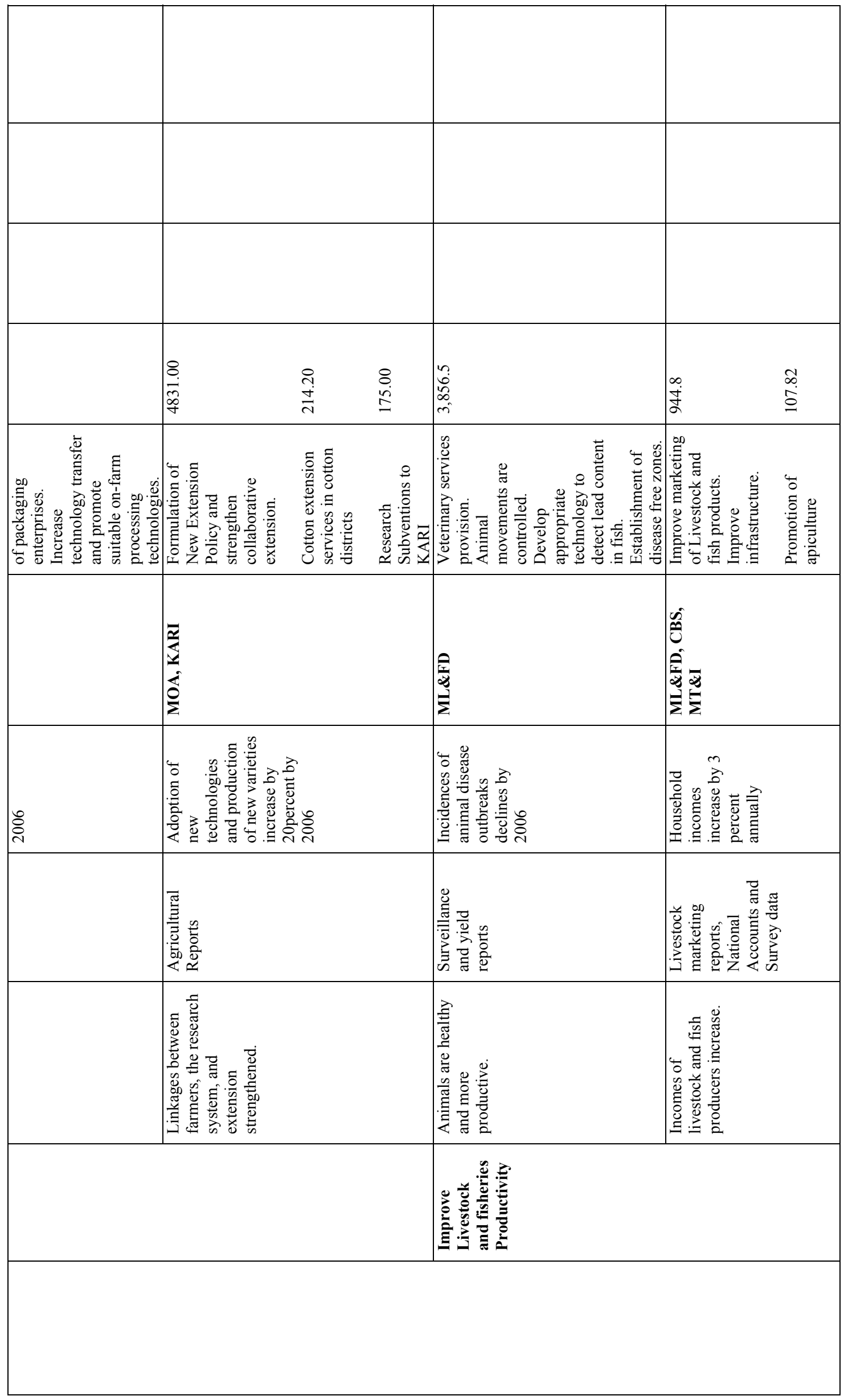

8 


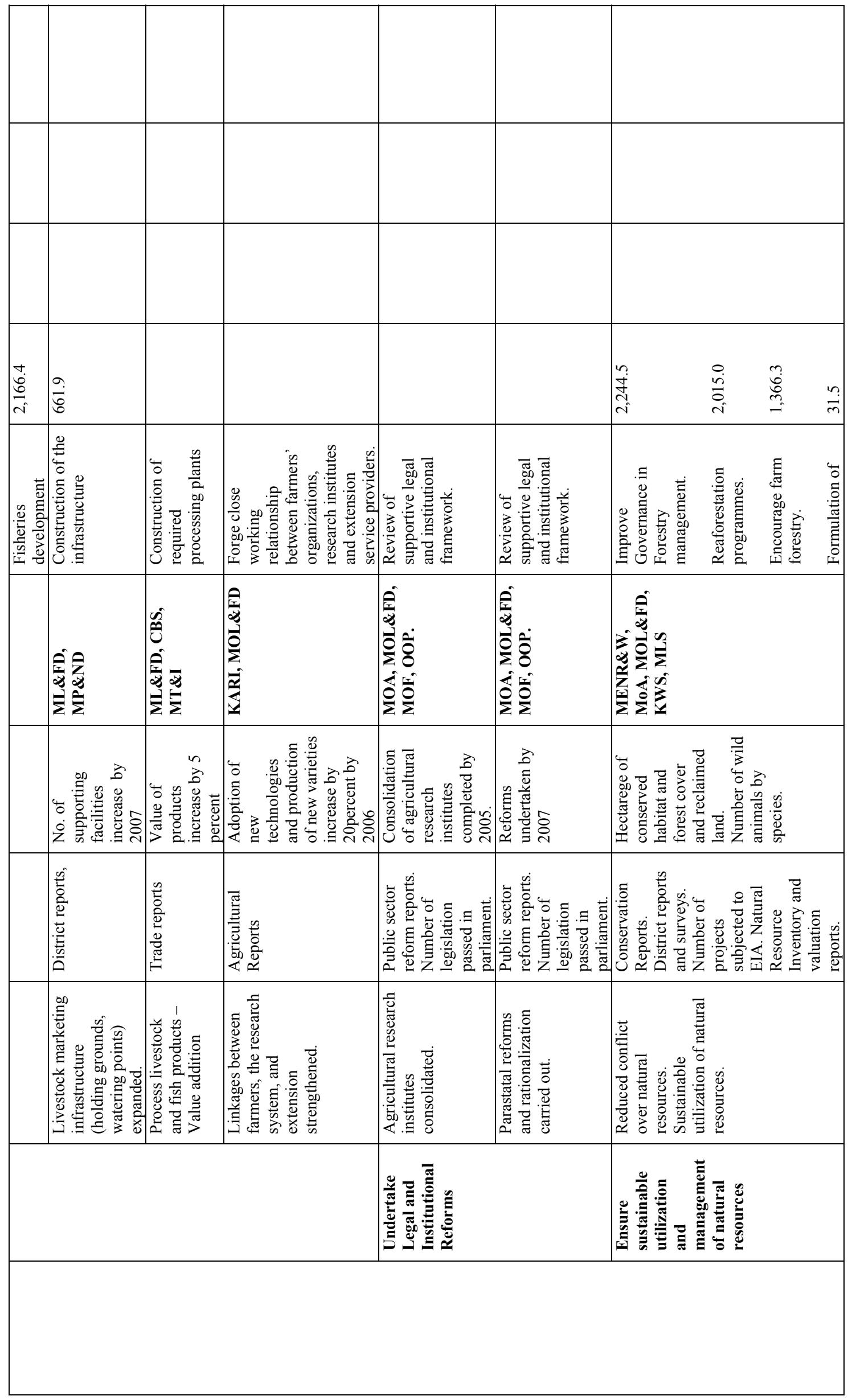




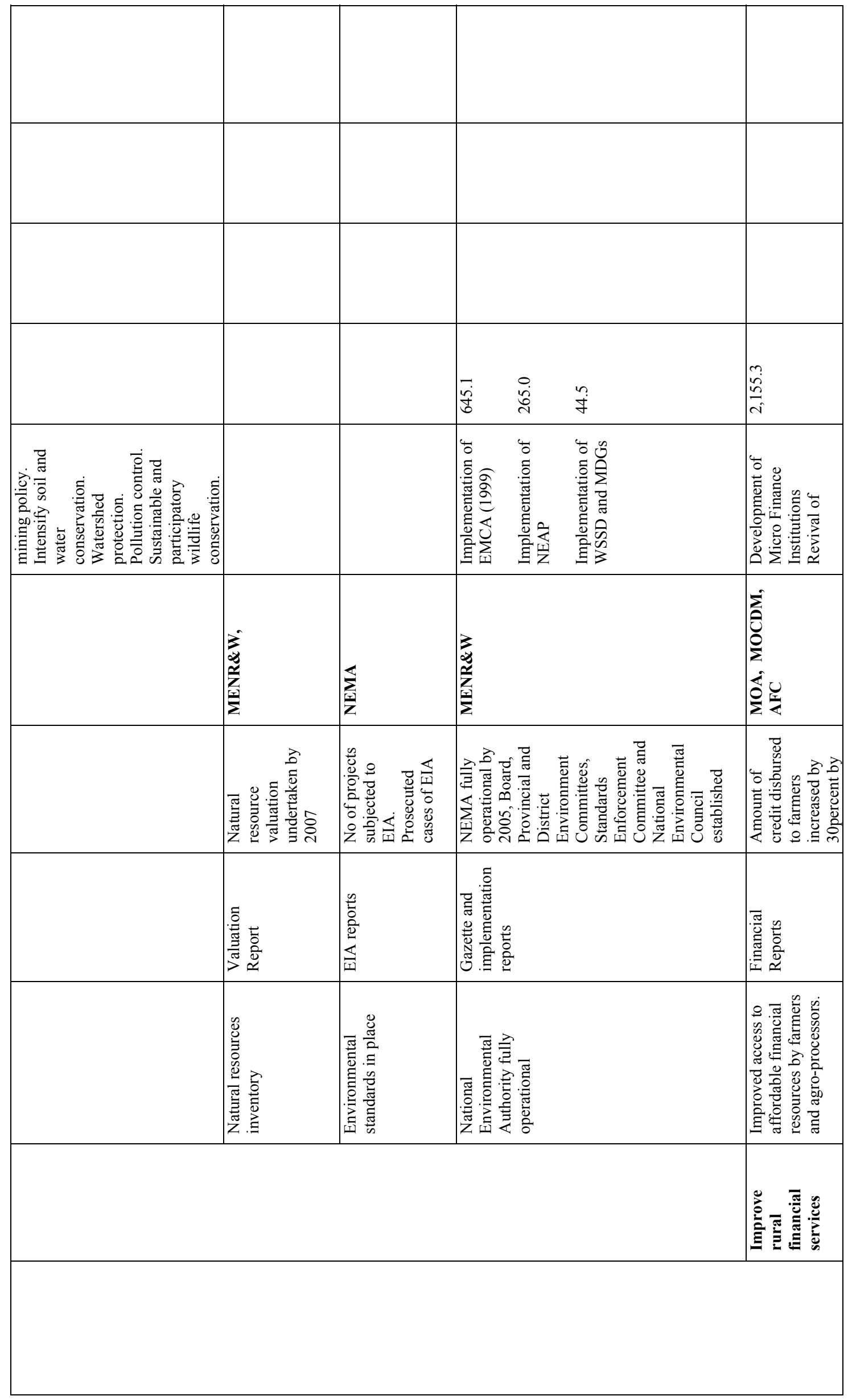




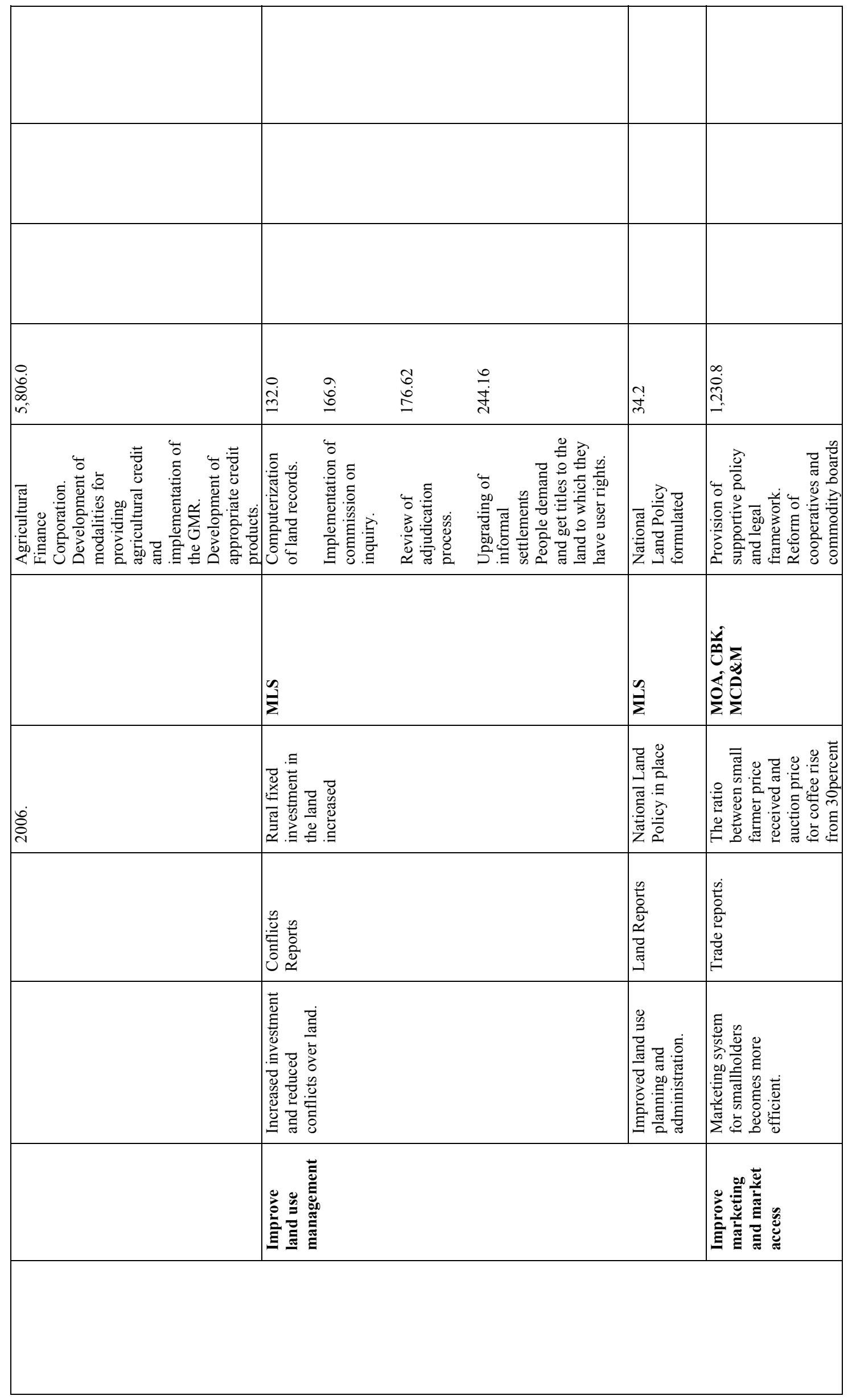




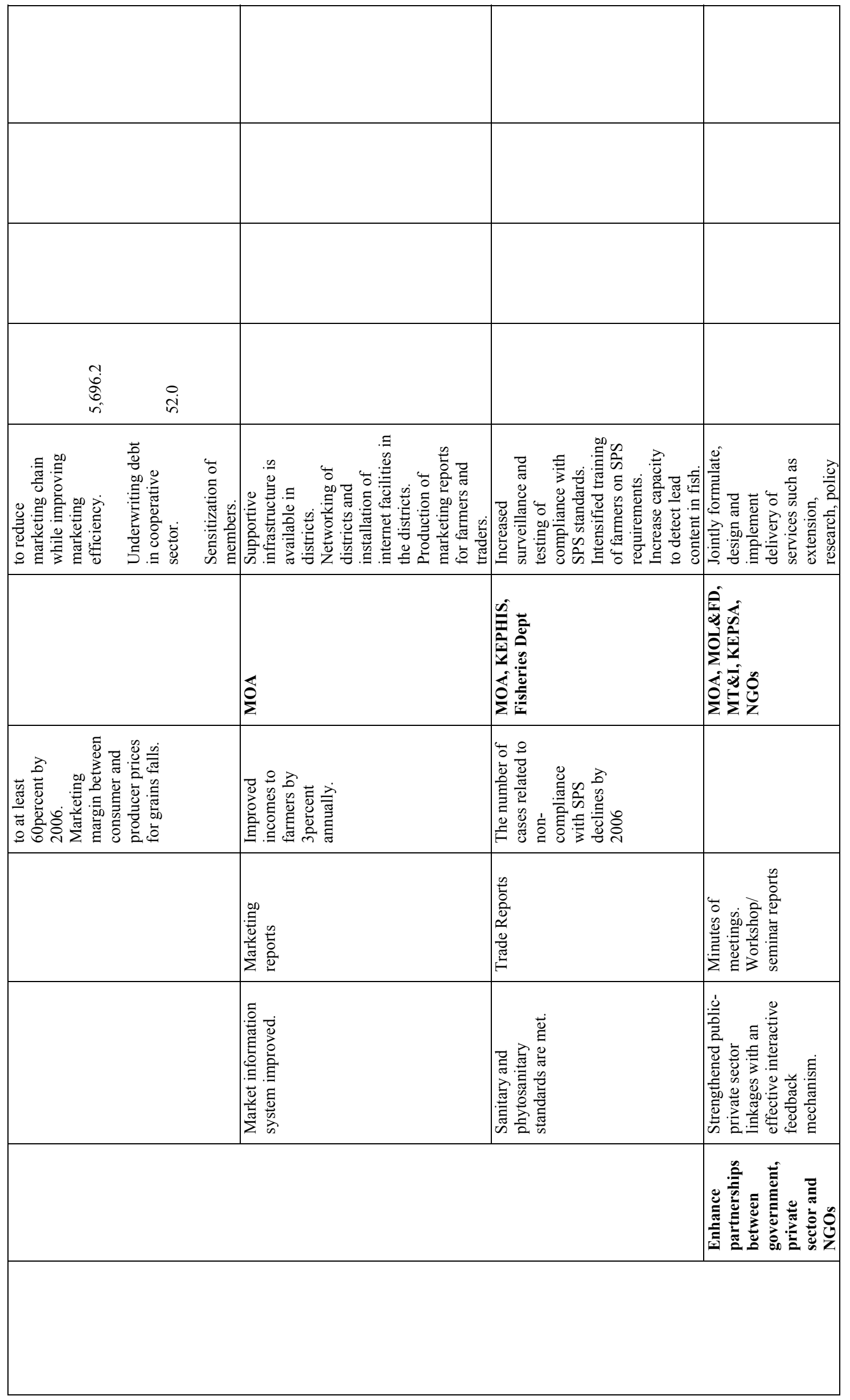




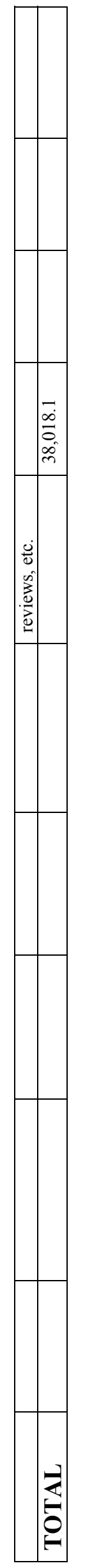

$\stackrel{n}{9}$ 


\section{Annex I: \\ Logical Framework Matrix for Kenya's Economic Recovery Strategy \\ (ERSWEC)}

February 12, 2004 


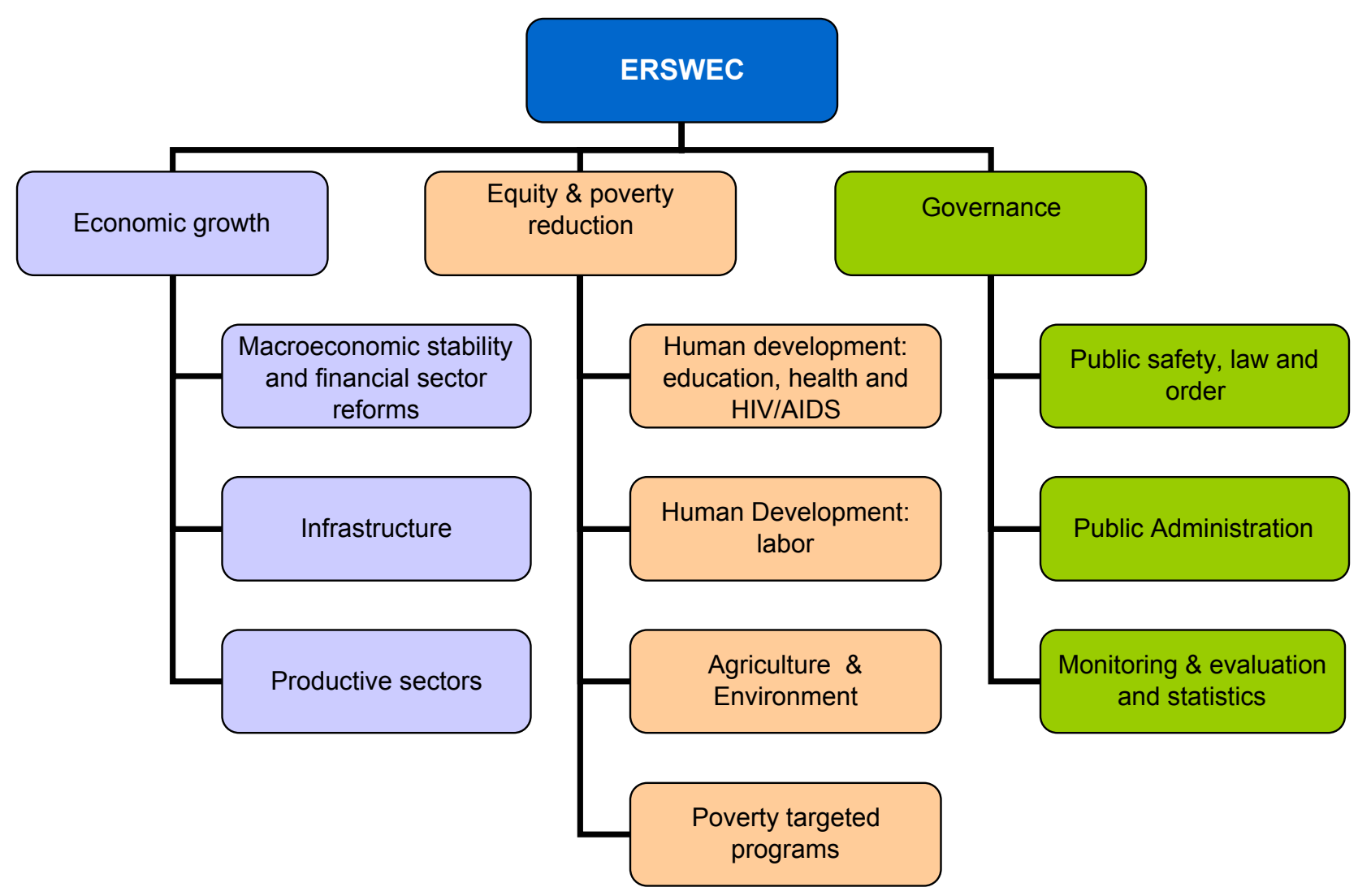

Table of Contents

Page

Summary and Selected Indicators

I. 3

PART A.1: ECONOMIC GROWTH Macroeconomic Framework and Financial Sector Reforms

I. 4

PART A.2: ECONOMIC GROWTH Infrastructure

I. 11

PART A.3: ECONOMIC GROWTH Productive Sectors

I. 16

PART B.1: EQUITY AND POVERTY REDUCTION Human Resource Development: Education, Health and HIVIAIDS

I. 18

PART B.2: EQUITY AND POVERTY REDUCTION Human Resource Development: Labor

I. 21

PART B.3: EQUITY AND POVERTY REDUCTION Agriculture, Rural Development and Environment

I. 22

PART B.4: EQUITY AND POVERTY REDUCTION Poverty Targeted Programs

I. 26

PART C.1: GOVERNANCE Safety, Law and Order

I. 29

PART C.2: GOVERNANCE Public Administration

I. 31

PART C.3: GOVERNANCE Monitoring and Evaluation

I. 33 
Logical Framework Matrix for Kenya's Economic Recovery Strategy for Wealth and Employment Generation (ERS) SUMMARY AND SELECTED INDICATORS

\begin{tabular}{|c|c|c|c|c|c|}
\hline \multicolumn{2}{|c|}{ Narrative } & $\begin{array}{l}\text { Indicators } \\
\text { from ....to ....bv(date) }\end{array}$ & $\begin{array}{l}\mathbf{M} \& \mathbf{E} \\
\text { data source and responsibility }\end{array}$ & $\begin{array}{r}\text { Page } \\
\text { number }\end{array}$ & Matrix \\
\hline \multicolumn{6}{|c|}{ Objectives } \\
\hline $\mathrm{O} 1$ & Economic growth & $\begin{array}{l}\text { GDP growth rate increases from } 1.2 \% \text { in } 2002 / 03 \text { to } \\
1.9 \% \text { in } 2003 / 04 \text { to } 3.1 \% \text { in } 2004 / 05 \text { and to } 4.5 \% \text { by } \\
2006 / 07\end{array}$ & Annual Economic Survey (CBS) & $\mathrm{I}-4$ & $\mathrm{~A}$ \\
\hline \multirow[t]{2}{*}{$\mathrm{O} 2$} & Human development and poverty redution & $\begin{array}{l}\text { Reduce proportion of the people below the absolute } \\
\text { poverty lines (Kenya and \$1PPP) by } 10 \% \text { by } 2006 \\
\text { from } 57 \% \text { in } 1997 \text { (MDG1) }\end{array}$ & $\begin{array}{l}\text { Kenya Living Standard Survey-KLSS } \\
\text { (CBS) (in design stage) }\end{array}$ & $\mathrm{I}-18$ & B \\
\hline & & $\begin{array}{l}\text { Reduce proportion of people living in hunger by } 10 \% \\
\text { by } 2006 \text { (MDG2) }\end{array}$ & MoA, WFP, FAO, KLSS & & \\
\hline $\mathrm{O} 3$ & Governance & $\begin{array}{l}\text { Proportion of corruption cases leading to conviction } \\
\text { increased }\end{array}$ & Criminal Investigation Department & I-29 & $\mathrm{C}$ \\
\hline \multicolumn{6}{|c|}{ Development outcomes } \\
\hline$\overline{\mathrm{DO} 1}$ & Macroeconomic stability & $\begin{array}{l}\text { Overall fiscal deficit (including grants) reduced to } 3 \text {. } \\
\% \text { GDP by } 2006 / 07\end{array}$ & Quarterly Budget Review (Treasury) & $\mathrm{I}-4$ & A.1 \\
\hline $\mathrm{DO} 2$ & Financial sector development & $\begin{array}{l}\text { Stock of non-performing loans reduced by one third } \\
\text { duirng 2003-2006 }\end{array}$ & Monthly Central Bank Reports & $\mathrm{I}-4$ & A.1 \\
\hline $\mathrm{DO} 3$ & $\begin{array}{l}\text { Increased private sector participation in } \\
\text { infrastructure }\end{array}$ & $\begin{array}{l}\text { Proportion of population with access to infrastructure } \\
\text { services expanded }\end{array}$ & & I-11 & A.2 \\
\hline $\mathrm{DO} 4$ & $\begin{array}{l}\text { Increased dynamisms in the trade, tourism } \\
\text { and manufacturing sectors }\end{array}$ & $\begin{array}{l}\text { Trade and Tourism growth rate increased from 1.3- } \\
1.5 \% \text { in } 2002 \text { to } 8.7-9.6 \% \text { in } 2007\end{array}$ & $\begin{array}{l}\text { National Accounts (CBS,CBK, KTB, } \\
\text { Catering Levy Trustees (CLT)) }\end{array}$ & $\mathrm{I}-16$ & A.3 \\
\hline DO5 & Universal Primary Education & $\begin{array}{l}\text { Increase primary school gross enrollment rate from } \\
90 \% \text { to } 100 \% \text { by } 2005 \text { and net primary school } \\
\text { enrollment to close to } 100 \% \text { by } 2015 \text { (MDG3); } \\
\text { reduce gender disparities in access to primary and } \\
\text { seconday education (MDG 4) }\end{array}$ & $\begin{array}{l}\text { School census (MoE), KDHS (CBS), } \\
\text { WMS (CBS) }\end{array}$ & $\mathrm{I}-18$ & B.1 \\
\hline \multirow[t]{3}{*}{ DO6 } & Expanded basic health services & $\begin{array}{l}\text { Reduce under } 5 \text { child mortality from } 114 \text { per } 1,000 \text { to } \\
100 \text { per } 1,000 \text { by } 2008 \text { (MDG5) }\end{array}$ & $\begin{array}{l}\text { KDHS (CBS), health facilities data } \\
(\mathrm{MoH}), \text { Census reports, Registrar of } \\
\text { Births and Deaths }\end{array}$ & $\mathrm{I}-18$ & B.1 \\
\hline & & $\begin{array}{l}\text { Reduce maternal mortality rate from } 590 \text { per } 100,000 \\
\text { to } 450 \text { per } 100,000 \text { by } 2008 \text { (MDG6) }\end{array}$ & $\begin{array}{l}\text { Health facilities data }(\mathrm{MoH}) \text {, Census } \\
\text { reports, Registrar of Births and Deaths }\end{array}$ & & \\
\hline & & $\begin{array}{l}\text { Reduce malaria morbidity (currently at } 30 \% \text { ) by } 10 \% \\
\text { annually in } 2003-2008 \text { (MDG8) }\end{array}$ & HIS of MoH & & \\
\hline DO7 & Halted and reduced HIV/AIDS spread & $\begin{array}{l}\text { Reduce HIV/AIDS prevalence by } 10 \% \text { annual in } \\
2003-2005 \text { among the youth age } 15-25 \text { (MDG7) }\end{array}$ & $\begin{array}{l}\text { Sentinel Surveillance (NASCOP-MoH); } \\
\text { KDHS (CBS) }\end{array}$ & $\mathrm{I}-18$ & B.1 \\
\hline DO8 & $\begin{array}{l}\text { Strengthened employment creation and } \\
\text { productivity }\end{array}$ & Half a million jobs created annually in 2003-2006 & $\begin{array}{l}\text { Labor force Survey (CBS), Jua Kali } \\
\text { associations records }\end{array}$ & $\mathrm{I}-21$ & B.2 \\
\hline$\overline{D O 9}$ & Increased agricultural productivity & $\begin{array}{l}\text { Value of agricultural exports rises by } 3 \% \text { per year } \\
\text { during 2003-06 }\end{array}$ & $\begin{array}{l}\text { Annual National Accounts/ Economic } \\
\text { survey data (Central Bureau of Statistics) }\end{array}$ & $\mathrm{I}-22$ & B.3 \\
\hline DO10 & Protected the environment & Hectage of forestry remaining and reclaimed (MDG9) & MoA, KWS, MLS & $\mathrm{I}-22$ & B.3 \\
\hline \multirow[t]{2}{*}{ DO11 } & Improved conditions of rural poor & $\begin{array}{l}\text { Coverage for rural water increased to } 60 \% \text { by } 2006 \\
\text { (MDG 10) }\end{array}$ & $\begin{array}{l}\text { Ministry of water resources, KLSS and } \\
\text { census (CBS) }\end{array}$ & $\mathrm{I}-26$ & B.4 \\
\hline & & $\begin{array}{l}\text { Proportion of rural population with access to secure } \\
\text { tenure expanded (MDG 11) }\end{array}$ & Ministry of Land and Settlements & & \\
\hline \multirow[t]{2}{*}{ DO12 } & Improved conditions of urban poor & $\begin{array}{l}\text { Coverage for urban water and sanitation services } \\
\text { increased by } 2 \% \text { per year from } 73 \% \text { to } 83 \% \text { and } 64 \% \\
\text { to } 74 \% \text { respectively (MDG } 10-11 \text { ). }\end{array}$ & $\begin{array}{l}\text { Surveys by MoW with relevant NGOs, } \\
\text { annual reports from water services } \\
\text { providers. }\end{array}$ & I-26 & B.4 \\
\hline & & $\begin{array}{l}\text { Proportion of urban population with access to secure } \\
\text { tenure expanded (MDG 11) }\end{array}$ & Ministry of Land and Settlements & & \\
\hline DO13 & Strengthened public safety, law and order & $\begin{array}{l}\text { Number of criminal offences reduced from } 75,352 \text { in } \\
2001 \text { to } 65,000 \text { in } 2006\end{array}$ & $\begin{array}{l}\text { Criminal Investigation Department, } \\
\text { Statistical Abstract (CBS) }\end{array}$ & $\mathrm{I}-29$ & C.1 \\
\hline DO14 & Improved public administration systems & $\begin{array}{l}\text { Wage bill reduced to below } 8.5 \% \text { of GDP and } \\
\text { programmatic budget implemented }\end{array}$ & & $\mathrm{I}-31$ & C. 2 \\
\hline$\overline{D O 15}$ & $\begin{array}{l}\text { Established adequate monitoring and } \\
\text { evaluation mechanisms }\end{array}$ & $\begin{array}{l}\text { Monitoring and evaluation system in place provides } \\
\text { timely feedback into budget process and yearly } \\
\text { progress reports }\end{array}$ & & $\mathrm{I}-33$ & C.3 \\
\hline
\end{tabular}




\begin{tabular}{|c|c|c|c|c|}
\hline Log & jical Framework Matrix for Ker & conomic Recovery Strategy for & Wealth and Employmen & it Generation (ERS) \\
\hline PA] & RT A.1: ECONOMIC GROWT & croeconomic Framework and $\mathrm{Fi}$ & inancial Sector Reforms & \\
\hline Narr & rative & Indicators & M\&E & Assumptions/Risks \\
\hline & & from ....to....bv(date) & data source and responsibility & \\
\hline Obje & ective & & & \\
\hline & Economic Growth & $\begin{array}{l}\text { GDP growth rate increases from } 1.2 \% \text { in } \\
2002 / 03 \text { to } 1.9 \% \text { in } 2003 / 04 \text { to } 3.1 \% \text { in } \\
2004 / 05 \text { and to } 4.5 \% \text { by } 2006 / 07\end{array}$ & Annual Economic Survey (CBS) & \\
\hline Deve & lopment outcomes & & & \\
\hline & & & & \\
\hline 1 & Macroeconomic stability and financial s & velopment & & \\
\hline D) & \begin{tabular}{|l|l|} 
Sustainable fiscal framework & \\
\end{tabular} & $\begin{array}{l}\text { Stock of Domestic Debt (net, end of } \\
\text { period) reduced from } 25.1 \% \text { of GDP in } \\
2002 / 03 \text { to } 17.7 \% \text { by } 2006 / 07\end{array}$ & $\begin{array}{l}\text { CBS and Treasury, CBK, } \\
\text { Quarterly. }\end{array}$ & \begin{tabular}{|l|} 
Availability of concessional \\
financing, no unanticipated govt \\
borrowing
\end{tabular} \\
\hline V & & $\begin{array}{l}\text { NPV of external debt (end period) kept } \\
\text { below } 24 \% \text { of GDP by } 2006 / 07\end{array}$ & & $\begin{array}{l}\text { shortfalls, emergency spending } \\
\text { higher }\end{array}$ \\
\hline 5 & & $\begin{array}{l}\text { Overall fiscal deficit (including grants) } \\
\text { reduced to } 3.3 \% \text { of GDP by 2006/07 }\end{array}$ & $\begin{array}{l}\text { Quarterly Budget Review } \\
\text { (Treasury) }\end{array}$ & \begin{tabular}{|l|} 
contingencies, exchange rate \\
stability, Rapid economic growth \\
strong fiscal consolidation at the \\
beginning of the period,
\end{tabular} \\
\hline ivil & $\begin{array}{l}\text { Increase in official foreign exchange } \\
\text { reserves }\end{array}$ & $\begin{array}{l}\text { Gross international reserve coverage in } \\
\text { months of next year imports (end of } \\
\text { period) to increase from } 2.9 \text { in } 2002 / 03 \text { to } \\
5 \text { in } 2006 / 07\end{array}$ & CBK & $\begin{array}{l}\text { Stable money supply growth and } \\
\text { exchange rate }\end{array}$ \\
\hline 5 & $\begin{array}{l}\text { Improved environment for private saving } \\
\text { and investment }\end{array}$ & $\begin{array}{l}\text { Private Savings increases from } 11 \% \text { of } \\
\text { GDP in } 2002 \text { to } 15 \% \text { of GDP by } 2005 / 06 \text {. }\end{array}$ & CBS and CBK, Annual report. & \begin{tabular}{|l|} 
Tax burden does not rise or falls \\
in relation to GDP, financial \\
intermediation improves.
\end{tabular} \\
\hline $\begin{array}{l}\square \\
0) \\
(0) \\
\square\end{array}$ & & $\begin{array}{l}\text { Gross Investment rises from } 14.5 \% \text { of } \\
\text { GDP in 2002/03 to } 24.9 \% \text { of GDP in } \\
2005 / 06\end{array}$ & CBS and CBK, Annual report & $\begin{array}{l}\text { Private investment response to } \\
\text { improved business climate, lowe } \\
\text { corruption and "smarter } \\
\text { regulation", judicial /business } \\
\text { dispute arbitration, better } \\
\text { infrastructure, lower cost and } \\
\text { better availability of credit and } \\
\text { share capital . Privatisation of } \\
\text { commercial activities }\end{array}$ \\
\hline C & $\begin{array}{l}\text { Low stable and market determined } \\
\text { interest rates }\end{array}$ & $\begin{array}{l}\text { Average Deposit Rates increase and } \\
\text { Lending Rates decline }\end{array}$ & CBK (monthly) & $\begin{array}{l}\text { Banking system responds to } \\
\text { monetary policy signals . }\end{array}$ \\
\hline (0) & & & & $\begin{array}{l}\text { Competition for deposits. } \\
\text { Deposit insurance. }\end{array}$ \\
\hline N19 & Low and stable inflation & Rate of inflation below $5 \%$ anuually & CBS Monthly CPI Reports & $\begin{array}{l}\text { Weather, exchange rate stability, } \\
\text { stable petroleum prices }\end{array}$ \\
\hline 8 & $\begin{array}{l}\text { Prudent, effective and accountable } \\
\text { management of public resources, and } \\
\text { restructuring in favor of discretionary } \\
\text { priority spending (development, } \\
\text { operations and maintenance and the poor) }\end{array}$ & $\begin{array}{l}\text { Reduced budget share of non-discretionar } \\
\text { and non-priority spending }\end{array}$ & $\begin{array}{l}\text { Quarterly budget review } \\
\text { (treasury) }\end{array}$ & \\
\hline & $\begin{array}{l}\text { Stable and effectively regulated financial } \\
\text { sector }\end{array}$ & $\begin{array}{l}100 \% \text { reports from Commercial Banks } \\
\text { submitted to Central Bank on time in } \\
\text { accordance with Central Bank Act by } 200\end{array}$ & $\begin{array}{l}\text { CBK, CBS Economic Survey; } \\
\text { Parliamentary Accounts and } \\
\text { O6nvestment Committees' Reports }\end{array}$ & $\begin{array}{l}\text { No political interference in } \\
\text { management of financial } \\
\text { institutions }\end{array}$ \\
\hline & & $\begin{array}{l}\text { Stock of non-performing loans reduced by } \\
\text { one third duirng 2003-2006 }\end{array}$ & yMonthly Central Bank Reports & Stable legislative environment \\
\hline Outp & puts & & & \\
\hline & & & & \\
\hline 1 & Macroeconomic stability and financials & forms & & \\
\hline 1.1 & Macroeconomic Framework & & & \\
\hline & Fiscal Policy & & & \\
\hline & $\begin{array}{l}\text { Achievement of more sustainable fiscal } \\
\text { position }\end{array}$ & $\begin{array}{l}\text { Overall fiscal deficit (including grants) } \\
\text { decreases from } 3.6 \% \text { of GDP in } 2002 / 03 \\
\text { to } 3.3 \% \text { in } 2006 / 07\end{array}$ & $\begin{array}{l}\text { MoF, Quarterly Budget Review, } \\
\text { Central Bank }\end{array}$ & $\begin{array}{l}\text { No shocks negatively impact the } \\
\text { economic growth forecast }\end{array}$ \\
\hline & Monetary policy & & & \\
\hline
\end{tabular}




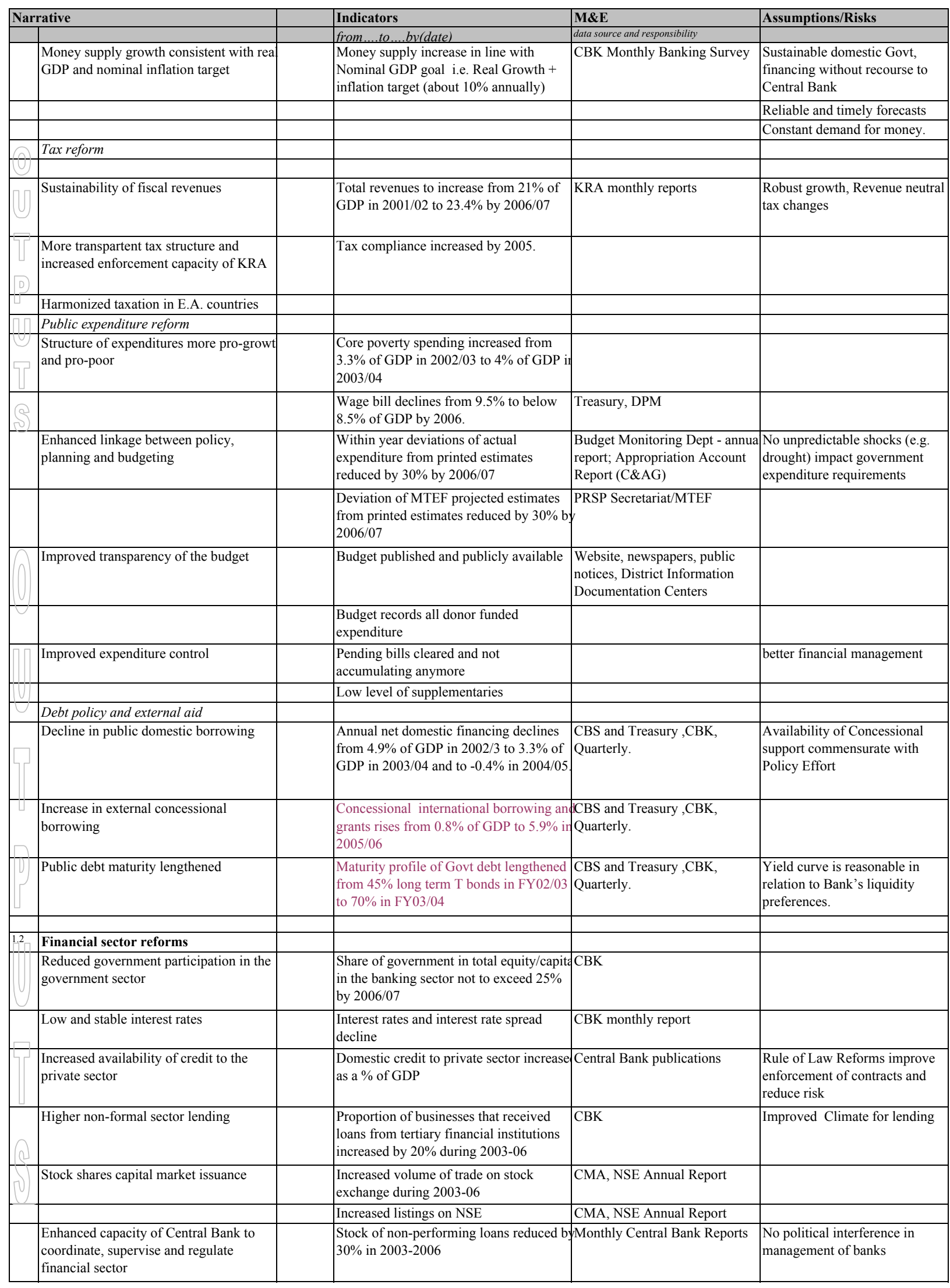




\begin{tabular}{|c|c|c|c|}
\hline Narrative & Indicators & M\&E & Assumptions/Risks \\
\hline & from ....to ....bv(date) & data source and responsibility & \\
\hline Strengthen confidence in financial sector & $\begin{array}{l}\text { Deposits in commercial banks increased } \\
\text { as a \% of GDP in 2003-2006 }\end{array}$ & Central Bank publications & \\
\hline & $\begin{array}{l}\text { Loan to reserve ratio increased during } \\
2003-06\end{array}$ & & \\
\hline & $\begin{array}{l}\text { Entreprise managers report greater } \\
\text { confidence }\end{array}$ & $\begin{array}{l}\text { Quarterly Business Expectation } \\
\text { Enquiry (CBS), Business surveys } \\
\text { (KMAP-KREP, others) }\end{array}$ & \\
\hline $\begin{array}{l}\text { Undertake actions to allow first tranche } \\
\text { release of proposed Financial Sector } \\
\text { Adjustment Credit by May 2004: }\end{array}$ & $\begin{array}{l}\text { 1. Adoption by the Government of a } \\
\text { financial sector reform strategy. }\end{array}$ & & \\
\hline & $\begin{array}{l}\text { Adoption and publication by the } \\
\text { Government of a restructuring and } \\
\text { privatization policy for the state- } \\
\text { influenced banking sector acceptable to } \\
\text { the Bank and providing the MoF with the } \\
\text { authority required to secure the full } \\
\text { cooperation of all parastatal bodies. }\end{array}$ & & \\
\hline & $\begin{array}{l}\text { 3. Adoption and publication by the } \\
\text { Government of a policy on the resolution } \\
\text { of NPA's carved out of state-influenced } \\
\text { banks (as a component of the policy on th } \\
\text { restructuring and privatization of state- } \\
\text { influenced banks described above) which } \\
\text { calls for the utilization of the private } \\
\text { sector to work out these assets either } \\
\text { under contract to the state or by means of } \\
\text { transparent auctions of NPA's to the } \\
\text { private sector. }\end{array}$ & & \\
\hline & $\begin{array}{l}\text { 4. Bank Restructuring \& Privatization } \\
\text { Unit to be adequately funded and staffed, } \\
\text { including consultants, and operating in a } \\
\text { manner satisfactory to the Bank. }\end{array}$ & & \\
\hline & $\begin{array}{l}\text { 5. KCB to comply with all regulatory } \\
\text { capital requirements. All state-nominated } \\
\text { board members to be replaced with } \\
\text { independent professional directors. } \\
\text { Tender for private sector investor(s) to } \\
\text { purchase the state's shares to be launched. }\end{array}$ & & \\
\hline & $\begin{array}{l}\text { 6. NBK: All state-nominated board } \\
\text { members to be replaced with independent } \\
\text { professional directors. Adoption and } \\
\text { implementation by NBK of a short term } \\
\text { restructuring plan and credit policies and } \\
\text { procedures satisfactory to the Bank. } \\
\text { Recapitalization of NBK to not less than } \\
2 \% \text { CAR and compliance with regulatory } \\
\text { minimums for liquidity. }\end{array}$ & & \\
\hline & $\begin{array}{l}\text { 7. Consolidated: Sale of all state- } \\
\text { influenced shares to private sector } \\
\text { investor(s). Either: (a) withdrawal of } \\
\text { IDB's banking license; or, (b) sale of all } \\
\text { state-influenced shares in IDB to either } \\
\text { multi/bi-lateral investors or private } \\
\text { investors. }\end{array}$ & & \\
\hline
\end{tabular}




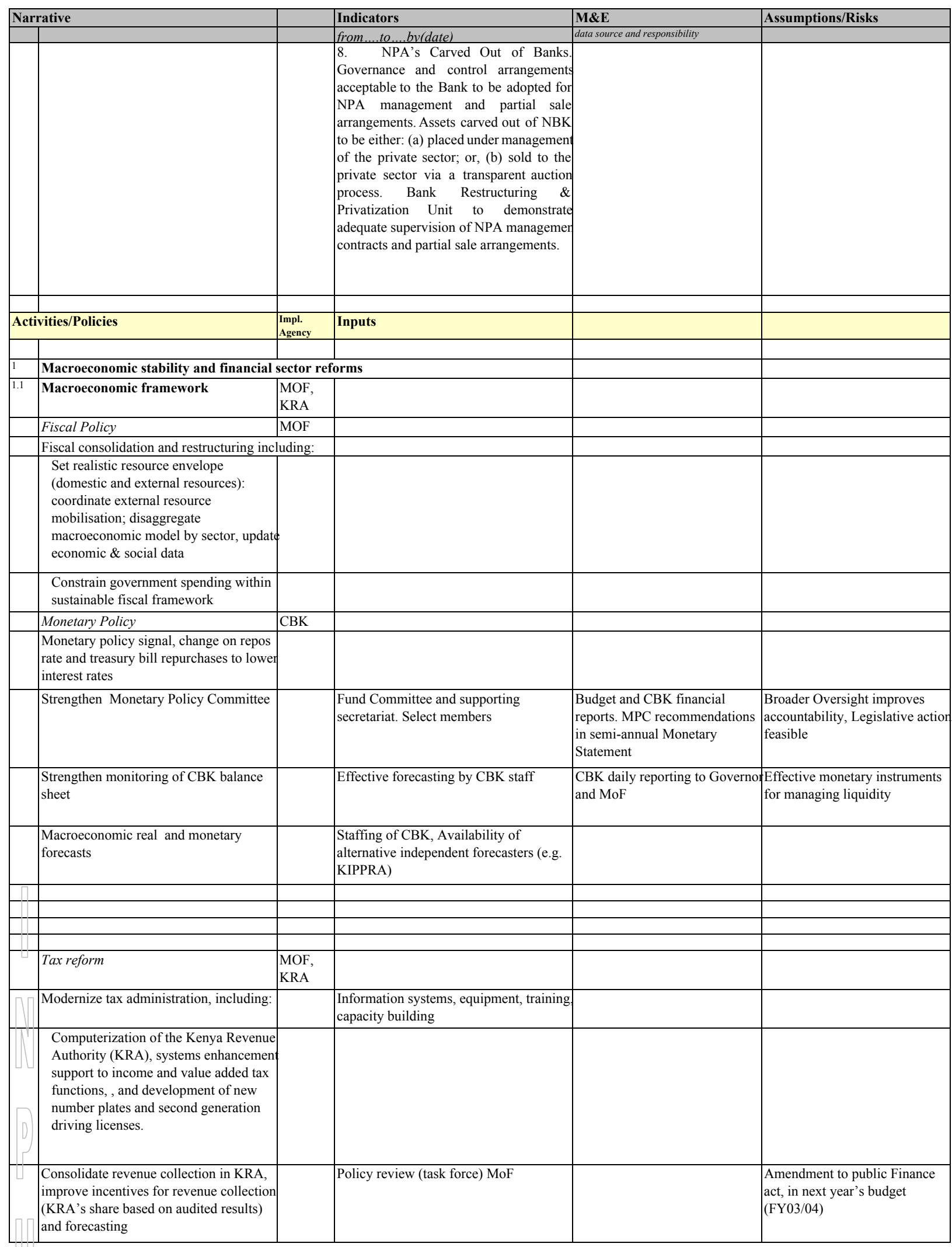




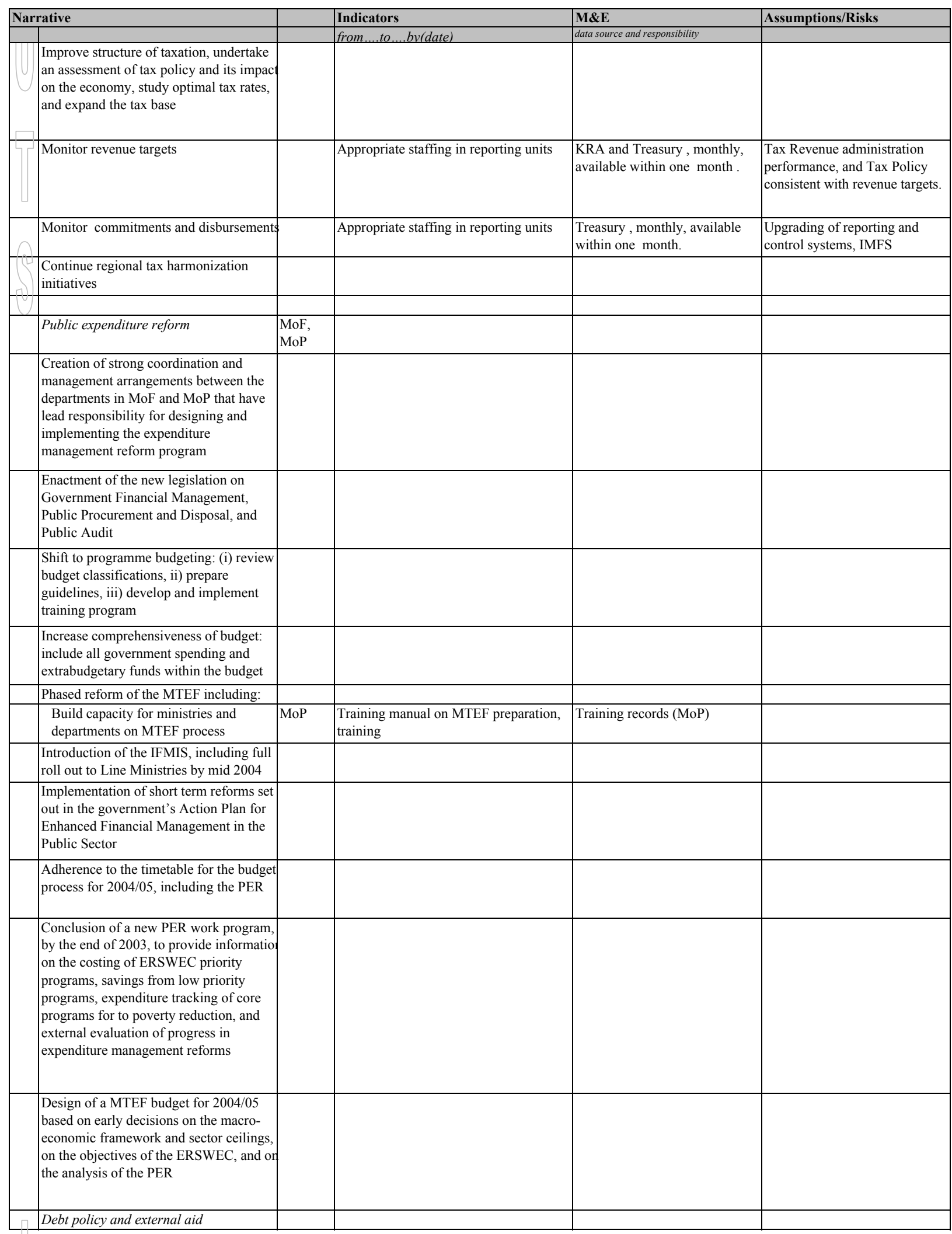




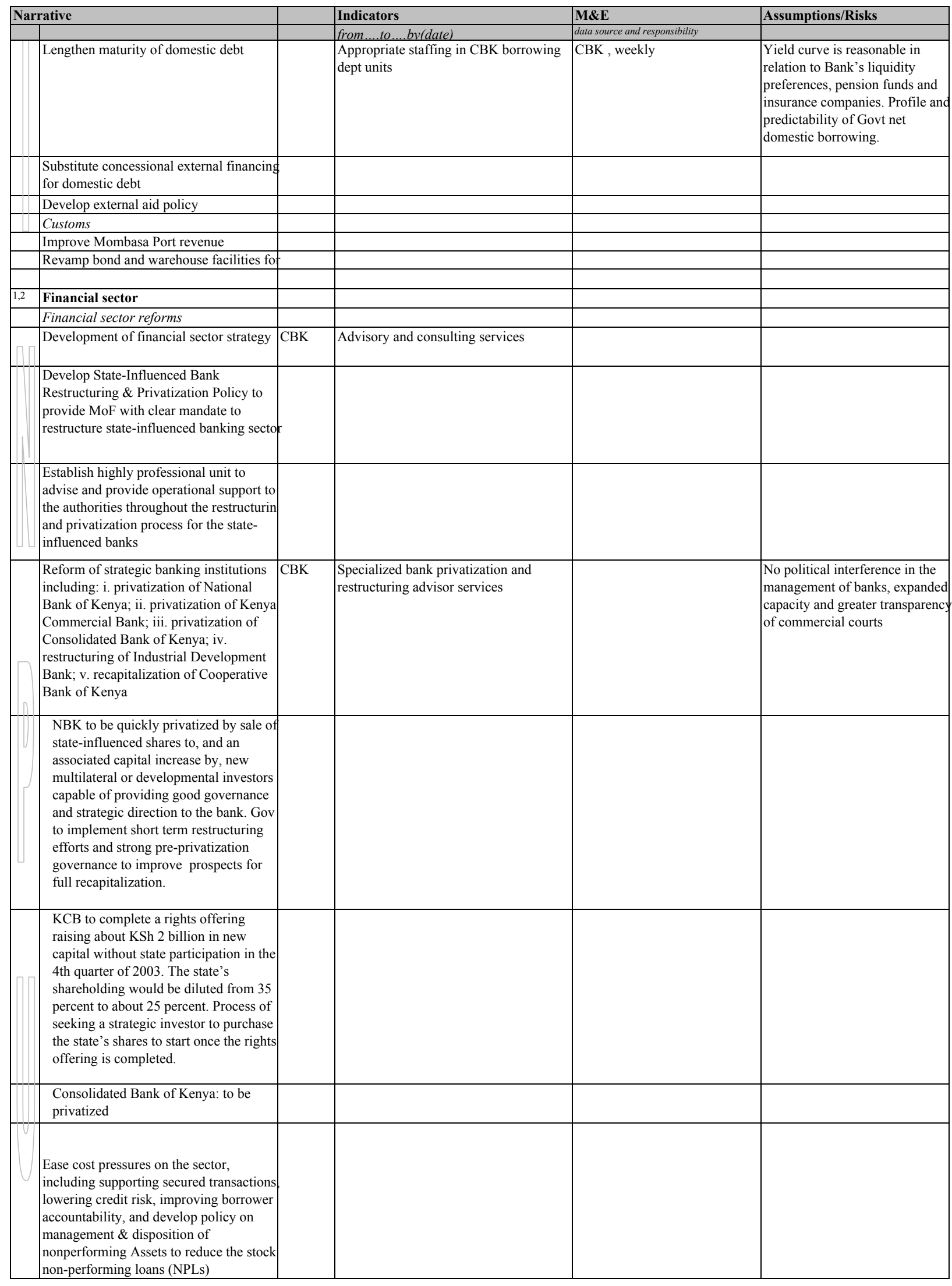




\begin{tabular}{|c|c|c|c|c|c|}
\hline \multicolumn{2}{|c|}{ Narrative } & & \multirow{2}{*}{$\begin{array}{l}\text { Indicators } \\
\text { from ....to ....bv(date) } \\
\end{array}$} & \multirow{2}{*}{\begin{tabular}{|l|}
$\mathbf{M} \& \mathbf{E}$ \\
data source and responsibility \\
\end{tabular}} & \multirow[t]{2}{*}{ Assumptions/Risks } \\
\hline & & & & & \\
\hline \multicolumn{6}{|c|}{$\begin{array}{l}\text { The CBK to undertake, with strong } \\
\text { technical support, a comprehensive } \\
\text { diagnostic of the condition of the small } \\
\text { and medium sized banks (excluding NBK } \\
\text { Consolidated and IDB) to ascertain their } \\
\text { true condition and implement enforcemen } \\
\text { actions to resolve any banks which are } \\
\text { undercapitalized before the end of } 2004 \text {. }\end{array}$} \\
\hline ए & $\begin{array}{l}\text { Establish credit reference bureau and } \\
\text { other measures to improve credit } \\
\text { evaluation }\end{array}$ & CBK & & & \\
\hline & $\begin{array}{l}\text { Strengthen DPF to enhance depositors } \\
\text { protection including: i. new DPF Act; ii. } \\
\text { Capacity building in workouts and } \\
\text { workout management techniques; iii. } \\
\text { Liquidation of distressed small banks }\end{array}$ & & $\begin{array}{l}\text { Legal advice to draft new DPF Act, } \\
\text { staffing and training, operational support }\end{array}$ & & \\
\hline & $\begin{array}{l}\text { Strengthen judicial infrastructure for } \\
\text { resolution of commercial disputes and } \\
\text { insolvencies, and computerize registries }\end{array}$ & & & & \\
\hline & Microfinance & & & & \\
\hline & Enact Micro Finance Institutions Act & & & & \\
\hline & Continue MicroSafe-Africa program & & Research services & & \\
\hline & $\begin{array}{l}\text { Build institutional capacity to deliver } \\
\text { services to the poor }\end{array}$ & & & & \\
\hline & Capital Markets & & & & \\
\hline O & Complete Central Depository System & & & & \\
\hline & $\begin{array}{l}\text { Strengthen disclosure rules and their } \\
\text { enforcement }\end{array}$ & & & & \\
\hline & $\begin{array}{l}\text { Introduce second tier market to allow } \\
\text { medium firm access to capital markets }\end{array}$ & & & & \\
\hline & Insurance markets & & & & \\
\hline & $\begin{array}{l}\text { Develop comprehensive strategy for } \\
\text { insurance services development }\end{array}$ & & & & \\
\hline & Financial sector regulation & & & & \\
\hline & Enforce Central Bank Act & CBK & & $\begin{array}{l}\text { Reports on status of commercial } \\
\text { banks (CBK) }\end{array}$ & \\
\hline & $\begin{array}{l}\text { Transfer banking system licensing, } \\
\text { regulatory and disciplinary authority from } \\
\text { the Ministry of Finance to the CBK }\end{array}$ & & & & \\
\hline & $\begin{array}{l}\text { Strengthen supervisory and enforcement } \\
\text { capacity of CBK }\end{array}$ & CBK & Training, cap building & & \\
\hline & \begin{tabular}{|l} 
Tighten provisioning regulations to \\
conform to international best practice
\end{tabular} & & & & \\
\hline & $\begin{array}{l}\text { Remove regulation on banks charges and } \\
\text { commissions }\end{array}$ & & & & \\
\hline & $\begin{array}{l}\text { Implement anti-money laundering } \\
\text { legislation. }\end{array}$ & & & & \\
\hline & $\begin{array}{l}\begin{array}{l}\text { Develop a modern national payments } \\
\text { system }\end{array} \\
\end{array}$ & & & & \\
\hline & Build CBK Research Department capacity & & & & \\
\hline & $\begin{array}{l}\text { Survey level of access to financial service } \\
\text { by household and businesses }\end{array}$ & & Surveying services & & \\
\hline & $\begin{array}{l}\text { Map outlets of formal and semi-formal } \\
\text { finance institutions to determine } \\
\text { geographical distribution of services }\end{array}$ & & Surveying services & & \\
\hline
\end{tabular}




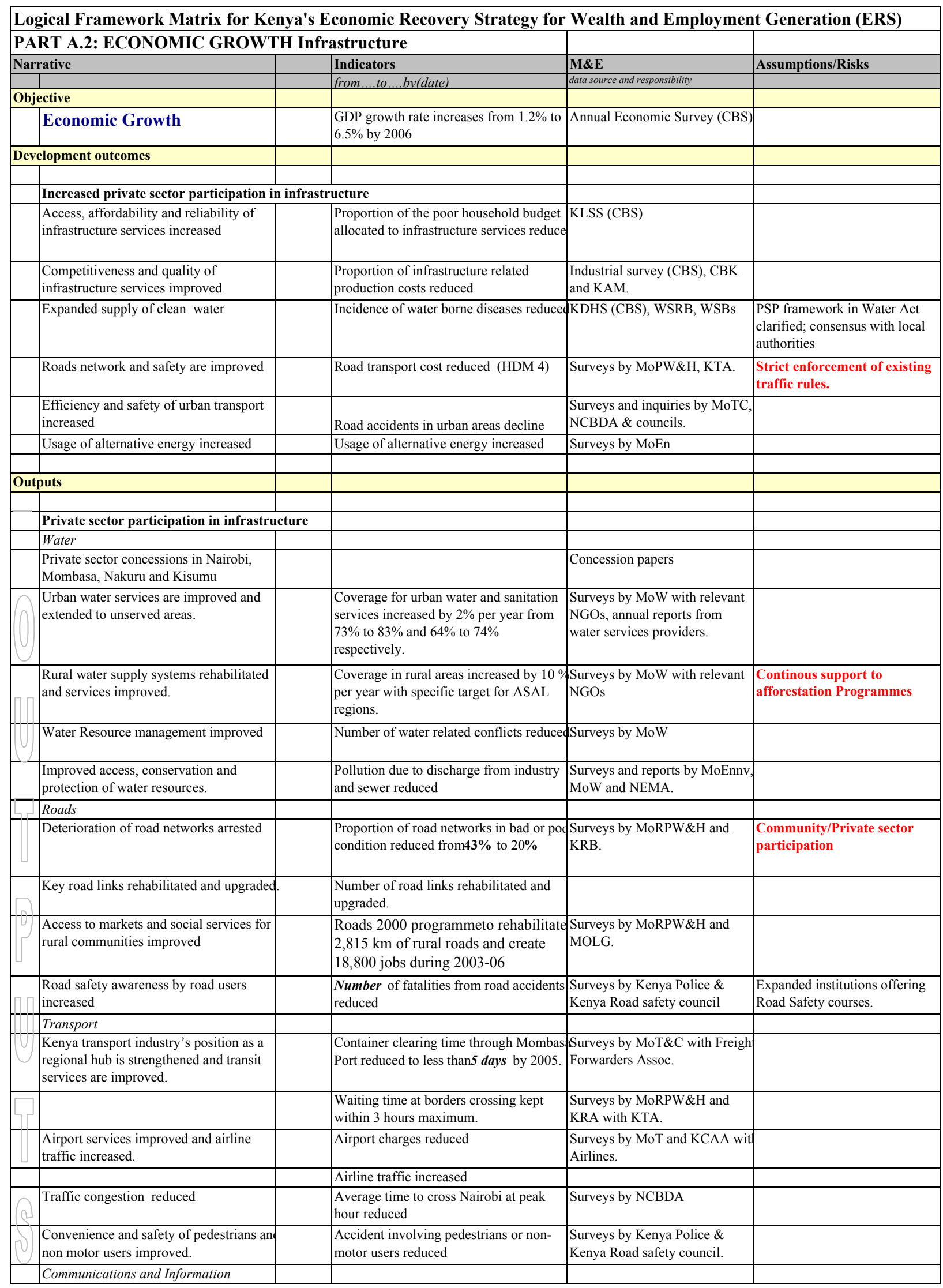




\begin{tabular}{|c|c|c|c|c|c|}
\hline \multicolumn{2}{|c|}{ Narrative } & & \multirow{2}{*}{\begin{tabular}{|l} 
Indicators \\
from ....to ....bv (date) \\
\end{tabular}} & \multirow{2}{*}{\begin{tabular}{|l|} 
M\&E \\
data source and responsibility \\
\end{tabular}} & \multirow[t]{2}{*}{ Assumptions/Risks } \\
\hline & & & & & \\
\hline & Telkom privatized & & $\begin{array}{l}\text { International public bidding undertaken b. } \\
\text { June } 2005\end{array}$ & & $\begin{array}{l}\text { Modalities of restructuring } \\
\text { and privatisation agreed upon. }\end{array}$ \\
\hline & Telecom and ICT services expanded & & $\begin{array}{l}\text { Tele-density increased from } 3 \text { per } 100 \text { to } \\
\text { per } \mathbf{1 0 0} \text { by } 2006 .\end{array}$ & $\begin{array}{l}\text { Surveys by MoTC and CCK, } \\
\text { and reports of service providers }\end{array}$ & \\
\hline & & & $\begin{array}{l}\text { Internet user increased from currentl.2 } \\
\text { per } 1000\end{array}$ & & \\
\hline & IT Policy in place & & & & Concensus on IT Policy \\
\hline & Significant expansion of e-Government & & $\begin{array}{l}\text { Number of internet connection in } \\
\text { government institutions rise from to by } \\
2006 .\end{array}$ & & \\
\hline & Energy & & & & \\
\hline & $\begin{array}{l}\text { Reliable energy services available at lowe } \\
\text { costs improved. }\end{array}$ & & $\begin{array}{l}\text { Power tariff reduced from 5\% to 3\% by } \\
\text { 2006. Electricity rates reduced }\end{array}$ & Published tariff by KPLC & \\
\hline 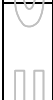 & $\begin{array}{l}\text { Access to electricity by rural communitie } \$ \\
\text { is increased. }\end{array}$ & & $\begin{array}{l}\text { Increase access by } 1 \% \text { per annum for the } \\
\text { rural population from } 3.8 \% \text { to } 8 \% \text { by } \\
2006 \text {. }\end{array}$ & Surveys by MoEn \& KPLC. & $\begin{array}{l}\text { Ability to subsidise rural } \\
\text { communities }\end{array}$ \\
\hline U & $\begin{array}{l}\text { Increased usage of alternative energy } \\
\text { technologies }\end{array}$ & & $\begin{array}{l}\text { Installed capacity of solar energy } \\
\text { increased by } 10 \% \text { per year. }\end{array}$ & $\begin{array}{l}\text { Surveys by MoEn with relevant } \\
\text { industry }\end{array}$ & \\
\hline & Increase in LPG consumption & & $\begin{array}{l}\text { LPG consumption increased from } 32,000 \\
\mathrm{~m} / \text { tons to } 50,000 \mathrm{~m} / \text { tons by } 2006 .\end{array}$ & Surveys by MoEn & \\
\hline & \multicolumn{2}{|l|}{ Privatization and competitive framework } & & & \\
\hline & \begin{tabular}{|l|l|} 
Privatization Bill \\
\end{tabular} & & Privatization Bill approved by 2003 & Kenya Gazette & \\
\hline 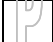 & Competitive framework & & Competitive framework in place by 2005 & & \\
\hline & \multicolumn{2}{|l|}{ Regulatory framework for infrastructure } & & & \\
\hline & $\begin{array}{l}\text { Improved regulatory frameworks for all } \\
\text { infrastructure sectors }\end{array}$ & & $\begin{array}{l}\text { Regulatory framework in place for all } \\
\text { infrastructure sectors by } 2006\end{array}$ & $\begin{array}{l}\text { Surveys by CBK and all } \\
\text { Infrastructure Ministries }\end{array}$ & $\begin{array}{l}\text { Privatization bill passed and } \\
\text { private sector is interested }\end{array}$ \\
\hline 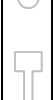 & & & & & $\begin{array}{l}\text { Key infrastructure restructuring } \\
\text { and reforms are completed (i.e. } \\
\text { water, energy, roads, telecom) }\end{array}$ \\
\hline \multirow[t]{5}{*}{ 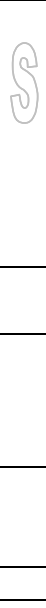 } & $\begin{array}{l}\text { Established water sector boards (WSBs), } \\
\text { water resources management authority } \\
\text { (WRMA) and water services regulatory } \\
\text { board (WSRB) as stipulated in the Water } \\
\text { Act } 2002\end{array}$ & & $\begin{array}{l}\text { Strategies for Integrated WRM and WSS } \\
\text { gazetted under Water Act } 2002\end{array}$ & Surveys by MoW and CBK & $\begin{array}{l}\text { Private sector interest; legal and } \\
\text { regulatory framework and } \\
\text { arrangements for PSP in Water } \\
\text { Act clarified; consensus and } \\
\text { linkages with other water using } \\
\text { agencies and with local } \\
\text { authorities; clarity on } \\
\text { decentralization of functions }\end{array}$ \\
\hline & & & $\begin{array}{l}\text { WSRB issuing licenses to Water Services } \\
\text { Boards (WSB) - } 2004\end{array}$ & $\begin{array}{l}\text { Annual reports of the WRMA } \\
\text { and WSRB }\end{array}$ & \\
\hline & & & $\begin{array}{l}\text { WRMA operational including, local level } \\
\text { institutions (basin/catchment and } \\
\text { community level) in priority areas - } 2005\end{array}$ & & \\
\hline & $\begin{array}{l}\text { Better trained staff of the existing } \\
\text { regulatory agencies such as ERB and CCK }\end{array}$ & & $\begin{array}{l}\text { Number of regulatory agency staff trained } \\
\text { by } 2006\end{array}$ & $\begin{array}{l}\text { Surveys by ERB and CCK with } \\
\text { MoT and MoE }\end{array}$ & $\begin{array}{l}\text { Relevant training institutions are } \\
\text { identified }\end{array}$ \\
\hline & Implementation of Maritime laws & & Number of offenders arrested & & Finalisation of regional laws. \\
\hline \multicolumn{2}{|c|}{ Activities/Policies } & \begin{tabular}{|l|} 
Impl. \\
Agency
\end{tabular} & Inputs & & \\
\hline \multicolumn{3}{|c|}{ Private sector participation in infrastructure } & & & \\
\hline & \begin{tabular}{|l|l} 
Water and Sanitation & 1 \\
\end{tabular} & MoW & & & \\
\hline & $\begin{array}{l}\text { Government carries out structural reform } \\
\text { to put WSS services on an autonomous } \\
\text { basis and introduce PSP in Nairobi and } \\
\text { Mombasa \& Coastal region, Nakuru and } \\
\text { Kisumu }\end{array}$ & & $\begin{array}{l}\text { WSB lincenses, contract with service } \\
\text { providers }\end{array}$ & & $\begin{array}{l}\text { Privatization bill approved by } \\
\text { Parliament; consensus built with } \\
\text { local authorities; clarification of } \\
\text { Water Act's framework for PSP }\end{array}$ \\
\hline
\end{tabular}




\begin{tabular}{|c|c|c|c|c|c|}
\hline \multicolumn{2}{|c|}{ Narrative } & & \multirow{2}{*}{$\begin{array}{l}\text { Indicators } \\
\text { from ....to ....bv(date) } \\
\end{array}$} & \multirow{2}{*}{\begin{tabular}{|l|} 
M\&E \\
data source and responsibility \\
\end{tabular}} & \multirow[t]{2}{*}{ Assumptions/Risks } \\
\hline & & & & & \\
\hline & $\begin{array}{l}\text { Government mobilizes investment to } \\
\text { support rehabilitation and services } \\
\text { extension }\end{array}$ & & $\begin{array}{l}\text { Number of rehabilited facilities by private } \\
\text { sector. }\end{array}$ & & $\begin{array}{l}\text { Strong private sector interested } \\
\text { in involvement in operational } \\
\text { management and investment in } \\
\text { water services. }\end{array}$ \\
\hline & $\begin{array}{l}\text { Government in partnership with CBOs } \\
\text { and private providers carries out program } \\
\text { to extend WSS services to urban poor and } \\
\text { rural communities }\end{array}$ & & Number of urban poor participating & & $\begin{array}{l}\text { Development Partners willing to } \\
\text { support Kenya Water sector at } \\
\text { the appropriate scale. }\end{array}$ \\
\hline & & & Number resettled & & $\begin{array}{l}\text { Land tenure issues in informal } \\
\text { urban settlements are addressed. }\end{array}$ \\
\hline & $\begin{array}{l}\text { Implement the water act } 2002 \text { including } \\
\text { the establishment of Water Service } \\
\text { Boards, the Water Services Regulatory } \\
\text { Board and the Water Services Trust Fund }\end{array}$ & & Operational Boards & & $\begin{array}{l}\text { Political will and coordination } \\
\text { among relevant ministries }\end{array}$ \\
\hline & Roads & MRPW & & & \\
\hline U & $\begin{array}{l}\text { Gov to complete institutional reforms of } \\
\text { road management under Kenya Roads } \\
\text { Board. }\end{array}$ & & & & $\begin{array}{l}\text { Reform of road management and } \\
\text { financing sustained. }\end{array}$ \\
\hline & $\begin{array}{l}\text { Govt to develop and launch multi-year } \\
\text { integrated roads program }\end{array}$ & & & & $\begin{array}{l}\text { Support from Kenya } \\
\text { Development Partners } \\
\text { mobilized. }\end{array}$ \\
\hline & $\begin{array}{l}\text { Govt to concession the Mombasa-Malaba } \\
\text { Corridor and sections of the Norther } \\
\text { Corridor to the private sector }\end{array}$ & & $\begin{array}{l}\text { Concessioning } 1,208 \mathrm{~km} \text { of trunk road } \\
\text { during 2004-07 }\end{array}$ & Concession documents & $\begin{array}{l}\text { New Road Bill passed, Private } \\
\text { sector interested. }\end{array}$ \\
\hline & $\begin{array}{l}\text { Gov to launch National road safety } \\
\text { campaign involving stakeholders i.e. } \\
\text { drivers, police, insurance companies. }\end{array}$ & & Gazettement & & Relevant stakeholders mobilized \\
\hline & Gov to enforce axle load limits & & Number of cases & & \\
\hline U & $\begin{array}{l}\text { Gov to decongest major urban areas by } \\
\text { building by-pass road for Nairobi and } \\
\text { Mombasa }\end{array}$ & & & Implementation reports & \\
\hline & $\begin{array}{l}\text { Gov to implement Northern Corridor } \\
\text { Improvements (Lanet-Timboroa, } \\
\text { Machakos Turn Off- Sultan Hamud, Mau } \\
\text { Summit- Awasi) }\end{array}$ & & Kms constructed & Implementation reports & \\
\hline & $\begin{array}{l}\text { Government pursues improvement and } \\
\text { rehabilitation of rural roads and bridges } \\
\text { under Road } 2000 \text { program }\end{array}$ & & Kms completed & Implementation reports & $\begin{array}{l}\text { Sustainability of the roads } 2000 \\
\text { program and training of small } \\
\text { scale contractors continues. }\end{array}$ \\
\hline & Transport & MRPW & & & \\
\hline & \begin{tabular}{|l|l|} 
Prepare National Transport Policy \\
\end{tabular} & & Publication of document & & \\
\hline & $\begin{array}{l}\text { Implement institutional strengthening pla } \\
\text { for the transport sector }\end{array}$ & & & & \\
\hline A & $\begin{array}{l}\text { Gov. sector operators and stakeholders to } \\
\text { speed up full implementation of transport } \\
\text { facilitation programs agreed within EAC } \\
\text { and COMESA }\end{array}$ & & Operationalisation of program & & $\begin{array}{l}\text { Political will and commitment to } \\
\text { regional collaboration within the } \\
\text { EAC and COMESA. }\end{array}$ \\
\hline 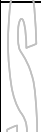 & $\begin{array}{l}\text { Gov. to finalize the concessioning and } \\
\text { rehabilitation of Kenya Railways (KR) in } \\
\text { coordination with EAC railways and } \\
\text { development partners; }\end{array}$ & & & & $\begin{array}{l}\text { Privatization bill approved by } \\
\text { Parliament }\end{array}$ \\
\hline V & $\begin{array}{l}\text { and divest from Gulf Marine service on } \\
\text { Lake Victoria }\end{array}$ & & & & $\begin{array}{l}\text { Coordination with Uganda and } \\
\text { possibly Tanzania }\end{array}$ \\
\hline
\end{tabular}




\begin{tabular}{|c|c|c|c|c|c|}
\hline \multicolumn{2}{|c|}{ Narrative } & & \multirow{2}{*}{\begin{tabular}{|l|} 
Indicators \\
from ....to ....bv(date $)$ \\
\end{tabular}} & \multirow{2}{*}{\begin{tabular}{|l|}
$\mathbf{M} \& \mathbf{E}$ \\
data source and responsibility \\
\end{tabular}} & \multirow[t]{2}{*}{ Assumptions/Risks } \\
\hline & & & & & \\
\hline & $\begin{array}{l}\text { Convert Mombasa Port to a landlord port } \\
\text { by June 2005. KPA to maintain regulator } \\
\text { functions and port ownership. Private } \\
\text { sector to operate the port infrastructure } \\
\text { (channels, locks, berths) plus the port } \\
\text { superstructure (surfacing, sheds, and } \\
\text { fences). Private operators will provide } \\
\text { user services in a competitive } \\
\text { environment (pilotage, towage, berthing, } \\
\text { supplies, cargo handling, storage, repair, } \\
\text { security), and manage the container } \\
\text { terminal by means of a long-term } \\
\text { concession. }\end{array}$ & & $\begin{array}{l}\text { Number of private sector operatos } \\
\text { engaged }\end{array}$ & & $\begin{array}{l}\text { Capacity to address social } \\
\text { retrenchment plan }\end{array}$ \\
\hline & $\begin{array}{l}\text { Gov to address airport security, and obtain } \\
\text { Federal Aviation Authority security } \\
\text { grading class } 1 \text {. Activities: refurbishing of } \\
\text { airport facilities, investment in security } \\
\text { equipment (e.g. security procedures, } \\
\text { fencing, terminal reorganization, security } \\
\text { equipment, and training of security } \\
\text { inspectors) and reduce airport charges }\end{array}$ & & & & Private sector interested \\
\hline & $\begin{array}{l}\text { Implement KCAA reform to meet ICAO } \\
\text { standards }\end{array}$ & & $\begin{array}{l}\text { Training, cinsulting services and } \\
\text { equipment }\end{array}$ & & \\
\hline 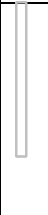 & $\begin{array}{l}\text { Improve handling capacity including } \\
\text { upgrade capacity of regional airports, } \\
\text { privatize commercial non-regulatory } \\
\text { services at airport, explore potential for } \\
\text { Private Sector participation in building } \\
\text { new terminals and handling non security } \\
\text { services }\end{array}$ & & & & \\
\hline & $\begin{array}{l}\text { Gov and municipalities to develop and } \\
\text { implement traffic management and urban } \\
\text { mobility plans i.e. bus-stops, non- } \\
\text { motorized traffic. }\end{array}$ & & & & $\begin{array}{l}\text { Revival of traffic lights in major } \\
\text { urban centers }\end{array}$ \\
\hline 75 & $\begin{array}{l}\text { Gov and NCC to plan and implement } \\
\text { urban bypass to divert transit traffic from } \\
\text { city center (e.g. Donyo Kundu). }\end{array}$ & & Kms constructed & & \\
\hline D) & Communications and Information & $\begin{array}{l}\text { MoTC, } \\
\text { TelKom, } \\
\text { CCK }\end{array}$ & & & \\
\hline r & $\begin{array}{l}\text { Gov to complete liberalization of Telecon } \\
\text { and ICT services }\end{array}$ & & $\begin{array}{l}\text { Publication of ICT policy \& licencing } \\
\text { of } 2 \text { nd telccommunications provid }\end{array}$ & ICT policy. & $\begin{array}{l}\text { Private sector interested in } \\
\text { investment }\end{array}$ \\
\hline & Privatize TelKom & & & & \\
\hline & $\begin{array}{l}\text { License 3rd mobile provider and 3-4 } \\
\text { gateway service providers }\end{array}$ & & & & \\
\hline & $\begin{array}{l}\text { Gov. to accelerate programs to modernize } \\
\text { regional and global systems linkages. }\end{array}$ & & & & $\begin{array}{l}\text { Regional collaboration } \\
\text { framework sustained. }\end{array}$ \\
\hline$\checkmark$ & $\begin{array}{l}\text { Develop policy, legislative and financial } \\
\text { framework for ICT growth }\end{array}$ & & ICT policy operational & Implementation report & \\
\hline 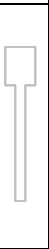 & $\begin{array}{l}\text { Promote ICT adoption and skill } \\
\text { development, including a country- } \\
\text { wide ICT awareness campaign; and } \\
\text { implement an ICT skill enhancement } \\
\text { campaign integrating ICT in school } \\
\text { curricula as training, teaching aid and } \\
\text { learning materials }\end{array}$ & & Introduction of Curriculum in schools & Implementation report & \\
\hline & \begin{tabular}{|l|l|} 
Promote e-Government \\
\end{tabular} & & Adoption of e-Government strategy & Implementation report & \\
\hline$A$ & Install infrastructure & & & & \\
\hline (1) & $\begin{array}{l}\text { Implement Gov information technology } \\
\text { investment management framework } \\
\text { (GITIM) }\end{array}$ & & Installation of Structured cabling & Implementation report & \\
\hline - & Implement e-government services & & Completion of connectivity & Implementation report & \\
\hline
\end{tabular}




\begin{tabular}{|c|c|c|c|c|}
\hline \multirow[t]{2}{*}{ Narrative } & & \multirow{2}{*}{$\begin{array}{l}\text { Indicators } \\
\text { from to by(date) }\end{array}$} & \multirow{2}{*}{\begin{tabular}{|l|}
$\mathbf{M} \& \mathbf{E}$ \\
data source and responsibility \\
\end{tabular}} & \multirow[t]{2}{*}{ Assumptions/Risks } \\
\hline & & & & \\
\hline Energy & MoEn & & & \\
\hline $\begin{array}{l}\text { Gov. to develop Energy Sector } \\
\text { Development Strategy, including power, } \\
\text { petroleum and rural energy subsectors, to } \\
\text { turn around the sector's operational and } \\
\text { financial performance }\end{array}$ & & $\begin{array}{l}\text { Energy Sector Development Strategy } \\
\text { approved by Feb } 2004\end{array}$ & & Strong political will to reform \\
\hline $\begin{array}{l}\text { Strengthen regulatory functions of the } \\
\text { Electricity Regulatory Board (ERB) and } \\
\text { review existing tariff regime and } \\
\text { methodology for setting tariffs }\end{array}$ & & & & \\
\hline \begin{tabular}{|l|} 
Implement policy on privatization of \\
KPLC to enhance KPLC performance on \\
commercial operations, transmission, \\
distribution, and collection of receivables \\
with special emphasis on reinforcement \\
and rehabilitation of distribution systems \\
in Nairobi and Mombasa
\end{tabular} & & & & \\
\hline $\begin{array}{l}\text { Implement policy on privatization of } \\
\text { KenGen to improve management } \\
\text { performance }\end{array}$ & & & & \\
\hline $\begin{array}{l}\text { Implement rural energy program includin } \\
\text { electrification, wind energy, minihydros, } \\
\text { solar PV }\end{array}$ & & & & $\begin{array}{l}\text { Public and private funding of } \\
\text { investments, maintenance and } \\
\text { operation costs ensured . }\end{array}$ \\
\hline $\begin{array}{l}\text { Gov to complete and implement the LPG } \\
\text { study including standardizing valves }\end{array}$ & & & & \\
\hline $\begin{array}{l}\text { Gov to explore opportunities and expedite } \\
\text { negotiations for increased power imports } \\
\text { and other links to regional power pools } \\
\text { (e.g. South Africa, Uganda, Tanzania) }\end{array}$ & & & & \\
\hline $\begin{array}{l}\text { Gov to implement Least Cost } \\
\text { Development Plan for power developmen } \\
\text { including: }\end{array}$ & & & & \\
\hline $\begin{array}{l}\text { Implement Olkaria II Geothermal Powe } \\
\text { Plant }\end{array}$ & KenGen & & & \\
\hline Implement other power projects & $\begin{array}{l}\text { IPPs, } \\
\text { MoEn, } \\
\text { KenGen }\end{array}$ & & & \\
\hline $\begin{array}{l}\text { Convert existing gas turbines in } \\
\text { Mombasa }\end{array}$ & & & & \\
\hline Complete Sondu-Miriu power project & $\begin{array}{l}\text { MoEn, } \\
\text { KenGen }\end{array}$ & & & \\
\hline \begin{tabular}{|l|} 
Develop clear policy and institutional \\
arrangements on the exploitation of \\
geothermal resources, and development of \\
private/public partnerships
\end{tabular} & & & & \\
\hline Decide on the future of the KPRL refinery & MoEn & & & \\
\hline Privatization and competitive framewor & & & & \\
\hline $\begin{array}{l}\text { Prepare Privatization bill to provide a } \\
\text { legal framework for the privatization } \\
\text { process }\end{array}$ & & & & \\
\hline $\begin{array}{l}\text { Enact and reform laws relating to } \\
\text { competition including reforming the } \\
\text { Monopolies and Price Control Act }\end{array}$ & & & & \\
\hline $\begin{array}{l}\text { Enact Investment Code and establish } \\
\text { Investment Authority (a one-stop } \\
\text { investment office) }\end{array}$ & $\begin{array}{l}\text { MTI, } \\
\text { IPC }\end{array}$ & & & \\
\hline Develop Investment Road Map & & & & \\
\hline $\begin{array}{l}\text { Carry out comprehensive review of } \\
\text { licensing arrangements }\end{array}$ & $\begin{array}{l}\text { MTI, } \\
\text { IPC, } \\
\text { MoF, } \\
\text { AG }\end{array}$ & & & \\
\hline
\end{tabular}




\begin{tabular}{|c|c|c|c|c|}
\hline \multicolumn{2}{|c|}{ Narrative } & \multirow{2}{*}{$\begin{array}{l}\text { Indicators } \\
\text { from ....to ....bv(date) }\end{array}$} & \multirow{2}{*}{\begin{tabular}{|l|}
$\mathbf{M} \& \mathbf{E}$ \\
data source and responsibility \\
\end{tabular}} & \multirow[t]{2}{*}{ Assumptions/Risks } \\
\hline & & & & \\
\hline & \multicolumn{2}{|l|}{ Regulatory framework for infrastructure } & & \\
\hline & $\begin{array}{l}\text { Establish an inter-ministerial committee } \\
\text { to review, with the aim to increase PSP in } \\
\text { public utilities, the regulatory } \\
\text { arrangements of key sectors (telecom/IT, } \\
\text { water, energy, roads and transport) }\end{array}$ & $\begin{array}{l}\text { The Cabinet forms the committee and } \\
\text { makes Ksh.... available to facilitate its } \\
\text { tasks }\end{array}$ & & \\
\hline D) & $\begin{array}{l}\text { Assess the feasibility and options for } \\
\text { setting up an independent multi-sector } \\
\text { regulatory agency for all infrastructure } \\
\text { sectors as a way of boosting private secto } \\
\text { participation and reducing regulatory cost }\end{array}$ & & & \\
\hline$\square$ & $\begin{array}{l}\text { Implement the newly passed Water Act } \\
2002 \text { as a way of spearheading PSP in the } \\
\text { water sector }\end{array}$ & $\begin{array}{l}\text { Technical assistance from development } \\
\text { partners to set up the WSBs, WRMA and } \\
\text { WSRB }\end{array}$ & & \\
\hline$(5)$ & $\begin{array}{l}\text { Strengthen the capacities of the existing } \\
\text { regulatory agencies (ERB and CCK) to } \\
\text { boost private sector confidence in the } \\
\text { telecommunications and energy sectors } \\
\text { and better monitoring of performance } \\
\text { targets in these sectors. }\end{array}$ & $\begin{array}{l}\text { Technical assistance from development } \\
\text { partners to complement the training } \\
\text { budget of ERB and CCK }\end{array}$ & & \\
\hline & $\begin{array}{l}\text { Energy: Amend Electric Power and } \\
\text { Petroleum Acts to allow for appropriate } \\
\text { regulation }\end{array}$ & New power act & & \\
\hline
\end{tabular}




\begin{tabular}{|c|c|c|c|c|c|}
\hline \multicolumn{6}{|c|}{ Logical Framework Matrix for Kenya's Economic Recovery Strategy for Wealth and Employment Generation (ERS) } \\
\hline \multicolumn{6}{|c|}{\begin{tabular}{|l|l|l|} 
PART A.3: ECONOMIC GROWTH Productive Sectors & &
\end{tabular}} \\
\hline \multicolumn{2}{|r|}{\begin{tabular}{|l|l|} 
Narrative \\
\end{tabular}} & & \multirow{2}{*}{\begin{tabular}{|l|} 
Indicators \\
from ....to....by (date) \\
\end{tabular}} & \multirow{2}{*}{\begin{tabular}{|l|} 
M\&E \\
data source and responsibility
\end{tabular}} & \multirow[t]{2}{*}{ Assumptions/Risks } \\
\hline & & & & & \\
\hline \multicolumn{6}{|c|}{ Objective } \\
\hline & Economic Growth & & $\begin{array}{l}\text { GDP growth rate increases from } 1.2 \% \text { to } \\
6.5 \% \text { by } 2006\end{array}$ & Annual Economic Survey (CBS) & \\
\hline \multicolumn{6}{|c|}{ Development outcomes } \\
\hline & & & & & \\
\hline \multicolumn{6}{|c|}{ Increased dynamisms in the tourism, trade, and industry } \\
\hline & $\begin{array}{l}\text { Increase contribution of Trade and } \\
\text { Tourism to the economy }\end{array}$ & & $\begin{array}{l}\text { Trade and Tourism growth rate increased } \\
\text { from } 1.3-1.5 \% \text { in } 2002 \text { to } 8.7-9.6 \% \text { in } \\
2007\end{array}$ & $\begin{array}{l}\text { National Accounts (CBS,CBK, } \\
\text { KTB, Catering Levy Trustees } \\
\text { (CLT)) }\end{array}$ & $\begin{array}{l}\text { Improved international and } \\
\text { domestic security }\end{array}$ \\
\hline & & & Sector generates 150,000 new jobs & Employment survey & $\begin{array}{l}\text { Strong world economic } \\
\text { conditions }\end{array}$ \\
\hline & & & $\begin{array}{l}\text { Tourist earnings double in 2003/04 from } \\
\text { KSh 24B in 2005/6 }\end{array}$ & National Accounts & Adequate capacity availability \\
\hline & & & $\begin{array}{l}\text { Number of tourist arrivals increase from } \\
0.8 \text { to } 1.5 \text { million by } 2003 / 04\end{array}$ & National Accounts & $\begin{array}{l}\text { New investments in tourist } \\
\text { infrastructure including airports }\end{array}$ \\
\hline & Increased revenues from tourism & & $\begin{array}{l}\text { Tourism levy receipts increased from } \\
\text { KShs } 400 \mathrm{~m} \text { to KShs } 1 \text { bn }\end{array}$ & $\mathrm{MoF}$ & Legislation \\
\hline & $\begin{array}{l}\text { Decreased dependency on traditional } \\
\text { agricultural exports }\end{array}$ & & $\begin{array}{l}\text { Share of agricultural exports in total } \\
\text { export earnings decline }\end{array}$ & National Accounts & $\begin{array}{l}\text { Increase in Agricultural } \\
\text { productivity }\end{array}$ \\
\hline & Increase cotton related exports & & Export of cotton products increases & National Accounts & $\begin{array}{l}\text { Continued liberatlisation in } \\
\text { World Trade }\end{array}$ \\
\hline \multicolumn{6}{|c|}{ Outputs } \\
\hline & & & & & \\
\hline 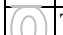 & Tourism, Trade and Industry & & & & \\
\hline U & Simplified Trade Legislation & & $\begin{array}{l}\text { \# of steps required for importing/exportin } \\
\text { goods and services reduced }\end{array}$ & MoT reports & $\begin{array}{l}\text { Labor market reforms in place; } \\
\text { infrastructure improved }\end{array}$ \\
\hline ए & Local Authority Trade Licensing revoked & & $\begin{array}{l}\text { Local Authority Trade Licensing revoked } \\
\text { by } 2004\end{array}$ & Gazette & \\
\hline D & New EPZs and MUBs established & & Number of scheduled zones increased & MoT reports & \\
\hline$\square$ & Investment related offices on line & & $\begin{array}{l}\text { Proportion of investment related offices } \\
\text { with internet connection }\end{array}$ & Implementation reports & \\
\hline-+ & Tourist Levy increased and base widened & & Tourist levy increased from $2 \%$ to $4 \%$ & $\begin{array}{l}\text { Levy Collection returns by } \\
\text { Trustees. }\end{array}$ & $\begin{array}{l}\text { Levy consistent with Macro } \\
\text { targets. }\end{array}$ \\
\hline \multicolumn{6}{|c|}{ - } \\
\hline @) & Tourism promotion campaigns & & $\begin{array}{l}\text { Media purchases; \# of tourist office in key } \\
\text { markets }\end{array}$ & Implementation reports & $\begin{array}{l}\text { Absence of negative travel } \\
\text { advisories }\end{array}$ \\
\hline & Tourist Police Force upgraded & & \begin{tabular}{|l|}
$\#$ of tourist police force trained and \\
reequipped
\end{tabular} & Police Deployment records & \\
\hline & $\begin{array}{l}\text { Improved information access to national } \\
\text { hotels and restaurants }\end{array}$ & & Information available on line & Website, web search & \\
\hline & Industrial Master Plan published & & IMP prepared by 2004 & Published document & \\
\hline & $\begin{array}{l}\text { Sessional Paper on Industrial } \\
\text { Transformation operationalized }\end{array}$ & & Stakeholder consultation & Implementation reports & \\
\hline & Sessional paper on MSE & & Sessional paper on MSEs issued in 2004 & Implementation reports & \\
\hline & Title deeds issues to Jua Kali Association $\$$ & & $\begin{array}{l}\text { No. of title deeds issued to Jua kali } \\
\text { Associations }\end{array}$ & & Absence of land disputes \\
\hline & Increased access to MSEs services & & $25 \%$ of MSEs access loans by 2006 & & Availability of loanable funds \\
\hline & & & $\begin{array}{l}25 \% \text { of MSEs with market outlets by } \\
2006\end{array}$ & & \\
\hline & & & $25 \%$ of MSEs trained by 2006 & & \\
\hline \multicolumn{2}{|c|}{ Activities/Policies } & Impl. & Inputs & & \\
\hline & Tourism & Agency & & & \\
\hline & $\begin{array}{l}\text { Develop and implement aggressive } \\
\text { marketing of Kenya as major tourist } \\
\text { destination }\end{array}$ & MT & 2 million tourists per annum & Arrival data & $\begin{array}{l}\text { International security, } \\
\text { international cooperation on } \\
\text { terrorism }\end{array}$ \\
\hline & $\begin{array}{l}\text { Exploit film industry and sports tourism } \\
\text { niches }\end{array}$ & & New films being shot in Kenya & Filming licences sought. & \\
\hline & Encourage domestic tourism & & Increase in \%tage of domestic tourists & $\begin{array}{l}\text { Increase share of Domestic for } \\
19 \% \text { to } 50 \%\end{array}$ & $\begin{array}{l}\text { Increase local disposable } \\
\text { incomes. }\end{array}$ \\
\hline
\end{tabular}




\begin{tabular}{|c|c|c|c|c|c|}
\hline \multicolumn{2}{|c|}{ Narrative } & & \multirow{2}{*}{\begin{tabular}{|l} 
Indicators \\
from ....to ....bv(date)
\end{tabular}} & \multirow{2}{*}{\begin{tabular}{|l|}
$\mathbf{M \& E}$ \\
data source and responsibility \\
\end{tabular}} & \multirow[t]{2}{*}{ Assumptions/Risks } \\
\hline & & & & & \\
\hline & $\begin{array}{l}\text { Publish classification of Hotels and } \\
\text { Restaurants on the gazette and on the web }\end{array}$ & & Web services & $\begin{array}{l}\text { Gazette MTI staff, web } \\
\text { publication by KTB }\end{array}$ & $\begin{array}{l}\text { Completion of classification } \\
\text { exercise by MOTI }\end{array}$ \\
\hline & $\begin{array}{l}\text { Upgrade and reorganize Tourist Police } \\
\text { Force (see Governance) }\end{array}$ & & $\begin{array}{l}\text { Training, personnel emoluments, } \\
\text { equipment, and logistics }\end{array}$ & Patrol Coverage & \\
\hline & Review structure of taxation in the sector & & Number of taxes reviewed & $\begin{array}{l}\text { Reduction in the overall price } \\
\text { structure in establishments }\end{array}$ & \\
\hline & $\begin{array}{l}\text { Foster community-based eco-tourism and } \\
\text { community-based wildlife conservation; } \\
\text { provide guidance, access to credit and } \\
\text { incentives to SMEs; and review structure } \\
\text { of park tariffs in favor of less-visited } \\
\text { parks. Restructure KTDC. }\end{array}$ & & Support 80 new SME's & No. of Jobs created & Robust growth in Tourism \\
\hline & Trade \& Investment & & & & \\
\hline & $\begin{array}{l}\text { Complete sessional paper on Trade Policy } \\
\text { by } 2004\end{array}$ & MTI & Stakeholder consultation & Document published & \\
\hline$\sqrt{1}$ & $\begin{array}{l}\text { Review licensing agreements, provide } \\
\text { market information to Kenyan } \\
\text { manufacturers, support the private sector } \\
\text { in identifying new markets, improve } \\
\text { quality of Kenyan goods, reduce non- } \\
\text { commercial risks, organize export trade } \\
\text { fairs, and exploit AGOA. }\end{array}$ & & Improved market access & $\begin{array}{l}\% \text { increase in trade and } \\
\text { investment volume }\end{array}$ & \\
\hline 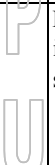 & $\begin{array}{l}\text { Develop and export development strategy } \\
\text { including review of export promotion } \\
\text { schemes }\end{array}$ & $\begin{array}{l}\text { MTI, } \\
\text { EPC, } \\
\text { IPC, } \\
\text { EPZA, } \\
\text { MoF }\end{array}$ & Comprehensive export strategy estblished & Incresed exports & \\
\hline$\varnothing$ & Review trade related legislation & MTI & Inter-Ministerial Committees & & \\
\hline & Revoke local authority trade licencing & MTI & Reduction in transaction costs & Official Gazette Notice & $\begin{array}{l}\text { Political will; Equivalent } \\
\text { compensation through transfers } \\
\text { (LATF) }\end{array}$ \\
\hline$(2)$ & $\begin{array}{l}\text { Establish export processing villages for } \\
\text { smallholder producers; and expand EPZs } \\
\text { and Manufacturing Under Bonds (MUBs } \\
\text { for export promotion }\end{array}$ & $\begin{array}{l}\text { MLG, } \\
\text { MTI, } \\
\text { MoF, } \\
\text { MoL }\end{array}$ & Increased EPZ\&MUB investments & $\begin{array}{l}\text { Increased volume of processed } \\
\text { exports. }\end{array}$ & $\begin{array}{l}\text { Suitability of the designated } \\
\text { sites; }\end{array}$ \\
\hline & $\begin{array}{l}\text { Implement investment code and reduce } \\
\text { the number of regulations and step } \\
\text { required for investing in the country }\end{array}$ & & Reduction in transaction costs & Reduction in no of regulations & \\
\hline & Industry & & & & \\
\hline$\sqrt{1}$ & $\begin{array}{l}\text { Implement comprehensive strategy to } \\
\text { remove barriers to investment and lower } \\
\text { the cost of doing business, including } \\
\text { further liberalizing trade, deepening the } \\
\text { financial market, enhancing infrastructure, } \\
\text { improving security, facilitating use of } \\
\text { technology licenses, reviewing } \\
\text { mechanisms for wage determination, and } \\
\text { improving access to quality training. }\end{array}$ & MTI & Improvement of the business environmen & New investments registered & \\
\hline & $\begin{array}{l}\text { Benchmark key industries (sugar, textile) } \\
\text { to international competitors }\end{array}$ & $\begin{array}{l}\text { MIT, } \\
\text { EPC } \\
\text { IPC, } \\
\text { MoF }\end{array}$ & Improvement in competiveness & Benchmarking schedule & \\
\hline & $\begin{array}{l}\text { Promote backward linkage in Textile } \\
\text { Industry to exploit AGOA }\end{array}$ & & $\begin{array}{l}\text { Cotton production extension services, } \\
\text { credit to ginneries, industrial promotion } \\
\text { campaigns }\end{array}$ & Increased production of cotton & \\
\hline$(5)$ & $\begin{array}{l}\text { Operationalize Sessional Paper on } \\
\text { Industrial Transformation through the } \\
\text { Industrial Masterplan }\end{array}$ & & $\begin{array}{l}\text { Consultancy services, Inter-ministerial } \\
\text { and private sector consultations }\end{array}$ & Implementation schedule. & \\
\hline & Micro, Small and Medium Enterprises & & & & \\
\hline & $\begin{array}{l}\text { Finalize sessional paper on MSEs with } \\
\text { focus on employment creation }\end{array}$ & & & & \\
\hline
\end{tabular}




\begin{tabular}{|c|c|c|c|}
\hline Narrative & Indicators & M\&E & Assumptions/Risks \\
\hline & from....to....bv(date) & data source and responsibility & \\
\hline $\begin{array}{l}\text { Strengthen financial institutions } \\
\text { providing small business credit, such } \\
\text { as the Kenya Industrial Estates (KIE), }\end{array}$ & & & \\
\hline $\begin{array}{l}\text { Develop market for training small } \\
\text { business entrepreneurs, possibly } \\
\text { through demand incentive schemes, }\end{array}$ & & & \\
\hline $\begin{array}{|lr|}\text { Strengthen vertical linkages within } \\
\text { the industrial sector and } \\
\text { subcontracting arrangements built in } \\
\text { privatization processes, }\end{array}$ & $\begin{array}{l}\text { Identification of institutions, } \\
\text { dissemination \& sensitization }\end{array}$ & & \\
\hline \multicolumn{2}{|c|}{ Provide information on technology and marketing } & & \\
\hline $\begin{array}{l}\text { Enhance provision of infrastructure and } \\
\text { finance for the Jua Kali sector }\end{array}$ & $\begin{array}{l}\text { Rehabilitation of } 653 \text { sheds \& } \\
\text { construction of } 14 \text { more sheds while } \\
\text { putting in place a micro-financing policy } \\
\text { by end of } 2004 .\end{array}$ & & \\
\hline
\end{tabular}




\begin{tabular}{|c|c|c|c|c|c|}
\hline & gical Framework Matrix for Ke & enya's & conomic Recovery Strategy for & Wealth and Employmen & it Generation (ERS) \\
\hline & RT B.1: EQUITY AND POVE & RTY & EDUCTION Human Resource D & Development: Education, & Health and HIV/AIDS \\
\hline Nar & rative & & Indicators & M\&E & Assumptions/Risks \\
\hline & & & from ....to....bv(date) & data source and responsibility & \\
\hline Obj & ective & & & & \\
\hline & Poverty Reduction & & $\begin{array}{l}\text { Reduce proportion of the people below th } \\
\text { absolute poverty lines (Kenya and \$1PPP) } \\
\text { by } 10 \% \text { by } 2006 \text { from } 57 \% \text { in } 1997 \\
\text { (MDG1) }\end{array}$ & $\begin{array}{l}\text { Kenya Living Standard Survey- } \\
\text { KLSS (CBS) (in design stage) }\end{array}$ & \\
\hline & & & $\begin{array}{l}\text { Reduce proportion of people living in } \\
\text { hunger by } 10 \% \text { by } 2006 \text { (MDG2) }\end{array}$ & MoA, WFP, FAO, KLSS & \\
\hline Dev & elopment Outcomes & & & & \\
\hline & & & & & \\
\hline$D$ & Education, Health and HIV/AIDS & & & & \\
\hline $\begin{array}{l} \\
\\
\\
\\
\\
\\
\end{array}$ & Universal primary education & & $\begin{array}{l}\text { Increase primary school gross enrollment } \\
\text { rate from } 90 \% \text { to } 100 \% \text { by } 2005 \text { and net } \\
\text { primary school enrollment from } 80 \% \text { to } \\
85 \% \text { by } 2007\end{array}$ & $\begin{array}{l}\text { School census (MoE), KDHS } \\
\text { (CBS), WMS (CBS) }\end{array}$ & $\begin{array}{l}\text { Guiding and counseling in } \\
\text { schools, teachers able to enforce } \\
\text { discipline without corporal } \\
\text { punishment, parent involvement } \\
\text { in child homework, nutrition } \\
\text { programs effective, children } \\
\text { health status improved }\end{array}$ \\
\hline$(0$ & & & $\begin{array}{l}\text { Reduce gender gap in access to primary } \\
\text { and seconday education (MDG 4) }\end{array}$ & $\begin{array}{l}\text { School census (MoE), KDHS } \\
\text { (CBS), WMS (CBS) }\end{array}$ & $\begin{array}{l}\text { The girl child will given } \\
\text { opportunities for education and } \\
\text { that cultural barrier will not } \\
\text { hinder them. }\end{array}$ \\
\hline $\mathbb{N}$ & & & $\begin{array}{l}\text { Transition rate from primary to secondary } \\
\text { from } 47 \% \text { to } 70 \% \text { by } 2005\end{array}$ & $\begin{array}{l}\text { School census (MoE), KDHS } \\
\text { (CBS), WMS (CBS) }\end{array}$ & $\begin{array}{l}\text { Physical facilities will be } \\
\text { renovated and expanded }\end{array}$ \\
\hline 5 & Improve access to basic health services & & $\begin{array}{l}\text { Reduce under } 5 \text { child mortality from } 114 \\
\text { per } 1,000 \text { to } 100 \text { per } 1,000 \text { by } 2008 \\
\text { (MDG5) }\end{array}$ & $\begin{array}{l}\text { KDHS (CBS), health facilities } \\
\text { data (MoH), Census reports, } \\
\text { Registrar of Births and Deaths }\end{array}$ & HIV prevalence declines \\
\hline 4 & & & $\begin{array}{l}\text { Reduce maternal mortality rate from } 590 \\
\text { per } 100,000 \text { to } 560 \text { per } 100,000 \text { by } 2008 \\
\text { (MDG6) }\end{array}$ & $\begin{array}{l}\text { Health facilities data }(\mathrm{MoH}) \\
\text { Census reports, Registrar of } \\
\text { Births and Deaths }\end{array}$ & $\begin{array}{l}\text { Distances to nearest facility } \\
\text { reduced, staff trained and equiped }\end{array}$ \\
\hline (0) & & & $\begin{array}{l}\text { Reduce malaria morbidity (currently at } \\
30 \% \text { ) by } 10 \% \text { annually in } 2003-2008 \\
\text { (MDG8) }\end{array}$ & $\mathrm{HIS}$ of $\mathrm{MoH}$ & \begin{tabular}{|l|} 
Distances to nearest facility \\
reduced, staff trained and equiped
\end{tabular} \\
\hline (U) & & & $\begin{array}{l}\text { Reduce the households out of pocket } \\
\text { financing of health from the current } 53 \% \\
\text { of the total health budget to } 45 \% \text { by } 2008 \text {. }\end{array}$ & $\begin{array}{l}\text { Household Expenditure Survey } \\
\text { (CBS), National Health Account } \\
\text { (MOH) }\end{array}$ & $\begin{array}{l}\text { NSHI established, GoK } \\
\text { tallocation to health increased }\end{array}$ \\
\hline $\begin{array}{c}-(9) \\
0 \\
\sqrt{1} \\
5 \\
5 \\
5 \\
\end{array}$ & Halted and reduced HIV/AIDS spread & & $\begin{array}{l}\text { Reduce HIV/AIDS prevalence to } 10 \% \text { by } \\
2006\end{array}$ & $\begin{array}{l}\text { Sentinel Surveillance (NASCOP } \\
\text { MoH); KDHS (CBS) }\end{array}$ & $\begin{array}{l}\text { Youth change their sexual } \\
\text { behavior (abstinence and safer } \\
\text { sex); religious organizations will } \\
\text { not actively oppose condom } \\
\text { programming; mitigation of socis } \\
\text { economic causes programs } \\
\text { effective; keeping girls in school }\end{array}$ \\
\hline Out & puts & & & & \\
\hline 8 & Education, Health and HIV/AIDS & & & & \\
\hline & Education & MoE & & & \\
\hline (4) & $\begin{array}{l}\text { Reduced costs of primary education to } \\
\text { families }\end{array}$ & & \begin{tabular}{|l|} 
Primary school fees eliminated by 2003, \\
70,000 poor children provided with \\
bursaries, and 150,000 more children fed \\
in school
\end{tabular} & MoE, Education NGOs & \begin{tabular}{|l|} 
parents from poor families will \\
allow their children to go school
\end{tabular} \\
\hline \begin{tabular}{|l|l|}
$D$ \\
5 \\
0
\end{tabular} & $\begin{array}{l}\text { Increased enrollment of girls, pastoralist, } \\
\text { street children, slum children }\end{array}$ & & $\begin{array}{l}\text { Primary school enrollment of pastoralist } \\
\text { increased from } 20 \text { to } 40 \% \text { by } 2006 \text {. No. of } \\
\text { street children in school increased. No. of } \\
\text { slum children in school }\end{array}$ & $\begin{array}{l}\text { School census (MoE), KDHS } \\
\text { (CBS), WMS (CBS) }\end{array}$ & $\begin{array}{l}\text { parents from poor families as } \\
\text { well those from pastoral } \\
\text { communities will allow their } \\
\text { children to go school }\end{array}$ \\
\hline & $\begin{array}{l}\text { Availability of learning and teaching } \\
\text { materials in primary school }\end{array}$ & & $\begin{array}{l}\text { Pupil/textbook ratio increased to } 3: 1 \text { in std } \\
1-5 \text { and to } 2: 1 \text { in std } 6-8 \text { by } 2004 \text {. }\end{array}$ & $\begin{array}{l}\text { dSchool records and MoE records } \\
\text { (MoE) }\end{array}$ & \\
\hline (a) & Additional classrooms & & 10,000 primary school classrooms built. & School mapping reports (MoE) & Funds are available \\
\hline- & $\begin{array}{l}\text { Strengthened education management } \\
\text { information system }\end{array}$ & & $\begin{array}{l}\text { Education management information } \\
\text { system in place in MoE and districts }\end{array}$ & & \\
\hline & Health & $\mathrm{MoH}$ & & & \\
\hline
\end{tabular}




\begin{tabular}{|c|c|c|c|c|c|}
\hline \multicolumn{2}{|c|}{ Narrative } & & \multirow{2}{*}{\begin{tabular}{|l|} 
Indicators \\
from ....to ....bv(date)
\end{tabular}} & \multirow{2}{*}{\begin{tabular}{|l|}
$\mathbf{M} \& \mathbf{E}$ \\
data source and responsibility \\
\end{tabular}} & \multirow[t]{2}{*}{ Assumptions/Risks } \\
\hline & & & & & \\
\hline & $\begin{array}{l}\text { Increased equity and affordability for low- } \\
\text { income patients }\end{array}$ & & $\begin{array}{l}\text { Increase budget allocation for rural health } \\
\text { centers and dispensaries from } 11 \% \text { to } 15 \% \\
\text { of } \mathrm{MoH} \text { budget by } 2005 \text {; and budget } \\
\text { allocations for drugs from } 12 \% \text { to } 16 \% \text { of } \\
\text { MoH budget by } 2006 \text {. }\end{array}$ & Budget estimates; PER & $\begin{array}{l}\text { Distances to nearest facility } \\
\text { reduced, staff trained and equiped }\end{array}$ \\
\hline & $\begin{array}{l}\text { Strategic Plan for National Social Health } \\
\text { Insurance }\end{array}$ & & $\begin{array}{l}\text { Sessional Paper on National Social Health } \\
\text { Insurance (NSHI) plan prepared by } 2004\end{array}$ & & \\
\hline & $\begin{array}{l}\text { Strengthen promotive and preventive } \\
\text { health }\end{array}$ & & $\begin{array}{l}\text { Increase proportion of children fully } \\
\text { immunized from } 74 \% \text { in } 2002 \text { to } 85 \% \text { in } \\
2008\end{array}$ & KDHS (CBS) & \\
\hline & & & $\begin{array}{l}\text { Contraceptive prevalence rate increases } \\
\text { from } 38 \% \text { to } 45 \% \text { in } 2008\end{array}$ & KDHS (CBS) & $\begin{array}{l}\text { Advocacy and counseling will } \\
\text { continue to be carried out }\end{array}$ \\
\hline-1 & & & $\begin{array}{l}\text { Increased proportion of mothers } \\
\text { delivering in health facilities from } 56 \% \text { to } \\
70 \% \text { in } 2008\end{array}$ & KDHS (CBS), HIS (MoH) & $\begin{array}{l}\text { Distances to nearest facility } \\
\text { reduced, staff trained and equipe }\end{array}$ \\
\hline$\square$ & & & $\begin{array}{l}\text { All HIV pregant mother receiving } \\
\text { Navirapine treatment by } 2008\end{array}$ & HIS $(\mathrm{MoH}), \mathrm{NASCOP}$ & $\begin{array}{l}\text { Supply and distribution of drugs } \\
\text { will be efficient }\end{array}$ \\
\hline$D$ & & & $\begin{array}{l}\text { Proportion of population in Western and } \\
\text { Coastal areas and of pregnant mothers } \\
\text { using ITNs from } 5 \% \text { to } 50 \% \text { by } 2008\end{array}$ & KDHS (CBS), HIS (MoH & $\begin{array}{l}\text { Supply and distribution of drugs } \\
\text { will be efficient }\end{array}$ \\
\hline r & & & $\begin{array}{l}\text { Guidelines for appointment of DHMBs } \\
\text { reviewed by 2003; all DHMBs and } \\
\text { DHMTs trined on management by } 2004\end{array}$ & Gazzette notice; $\mathrm{MoH}$ & \\
\hline+ & Increased budget allocations to health & & $\begin{array}{l}\text { Share of health expeditures increase from } \\
5.6 \text { to } 12 \% \text { of public budget }\end{array}$ & & \\
\hline$\overline{5}$ & HIV/AIDS & NACC & & & \\
\hline 1 & $\begin{array}{l}\text { New institutional and legal framework for } \\
\text { HIV/AIDS }\end{array}$ & & & Gazette, decrees & \\
\hline 3 & Strengthened HIV prevention & & $\begin{array}{l}\text { Condom usage increased as a } \% \text { of the } \\
\text { sexually active population }\end{array}$ & $\begin{array}{l}\text { BSS (NASCOP/CBS); KDHS } \\
\text { (CBS) }\end{array}$ & \\
\hline & & & $\begin{array}{l}\text { Several VCT centers established in } \\
\text { unattended areas by } 2004\end{array}$ & NASCOP data & \\
\hline & Expanded HIV treatment & & $\begin{array}{l}\text { Proportion of patients covered by ARV } \\
\text { increased by } 2005\end{array}$ & $\mathrm{MoH}$ & $\begin{array}{l}\text { ARVs will be available in } \\
\text { adequate numbers }\end{array}$ \\
\hline \multicolumn{2}{|c|}{ Activities/Policies } & $\begin{array}{l}\text { Implementin } \\
\text { g Agency }\end{array}$ & Inputs & & \\
\hline \multicolumn{6}{|c|}{ Education, Health and HIV/AIDS } \\
\hline & Education & MoE & & & \\
\hline \multicolumn{6}{|c|}{$\begin{array}{l}\text { Ensure equitable enrolment by targeting } \\
\text { disadvantaged areas and groups, including }\end{array}$} \\
\hline & Elimination of school levies & & School grants & Budget disbursement & Overcrowding, demoralized \\
\hline & $\begin{array}{l}\text { Introduction of alternative education } \\
\text { delivery methods (multi-shift, multi } \\
\text { grade, non formal) }\end{array}$ & & $\begin{array}{l}\text { Teacher training; hardship allowances; } \\
\text { training materials; alternative curricula; } \\
\text { school meals }\end{array}$ & $\begin{array}{l}\text { Training records, budget } \\
\text { disbursements; MoE records }\end{array}$ & \\
\hline \multicolumn{6}{|c|}{$\begin{array}{l}\text { Provision of bursaries to students from } \\
\text { poor families, particularly in ASALs }\end{array}$} \\
\hline & $\begin{array}{l}\text { Expand school feeding program by } \\
150,000 \text { students }\end{array}$ & & & & \\
\hline \multicolumn{6}{|c|}{$\begin{array}{l}\text { Improve quality and internal efficiency } \\
\text { through teacher training and redeployment }\end{array}$} \\
\hline \multicolumn{6}{|c|}{$\begin{array}{l}\text { Reform the curriculum to focus on core } \\
\text { skills }\end{array}$} \\
\hline & $\begin{array}{l}\text { Provide learning materials and improving } \\
\text { the learning environment }\end{array}$ & & $\begin{array}{l}\text { Textbooks, exercise books, pencils, } \\
\text { equipment }\end{array}$ & $\begin{array}{l}\text { School accounts and inventory } \\
\text { records (Schools/MoE), budget } \\
\text { disbursements }\end{array}$ & $\begin{array}{l}\text { teachers, repetition and drop out, } \\
\text { cooperation from school } \\
\text { committees, cooperation with } \\
\text { other providers of primary }\end{array}$ \\
\hline \multicolumn{6}{|c|}{ Redefine the roles of local authorities } \\
\hline & $\begin{array}{l}\text { Decentralize decision-making to district } \\
\text { and school-level administrators, and } \\
\text { parents' representatives }\end{array}$ & & & & \\
\hline
\end{tabular}




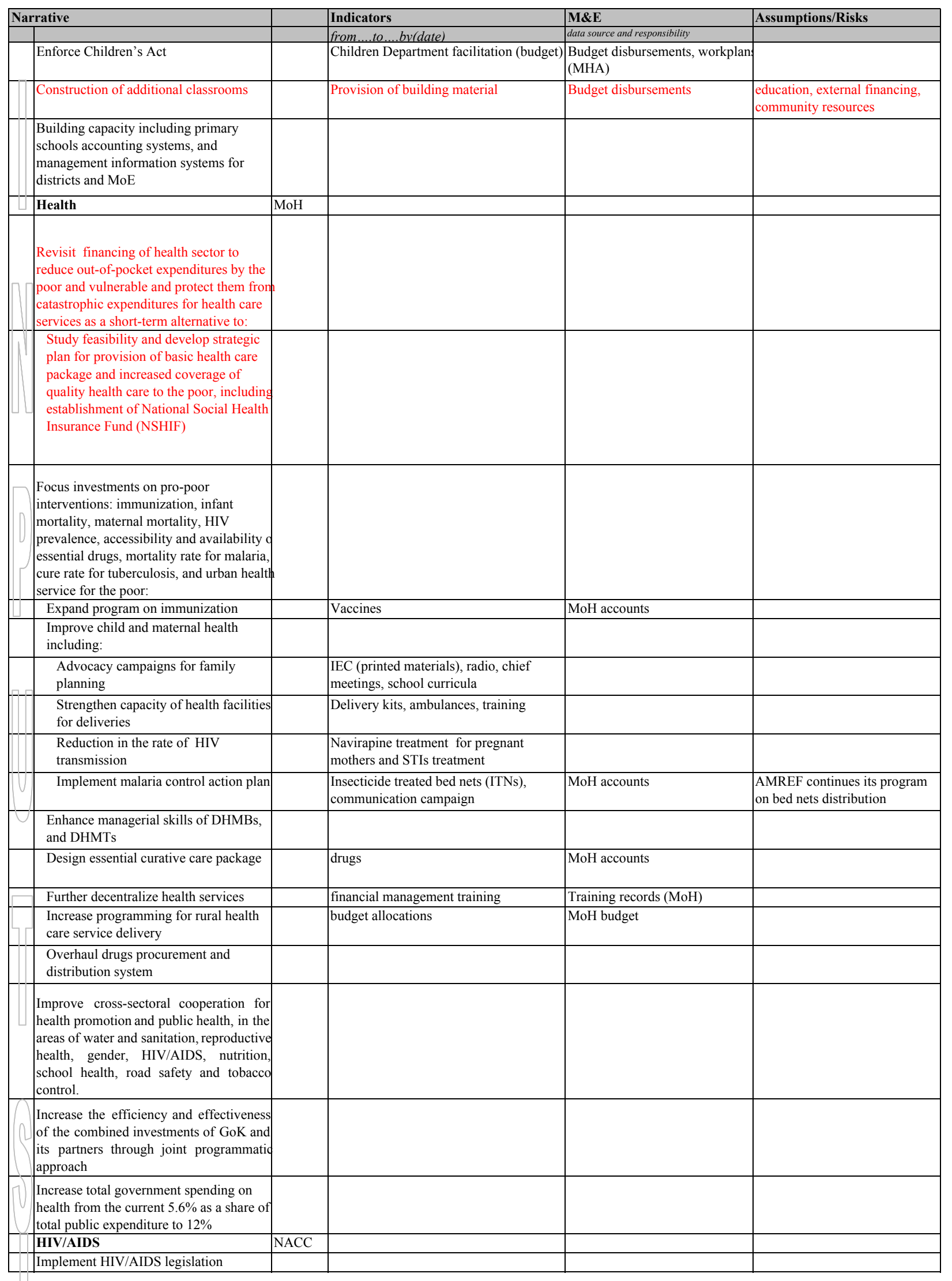




\begin{tabular}{|c|c|c|c|c|}
\hline \multicolumn{2}{|c|}{ Narrative } & \multirow{2}{*}{$\begin{array}{l}\text { Indicators } \\
\text { from ....to ....bv (date) }\end{array}$} & \multirow{2}{*}{\begin{tabular}{|l|} 
M\&E \\
data source and responsibility \\
\end{tabular}} & \multirow[t]{2}{*}{ Assumptions/Risks } \\
\hline & & & & \\
\hline$\square$ & $\begin{array}{l}\text { Strengthen multi-sectoral response to } \\
\text { HIV/AIDS }\end{array}$ & & & \\
\hline & $\begin{array}{l}\text { Intensify HIV/AIDS awareness and } \\
\text { behavioral change communication } \\
\text { campaign }\end{array}$ & $\begin{array}{l}\text { Condom programming, provision of } \\
\text { information and education }\end{array}$ & & $\begin{array}{l}\text { Availability of funds for ARV } \\
\text { drugs; interagency coordination; }\end{array}$ \\
\hline & $\begin{array}{l}\text { Coordinate strategies for prevention, } \\
\text { treatment and mitigation }\end{array}$ & & & \\
\hline & $\begin{array}{l}\text { Develop a roll-out plan for the increasing } \\
\text { amount of resources devoted to treatment }\end{array}$ & & & \\
\hline & Intensify prevention activities including: & & & \\
\hline & Voluntary counseling and testing & $\begin{array}{l}\text { Establishing VCT centers, provide trainin } \\
\text { and equipment }\end{array}$ & & \\
\hline & $\begin{array}{l}\text { Develop capacity building plans for privat } \\
\text { and public agencies involved in } \\
\text { HIV/AIDS programs }\end{array}$ & & & \\
\hline$\square$ & $\begin{array}{l}\text { Develop a creative and strategic approach } \\
\text { for caring for and supporting the rapidly } \\
\text { increasing number of orphans }\end{array}$ & & & \\
\hline
\end{tabular}




\begin{tabular}{|c|c|c|c|c|c|}
\hline Log & sical Framework Matrix for KeI & nya's Ec & conomic Recovery Strategy for & Wealth and Employmen & tt Generation (ERS) \\
\hline PA & RT B.2: EQUITY AND POVER & RTY RE & EDUCTION Human Resource D & Development: Labor & \\
\hline Nari & rative & & Indicators & M\&E & Assumptions/Risks \\
\hline & & & from ....to....bv(date) & data source and responsibility & \\
\hline Obj & ective & & & & \\
\hline & Poverty Reduction & & $\begin{array}{l}\text { Reduce proportion of the people below } \\
\text { the absolute poverty lines (Kenya and } \\
\text { \$1PPP) by } 10 \% \text { by } 2006 \text { from } 57 \% \text { in } \\
1997 \text { (MDG1) }\end{array}$ & $\begin{array}{l}\text { Kenya Living Standard Survey- } \\
\text { KLSS (CBS) (in design stage) }\end{array}$ & \\
\hline Deve & lopment outcomes & & & & \\
\hline & Strengthen employment creation and pr & roductivit & & & \\
\hline & \begin{tabular}{|l|l|} 
Job creation \\
\end{tabular} & & $\begin{array}{l}\text { Half a million jobs created annually in } \\
2003-2006\end{array}$ & $\begin{array}{l}\text { Labor force Survey (CBS), Jua } \\
\text { Kali associations records }\end{array}$ & $\begin{array}{l}\text { Ther will be continious } \\
\text { investment by both local and } \\
\text { overseas organisations }\end{array}$ \\
\hline & $\begin{array}{l}\text { Promotion of enabling environment for } \\
\text { industrial development }\end{array}$ & & Increased investor confidence & $\begin{array}{l}\text { Quarterly Business Expectation } \\
\text { Enquiry (CBS) }\end{array}$ & Macro economic stability \\
\hline & $\begin{array}{l}\text { Increase productivity of factors of } \\
\text { production }\end{array}$ & & Industrial labor productivity rises & $\begin{array}{l}\text { Survey of Industrial Production } \\
\text { (CBS) }\end{array}$ & \\
\hline Out & puts & & & & \\
\hline & Employment and Productivity & & & & \\
\hline & New employment policy & & Employment policy approved by 2004 & & Macro economic stability \\
\hline & Decreased labor costs & & $\begin{array}{l}\text { Average industrial gross wage for low- } \\
\text { skill labor declines }\end{array}$ & & Macro economic stability \\
\hline & Reduced industrial unrest & COTU & Frequency of labour inspections increasedl & dIndustrial reports & $\begin{array}{l}\text { The new employment policy is } \\
\text { implemented }\end{array}$ \\
\hline & & $\begin{array}{l}\text { FKE, } \\
\text { CPU, } \\
\text { MoL }\end{array}$ & $\begin{array}{l}\text { Ratio of workmen compensation cases } \\
\text { processed to total increased }\end{array}$ & & \\
\hline & $\begin{array}{l}\text { More efficient resolution of industrial } \\
\text { disputes }\end{array}$ & $\begin{array}{l}\text { Industrial } \\
\text { court }\end{array}$ & No of disputes settled per month increase & Industrial reports & $\begin{array}{l}\text { The new employment policy is } \\
\text { implemented }\end{array}$ \\
\hline & Productivity policy in place & & & & \\
\hline & Adult literacy improved & & Literacy rate increased & & \\
\hline Acti & vities/Policies & \begin{tabular}{|l|l|} 
Impl. \\
Agency
\end{tabular} & Inputs & & \\
\hline & Labor & & & & \\
\hline & \begin{tabular}{|l|} 
Employment Generation \\
\end{tabular} & & & & \\
\hline & Completion of employment policy & & 5 workshops by end of 2003 & Finalised policy & \\
\hline & Review of Labour Laws & & $\begin{array}{l}10 \text { consultative meetings and seminars by } \\
2005\end{array}$ & Labour laws & \\
\hline & $\begin{array}{l}\text { Identify inefficiencies that have led to } \\
\text { high unemployment and high labour costs; } \\
\text { and implement reforms to improve labour } \\
\text { market flexibility }\end{array}$ & MoL & & Survey reports & \\
\hline & $\begin{array}{l}\text { Strengthen linkage between education, } \\
\text { training and industry }\end{array}$ & $\mathrm{MoL}$ & $\begin{array}{l}\text { Establish Information Center for } \\
\text { networking between education, training \& } \\
\text { industry. }\end{array}$ & Labour force surveys & \\
\hline & $\begin{array}{l}\text { Industrial and Labor Conflict } \\
\text { Management }\end{array}$ & $\begin{array}{l}\text { Mol, } \\
\text { MTI, } \\
\text { MoF, } \\
\text { MPND }\end{array}$ & & & \\
\hline$\sqrt{7}$ & $\begin{array}{l}\text { Review existing industrial labour } \\
\text { framework to promote harmony, } \\
\text { employment and productivity incl. wage } \\
\text { guidelines and minumum wage legislation }\end{array}$ & $\begin{array}{l}\text { Mol, } \\
\text { MTI, } \\
\text { MoF, } \\
\text { MPND }\end{array}$ & & & \\
\hline & Enhance dispute settlement machinery & & Settlement of industrial disputes & & $\begin{array}{l}\text { The new employment policy is } \\
\text { implemented }\end{array}$ \\
\hline 邹 & $\begin{array}{l}\text { Strengthen the Tripartite Committee } \\
\text { Secretariat }\end{array}$ & & Capacity building & & $\begin{array}{l}\text { The new employment policy is } \\
\text { implemented }\end{array}$ \\
\hline & $\begin{array}{l}\text { Enhance efficiency and strengthen labour } \\
\text { inspection services }\end{array}$ & & $\begin{array}{l}\text { Labour inspection services for dispute } \\
\text { prevention and resolution }\end{array}$ & & \\
\hline & Promote international labour relations & & $\begin{array}{l}\text { Participation in international labour } \\
\text { matters }\end{array}$ & & \\
\hline (3) & $\begin{array}{l}\text { Reduce backlog of workmen's } \\
\text { compensation cases }\end{array}$ & & Compensation cases & & \\
\hline & Productivity & & & & \\
\hline
\end{tabular}




\begin{tabular}{|c|c|c|c|c|c|}
\hline \multicolumn{2}{|c|}{ Narrative } & & \multirow{2}{*}{$\begin{array}{l}\text { Indicators } \\
\text { from ....to ....bv(date) }\end{array}$} & \multirow{2}{*}{\begin{tabular}{|l|} 
M\&E \\
data source and responsibility \\
\end{tabular}} & \multirow[t]{2}{*}{ Assumptions/Risks } \\
\hline & & & & & \\
\hline & $\begin{array}{l}\text { Implement Strategic Plan of the } \\
\text { Productivity Center }\end{array}$ & & & & Strategic plan will be completed \\
\hline 日 & $\begin{array}{l}\text { Finalize productivity policy \& } \\
\text { disseminate }\end{array}$ & & $\begin{array}{l}\text { Policy formulation, development \& } \\
\text { dissemination }\end{array}$ & & \\
\hline (8) & $\begin{array}{l}\text { Measure productivity of factors of } \\
\text { production. }\end{array}$ & $\begin{array}{l}\text { Mol, } \\
\text { MTI, } \\
\text { MoF }\end{array}$ & $\begin{array}{l}\text { Measuring factors of production using } \\
\text { different measurement criteria for the } \\
\text { entire economy. }\end{array}$ & & \\
\hline 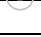 & Strengthen literacy programs & & & & \\
\hline
\end{tabular}




\begin{tabular}{|c|c|c|c|}
\hline \multicolumn{4}{|c|}{ Logical Framework Matrix for Kenya's Economic Recovery Strategy for Wealth and Employment Generation (ERS) } \\
\hline \multicolumn{4}{|c|}{ PART B.3: EQUITY AND POVERTY REDUCTION Agriculture, Rural Development and Environment } \\
\hline Narrative & Indicators & M\&E & Assumptions/Risks \\
\hline & from ....to....bv(date) & data source and responsibility & \\
\hline \multicolumn{4}{|l|}{ Objective } \\
\hline \multirow[t]{2}{*}{ Poverty Reduction } & $\begin{array}{l}\text { Reduce proportion of the people below th } \\
\text { absolute poverty lines (Kenya and \$1PPP) } \\
\text { by } 10 \% \text { by } 2006 \text { from } 57 \% \text { in } 1997 \\
\text { (MDG1) }\end{array}$ & $\begin{array}{l}\text { Kenya Living Standard Survey- } \\
\text { KLSS (CBS) (in design stage) }\end{array}$ & \\
\hline & $\begin{array}{l}\text { Reduce proportion of people living in } \\
\text { hunger by } 10 \% \text { by } 2006 \text { (MDG2) }\end{array}$ & MoA, WFP, FAO, KLSS & \\
\hline \multicolumn{4}{|l|}{ Development Outcomes } \\
\hline & & & \\
\hline \multicolumn{4}{|l|}{ Agriculture and livestock } \\
\hline \multirow[t]{2}{*}{$\begin{array}{l}\text { Agricultural sector becomes more } \\
\text { competitive globally. }\end{array}$} & $\begin{array}{l}\text { Value of agricultural exports rises by } 3 \\
\text { percent per year during 2003-06 }\end{array}$ & $\begin{array}{l}\text { National Accounts/Economic } \\
\text { survey data provided annually by } \\
\text { the Central Bureau of Statistics. }\end{array}$ & $\begin{array}{l}\text { Infrastructure (roads, energy, } \\
\text { communications) improved. } \\
\text { Supportive legislation is passed } \\
\text { by parliament. }\end{array}$ \\
\hline & & & $\begin{array}{l}\text { Trade agreements create a level } \\
\text { playing field. }\end{array}$ \\
\hline $\begin{array}{l}\text { Marketing system for smallholders } \\
\text { becomes more efficient. }\end{array}$ & $\begin{array}{l}\text { The ratio between small farmer price } \\
\text { received and world market price for coffee } \\
\text { rise from } 30 \% \text { to } 70 \% \text { by } 2006 \text {. } \\
\text { Marketing margin between consumer and } \\
\text { producer prices for grains falls }\end{array}$ & $\begin{array}{l}\text { Data from the ministry of } \\
\text { cagriculture, cooperatives, and } \\
\text { commodity boards, KLSS (CBS) } \\
\text { Rural Market Prices Survey } \\
\text { (CBS), }\end{array}$ & $\begin{array}{l}\text { Supportive legislation is passed } \\
\text { by parliament. Reform of } \\
\text { cooperatives and commodity } \\
\text { boards implemented. }\end{array}$ \\
\hline $\begin{array}{l}\text { Incomes of crop and livestock producers } \\
\text { increase. }\end{array}$ & $\begin{array}{l}\text { Income rises in communities that benefit } \\
\text { from rehabilitation of irrigation works, } \\
\text { compared with a baseline. }\end{array}$ & $\begin{array}{l}\text { Participatory Poverty } \\
\text { Assessments, KLSS (CBS) }\end{array}$ & \\
\hline Food security increases. & $\begin{array}{l}\text { Headcount of food insecure populations } \\
\text { falls, proportion of malnourished children } \\
\text { falls }\end{array}$ & $\begin{array}{l}\text { KLSS (CBS), malnutrition data } \\
\text { from the ministry of health, } \\
\text { WFP, FAO }\end{array}$ & Rainfall patterns are normal. \\
\hline Animals are healthy and more productive. & $\begin{array}{l}\text { Incidences of animal disease outbreaks } \\
\text { declines by } 2006\end{array}$ & $\begin{array}{l}\text { Ministry of agriculture, } \\
\text { department of veterinary } \\
\text { services, Husbandry Surveys } \\
\text { (ILRI) }\end{array}$ & $\begin{array}{l}\text { Animal movements are } \\
\text { controlled. }\end{array}$ \\
\hline \multicolumn{4}{|l|}{ Rural Water } \\
\hline $\begin{array}{l}\text { Increase access to drinking water in rural } \\
\text { areas }\end{array}$ & $\begin{array}{l}\text { Increase access to } 60 \% \text { coverage in rural } \\
\text { areas by } 2006 .\end{array}$ & $\begin{array}{l}\text { Ministry of water resources, } \\
\text { KLSS and census (CBS) }\end{array}$ & $\begin{array}{l}\text { Catchment areas are protected fo } \\
\text { water supply; multi-donor sector } \\
\text { investment program }\end{array}$ \\
\hline $\begin{array}{l}\text { Health improves in beneficiary } \\
\text { communities. }\end{array}$ & $\begin{array}{l}\text { Incidence of waterborne diseases declines } \\
\text { in 2003-6. }\end{array}$ & $\begin{array}{l}\text { KDHS (CBS), MoH surveillance } \\
\text { data, and reported data on } \\
\text { outbreaks of waterborne diseases. }\end{array}$ & $\begin{array}{l}\text { Community members practice } \\
\text { good hygienic standards. }\end{array}$ \\
\hline Sustainable use of water resources & Reduced conflicts over water resources. & $\begin{array}{l}\text { MoRMD, WRMA, District } \\
\text { Commisioner and Officer } \\
\text { Commanding Police } \\
\text { Division/Office of the President } \\
\text { and NGOs data. }\end{array}$ & $\begin{array}{l}\text { Consensus and clear institutional } \\
\text { linkages and support; cooperation } \\
\text { among communities }\end{array}$ \\
\hline \multirow{2}{*}{\multicolumn{4}{|c|}{ Land Resources }} \\
\hline & & & \\
\hline $\begin{array}{l}\text { Increased investment and reduced } \\
\text { conflicts over land. }\end{array}$ & $\begin{array}{l}\text { Rural fixed investment in the land } \\
\text { increased }\end{array}$ & $\begin{array}{l}\text { Agricultural Production Survey } \\
\text { (CBS) }\end{array}$ & $\begin{array}{l}\text { People demand titles to the land } \\
\text { to which they have user rights. }\end{array}$ \\
\hline $\begin{array}{l}\text { Improved land use planning and } \\
\text { administration. }\end{array}$ & Increased use of agricultural inputs & $\begin{array}{l}\text { Ministry of Lands and } \\
\text { Settlements }\end{array}$ & $\begin{array}{l}\text { Input prices not above } \\
\text { international market levels }\end{array}$ \\
\hline \multicolumn{4}{|l|}{ Environment } \\
\hline Conservation of the environment & Hectage of conserved habitat & MoA, KWS, MLS & \\
\hline & $\begin{array}{l}\text { Hectage of forestry remaining and } \\
\text { reclaimed }\end{array}$ & MoA, KWS, MLS & \\
\hline & Number of wild animals by species & KWS, ILRI & \\
\hline \multicolumn{4}{|l|}{ Outputs } \\
\hline \multicolumn{4}{|l|}{ Agriculture and livestock } \\
\hline (U) $\begin{array}{l}\text { Agricultural research institutes } \\
\text { consolidated }\end{array}$ & $\begin{array}{l}\text { Some of research institutes merged and } \\
\text { staff rationalized by } 2006\end{array}$ & & \\
\hline
\end{tabular}




\begin{tabular}{|c|c|c|c|c|}
\hline \multicolumn{2}{|c|}{ Narrative } & \multirow{2}{*}{$\begin{array}{l}\text { Indicators } \\
\text { from ....to ....bv(date) }\end{array}$} & \multirow{2}{*}{\begin{tabular}{|l|}
$\mathbf{M} \& \mathbf{E}$ \\
data source and responsibility \\
\end{tabular}} & \multirow[t]{2}{*}{ Assumptions/Risks } \\
\hline & & & & \\
\hline 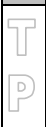 & $\begin{array}{l}\text { Linkages between farmers, the research } \\
\text { system, and extension strengthened. }\end{array}$ & $\begin{array}{l}75 \% \text { of farmers able to chose extension } \\
\text { services BY } 2006\end{array}$ & Farmer score cards (MoA) & $\begin{array}{l}\text { Government adopts a strategy } \\
\text { that increases the participation of } \\
\text { farmers in setting priorities for } \\
\text { research and extension. }\end{array}$ \\
\hline$(0)$ & $\begin{array}{l}\text { Management and control of pests and } \\
\text { diseases improved. }\end{array}$ & Number of hectares treated. & Annual report by MoA. & $\begin{array}{l}\text { Animal movements are } \\
\text { controlled. }\end{array}$ \\
\hline$\square$ & & Proportion of livestock vaccinated. & & \\
\hline$\$$ & Market information system improved. & $\begin{array}{l}\text { Market information bulletins are issued } \\
\text { weekly/monthly, distributed to DAOs and } \\
\text { communities, and posted on the web. }\end{array}$ & $\begin{array}{l}\text { MoA, DAOs, cooperatives and } \\
\text { farmer associations }\end{array}$ & $\begin{array}{l}\text { Supportive infrastructure is } \\
\text { available in districts. }\end{array}$ \\
\hline & $\begin{array}{l}\text { Sanitary and phytosanitary standards are } \\
\text { met. }\end{array}$ & $\begin{array}{l}\text { Proportion of agricultural products and } \\
\text { produce for export rejected for SPS failure } \\
\text { declines by } 80 \% \text { by } 2006\end{array}$ & $\begin{array}{l}\text { Kenya plant health inspectorate } \\
\text { eservices data. }\end{array}$ & $\begin{array}{l}\text { International standards remain } \\
\text { constant and if they change } \\
\text { donors help Kenya comply. }\end{array}$ \\
\hline & & & & $\begin{array}{l}\text { Quality of pesticides is as } \\
\text { claimed. }\end{array}$ \\
\hline & $\begin{array}{l}\text { Parastatal reforms and rationalization } \\
\text { carried out }\end{array}$ & Legislation passed. Parastatals rationalized & Published in the Kenya gazette. & $\begin{array}{l}\text { Supportive legislation is passed } \\
\text { by parliament. }\end{array}$ \\
\hline & Marketed beef output rises. & Marketed beef output increase per year. & $\begin{array}{l}\text { Ministry of livestock and } \\
\text { fisheries, marketing division. }\end{array}$ & $\begin{array}{l}\text { Incidence of diseases remain } \\
\text { under control. }\end{array}$ \\
\hline \multirow[t]{3}{*}{ O } & $\begin{array}{l}\text { Livestock marketing infrastructure } \\
\text { (holding grounds, watering points) } \\
\text { expanded. }\end{array}$ & Number of holding grounds rehabilitated & MoLF & \\
\hline & & Number of watering points rehabilitated. & MoA, MoW & \\
\hline & $\begin{array}{l}\text { MoA structure of spending pro priority } \\
\text { program }\end{array}$ & $\begin{array}{l}\text { Proportion of MoA budget devoted to } \\
\text { priority programs; number of parastatals } \\
\text { rationalized }\end{array}$ & & \\
\hline & \multicolumn{4}{|l|}{ Rural Water } \\
\hline u & Boreholes & 1,000 boreholes per year $2003-06$. & Ministry of water resources. & $\begin{array}{l}\text { Communities participate with } \\
\text { funding and performing O\&M. }\end{array}$ \\
\hline & Small dams/pans & 100 dams/pans in the ASALs per year. & $\begin{array}{l}\text { Ministry of water resources } \\
\text { implementation reports. }\end{array}$ & $\begin{array}{l}\text { Communities participate with } \\
\text { funding and performing O\&M. }\end{array}$ \\
\hline \multirow[t]{2}{*}{$\sqrt{1+1}$} & Irrigation systems. & 20 schemes constructed. & $\begin{array}{l}\text { Ministry of water resources } \\
\text { implementation reports. }\end{array}$ & $\begin{array}{l}\text { Communities participate with } \\
\text { funding and performing O\&M. }\end{array}$ \\
\hline & & & Irrigation Board. & \\
\hline & Irrigation canals and flood control dikes. & Number of km of canal rehabilitated. & Ministry of water resources. & $\begin{array}{l}\text { Communities participate with } \\
\text { funding and performing O\&M. }\end{array}$ \\
\hline & & Number of dikes rehabilitated. & & \\
\hline 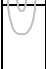 & Irrigation policy adopted. & Legislation passed. & Published in the Kenya gazette & $\begin{array}{l}\text { Supportive legislation is passed } \\
\text { by parliament. }\end{array}$ \\
\hline \multirow{2}{*}{$\square$} & Land reclaimed. & $\begin{array}{l}\text { 1. Implement } 44 \text { community based } \\
\text { development projects in ASAL districts. }\end{array}$ & & \\
\hline & & $\begin{array}{l}\text { 2. Provide specialized training to } 200 \\
\text { project beneficiaries and communities. }\end{array}$ & & \\
\hline C & Land Resources & & & \\
\hline (1) & Titles issued. & $\begin{array}{l}\text { Number of titles issued each year } \\
2003-06 .\end{array}$ & $\begin{array}{l}\text { Ministry of Lands and } \\
\text { Settlements. }\end{array}$ & $\begin{array}{l}\text { Adjudication mechanisms are } \\
\text { efficient. }\end{array}$ \\
\hline- & Land information system modernized. & $\begin{array}{l}\text { Proportion of land records that are } \\
\text { available in electronic format rises by } 30 \% \\
\text { by } 2006 .\end{array}$ & $\begin{array}{l}\text { Ministry of Lands and } \\
\text { Settlements. }\end{array}$ & $\begin{array}{l}\text { Supportive infrastructure is in } \\
\text { place. }\end{array}$ \\
\hline & Land laws harmonized. & Legislation passed. & Published in the Kenya gazette. & $\begin{array}{l}\text { Supportive legislation passed by } \\
\text { the parliament. }\end{array}$ \\
\hline \multicolumn{5}{|c|}{ Environment } \\
\hline & $\begin{array}{l}\text { National Environmental Authority fully } \\
\text { operational }\end{array}$ & $\begin{array}{l}\text { NEMA fully operational by } 2005, \text { Board, } \\
\text { Provincial and District Environment } \\
\text { Committees, Standards Enforcement } \\
\text { Committee and National Environmental } \\
\text { Council established }\end{array}$ & $\begin{array}{l}\text { Gazette and implementation } \\
\text { reports }\end{array}$ & \\
\hline & Environmental standards in place & No of projects subjected to EIA & KWS & \\
\hline & & Prosecuted cases of EIA & & \\
\hline & Natural resources inventory & Natural resources inventory carried out & KWS & \\
\hline
\end{tabular}




\begin{tabular}{|l|l|l|l|l|l|}
\hline \multicolumn{2}{|l|}{ Narrative } & & Indicators & M\&E & Assumptions/Risks \\
\hline & & from ...to...bv(date) & data source and responsibility & \\
\hline & & $\begin{array}{l}\text { Natural resource valuation undertaken by } \\
2007\end{array}$ & & \\
\hline & Community workplans & $\begin{array}{l}\text { No. of workplans completed and } \\
\text { implemented }\end{array}$ & & \\
\hline & Conservation of wildlife & Hectage of conserved habitat & KWS & \\
\hline
\end{tabular}




\begin{tabular}{|c|c|c|c|c|}
\hline Narrative & & & \multirow{2}{*}{\begin{tabular}{|l|} 
M\&E \\
data source and responsibility \\
\end{tabular}} & \multirow[t]{2}{*}{ Assumptions/Risks } \\
\hline \begin{tabular}{|l|l|} 
& \\
\end{tabular} & \multirow{2}{*}{\multicolumn{2}{|c|}{\begin{tabular}{|l|l} 
& from....to.....by (date) \\
$\begin{array}{l}\text { Implementin } \\
\text { g Agency }\end{array}$ & Inputs
\end{tabular}}} & & \\
\hline Activities/Policies & & & & \\
\hline Agriculture and livestock & MALD & & & \\
\hline $\begin{array}{l}\text { Restructure and rationalize agricultural } \\
\text { research }\end{array}$ & & & & $\begin{array}{l}\text { Supportive legislation passed by } \\
\text { Parliament }\end{array}$ \\
\hline $\begin{array}{l}\text { Implement National Agricultural } \\
\text { Extension policy emphasizing demand- } \\
\text { driven services and private sector } \\
\text { participation /Establish database for } \\
\text { extension planning and performance } \\
\text { monitoring }\end{array}$ & & & & $\begin{array}{l}\text { Needed analytical work } \\
\text { undertaken as a basis for reform } \\
\text { of agricultural marketing boards } \\
\text { and other regulatory issues }\end{array}$ \\
\hline $\begin{array}{l}\text { Carrying out PRA throughout the country, } \\
\text { facilitated by extensionists. }\end{array}$ & & & $\begin{array}{l}\text { Statements of expenditures, } \\
\text { Public Expenditure Review }\end{array}$ & $\begin{array}{l}\text { Actual allocations match what is } \\
\text { planned at the beginning of the } \\
\text { budget year. }\end{array}$ \\
\hline $\begin{array}{l}\text { Develop strategy to improve public sector } \\
\text { efficiency in agriculture and livestock, } \\
\text { including rationalization of parastatals }\end{array}$ & & & & \\
\hline $\begin{array}{l}\text { Develop strategy for deepening markets o } \\
\text { agricultural financial services }\end{array}$ & & & & \\
\hline Liberalize and regulate inputs market & & & & \\
\hline$\left[\begin{array}{l}\text { Promote commercialization of farm } \\
\text { products including reducing transport cost } \\
\text { by improving rural roads and reducing fue } \\
\text { taxes; reducing irrigation and factory } \\
\text { operating costs by bringing down } \\
\text { electricity costs; and improving access to } \\
\text { market information by strengthening } \\
\text { communications. }\end{array}\right.$ & & & & \\
\hline \begin{tabular}{l|l} 
Revitalize quality assurance laboratory. \\
\end{tabular} & & & & \\
\hline \begin{tabular}{|l|l|} 
Provide crop and livestock information \\
services through radio, bulletins, internet, \\
and the like.
\end{tabular} & & & & \\
\hline $\begin{array}{l}\text { Develop a coherent land policy to address } \\
\text { land use and administration, land tenure, } \\
\text { and land delivery systems }\end{array}$ & & & & \\
\hline Liberalize maize and sugar markets & & & & \\
\hline $\begin{array}{l}\text { Implement plans to liberalize the } \\
\text { pyrethrum sector, and restrict the } \\
\text { pyrethrum board to regulatory functions }\end{array}$ & & & & \\
\hline $\begin{array}{l}\text { Coffee: implement reforms in the coffee } \\
\text { sector with the objective of increasing the } \\
\text { share of final sales that farmers receive }\end{array}$ & & & & \\
\hline $\begin{array}{l}\text { Cotton: Reestablish Cotton Board, clear } \\
\text { outstanding debts, expand irrigation } \\
\text { schemes, review Cotton Act, encourage } \\
\text { small scale ginning }\end{array}$ & MoALD & & & \\
\hline $\begin{array}{l}\text { Rice: rehabilitate irrigation schemes to } \\
\text { enhance rice production }\end{array}$ & MoALD & & & \\
\hline $\begin{array}{l}\text { Livestock. Implement strategy for disease } \\
\text { outbreak prevention and control.Introduce } \\
\text { single permit system for cattle movement. } \\
\text { Review options for a decentralized and } \\
\text { private sector provided network of } \\
\text { slaughterhouses. Expand access to water } \\
\text { sources. Improve security. Provide } \\
\text { breeding services (cattle, goats, sheep). }\end{array}$ & & & & \\
\hline $\begin{array}{l}\text { Cooperatives: review Cooperative } \\
\text { Societies Act (1997), address } \\
\text { indebtedness, sensitize coop members on } \\
\text { their rights }\end{array}$ & MoCD & & & \\
\hline
\end{tabular}




\begin{tabular}{|c|c|c|c|c|c|}
\hline \multicolumn{2}{|c|}{ Narrative } & & \multirow{2}{*}{$\begin{array}{l}\text { Indicators } \\
\text { from ....to ....bv(date) } \\
\end{array}$} & \multirow{2}{*}{\begin{tabular}{|l|}
$\mathbf{M} \& \mathbf{E}$ \\
data source and responsibility \\
\end{tabular}} & \multirow[t]{2}{*}{ Assumptions/Risks } \\
\hline & & & & & \\
\hline$\sqrt{1}$ & $\begin{array}{l}\text { Restructure public spending in the } \\
\text { Ministry of Agriculture to allocate a } \\
\text { greater share of resources to priority } \\
\text { programs }\end{array}$ & & & & \\
\hline & Rural Water & & & & \\
\hline & Water Conservation & & & & \\
\hline D) & Drill boreholes. & & & $\begin{array}{l}\text { Statements of expenditures, } \\
\text { Public Expenditure Review }\end{array}$ & $\begin{array}{l}\text { Actual allocations match what is } \\
\text { planned at the beginning of the } \\
\text { budget year. }\end{array}$ \\
\hline & Rehabilitate dams and pans & & & Public expenditure review. & \\
\hline \multirow[t]{4}{*}{ 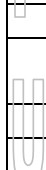 } & Rehabilitate 20 irrigation systems. & & & & \\
\hline & $\begin{array}{l}\text { Rehabilitate irrigation canals and flood } \\
\text { control dikes }\end{array}$ & & & & \\
\hline & Formulation of a land policy. & & & & \\
\hline & Formulation of an agricultural policy. & & & & \\
\hline \multirow[t]{3}{*}{$\checkmark$} & Formulation of irrigation policy. & & & & \\
\hline & $\begin{array}{l}\text { Carry out geophysical and hydrogeologica } \\
\text { and hydrological surveys. }\end{array}$ & & & & \\
\hline & Implement the Water Act 2000. & & & & \\
\hline$\square$ & $\begin{array}{l}\text { Land reclamation: implementation of } \\
\text { community projects. }\end{array}$ & & & & \\
\hline 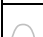 & Land Resources & MoLS & & & \\
\hline \multirow[t]{5}{*}{$(1)$} & $\begin{array}{l}\text { Develop a coherent land policy to address } \\
\text { land use and administration, land tenure, } \\
\text { and land delivery systems }\end{array}$ & & & & \\
\hline & $\begin{array}{l}\text { Land valuation, registration of titles, and } \\
\text { land administration. }\end{array}$ & & & & \\
\hline & $\begin{array}{l}\text { Convening tribunals to hear and resolve } \\
\text { land/boundary disputes. }\end{array}$ & & & & \\
\hline & $\begin{array}{l}\text { Procurement of modern survey and } \\
\text { mapping equipment, and computerization } \\
\text { of land records }\end{array}$ & & & & \\
\hline & $\begin{array}{l}\text { Implementation of recommendations of } \\
\text { Njonjo Commission of Enquiry }\end{array}$ & & & & \\
\hline$\square$ & Environment & & & & \\
\hline D) & $\begin{array}{l}\text { Environmental Management: implement } \\
\text { National Environment Action Plan } \\
\text { (NEAP) and Environment Management } \\
\text { and Coordination Act (1999), implement } \\
\text { WSSD and MDG, implement Lake } \\
\text { Victoria Environmental Management } \\
\text { Project, and consolidate National } \\
\text { Environment Management Authority } \\
\text { functions }\end{array}$ & NEMA & & & \\
\hline & $\begin{array}{l}\text { Forestry: Implement Forestry } \\
\text { Development Policy, enforce Forestry Act } \\
\text { and promote private sector participation in } \\
\text { Afforestation and management of forest } \\
\text { plantations }\end{array}$ & NEMA & & & \\
\hline$(0)$ & $\begin{array}{l}\text { Wildlife Conservation: work with local } \\
\text { communities in conservation of wildlife } \\
\text { and benefit sharing, manage human- } \\
\text { wildlife conflicts, and strengthen KWS } \\
\text { capacity }\end{array}$ & KWS & $\begin{array}{l}\text { hiring and training of rangers, security } \\
\text { equipment, road rehabilitation and } \\
\text { maintenance of fences }\end{array}$ & & \\
\hline & & & & & \\
\hline
\end{tabular}




\begin{tabular}{|c|c|c|c|}
\hline \multicolumn{4}{|c|}{ Logical Framework Matrix for Kenya's Economic Recovery Strategy for Wealth and Employment Generation (ERS) } \\
\hline \multicolumn{4}{|c|}{ PART B.4: EQUITY AND POVERTY REDUCTION Poverty Targeted Programs } \\
\hline \begin{tabular}{|l|l|l} 
Narrative & \\
\end{tabular} & Indicators & M\&E & Assumptions/Risks \\
\hline & from ....to ....bv(date) & data source and responsibility & \\
\hline \multicolumn{4}{|c|}{ from ....o......vilaate) } \\
\hline \multirow[t]{2}{*}{ Poverty Reduction } & $\begin{array}{l}\text { Reduce proportion of the people below th } \\
\text { absolute poverty lines (Kenya and \$1PPP) } \\
\text { by } 10 \% \text { by } 2006 \text { from } 57 \% \text { in } 1997 \\
\text { (MDG1) }\end{array}$ & $\begin{array}{l}\text { Kenya Living Standard Survey- } \\
\text { KLSS (CBS) (in design stage) }\end{array}$ & \\
\hline & $\begin{array}{l}\text { Reduce proportion of people living in } \\
\text { hunger by } 10 \% \text { by } 2006 \text { (MDG2) }\end{array}$ & MoA, WFP, FAO, KLSS & \\
\hline \multicolumn{4}{|l|}{ Development Outcomes } \\
\hline & & & \\
\hline Poverty Targeted Programs & & & PEC coordination \\
\hline Improve conditions of ASAL's residents & $\begin{array}{l}50 \% \text { of road upgrading to marginalized } \\
\text { ASAL district } 2003-5 \text { and average } \\
\text { transport cost reduced }\end{array}$ & $\begin{array}{l}\text { MRPW reports and weekly retail } \\
\text { market prices (CBS), Rural } \\
\text { Market Prices Survey (CBS) }\end{array}$ & \\
\hline $\begin{array}{l}\text { Conditions of slum dwellers significantly } \\
\text { improved }\end{array}$ & $\begin{array}{l}\text { Income of slum dwellers increased, } \\
\text { incidence of water borne diseases } \\
\text { decreased, incidence of crime in the slum } \\
\text { declined }\end{array}$ & $\begin{array}{l}\text { Poverty map, KLSS with slum } \\
\text { clusters (CBS), KDHS (CBS), } \\
\text { MoH, City Councils, Crime } \\
\text { Investigation Department, UNDF } \\
\text { crime victims survey, APHRC }\end{array}$ & \\
\hline \multirow[t]{2}{*}{$\begin{array}{l}\text { Reduce vulnerability of marginalized } \\
\text { groups }\end{array}$} & \begin{tabular}{|l|} 
Reduced gender disparities in access to \\
primary and seconday education(GDG 4)
\end{tabular} & $\begin{array}{l}\text { School census (MoE), KDHS } \\
\text { (CBS), WMS (CBS) }\end{array}$ & \\
\hline & $\begin{array}{l}\text { Proportion of orphans receiving adequate } \\
\text { care }\end{array}$ & & \\
\hline \multicolumn{4}{|l|}{ Outputs } \\
\hline & & & \\
\hline \multicolumn{4}{|l|}{ Poverty Targeted Programs } \\
\hline \multicolumn{4}{|l|}{ Social Action Fund } \\
\hline $\begin{array}{l}\text { Promote community-driven development } \\
\text { projects }\end{array}$ & more communities benefit & & \\
\hline \multicolumn{4}{|l|}{\begin{tabular}{|l|l|} 
Arid and Semi-Arid Lands (ASALs) & n \\
\end{tabular}} \\
\hline $\begin{array}{l}\text { Increased ASALs incomes and assets from } \\
\text { livestock and tourism activities }\end{array}$ & $\begin{array}{l}\text { Increased value and diversity of } \\
\text { livestock/productive and household assets }\end{array}$ & $\begin{array}{l}\text { Baseline survey based on } \\
\text { enhanced EWS sublocations } \\
\text { samples for March and Sept }\end{array}$ & \\
\hline Improve ASALs nutritional status & Stunting rate reduced during 2003-2008 & & \\
\hline $\begin{array}{l}\text { Improved capacity to deal with disasters in } \\
\text { the ASALs and mitigate their effects }\end{array}$ & $\begin{array}{l}\text { Proportion of food insecure to total ASAL } \\
\text { population reduced }\end{array}$ & & \\
\hline Reduced ASALs conflicts over land & Number of reported land conflicts & & \\
\hline $\begin{array}{l}\text { Gap in service delivery between ASAL } \\
\text { areas and the rest of Kenya narrowed }\end{array}$ & $\begin{array}{l}\text { ASALs enrollment rates increase by } 50 \% \\
\text { by } 2007\end{array}$ & & \\
\hline Improved health status in ASALs & $\begin{array}{l}\text { Gap in morbidity rate in ASALs to overal } \\
\text { morbidity narrowed }\end{array}$ & & \\
\hline Reduced insecurity in ASALs & ASALs cross-border incidences reduced & & \\
\hline $\begin{array}{l}\text { Improved road infrastructure in ASALs } \\
\text { (see Infrastructure section in Economic } \\
\text { Growth Matrix) }\end{array}$ & all major roads rehabilitated & & \\
\hline \multicolumn{4}{|l|}{ Slum Upgrading } \\
\hline Security of tenure improved & $\begin{array}{l}50,000 \text { people a year in } 2004-5 \text { awarded } \\
\text { tenure to the land }\end{array}$ & MLS records & $\begin{array}{l}\text { Community mobilization, } \\
\text { poverty map }\end{array}$ \\
\hline Upgrading plans & $\begin{array}{l}\text { Kibera (Soweto) plan completed in 2004, } \\
\text { Kisumu slum plan completed in } 2004\end{array}$ & MRPW and MLA reports & Establishment of fund \\
\hline $\begin{array}{l}\text { Increase of slum dwellers with access to } \\
\text { clean water and sanitation }\end{array}$ & \begin{tabular}{|l|} 
Coverage for urban water and sanitation \\
services increased by $2 \%$ per year from \\
$73 \%$ to $83 \%$ and $64 \%$ to $74 \%$ respectively
\end{tabular} & $\begin{array}{l}\text { Surveys by MoW with relevant } \\
\text { NGOs, annual reports from } \\
\text { y.water services providers. }\end{array}$ & \\
\hline $\begin{array}{l}\text { Increase in the number of electric } \\
\text { distribution points in the slums }\end{array}$ & $\begin{array}{l}\text { a number of electric distribution points in } \\
\text { the slums provided in } 2004-5\end{array}$ & MoEnergy & Affordabiliy of power \\
\hline \begin{tabular}{l|l} 
Slum road network improved
\end{tabular} & $50 \%$ of slum road network improved & MRPW & \\
\hline
\end{tabular}




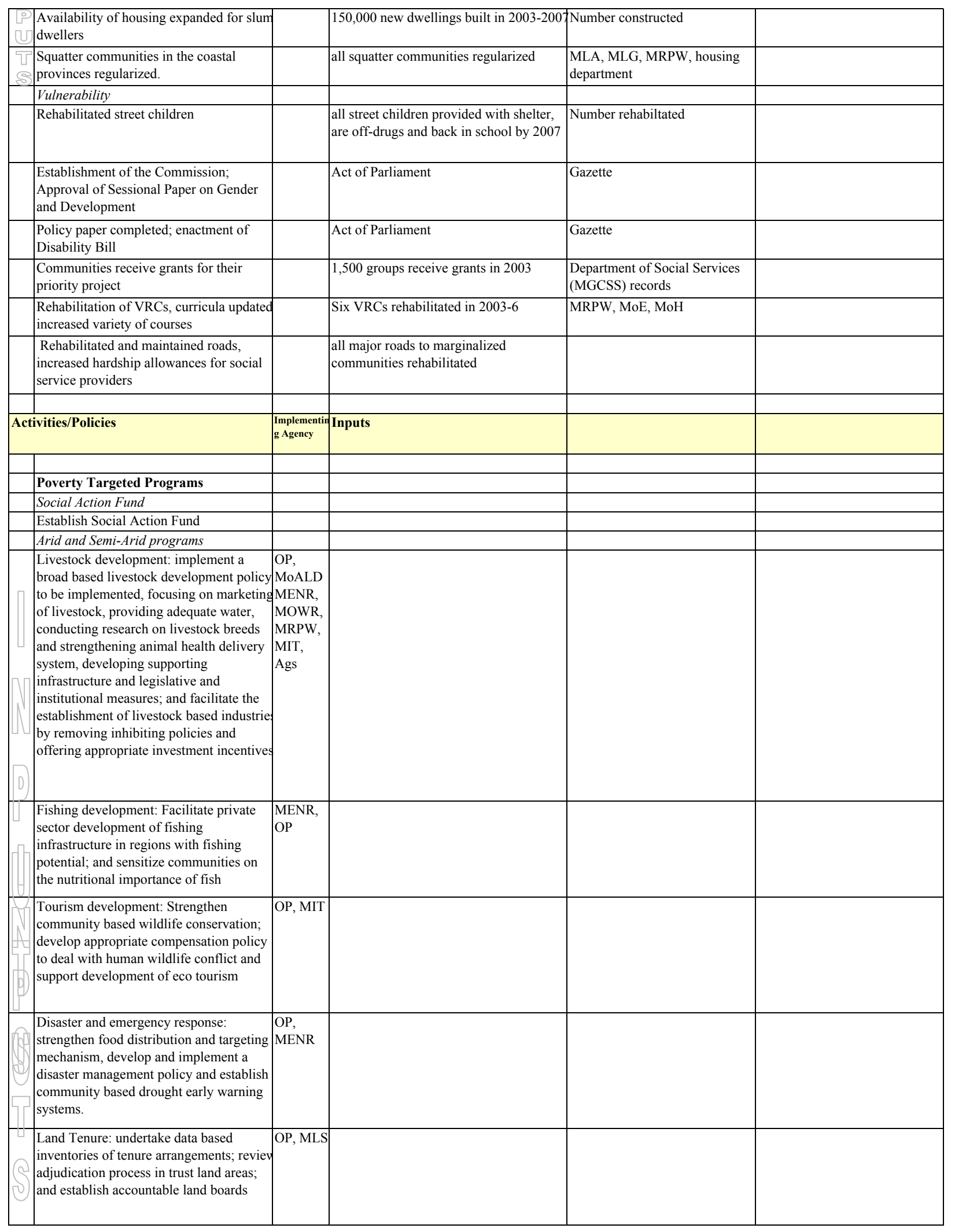




\begin{tabular}{|c|c|c|c|c|c|}
\hline$\sqrt{ }$ & $\begin{array}{l}\text { Education: initiate an out of school } \\
\text { programme for pastoralist children; } \\
\text { develop linkages and equivalences } \\
\text { between non formal and formal education } \\
\text { system; improve schooling facilities; and } \\
\text { strengthen capacities of communities to } \\
\text { ensure better planning and management of } \\
\text { schools }\end{array}$ & OP, MoE & & & \\
\hline & $\begin{array}{l}\text { Health: strengthen community based } \\
\text { health care systems; intensify } \\
\text { immunization of children an other } \\
\text { members of pastoralist community;provid } \\
\text { public health education to communities }\end{array}$ & $\begin{array}{l}\mathrm{OP}, \\
\mathrm{MoH}\end{array}$ & & & \\
\hline & $\begin{array}{l}\text { Security: strengthen security apparatus in } \\
\text { ASALS; ensure that constumary } \\
\text { mechanisms for conflict resolution are } \\
\text { recognized; and increase border } \\
\text { surveillance }\end{array}$ & $\begin{array}{l}\text { OP } \\
\text { (police), } \\
\text { OP (prov } \\
\text { admin) }\end{array}$ & & & \\
\hline (b) & $\begin{array}{l}\text { Infrastructure: bitumize major roads and } \\
\text { rehabilitate others to all weather status; } \\
\text { implement food for work program in food } \\
\text { insecure areas; and mobilize community } \\
\text { maintenance of feeder roads }\end{array}$ & d $\begin{array}{l}\text { OP, } \\
\text { MRPW }\end{array}$ & & & \\
\hline$(5)$ & $\begin{array}{l}\text { Implement Arid Lands Resource } \\
\text { Management Project }\end{array}$ & & & & \\
\hline & Slum Upgrading & & & & \\
\hline & Land adjudication and registration & MSL & $\begin{array}{l}\text { Land surveys, compulsory acquisition } \\
\text { (KSh), legal services, adjudicator services }\end{array}$ & $\begin{array}{l}\text { MLS records and reports, budget } \\
\text { allocation }(\mathrm{MoF}) \text { and accounts } \\
\text { (MLS/MRPW }\end{array}$ & $\begin{array}{l}\text { High level political commitment } \\
\text { needed, dwelling owners' } \\
\text { resistance appeased }\end{array}$ \\
\hline & $\begin{array}{l}\text { Develop slum upgrading and relocation } \\
\text { plan }\end{array}$ & MRPW & $\begin{array}{l}\text { Land physical plan, acquisition of } \\
\text { alternative sites, relocation incentives }\end{array}$ & $\begin{array}{l}\text { MRPW and MLS project reports } \\
\text { UoN (HABRI) Research } \\
\text { Reports; NCC, Mathare4A } \\
\text { (Archdioceses of Nairobi) }\end{array}$ & $\begin{array}{l}\text { Coordination of MRPW with } \\
\text { MoE, MoH, MLS, MoW, } \\
\text { MoGCSS, MoLG, MoEnergy, } \\
\text { MoF, OP and other institutions } \\
\text { (NHC, Habitat) }\end{array}$ \\
\hline D & $\begin{array}{l}\text { Housing: Enact housing legislation to } \\
\text { facilitate private sector development of } \\
\text { affordable housing, surveying current } \\
\text { housing facilities, facilitating construction } \\
\text { (design and building) and financing (tenar } \\
\text { purchase and mortgage-backed securities) }\end{array}$ & $\begin{array}{l}\text { MRPW/ } \\
\text { NHC } \\
\\
\end{array}$ & $\begin{array}{l}\text { Surveys of structure, design, construction } \\
\text { equipment, facilitation of tenant purchase } \\
\text { (NHC), engineers }\end{array}$ & MRPW reports, Habitat & \\
\hline 4 & $\begin{array}{l}\text { Water and sanitation: expansion of water } \\
\text { network and sanitation facilities }\end{array}$ & $\begin{array}{l}\text { MoW/ } \\
\text { Loc Auth }\end{array}$ & Completing surveys & MoW reports & $\begin{array}{l}\text { Private sector participation in the } \\
\text { water and sanitation sectors, } \\
\text { AMREF effective }\end{array}$ \\
\hline 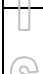 & $\begin{array}{l}\text { Electrification: provision of security } \\
\text { lighting and electricity distribution points }\end{array}$ & MoEn & Manpower, electric materials & MoEnergy, Kenya Power & Energy sector reforms in place \\
\hline (-) & Roads: slum road upgrading & MRPW & In Progress & & \\
\hline & Vulnerability & & & & \\
\hline & Street children and orphans' programs & & $\begin{array}{l}\text { Drug treatments, beds, clothes distributed, } \\
\text { meals, medical treatments, medications, ir } \\
\text { house teachers, vocational training }\end{array}$ & & \\
\hline & $\begin{array}{l}\text { Mainstreaming gender: National Gender } \\
\text { and Development Commission; Sessional } \\
\text { Paper of Gender and Development }\end{array}$ & & legal services, Gazette Notice & & $\begin{array}{l}\text { Attorney General drafts bills, } \\
\text { Parliament approves the } \\
\text { Sessional Paper for Gender and } \\
\text { Development }\end{array}$ \\
\hline & $\begin{array}{l}\text { Youth and vulnerable groups: policy } \\
\text { development; improve targeting and } \\
\text { programming }\end{array}$ & & & & $\begin{array}{l}\text { Attorney General drafts bills, } \\
\text { Parliament approves Disability } \\
\text { Bill }\end{array}$ \\
\hline & $\begin{array}{l}\text { Community development: project plannin } \\
\text { and group facilitation }\end{array}$ & & grants, transport, training, field allowances & & \\
\hline & $\begin{array}{l}\text { Vocational training for persons with } \\
\text { disabilities }\end{array}$ & & training, placement funds & & \\
\hline
\end{tabular}


Marginalized communities: improve

physical access, access to markets, access

to social services

\begin{tabular}{|l|l|l|}
\hline & & \\
\hline
\end{tabular}




\begin{tabular}{|c|c|c|c|c|c|}
\hline \multicolumn{6}{|c|}{ Logical Framework Matrix for Kenya's Economic Recovery Strategy for Wealth and Employment Generation (ERS) } \\
\hline \multicolumn{6}{|c|}{\begin{tabular}{|l|l|l|} 
PART C.1: GOVERNANCE Safety, Law and Order & & \\
\end{tabular}} \\
\hline \multicolumn{2}{|r|}{ Narrative } & & \multirow{2}{*}{\begin{tabular}{|l|} 
Indicators \\
from ....to....by (date) \\
\end{tabular}} & \multirow{2}{*}{\begin{tabular}{|l|} 
M\&E \\
data source and responsibility \\
\end{tabular}} & \multirow[t]{2}{*}{ Assumptions/Risks } \\
\hline & & & & & \\
\hline \multicolumn{6}{|c|}{ Objective } \\
\hline & Improved Governance & & $\begin{array}{l}\text { Control of corruption and rule of law: } \\
\text { proportion of corruption cases leading to } \\
\text { conviction increased }\end{array}$ & $\begin{array}{l}\text { Criminal Investigation } \\
\text { Department }\end{array}$ & \\
\hline \multicolumn{6}{|c|}{ Development Outcomes } \\
\hline & Public safety, law and order & & & & \\
\hline & $\begin{array}{l}\text { Strengthened justice and rule of law/ } \\
\text { achieving predictable and impartial justic } \\
\text { system }\end{array}$ & & $\begin{array}{l}\text { Increased ratio of concluded cases to } \\
\text { reported criminal cases from } 21 \% \text { in } 1999 \\
\text { to } 60 \% \text { in } 2006\end{array}$ & $\begin{array}{l}\text { Criminal Investigation } \\
\text { 9epartment, Statistical Abstract } \\
\text { (CBS) }\end{array}$ & \\
\hline & \begin{tabular}{|l|l|} 
Improved security &
\end{tabular} & & $\begin{array}{l}\text { Reduced number of criminal offences } \\
\text { from } 63,000 \text { in } 2001 \text { to } 35,000 \text { in } 2006\end{array}$ & $\begin{array}{l}\text { Criminal Investigation } \\
\text { Department, Statistical Abstract } \\
\text { (CBS) }\end{array}$ & \\
\hline \multicolumn{6}{|c|}{ Outputs } \\
\hline & Public safety, law and order & & & & \\
\hline fere & New constitution approved & & New constitution in place by June 2004 & Gazette notice & \\
\hline (8) & Security force strengthened & & $\begin{array}{l}\text { Number of trained and deployed in the } \\
\text { policeforce }\end{array}$ & $\begin{array}{l}\text { Police Dept/Office of the } \\
\text { President }\end{array}$ & \\
\hline & Corruption cases prosecuted & & Completed Goldenberg investigation & $\begin{array}{l}\text { MoJ, Anti-Corruption } \\
\text { Commission }\end{array}$ & \\
\hline$\theta$ & & & Corrupt judges replaced & $\begin{array}{l}\text { MoJ, Anti-Corruption } \\
\text { Commission }\end{array}$ & \\
\hline 7 & & & $\begin{array}{l}\text { Grabbed land and public housing } \\
\text { repossessed }\end{array}$ & $\begin{array}{l}\text { MoJ, Anti-Corruption } \\
\text { Commission }\end{array}$ & \\
\hline$B$ & & & $\begin{array}{l}\text { Corrupt contractors banned from public } \\
\text { contracting }\end{array}$ & $\begin{array}{l}\text { MoJ, Anti-Corruption } \\
\text { Commission }\end{array}$ & \\
\hline Fis & & & $\begin{array}{l}\text { Number of civil service prosecuted in } \\
\text { corruption ralated cases in 2003-2006 }\end{array}$ & $\begin{array}{l}\text { MoJ, Anti-Corruption } \\
\text { Commission }\end{array}$ & \\
\hline & $\begin{array}{l}\text { Reduced average time taken from filing to } \\
\text { disposal of cases from } 5 \text { years to } 2 \text { in high } \\
\text { court years and in magistrate courts from } \\
\text { to } 1\end{array}$ & & $\begin{array}{l}\text { Ratio of cases awaiting trial/reported case } \\
\text { reduced from } 75 \% \text { in } 1999 \text { to } 50 \% \text { in } 200\end{array}$ & $\begin{array}{l}\text { Criminal Investigation } \\
\text { Department, Statistical Abstract } \\
\text { (CBS) }\end{array}$ & \\
\hline & \begin{tabular}{|l|}
$\begin{array}{l}\text { Computerized registries for Justice } \\
\text { institutions. }\end{array}$ \\
\end{tabular} & & Registries installed by 2004 & MoJ progress reports & \\
\hline \multicolumn{6}{|c|}{ (s) } \\
\hline & Reduced congestion in the prisons & & Number of inmates per cell reduced & OVP\&MHA & \\
\hline \multicolumn{2}{|r|}{ Activities/Policies } & \begin{tabular}{|l|} 
Implementi \\
ng Agency
\end{tabular} & Inputs & & \\
\hline \multicolumn{6}{|c|}{ Public safety, law and order } \\
\hline & Constitutional review & GoK & & & $\begin{array}{l}\text { Parliament reviews and approves } \\
\text { constitutional draft }\end{array}$ \\
\hline & Complete constitutional review & MoJ & A new constitution developed & & \\
\hline & Review and harmonize laws & AG & & & \\
\hline \multicolumn{6}{|c|}{ Disseminate } \\
\hline & Police reforms & $\begin{array}{l}\text { OOP, } \\
\text { MHA, }\end{array}$ & & & \\
\hline & $\begin{array}{l}\text { Hire additional security staff to start } \\
\text { closing the gap with international/UN } \\
\text { standards. }\end{array}$ & & $\begin{array}{l}\text { New wages implemented in January } 2004 \\
\text { Hiring ongoing to meet the ratio }\end{array}$ & & \\
\hline & $\begin{array}{l}\text { Retrain, reequip and redeploy police force } \\
\text { and other security services }\end{array}$ & OOP & $\begin{array}{l}\text { Train, procure equipment and redeploy } \\
\text { security parsonnel }\end{array}$ & & \\
\hline \multicolumn{6}{|c|}{$\begin{array}{l}\text { Strengthen partnerships between the } \\
\text { police force and the private sector security } \\
\text { agencies }\end{array}$} \\
\hline & Computerize police department & & Equipment and training & & \\
\hline & $\begin{array}{l}\text { Complete stalled housing projects for } \\
\text { security staff. }\end{array}$ & & $\begin{array}{l}\text { Number of houses completed and } \\
\text { occupied by security personnel }\end{array}$ & Public Works & \\
\hline & $\begin{array}{l}\text { Strengthen specialized anti-banditry units } \\
\text { a tourism police unit, anti-terrorism police } \\
\text { units, port patrol units, and community } \\
\text { policing initiatives and anti-corruption } \\
\text { units. }\end{array}$ & & $\begin{array}{l}\text { Number of units established and police } \\
\text { recruited and deployed in the specialised } \\
\text { units }\end{array}$ & & \\
\hline
\end{tabular}




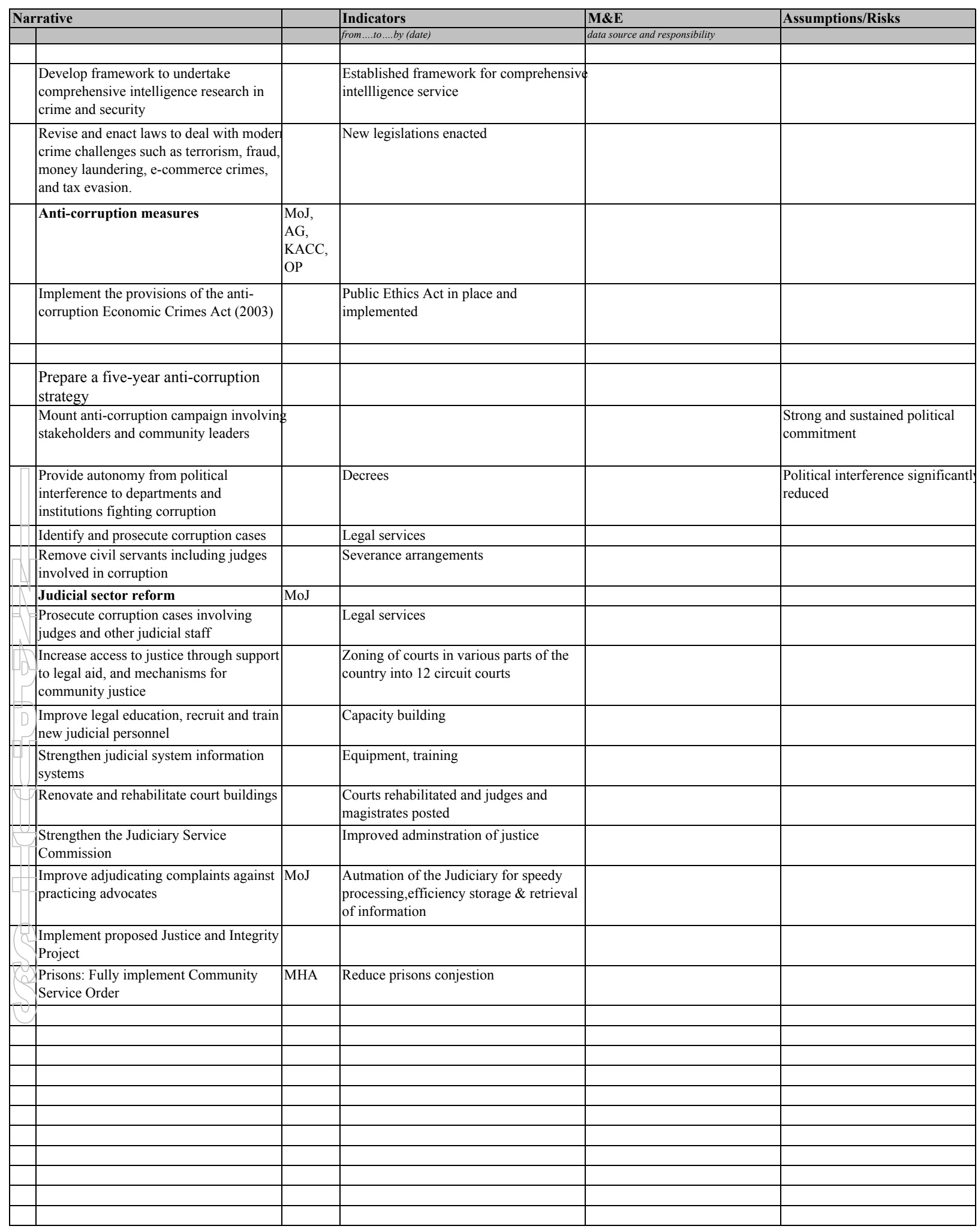




\begin{tabular}{|c|c|c|c|c|c|}
\hline \multicolumn{6}{|c|}{ Logical Framework Matrix for Kenya's Economic Recovery Strategy for Wealth and Employment Generation (ERS) } \\
\hline \multicolumn{6}{|c|}{\begin{tabular}{|l|l|l|} 
PART C.2: GOVERNANCE Public Administration & & \\
\end{tabular}} \\
\hline \multicolumn{2}{|r|}{\begin{tabular}{l|l} 
Narrative & \\
\end{tabular}} & & \multirow{2}{*}{\begin{tabular}{|l|} 
Indicators \\
from ...to....by (date) \\
\end{tabular}} & \multirow{2}{*}{\begin{tabular}{|l|}
$\mathbf{M} \& \mathbf{E}$ \\
data source and responsibility \\
\end{tabular}} & \multirow[t]{2}{*}{ Assumptions/Risks } \\
\hline & & & & & \\
\hline \multicolumn{6}{|c|}{ Objective } \\
\hline & Improved Governance & & $\begin{array}{l}\text { Improve transparency and accountability } \\
\text { of public administration }\end{array}$ & & \\
\hline \multicolumn{6}{|c|}{ Development Outcomes } \\
\hline \multirow[t]{5}{*}{2} & \multicolumn{5}{|c|}{ Public Sector Transparency and Devolution of Power } \\
\hline & $\begin{array}{l}\text { Fiscal resources released forallocation to } \\
\text { priority programs }\end{array}$ & & $\begin{array}{l}\text { Wage Bill/GDP reduced to } 8.5 \% \text { of GDP } \\
\text { by } 2005 / 06\end{array}$ & Budget Outturn, Treasury & civil service reforms successful \\
\hline & & & $\begin{array}{l}\text { Fiscal transfers to parastatals reduced by } \\
40 \% \text { by } 2006 / 07\end{array}$ & Budget - MoF & Parastatal reforms successful \\
\hline & Empowerment of communities & & $\begin{array}{l}\text { Proportion of budgetary resources } \\
\text { controlled by local governments increased }\end{array}$ & Budget - MoF & $\begin{array}{l}\text { fiscal discentralization } \\
\text { undertaken }\end{array}$ \\
\hline & & & $\begin{array}{l}\text { Communities report having greater controt } \\
\text { on local development resources }\end{array}$ & $\begin{array}{l}\text { Participatory assessments e.g. } \\
\text { score cards }\end{array}$ & $\begin{array}{l}\text { fiscal discentralization } \\
\text { undertaken }\end{array}$ \\
\hline \multicolumn{6}{|c|}{ Outputs } \\
\hline $2 \mid 1$ & \multicolumn{5}{|c|}{ Public Sector Transparency and Devolution of Power } \\
\hline (0) & Size of the civil service rationalized & & civil service reduced by 2008 & $\begin{array}{l}\text { IPPD/Directorate of Personnel } \\
\text { Management }\end{array}$ & $\begin{array}{l}\text { resources to undertake the } \\
\text { execise and political will }\end{array}$ \\
\hline (U) & $\begin{array}{l}\text { Improved incentive structure for civil } \\
\text { service employees }\end{array}$ & & $\begin{array}{l}\text { New salary structure in place. New } \\
\text { promotion policy approved }\end{array}$ & $\begin{array}{l}\text { IPPD/Directorate of Personnel } \\
\text { Management }\end{array}$ & $\begin{array}{l}\text { retrenchment leads to savings for } \\
\text { the exchequer }\end{array}$ \\
\hline 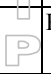 & Rationalized structure of parastatals & & Number of parastatals reduced & $\begin{array}{l}\text { Privitization commission Report, } \\
\text { MoF }\end{array}$ & Political will \\
\hline $\operatorname{lin}_{10}$ & Greater fiscal decentralization & & $\begin{array}{l}\text { Proportion of fiscal resources managed by } \\
\text { the decentralized administration as a \% of } \\
\text { total government spending increased }\end{array}$ & Budget $(\mathrm{MoF})$ & fiscal decentralization successful \\
\hline \multicolumn{2}{|c|}{ Activities/Policies } & $\begin{array}{l}\text { Implementi } \\
\text { ng Agency }\end{array}$ & Inputs & & \\
\hline \multicolumn{6}{|c|}{ Public Sector Transparency and Devolution of Power } \\
\hline & \begin{tabular}{|l|} 
Civil Service Reform \\
\end{tabular} & \begin{tabular}{|l|l|}
$\mathrm{OP}$ & \\
\end{tabular} & & & \\
\hline & $\begin{array}{l}\text { Establish target and reforms for achieving } \\
\text { a sustainable wage bill }\end{array}$ & MoF & & & \\
\hline & $\begin{array}{l}\text { Implement rationalization and } \\
\text { retrenchment of civil servants to reduce } \\
\text { wage bill/GDP ratio to level agreed with } \\
\text { MoF }\end{array}$ & $\begin{array}{l}\mathrm{MoF} / \\
\mathrm{DPM}\end{array}$ & $\begin{array}{l}\text { Reduce the number of civil service by } \\
2007 / 08\end{array}$ & $\begin{array}{l}\text { Increased allocation to productiv } \\
\text { sectors and Infrastructure, } \\
\text { Treasury }\end{array}$ & $\begin{array}{l}2000 \text { civil servants leave through } \\
\text { natural attrition ever year, freeze } \\
\text { on recruitment continues apart } \\
\text { from the critical areas. }\end{array}$ \\
\hline & $\begin{array}{l}\text { Undertake job evaluation exercise as the } \\
\text { basis for regrading and establishing salary } \\
\text { structure for the civil service }\end{array}$ & DPM & Job evaluation carried out by 2005 & Evaluation report - DPM & $\begin{array}{l}\text { Capacity to undertake the } \\
\text { evaluation }\end{array}$ \\
\hline & $\begin{array}{l}\text { Develop new policy of pay and benefits } \\
\text { for civil servants with emphasis on } \\
\text { performance-based advancement and } \\
\text { accelerate implementation of IPPD }\end{array}$ & DPM & $\begin{array}{l}\text { Permanent Pay and Review Board in plac } \\
\text { by } 2004 \text {, and New Policy on Pay and } \\
\text { Benefit approved by end of } 2005 .\end{array}$ & $\begin{array}{l}\text { Terms of Reference for the Board } \\
\text { and policy document, - DPM }\end{array}$ & $\begin{array}{l}\text { No capacity constraint within the } \\
\text { government. }\end{array}$ \\
\hline & $\begin{array}{l}\text { Develop training and capacity-building } \\
\text { policy }\end{array}$ & DPM & Policy developed and approved by 2005 & Policy document - DPM & \\
\hline & $\begin{array}{l}\text { Produce and implement ministerial } \\
\text { strategic plans and service delivery } \\
\text { benchmarking exercises }\end{array}$ & $\begin{array}{l}\mathrm{DPM} / \text { all } \\
\text { ministrie } \\
\mathrm{s}\end{array}$ & $\begin{array}{l}\text { Ministerial strategic plans in place by mid } \\
2004 \text { and service delivery benchmarks } \\
\text { developed by } 2004\end{array}$ & Strategic Plans, DPM & $\begin{array}{l}\text { The strategic plans will be } \\
\text { implemented and there is no } \\
\text { capacity constraint }\end{array}$ \\
\hline \multicolumn{6}{|c|}{\begin{tabular}{|l|l|} 
Public expenditure systems & \\
\end{tabular}} \\
\hline \multicolumn{6}{|c|}{$\begin{array}{l}\text { See Public ex[penditure reforms in Matrix Mo } \\
\text { A. } 1\end{array}$} \\
\hline \multicolumn{6}{|c|}{\begin{tabular}{|l|l|} 
Parastatal reform & \\
\end{tabular}} \\
\hline & $\begin{array}{l}\text { Finalize plan to restructure the } 136 \\
\text { existing state corporations and statutory } \\
\text { boards, including rationalization, } \\
\text { restructuring, mergers and legislative } \\
\text { reforms, and submit to the Cabinet for } \\
\text { approval and implementation. }\end{array}$ & $\mathrm{MoF}$ & $\begin{array}{l}\text { Privitization bill passed and the } \\
\text { Privitization commission formed by end } \\
2003\end{array}$ & $\begin{array}{l}\text { Privatization bill and the } \\
\text { Privitization commission (AG } \\
\text { chambers and MoF). }\end{array}$ & $\begin{array}{l}\text { Strong and sustained political } \\
\text { commitment. }\end{array}$ \\
\hline
\end{tabular}




\begin{tabular}{|c|c|c|c|c|c|}
\hline \multicolumn{2}{|c|}{ Narrative } & & \multirow{2}{*}{\begin{tabular}{|l|} 
Indicators \\
from....to....by (date) \\
\end{tabular}} & \multirow{2}{*}{\begin{tabular}{|l|}
$\mathbf{M} \& \mathbf{E}$ \\
data source and responsibility \\
\end{tabular}} & \multirow[t]{2}{*}{ Assumptions/Risks } \\
\hline & & & & & \\
\hline$\square$ & Local government reforms & $\begin{array}{l}\text { MoF, } \\
\text { MLG }\end{array}$ & & & \\
\hline & $\begin{array}{l}\text { Develop national policy on } \\
\text { decentralization consistent with } \\
\text { constitutional reform, and review Local } \\
\text { Authority Act }\end{array}$ & MoLG & $\begin{array}{l}\text { National policy on decentralization in } \\
\text { place by } 2005 \text { and the LA Act reviewed b } \\
2005\end{array}$ & $\begin{array}{l}\text { Policy document and the } \\
\text { Reviewed local authority Act, } \\
\text { (MoLG and the AG Chambers) }\end{array}$ & no political interferance. \\
\hline $\begin{array}{l}D \\
5\end{array}$ & \begin{tabular}{|l|} 
Deepen local government reforms \\
including operationalizing Kenya Local \\
Government Reform Programme \\
(KLGRP) by implementing the local \\
authority service delivery action plan and \\
establishing an integrated financial \\
management information system, and staff \\
rationalization
\end{tabular} & MoLG & $\begin{array}{l}\text { LA Service delivery plan implemented } \\
\text { from 2005, IFMIS functionsl from } 29005\end{array}$ & $\begin{array}{l}\text { Audit and Controller General } \\
\text { Report - AG }\end{array}$ & Political will and capacity \\
\hline & $\begin{array}{l}\text { Review fiscal decentralization modalities } \\
\text { establish single disbursement system to } \\
\text { the localities and system of performance- } \\
\text { based rewards and punishments }\end{array}$ & MoF & $\begin{array}{l}\text { Legal services to revise Local Governmen } \\
\text { Act }\end{array}$ & $\begin{array}{l}\text { New LA Act and reviewed fiscal } \\
\text { decentralization modalities, } \mathrm{MoF}\end{array}$ & Political goodwill \\
\hline$(8$ & $\begin{array}{l}\text { Strengthen M\&E and vertical reporting } \\
\text { requirements to monitor local government } \\
\text { programs }\end{array}$ & & $\begin{array}{l}\text { M\$E capacity built, annual audits } \\
\text { undertaken. }\end{array}$ & $\begin{array}{l}\text { Account (local governments), } \\
\text { audits (General Comptroller) }\end{array}$ & $\begin{array}{l}\text { no human capacity constraint and } \\
\text { M\$E capacity is utilised }\end{array}$ \\
\hline
\end{tabular}




\begin{tabular}{|c|c|c|c|c|c|}
\hline Log & gical Framework Matrix for Ke & enya's E & Economic Recovery Strategy for & Wealth and Employmen & nt Generation (ERS) \\
\hline PA & RT C.3: GOVERNANCE Mon & itoring & and Evaluation & & \\
\hline Nar & \begin{tabular}{l|l} 
rative \\
\end{tabular} & & Indicators & M\&E & Assumptions/Risks \\
\hline & & & from....to....by (date) & data source and responsibility & \\
\hline Obj & ective & & & & \\
\hline & Improved Governance & & Government effectiveness (MDG12) & $\begin{array}{l}\text { Governance Survey, KIHBS, } \\
\text { CWIQ (CBS) }\end{array}$ & $\begin{array}{l}\text { Reliable GoK and Donor cash } \\
\text { flow }\end{array}$ \\
\hline Dev & elopment Outcomes & & & & \\
\hline DT & & & & & \\
\hline V7 & Improved data quality & & $\begin{array}{l}\text { Survey questionnaires modified by June } \\
\text { 2004; discrepancy between survey and } \\
\text { administrative data reduced by } 2005 \text {. }\end{array}$ & Independent assessment & $\begin{array}{l}\text { Board approval of STATCAP } \\
\text { Master Plan }\end{array}$ \\
\hline & Expanded access to information & & Dissemination mechanisms in place & Research, reports & \\
\hline (ए) & Strengthened policy analysis & & $\begin{array}{l}\text { Number and quality of studies completed } \\
\text { in priority areas of the National Research } \\
\text { Agenda }\end{array}$ & Progress reports, peer reviews & Funds for capacity building \\
\hline$\sqrt{2}$ & $\begin{array}{l}\text { M\&E feedback improves budgetary } \\
\text { allocations }\end{array}$ & & $\begin{array}{l}\text { Budget savings from reforms; budget } \\
\text { allocations in ERS priority programs }\end{array}$ & PER & \\
\hline 8 & & & & & \\
\hline Out & puts & & & & \\
\hline & & & & & \\
\hline 10 & Institutional framework for $\mathrm{M} \& \mathrm{E}$ in place & & $\begin{array}{l}\text { NESC and Executive Secretariat, MEC } \\
\text { established and staffed by December } 2003\end{array}$ & Decree; Budget & $\begin{array}{l}\text { Adequate GoK and donor } \\
\text { budgetary support }\end{array}$ \\
\hline 2 & Statistical Strategic Plan implemented & & Implementation plan ready by March 200 & 4Progress reports & Board approval of STATCAP M \\
\hline 3 & Integrated data management system & & $\begin{array}{l}\text { System designed and installed by June } \\
2004\end{array}$ & $\begin{array}{l}\text { Consultant reports; procurement } \\
\text { records; functional IDMS }\end{array}$ & Establishment of inter-ministerial \\
\hline & & & $\begin{array}{l}\text { MIS operational in key ministries (MoE, } \\
\text { MoH, MRPW, MLD) by } 2004\end{array}$ & $\begin{array}{l}\text { Implementation reports (MoE, } \\
\text { MoH, MRPS, MLS) }\end{array}$ & \\
\hline 4 & National research agenda & & $\begin{array}{l}\text { National Research Agenda approved by } \\
\text { Jan } 2004\end{array}$ & Publication & $\begin{array}{l}\text { Continued collaboration with } \\
\text { local research institutions }\end{array}$ \\
\hline (j) & $\begin{array}{l}\text { Interinstitutional protocol for } \\
\text { budget/MTEF/M\&E linkage }\end{array}$ & & MoP/MoF protocol approved by Dec 200 & BDecree & $\begin{array}{l}\text { MoF implements result-based } \\
\text { budget reforms, OP civil service } \\
\text { reforms }\end{array}$ \\
\hline 6 & $\begin{array}{l}\text { Government institutions that received } \\
\text { training on } \mathrm{M} \& \mathrm{E}\end{array}$ & & $\begin{array}{l}\text { Number of government staff that received } \\
\text { training on M\&E }\end{array}$ & Training records & \\
\hline 7 & Public information access policy & & Policy approved by June 2004 & Gazette/decree & \\
\hline S & $\begin{array}{l}\text { Memorandum of Understanding with } \\
\text { NGO community }\end{array}$ & & $\begin{array}{l}\text { NGO MoU negotiated and approved by } \\
\text { June } 2004\end{array}$ & Publication & $\begin{array}{l}\text { continued favourable climate for } \\
\text { continued private sector } \\
\text { participation }\end{array}$ \\
\hline Hot & & & & & \\
\hline Acti & ivities/Policies & \begin{tabular}{|l|}
$\begin{array}{l}\text { Implementi } \\
\text { ng Agency }\end{array}$ \\
\end{tabular} & Inputs & & \\
\hline & & & & & \\
\hline & $\begin{array}{l}\text { Develop institutional framework for } \\
\text { M\&E, including a National Economic and } \\
\text { Social Council and an executive } \\
\text { secretariat }\end{array}$ & MoP & Action plan & Progress reports & \\
\hline 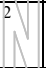 & Implement Statistical Strategic Plan & CBS & $\begin{array}{l}\text { Consultancy services, Technical assistanc } \\
\text { missions, staff, equipment }\end{array}$ & Implementation reports (CBS) & $\begin{array}{l}\text { SP Bill passed; Board approval o } \\
\text { STATCAP Master Plan }\end{array}$ \\
\hline & $\begin{array}{l}\text { Install integrated data management systen } \\
\text { in CBS }\end{array}$ & CBS & Consulting services, training, equipment & $\begin{array}{l}\text { Implementation reports (CBS, } \\
\text { MoE, MoH, MRPW,MLS) }\end{array}$ & \\
\hline 4 & $\begin{array}{l}\text { Develop national research agenda in } \\
\text { consultation with academic and donor } \\
\text { communities }\end{array}$ & MoP & Consulting services & Report & \\
\hline U & $\begin{array}{l}\text { Develop inter-institutional framework to } \\
\text { ensure linkage between budget, MTEF } \\
\text { and M\&E }\end{array}$ & $\begin{array}{l}\mathrm{MoP} \\
\mathrm{MoF}\end{array}$ & & Decree & \\
\hline 6 & $\begin{array}{l}\text { Implement plan to institutionalize } \mathrm{M} \& \mathrm{E} \\
\text { across government }\end{array}$ & MoP & $\begin{array}{l}\text { training courses held workshops, } \\
\text { equipment procured }\end{array}$ & MoP reports & \\
\hline 7士 & $\begin{array}{l}\text { Design and approve public information } \\
\text { access policy }\end{array}$ & MoP & Consulting services & Draft bill & \\
\hline 8 & $\begin{array}{l}\text { Develop cooperation with NGOs to } \\
\text { support dissemination and feedback }\end{array}$ & MoP & & Memorandum of Understanding & \\
\hline & & & & & \\
\hline
\end{tabular}

